AFONSO LUÍS CORRÊA DE VIRGILIIS

PROCEDIMENTOS DE PROJETO E EXECUÇÃO DE PAVIMENTOS PERMEÁVEIS VISANDO RETENÇÃO E AMORTECIMENTO DE PICOS DE CHEIAS

São Paulo

2009 
AFONSO LUÍS CORRÊA DE VIRGILIIS

\section{PROCEDIMENTOS DE PROJETO E EXECUÇÃO DE PAVIMENTOS PERMEÁVEIS VISANDO RETENÇÃO E AMORTECIMENTO DE PICOS DE CHEIAS}

Dissertação apresentada à Escola Politécnica da Universidade de São Paulo para a obtenção do título de Mestre em Engenharia

Área de concentração:

Engenharia de Transportes

Orientador:

Prof. Dr. Carlos Yukio Suzuki

São Paulo

2009 
Este exemplar foi revisado e alterado em relação à versão original, sob responsabilidade única do autor e com a anuência de seu orientador.

São Paulo, de dezembro de 2009.

Assinatura do autor

Assinatura do orientador

FICHA CATALOGRÁFICA

Virgiliis, Afonso Luís Corrêa de

Procedimentos de projeto e execução de pavimentos per meáveis visando retenção e amortecimento de picos de cheias / A.L.C. Virgiliis. -- ed.rev. -- São Paulo, 2009. $191 \mathrm{p}$.

Dissertação (Mestrado) - Escola Politécnica da Universidade de São Paulo. Departamento de Engenharia de Transportes.

1. Pavimentação (Permeabilidade) 2. Asfalto (Permeabilidade)

3. Blocos (Permeabilidade) I. Universidade de São Paulo. Escola Politécnica. Departamento de Engenharia de Transportes II. t. 
Ao Eng.ํㅡㄹ Ernani Virgiliis, meu pai, Meu incentivo, meu exemplo e admiração.

Ao Sr. Antônio Salomão,

Pela bravura, integridade e luta. 


\section{AGRADECIMENTOS}

Ao Prof. Dr. Carlos Yukio Suzuki, pela orientação em todo o trabalho, cuja presteza e paciência foram fundamentais ao meu aprimoramento, sempre disposto a ajudar mesmo quando muito ocupado. Muitíssimo obrigado.

Ao Prof. Dr. José Rodolfo Scarati Martins, pelo incentivo e palavras de encorajamento, por nunca deixar de acreditar em mim sempre me ajudando a enxergar a luz no fim do túnel.

A Prof. Drª Liedi Bariani Bernucci, que esteve presente e lutando para a realização desta jornada.

Aos amigos Ricardo e Fátima Curi que sem dúvida representam muito para mim. Apoiando-me em todos os momentos. Não vou me esquecer de vocês.

Ao Secretário Adjunto da Secretaria de Infraestrutura Urbana e Obras -SIURB, Eng.‥ Marcos Rodrigues Penido, um amigo sempre presente e com soluções geniais para os obstáculos que pareciam intransponíveis, sem sua ajuda o presente trabalho não sairia do papel. Pelo seu entusiasmo, pela tranqüilidade e por toda a gentileza, obrigado.

Ao Eng.. Rossi do Lions Sumaré por tanto empenho e ajuda.

Ao Prefeito de São Paulo, Eng. Gilberto Kassab, por ver na idéia um futuro para nossa cidade tão grande e complexa.

Ao amigo Humberto Nascimento, que com seu conhecimento prático e entusiasmo inabalável, contribuiu muito com suas sugestões.

Ao Walter de Souza Faria responsável pela usina de asfalto, com quem primeiro conversei sobre a idéia de pavimentos permeáveis me incentivando a trabalhar com esse assunto e permanecendo comigo nessa empreitada. 
Ao Dr. Ricardo Borsari meus agradecimentos pela visão empreendedora e colaborativa e a todos do DAEE que acompanharam o desenvolvimento das obras.

Aos colegas Vera Melo, Jorge Ogata, Dirce C. Balzan, Fernando Vilar Lemos, Flávio Vechiatto Galletti, Laerte Moroni Pires e Zaira, todos da SIURB e membros da Comissão de Normas de Pavimentação da PMSP, dia a dia envolvidos e interessados pelo desenvolvimento do trabalho.

Ao caro amigo Flavio Conde e sua equipe do SAISP, Cícera Lemos, Cristiane Andrioli , Kleber e outros amigos pelo suporte, caronas e conselhos.

Ao Prof. Dr. Augusto Pereira Filho do IAG - USP que pode abrir novos horizontes nunca trilhados por mim, obrigado.

A Eng ${ }^{a}$ Liliane Lopes Pinto pelas horas de trabalho e paciência realizando cálculos e revendo detalhes do projeto e sua execução.

Aos amigos Eng. a Sandra Uemura e Eng. Rodrigo da Hidráulica Computacional, que tanto ajudaram.

Ao Eng.. Pedro Algodoal, pelas horas que passamos discutindo o assunto, propondo soluções e comentando alternativas.

Ao Anderson Nakazone, meu fiel escudeiro, Rosângela Motta, Diomária e Edson Moura do Laboratório de Tecnologia de Pavimentação LTP-EPUSP.

Aos Professores Doutores, Luís César Souza Pinto, Felipe Domingues, Mario Thadeu Leme de Barros, José Tadeu Balbo, e Ruben La Laina Porto, sempre cumprindo a louvável missão de ensinar, e a tudo que me ensinaram muito bem, grato.

Ao Prof. Dr. Kamel Zahed Filho, que certa vez jogou minha vaquinha pelo precipício, mesmo sem querer, impulsionando minha determinação de persistir e ir adiante. 
A Profáa. Dra . Mônica Porto cujo empenho como presidente da FCTH permitiu a construção da pista experimental.

A Arquiteta Amanda Cristina Franco pelas palavras de incentivo e encorajamento quando estávamos à frente da Subprefeitura.

Aos colegas engenheiros, Carmen Silvia Facioli e Roberto Costa por me aturarem quando eu estava na Coordenadoria de Projetos e Obras da SP-PI.

As queridas amigas Inês Ferraz de Campos, Sônia Belintani de Souza, Luciana Gomes Mendes, Regina Prete e ao amigo Catarino Rodrigues pela torcida.

Ao Eng.. Marcelo Missato pela grande ajuda com os desenhos e desenvolvimento do projeto geométrico em CAD.

Ao Prof. Dr. Carlos M. Tucci que me recebeu em Porto Alegre no Instituto de Pesquisas Hidráulicas IPH para meu primeiro contato com o experimento de pavimentos permeáveis da Eng. a e Mestre Laura Acioli e ao Prof. Dr. Marcio Baptista que esteve em SIURB para um curso de drenagem e enviou um precioso material para estudo de casos de pavimentos drenantes realizados na França.

Meus colegas Reynaldo Cagnin, Homero e Mozart Corrêa que agüentaram a pressão e ainda tem fôlego para agüentar mais.

A todos da Secretaria do Verde e Meio Ambiente, Secretário Eduardo Jorge, Dr. Wolf Steinbaun e Eng. ${ }^{\circ}$ Eduardo Aulicino que ouviram sobre pavimentos permeáveis nas nossas reuniões do Comitê de Mudanças Climáticas e Eco-economia Sustentável.

Ao Prof. Dr. Carlos Eduardo Tomanik Packer, meu amigo e conselheiro, que Deus o tenha na lembrança.

Ao Eng ${ }^{\circ}$ Agrônomo Marcos Garcia Ortega, pela grande ajuda no desenvolvimento do projeto de compensação ambiental junto a Secretaria do Verde e Meio Ambiente. 
Ao Engo Fernando Augusto Junior da IMPERPAV e sua equipe, pelo profissionalismo e amizade, sempre dispostos e atentos a cada detalhe, contribuindo com importantes informações.

A Simone e Maya além de toda equipe da PLANSERVI, a todos da FBS e ao corpo técnico e pesquisadores do LTP - Laboratório de Tecnologia de Pavimentação, ao CTH - Centro Tecnológico de Hidráulica e seus profissionais que tanto colaboraram, a Escola Politécnica da Universidade de São Paulo e a Prefeitura da Cidade de São Paulo que percebeu neste projeto, um alívio para muitos paulistanos que padecem todo ano com problemas de enchentes e alagamentos.

Finalmente, jamais poderei me esquecer de minha esposa Mônica que se privou de muitas coisas sempre compreensiva e de todo apoiadora, ajudando-me com sua expressão "não vai desistir agora!" dando-me forças para prosseguir até o fim. Tenho certeza que você sabe muito sobre pavimentos permeáveis de tanto me ouvir falar.

A Deus acima de tudo e de todos. 


\section{RESUMO}

O trabalho tem por objetivo apresentar procedimentos de projeto e execução de obras de pavimentos permeáveis visando sua aplicação prática como medidas compensatórias de drenagem urbana com a finalidade de retenção e amortecimento de picos de enchentes em cidades densamente urbanizadas. Os procedimentos propostos se baseiam na experiência adquirida para a implementação de dois tipos de pavimentos permeáveis; um com revestimento constituído de blocos intertravados de concreto e outro com revestimento de concreto asfáltico poroso, conhecido como camada porosa de atrito. Para subsidiar o trabalho uma pista experimental foi construída como área de estacionamento nas dependências do Centro Tecnológico de Hidráulica - CTH na Universidade de São Paulo onde foi realizado o experimento. O local do estacionamento atua como um reservatório subsuperficial de águas pluviais sendo que sua estrutura, constituída de agregados granulares, abriga no interior de seus vazios a água infiltrada pelas camadas do pavimento. Recomenda-se, após os estudos, que os procedimentos e seqüências de atividades de projeto e execução de obras de pavimentos permeáveis sejam contemplados pelo poder público e privado como solução alternativa em diferentes empreendimentos urbanos como grandes áreas públicas ou particulares, estacionamentos, parques, quadras esportivas, passeios, calçamentos e ruas de pouca solicitação de tráfego entre outros.

Palavras-chave: Blocos intertravados. Concreto asfáltico poroso. Pavimento permeável; Camadas drenantes. 


\begin{abstract}
The present work intents to show design and built procedures, of porous pavements; by paying attention on its practical appliances as compensatory option in urban drainage with purpose to retaining rainfall water by storage, reducing downstream flooding in cities with great urban density. The procedures here proposed are based in the know how acquired for the construction of two kinds of porous pavements: one built with interlocked concrete blocks and the other built with porous asphalt. In order to aid the present work, an experimental field was built as parking area inside the propriety of CTH - Centro Tecnologico de Hidraulica in State University of Sao Paulo where the tests and experiments were made. The parking area is a reservoir structure where rain water is stored inside courses of aggregates. The storage volume is in the void space between particles of material that comes by infiltration trough the pavement layer. The commendation, after the studies, is that procedures and activities of design and build of porous pavements could be observed by government and private sector as alternative solution in many kinds of urban projects such as large public and private lots, parking areas sport fields side walks and streets, with low capacity of traffic loads, and so forth.
\end{abstract}

Key words: Concrete blocks; Porous asphalt; Porous pavements; Porous structure; Drainage Courses. 


\section{LISTA DE ILUSTRAÇÕES}

Figura 1 - Efeitos da urbanização sobre o hidrograma da bacia. (adaptado de Cordeiro Netto,1994) 13

Figura 2 - Diferenças nos hidrogramas urbanos de montante e jusante com sistema estrutural de drenagem, SEMADS, 2001

Figura 3 - Esquema de reservatório de detenção (Tucci - ABRH, 2000). 18

Figura 4 - Perfil hidráulico do solo durante a infiltração ( fonte: Musy et al.,1991) ...19 Figura 5 - Diferentes fases de infiltração de um dispositivo de drenagem (Burgéap, 1991)

Figura 6 - Tipos de cobertura e área pavimentável em três categorias de uso (adaptado do apêndice D, Cappiella \& Brown, 2001)

Figura 7 - Exemplo de diferentes tipos de pavimento com reservatório estrutural (extraído de Azzout ET AL., 1994 e Acioli, L. A. UFRGS, 2003)...........................27

Figura 8 - Tipos de pavimentos permeáveis (adaptados de Schueler, 1987)...........29

Figura 9 - Pavimento com duas camadas sob o revestimento .................................34

Figura 10 - Sobrecamada porosa sobre revestimento convencional.........................35

Figura 11 - Pavimentos com reservatórios em nível ou inclinados (Fergunson

B.K.,2005).

Figura 12 - Exemplos de dispositivos de descarga lateral localizados na parte inferior do Reservatório de Base (Fergunson B.K., 2005).

Figura 13 - Exemplos de dispositivos de descarga lateral localizados na parte

superior do Reservatório de Base (Fergunson B.K., 2005).

Figura 14 - Exemplos de dispositivos que permitem o escoamento superficial e protegem o pavimento (Fergunson B.K., 2005).

Figura 15 - Aplicação de geotêxteis em pavimentos deformáveis (ABINT, 1999) ....41

Figura 16 - Aplicação de geotêxtil como separação e filtro (ABINT, 1999).

Figura 17 - Aplicação de geomembrana conjugada com geotêxtil em reservatórios (ABINT, 1999).

Figura 18 - Geocélulas plásticas (ABINT, 1999).

Figura 19 - Pavimento permeável com superfície de blocos porosos ou vazados (Febestral, 2005).

Figura 20 - Conceito de travamento pelas fibras dentro do ligante modificado com polímeros (Fergunson B. K.,2005) 
Figura 21 - Fluxograma de atividades de projeto ………................................

Figura 22 - Fluxograma para análise de viabilidade (L.A. Aciolli, 2005) ..................76

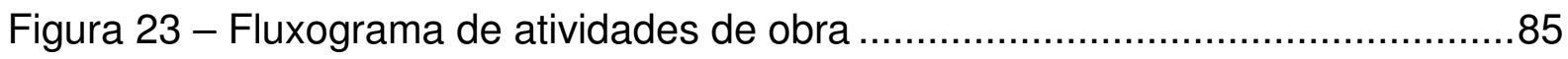

Figura 24 - Vista em planta do local do experimento. .........................................98

Figura 25 - Perfil do pavimento de Blocos Intertravados (sem escala)...................100

Figura 26 - Perfil do pavimento de CPA (sem escala) ........................................101

Figura 27 - Localização dos furos das sondagens ………………………....107

Figura 28 - Localização dos furos para classificação MCT das amostras ...............110

Figura 29 - Planta do levantamento planialtimétrico cadastral .............................114

Figura 30 - Projeto Geométrico (sem escala) ...............................................116

Figura 31 - Projeto Geométrico - Perfil transversal (s/escala) ...............................117

Figura 32 - Drenagem - Perfil longitudinal (s/escala) ......................................117

Figura 33 - Esquema elucidativo das camadas ………................................120

Figura 34 - Perfil da Área B - PPC -Blocos Intertravados de Concreto...................128

Figura 35 - Perfil da Área C - Concreto asfáltico poroso tipo CPA .......................128 


\section{LISTA DE FOTOGRAFIAS}

Foto 1 - Escoamento superficial em evento severo de precipitação - Fonte: Jornal O Estado de São Paulo 23/09/2003. 14

Foto 2 - Alagamento no bairro do Morumbi em São Paulo - Fonte: Jornal O Estado de São Paulo 23/09/2003 14

Foto 3 - Reservatório revestido com geomembrana (revista Engenharia edição 547, 2001). .42

Foto 4 - Blocos de concreto pré-moldado vazados .46

Foto 5 - Blocos de concreto intertravados assentados sobre berço de areia. .47

Foto 6 - Concreto Asfáltico Poroso .48

Foto 7 - Coleta de solo a 0,50, 1,00 e 1,50 metros de profundidade. 111

Foto 8 - Local do experimento - Antes do transplante das árvores. 130

Foto 9 - Preparação do torrão para o transplante. 131

Foto 10 - Remoção através de guindaste Munk.

Foto 11 - Local do experimento - Depois do transplante das árvores. 132

Foto 12 - Amostra de CPA e demonstração de sua permeabilidade. 133

Foto 13 - Limpeza do terreno 136

Foto 14 - Seqüência de fotos da abertura de caixa de pavimentação. 136

Foto 15 - Abertura de caixa de $45 \mathrm{~cm}$ de profundidade. 137

Foto 16 - Seqüência de fotos da preparação do aterro 137

Foto 17 - Seqüência de fotos compactação do aterro (área B) . 138

Foto 18 - Compactação do subleito. 138

Foto 19 - Espalhamento e nivelamento do solo de reforço 139

Foto 20 - Solos para reforço do sub leito 140

Foto 21 - Instalação da rede de drenagem. 141

Foto 22 - Coleta de amostras para ensaio de CBR 141

Foto 23 - Assentamento da geomembrana. 142

Foto 24 - Espalhamento da pedra 3 143

Foto 25 - Compactação das camadas de pedra 3 143

Foto 26 - Lançamento, espalhamento e compactação da BGS .............................144

Foto 27 - BGS e pedra 3 após compactação...................................................145

Foto 28 - Execução das guias e sarjetas. 
Foto 29 - Execução do macadame betuminoso 146

Foto 30 - Imprimadura ligante - macadame betuminoso 146

Foto 31 - Execução da camada porosa de atrito - CPA....................................147

Foto 32 - Assentamento da manta de geotêxtil ..............................................148

Foto 33 - Peças pré moldadas de concreto poroso - Assentamento .......................148

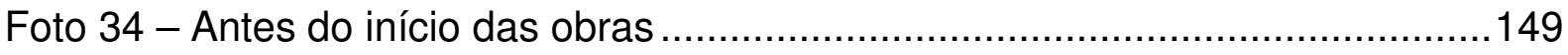

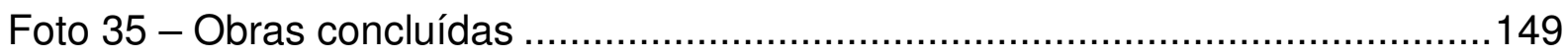




\section{LISTA DE TABELAS}

Tabela 1 - População mundial e projeção para 2030 (fonte: World Urbanization

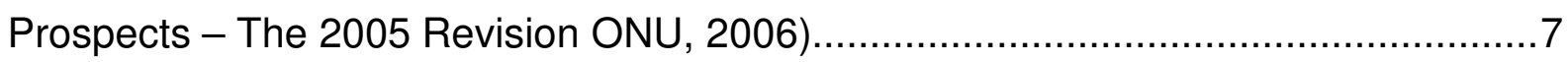

Tabela 2 - Terminologia geralmente aplicada a pavimentos porosos. ......................33

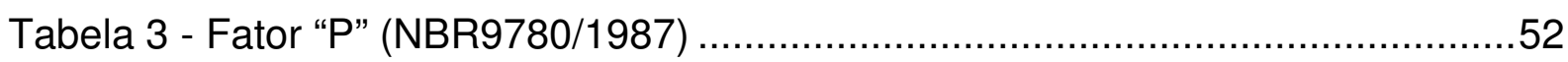

Tabela 4 - Perda de agregados no ensaio cântabro (\%) ........................................62

Tabela 5 - Vida à fadiga de diversas misturas porosas modificadas por polímeros. . 63

Tabela 6 - Valores de vida à fadiga (repetições) para misturas novas e envelhecidas.

Tabela 7 - Média e desvio padrão de máximas intensidades de chuva em mm/min 77

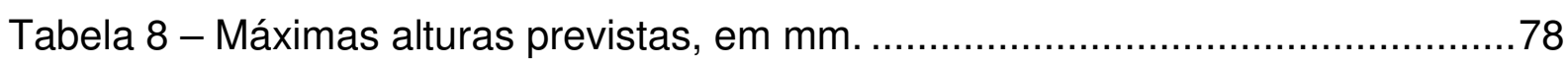

Tabela 9 - Densidade dos grãos ensaiados. …………..................................103

Tabela 10 - Valores de porosidade $n$ dos materiais das camadas ........................104

Tabela 11 - Resumo dos ensaios de caracterização...........................................108

Tabela 12 - Resumo dos ensaios de compactação e CBR …………...................108

Tabela 13 - Resultado da classificação MCT ...................................................111

Tabela 14 - Classificação das ruas quanto ao tipo de tráfego ................................118

Tabela 15 - Valores tabelados de dimensionamento.........................................119

Tabela 16 - Espessuras mínimas de revestimento -..........................................119

Tabela 17 - Coeficientes estruturais do revestimento........................................120

Tabela 18 - Especificações Técnicas de Materiais e Serviços ................................123

Tabela 19 - Dosagem da Camada Porosa de Atrito .............................................124

Tabela 20 - Granulometria CPA -Faixa Arizona.................................................125

Tabela 21 - Especificações do CPA - Faixa Arizona .........................................126

Tabela 22 - Ensaios de permeabilidade do CPA ……......................................133

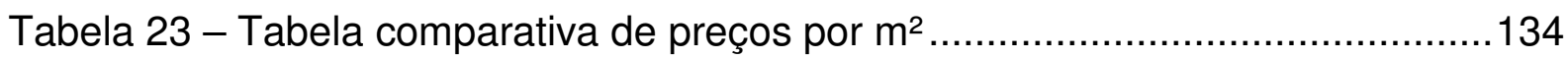




\section{LISTA DE GRÁFICOS}

Gráfico 1 - Evolução demográfica em áreas urbanas e rurais (Fonte: World Urbanization Prospects - The 2005 Revision ONU, 2006).

Gráfico 2 - Evolução demográfica no Brasil. (Fonte: World ONU Urbanization

Prospects - The 2006 Revision Population Database, 2007). .8

Gráfico 3 - Resistência do concreto em função do fator a/c ...................................54

Gráfico 4 - Resistência do concreto em função da idade ....................................54

Gráfico 5 - Faixa granulométrica clássica e nova adaptado de Thelen e Howe (1978).

Gráfico 6 - Ábaco de dimensionamento

Gráfico 7 - Espessuras necessárias de sub- base. 


\section{LISTA DE ABREVIATURAS E SIGLAS}

AASHTO - American Association of State Highways and Transportation Officials ABCP - Associação Brasileira de Cimento Portland

ABINT - Associação Brasileira de Não Tecidos

ABNT - Associação Brasileira de Normas Técnicas

ABRH - Associação Brasileira de Recursos Hídricos

ADP - Asfalto Diluído de Petróleo

BCA - British Cement Association

BDI - Bonificação de Despesas Indiretas

BGS - Brita Graduada Simples

BMP - Borracha Moída de Pneus

CAP - Cimento Asfáltico de Petróleo

CAUQ - Concreto Asfáltico Usinado a Quente

CBR - California Bearing Rate

CIRIA - Construction Industry Research and Information Association

CPA - Camada Porosa de Atrito

CTH - Centro Tecnológico de Hidráulica

DEPAVE - Departamento de Parques e Áreas Verdes

DERSA - Desenvolvimento Rodoviário S.A.

DNER - Departamento Nacional de Estradas de Rodagem

EPA - United States Environmental Protection Agency

EUA - Estados Unidos da América

EVA - Etileno-Acetato de Vinila

FCTH - Fundação Centro Tecnológico de Hidráulica

FHWA - U. S. Federal Highways Administration

GAP - Galeria de Águas Pluviais

IAG - Instituto Astronômico e Geofísico

IBGE - Instituto Brasileiro de Geografia e Estatística

IP - Índice de Plasticidade

LL - Limite de Liquidez

LP - Limite de Plasticidade

MB - Macadame Betuminoso 
MCT - Miniatura, Compactado, Tropical

MH - Macadame Hidráulico

$\mathrm{MPa}$ - Mega Pascal

N.A. - Nível d'água

NBR - Normas Brasileiras

ONU - Organização das Nações Unidas

PEAD - Polietileno de Alta Densidade

PMSP - Prefeitura do Município de São Paulo

PPC - Peças Pré-moldadas de Concreto

RDC - Resíduo de Construção Civil

SBR - Estireno-Butadieno-Borracha

SBS - Estireno-Butadieno-Estireno

SEMADS - Secretaria Estadual do Meio Ambiente e Desenvolvimento Social

SIURB - Secretaria de Infraestrutura Urbana e Obras

SVMA - Secretaria de Verde e Meio Ambiente

TCA - Termo de Compromisso Ambiental

USACE - U. S. Army Corps of Engineers

USP - Universidade de São Paulo 


\section{SUMÁRIO}

1. INTRODUÇÃO

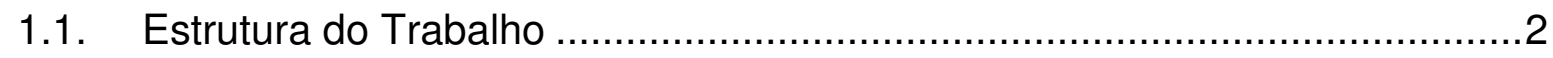

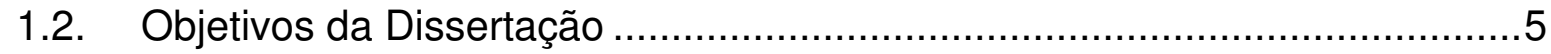

2. DRENAGEM URBANA - EVOLUÇÃO E PROBLEMAS DECORRENTES..........6

2.1. Sistemas de Drenagem Urbana ........................................................

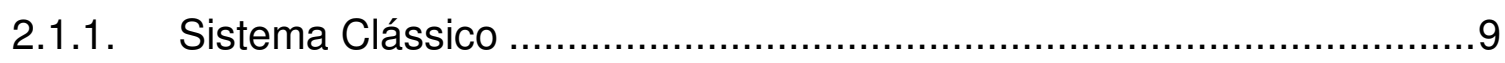

2.1.2. Sistema Alternativo ou Compensatório...............................................10

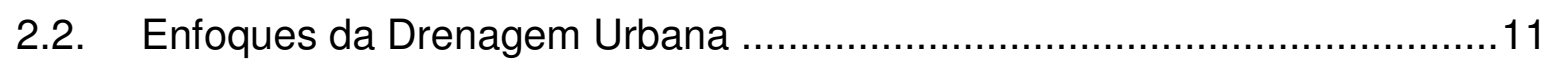

2.2.1. Condutividade Hidráulica Controlada.............................................11

2.2.2. Armazenamento das Águas.............................................................11

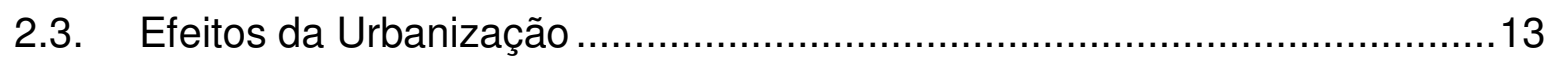

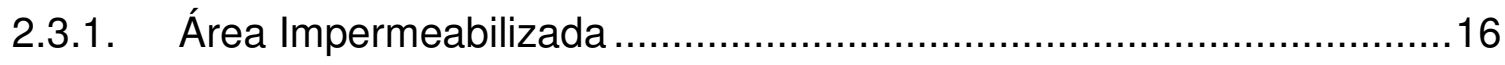

2.3.2. Dispositivos de Detenção e Amortecimento .......................................17

2.4. Dispositivos de Infiltração ..............................................................19

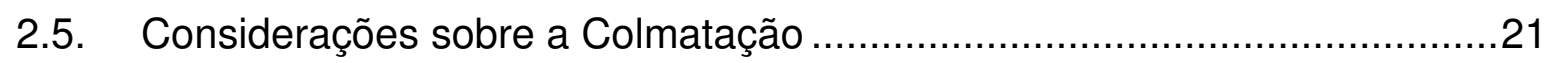

3. PAVIMENTOS PERMEÁVEIS - DESCRIÇÃO .............................................22

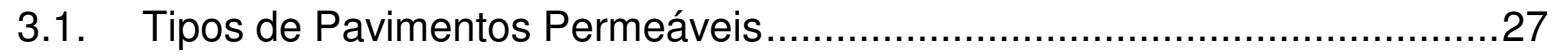

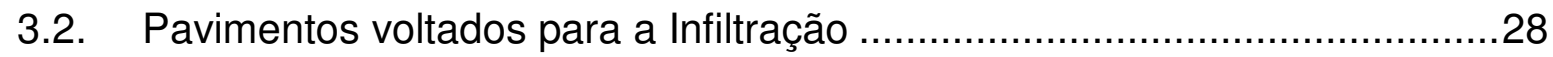

3.3. Pavimentos voltados para a Detenção e Armazenamento .........................29

3.4. Princípio de Funcionamento e Tipos de Pavimentos ...................................31

3.5. Componentes dos Pavimentos Permeáveis ............................................33

3.5.1. Revestimento, Base e Sub-base.....................................................

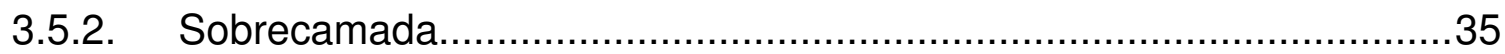

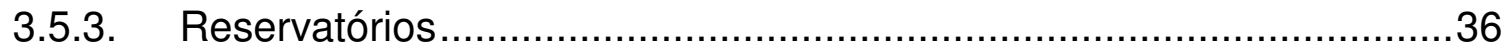

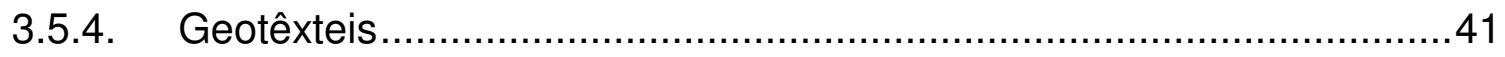

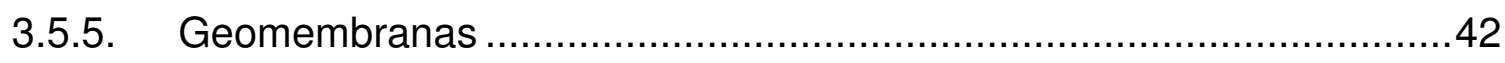

3.6. Materiais usados em Pavimentos Permeáveis ........................................43

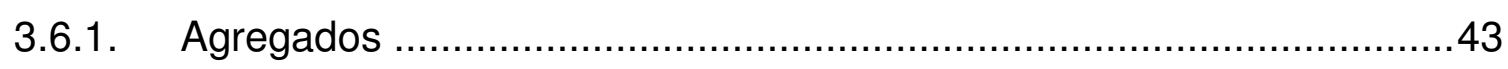

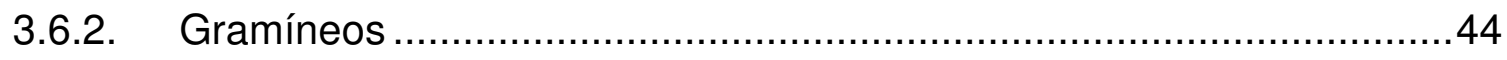

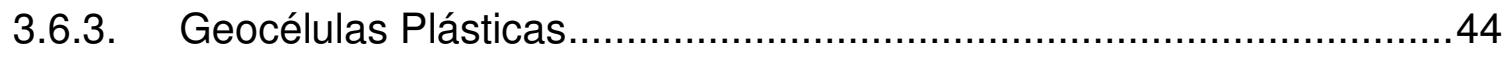

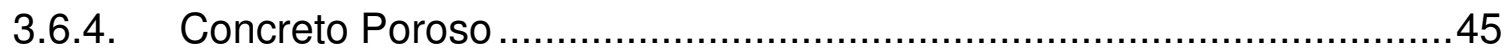

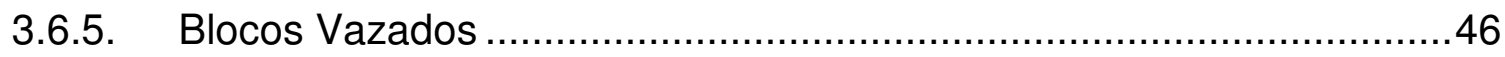




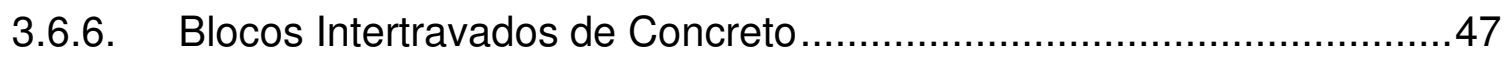

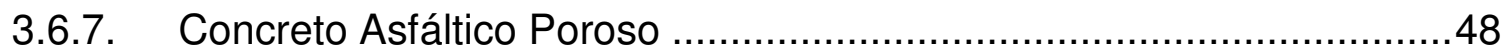

3.7. Estudo das Peças Pré-Moldadas de Concreto - PPC ................................49

3.7.1. Pavimentos Intertravados de Concreto ...............................................49

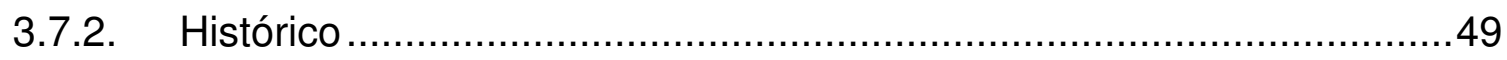

3.7.3. Características de uso dos Blocos de Concreto. ................................50

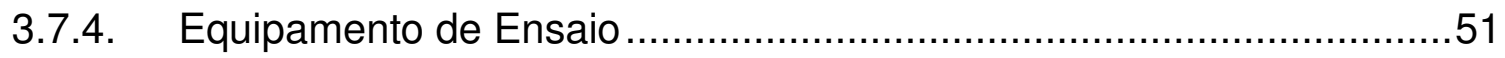

3.7.5. Determinação da Resistência à Compressão (fpj)............................52

3.7.6. Valor Característico da Resistência à Compressão (fpk)......................53

3.7.7. Influências na Resistência do Concreto ..............................................53

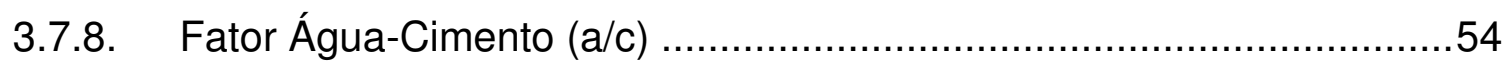

3.7.9. Influência da Idade do Concreto ...................................................54

3.7.10. Pavimento Permeável em Blocos de Concreto....................................55

3.7.11. Tipos de Blocos para Estruturas Permeáveis ....................................56

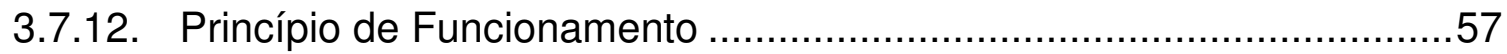

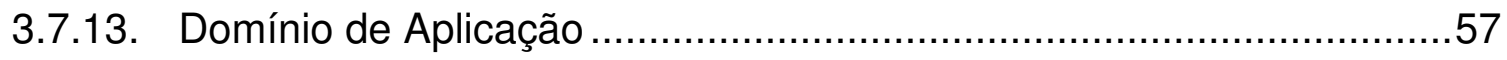

3.8. Estudo do Concreto Asfáltico Poroso .....................................................58

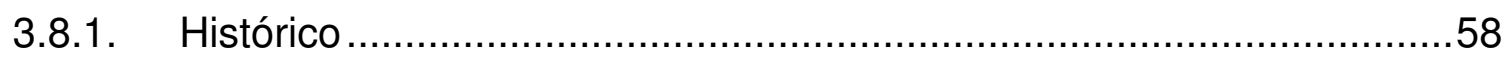

3.8.2. Características do Concreto Asfáltico Poroso.....................................59

3.8.3. Uso de Ligantes Modificados por Polímeros.....................................61

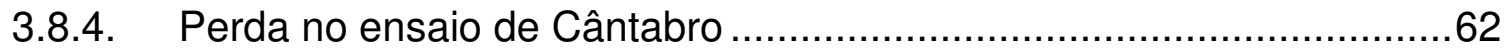

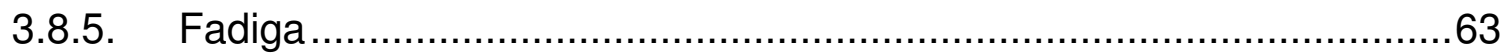

3.8.6. Envelhecimento e Oxidação …………............................................63

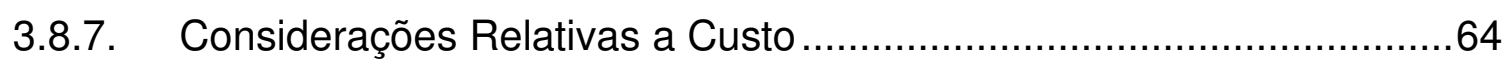

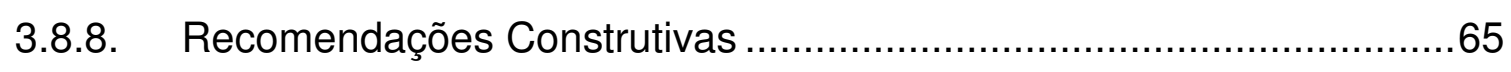

3.8.9. Formulação de Misturas para Revestimentos Porosos.........................66

3.8.10. Manutenção do Revestimento Poroso ………..................................67

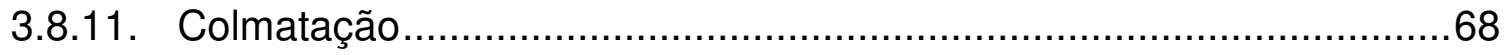

3.8.12. Degradações e Defeitos Localizados...............................................69

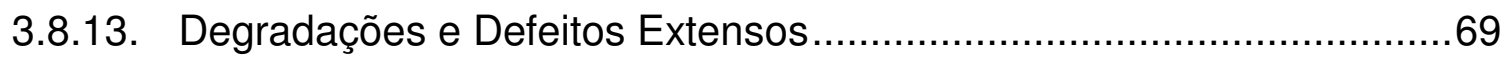

3.8.14. Recuperação no Fim da Vida Útil do Revestimento Poroso .................69

3.8.15. Segregação e Faixa Granulométrica ..............................................70

4. DIRETRIZES DE PROJETO E EXECUÇÃO DO PAVIMENTO PERMEÁVEL ..73

4.1. Fluxograma das Atividades de Projeto...................................................74 


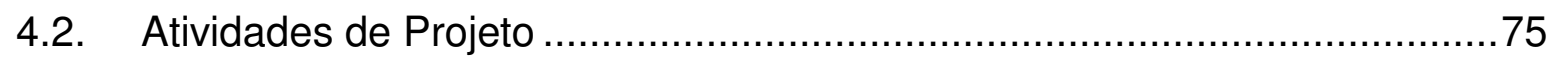

4.2.1. Concepção Funcional do Empreendimento …..................................75

4.2.2. Concepção do Pavimento Permeável.............................................75

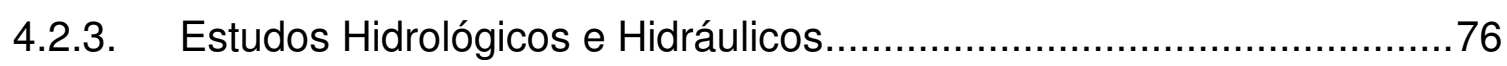

4.2.4. Serviços Geológicos - Geotécnicos ............................................. 81

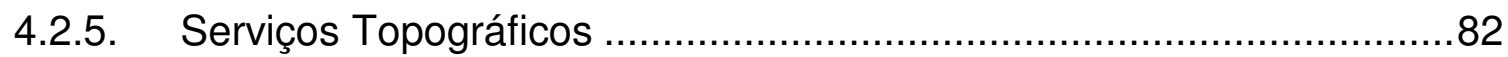

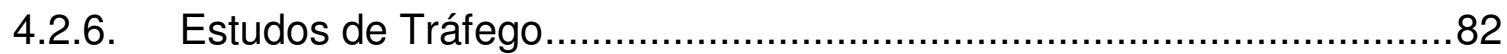

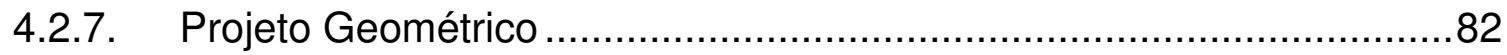

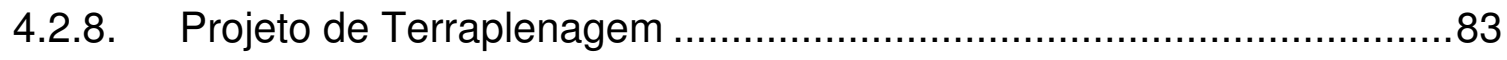

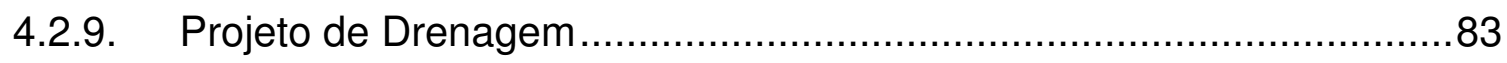

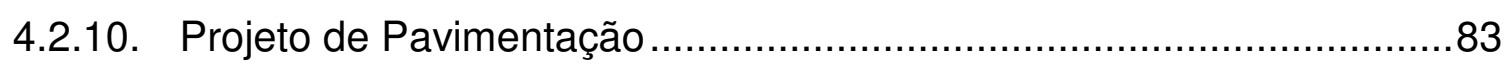

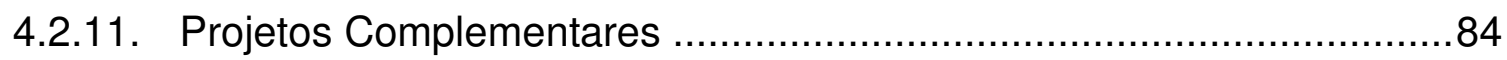

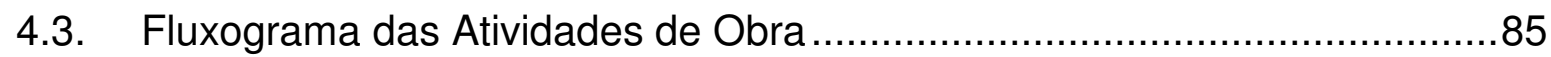

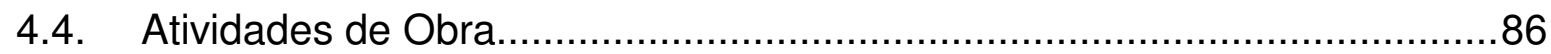

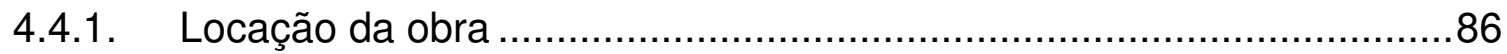

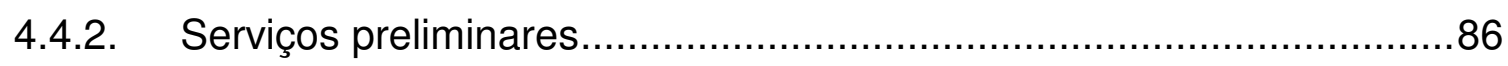

4.4.3. Abertura da caixa e preparo do subleito …...................................... 87

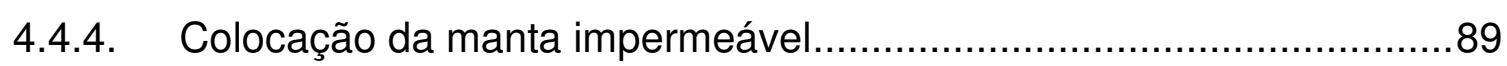

4.4.5. Execução das camadas de base e sub-base drenante ......................90

4.4.6. Execução dos dispositivos de drenagem .........................................91

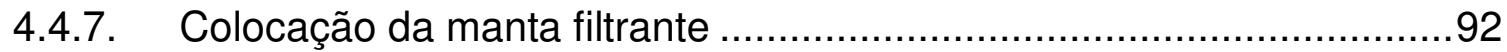

4.4.8. Execução do revestimento permeável. .............................................93

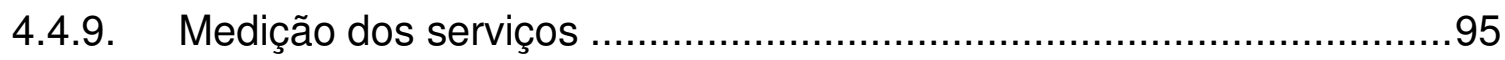

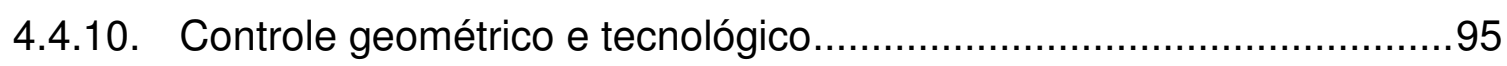

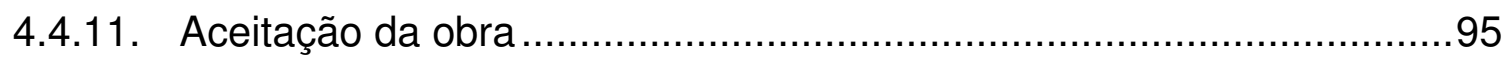

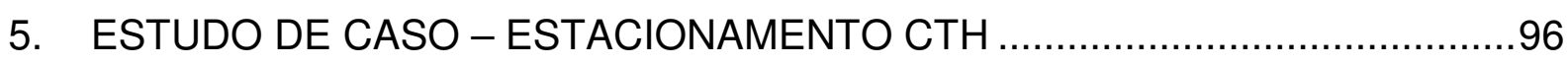

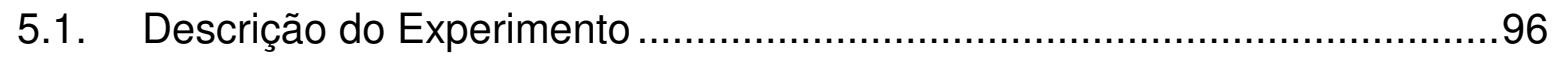

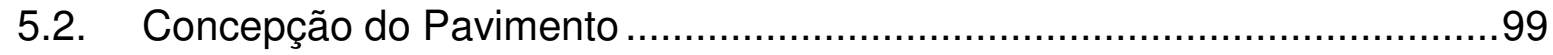

5.3. Estudos Hidrológicos e Hidráulicos..................................................102

5.4. Serviços Geotécnicos e Geológicos...................................................106

5.4.1. Ensaios Correntes ................................................................106

5.4.2. Classificação pelo Método MCT …………................................109

5.4.3. Conclusão dos Serviços Geotécnicos............................................112

5.5. Serviços Topográficos...................................................................113 


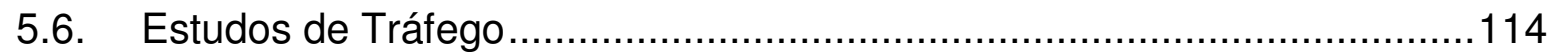

5.7. Projetos Geométrico, de Terraplenagem e de Drenagem.......................115

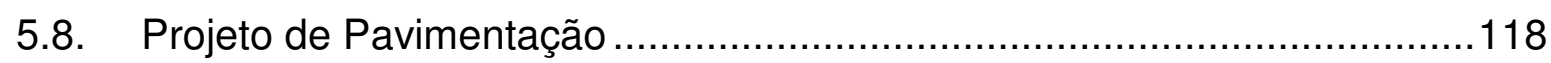

5.8.1. Dimensionamento dos Pavimentos Flexíveis (CPA) .........................118

5.8.2. Dimensionamento de Pavimentos com Blocos ................................121

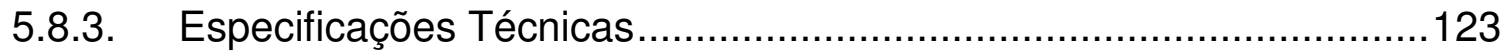

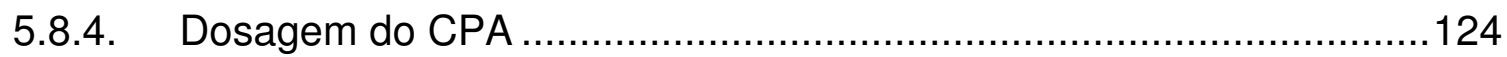

5.8.5. Perfil Final adotado para a Obra ..............................................127

5.9. Transplante de Espécies Arbóreas .....................................................129

5.10. Medição da Permeabilidade do Revestimento Poroso..............................132

5.11. Comparação de Preços dos Pavimentos ...............................................134

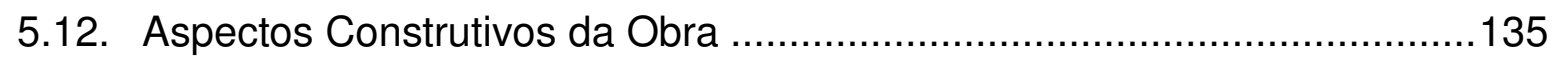

6. CONCLUSÕES E RECOMENDAÇÕES ….................................................150

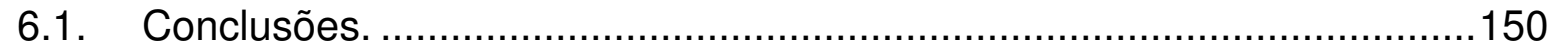

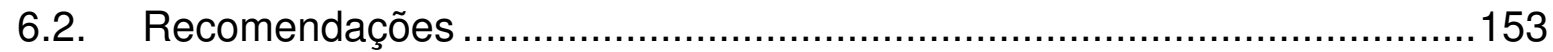

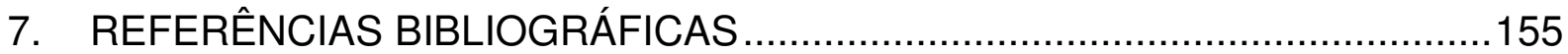

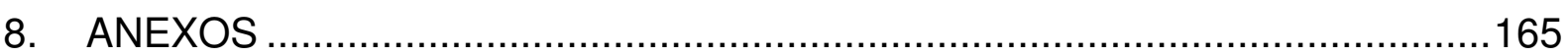

8.1. ANEXO A - Termo de Compromisso Ambiental ....................................165

8.2. ANEXO B - Boletins da Sondagem ...................................................172

8.3. ANEXO C - Perfis Geotécnicos e Classificação MCT ............................176

8.4. ANEXO D - Dosagem do CPA ........................................................187 


\section{INTRODUÇÃO}

As ações públicas para soluções de problemas de drenagem urbana são, na maioria das vezes, uma continuação do princípio de drenar as águas das precipitações o mais rápido possível para jusante.

O aumento cada vez maior das áreas urbanas impermeáveis, resultado da concentração populacional em grandes cidades, justaposto a conseqüente interferência humana no ciclo hidrológico, tem obrigado o poder público a adotar medidas que buscam a eliminação dos efeitos produzidos pelas chuvas intensas.

O resultado da ação antrópica nesse meio tem sido o aumento das enchentes, inundações e a degradação acentuada da qualidade das águas com o acréscimo da produção de lixo e conseqüente aumento dos vetores patogênicos de transmissão de doenças e poluição.

Redes de drenagem, que apenas transferem a inundação de um ponto para outro a jusante da bacia, resolvem parte do problema.

Novos conceitos tendem resgatar as condições de pré-urbanização utilizando dispositivos que possibilitem acréscimo de infiltração e aumento do tempo de retardo de escoamento superficial próximo ao ponto de origem ou fonte.

Neste sentido, um dispositivo utilizado para essa finalidade é o pavimento permeável que possui a capacidade de reduzir os volumes de escoamento superficial e reduzir os picos de cheia. É um dispositivo de infiltração que absorve inteiramente ou parte do escoamento através de uma superfície permeável para dentro de um reservatório de brita de graduação uniforme construída sobre o perfil do terreno.

A água captada pelo pavimento pode ser conduzida para um reservatório, e deste para um ponto de saída ou captação, ou simplesmente ser absorvida pelo solo. A sub base e base dos pavimentos permeáveis, construídas por agregados de granulometria aberta e com poucas partículas finas, atuam como um recipiente de 
coleta d'água deixando que o líquido permaneça nos vazios das camadas. O correto dimensionamento da espessura das camadas, levando-se em consideração as premissas de volume de tráfego, tipo de carregamento, número de solicitações e outros fatores mecânicos, associados às premissas hidráulicas de tempo de armazenamento, tempo de retenção e condutividade hidráulica, permitem a execução de um pavimento permeável que atenda simultaneamente aos anseios da Engenharia de Transportes, da Engenharia Hidráulica e da sustentabilidade.

\subsection{Estrutura do Trabalho}

Além desta introdução o trabalho é constituído por mais 7 capítulos conforme descrição mostrada a seguir:

O capítulo 1 refere-se à introdução comentando sucintamente como o aumento das áreas urbanas impermeáveis têm movido órgãos ligados a engenharia à busca de soluções visando resgatar condições anteriores de pré-urbanização através de novos conceitos, materiais e técnicas que contribuam para a mitigação de eventos severos de cheias e seus problemas associados.

O capítulo 2 aborda a evolução e os problemas da drenagem sob a ótica da Engenharia Hidráulica analisando os sistemas adotados no passado e outros mais modernos quanto a sua utilização.

São mostradas medidas não estruturais e compensatórias de drenagem que visam minimizar os efeitos das cheias que normalmente ocorrem em centros densamente urbanizados.

Dá-se destaque a enfoques diferentes adotados para o controle do escoamento superficial direto de águas pluviais, ou seja, o controle ou gerenciamento das águas visando sua maior condutividade hidráulica bem como aquele orientado para o armazenamento visando o abatimento dos picos de cheias. 
Trata de dispositivos cujo objetivo é o de contornar os problemas gerados pela urbanização exacerbada de bacias sob o efeito das inundações. Tais dispositivos serão descritos rapidamente através de conceitos estruturais e não estruturais de forma a fornecer noções de alternativas para a redução de inundações, diminuição dos efeitos erosivos, melhorias das condições de reuso e recarga de aqüíferos além da redução das vazões a jusante melhorando o tempo de concentração do escoamento na bacia hidrográfica.

Além disso, são abordados os problemas decorrentes da dificuldade de infiltração e a maneira como ocorre o avanço da frente de molhamento no subsolo e, por fim são tecidas algumas considerações sobre o fenômeno da colmatação numa estrutura drenante.

O capítulo 3 trata dos pavimentos permeáveis propriamente ditos desde sua história recente até as mais novas técnicas desenvolvidas neste segmento.

Destaca-se as funções realizadas e os tipos mais freqüentes de revestimentos drenantes voltados à infiltração ou detenção e armazenamento.

Descreve-se sucintamente seu funcionamento e aplicações, bem como de seus componentes e materiais de que se constituem. Apresentam-se os tipos de reservatórios mais comuns utilizados como dispositivos de descarga.

São destacados os materiais que podem ser tratados como elementos porosos e de alta permeabilidade e que conferem aos pavimentos a propriedade de suporte a carregamentos dinâmicos ou estáticos.

Aborda aspectos relacionados às PPC (peças pré-moldadas de concreto) e ao concreto asfáltico poroso tipo CPA quanto a suas características e propriedades

No capítulo 4 são apresentadas diretrizes sobre o projeto e a execução do pavimento permeável, levando-se em consideração as etapas necessárias à sua implementação. 
É mostrada a seqüência dos trabalhos tendo-se por base a experiência adquirida e utilizada para o planejamento, o projeto e a execução da obra propriamente dita.

Apresenta as atividades relacionadas à elaboração do projeto e as relacionadas à execução das etapas construtivas, indicando os estudos, ensaios, dimensionamento e especificações técnicas utilizados.

O capítulo 5 aborda o estudo de caso da construção do trecho experimental (estacionamento) localizado nas dependências do CTH - Centro Tecnológico de Hidráulica da Universidade de São Paulo USP, onde estão sendo executados os dois tipos de revestimentos permeáveis.

Apresenta a descrição das etapas críticas do experimento e as soluções adotadas.

No capítulo 6 são apresentadas principais conclusões e recomendações do trabalho desenvolvido.

No capítulo 7 são mostradas as principais referências bibliográficas nacionais e estrangeiras consultadas e utilizadas para o desenvolvimento do estudo.

O capítulo 8 foi destinado a apresentação de Anexos que subsidiaram alguns pontos importantes do trabalho como resultados de ensaios, pesquisa e documentação. 


\subsection{Objetivos da Dissertação}

Tendo em vista a falta de instruções de projeto e procedimentos de construção específicos para a execução dos pavimentos permeáveis, o presente trabalho procura apresentar uma contribuição para a consecução desses objetivos propondo diretrizes técnicas que possam ser utilizadas sistematicamente para a implementação desses dispositivos para o controle do escoamento superficial de águas pluviais na fonte.

Pretende-se fornecer elementos de projeto e instruções para execução da obra de pavimentos permeáveis como solução viável e complementar de drenagem em diferentes empreendimentos urbanos como grandes áreas públicas ou particulares, estacionamentos, parques, quadras esportivas, passeios, calçamentos e ruas de pouca solicitação de tráfego.

Espera-se que o material apresentado possa servir de base para a consecução de metodologia mais eficaz de projeto e construção de pavimentos permeáveis visando sua utilização pelo poder público e privado como mecanismo de controle de escoamento na fonte e medida compensatória não estrutural de drenagem urbana além de seu uso como sistema mitigador dos efeitos de inundações em grandes centros urbanos.

A experiência adquirida na construção da área de estacionamento como trecho experimental, servirá também ao desenvolvimento de outros estudos que necessitam mais tempo de coleta de dados como, por exemplo, a análise do efeito da colmatação sobre as estruturas drenantes, e o estudo da qualidade das águas sob o efeito da poluição difusa. 


\section{DRENAGEM URBANA - EVOLUÇÃO E PROBLEMAS DECORRENTES}

Constata-se, desde tempos mais remotos, a grande ligação de aglomerados urbanos com cursos d'água. Vilas, vilarejos e pequenos centros, na maioria das vezes, se instalavam próximos a rios, riachos, córregos e corpos d'água pela facilidade de obtenção de suprimento para consumo e higiene de suas populações. A disponibilidade de água em abundância constituía um importante insumo também para a agricultura, comércio, comunicação e navegação.

Algumas cidades da antigüidade como Babilônia, se posicionavam ao lado de grandes rios no caso o Eufrates, que também servia de proteção militar contra povos invasores.

A proximidade aos cursos d'água acarretava freqüentemente problemas de enchentes e inundações que afligiam as populações ribeirinhas. Entretanto, o risco dessas ocorrências era bem aceito por ser considerado um "preço a pagar" pela disponibilidade da água.

A partir do surgimento de preceitos higienistas que preconizavam a canalização e o controle dos cursos d'água urbanos, como meio de reduzir a ocorrência de doenças de veiculação hídrica, a relação harmônica entre aglomerados urbanos e cursos d'água foi alterada. A mudança radical advinda do conceito higienista, ou seja, da eliminação rápida das águas pluviais e servidas para longe das cidades reduziu drasticamente o papel dos cursos d'água no quadro urbanístico como elemento da paisagem e fator de embelezamento. Antes, águas servidas eram despejadas nas vias públicas ficando confinadas aos centros urbanos, trazendo questões sanitárias e de insalubridade como o risco de epidemias e doenças. (Baptista \& Nascimento, 2005).

Outro ponto a considerar é o vertiginoso crescimento populacional demonstrado pelos relatórios de evolução demográfica mundial desde 1950 e projeções para o ano de 2030 elaborados pela Organização das Nações Unidas ONU, 2006, em que 
se demonstra a aceleração do crescimento nas áreas urbanas e decréscimo de população nas áreas rurais conforme Tabela 1 e Gráfico 1.

\begin{tabular}{|l|l|l|l|l|l|}
\hline \multicolumn{7}{|c|}{ População mundial para o período de 1950-2030 (bilhões) } \\
\hline & $\mathbf{1 9 5 0}$ & $\mathbf{1 9 7 5}$ & $\mathbf{2 0 0 0}$ & $\mathbf{2 0 0 5}$ & $\mathbf{2 0 3 0}$ \\
\hline URBANA & 0,73 & 1,52 & 2,84 & 3,15 & 4,91 \\
\hline RURAL & 1,79 & 2,56 & 3,24 & 3,31 & 3,29 \\
\hline TOTAL & 2,52 & 4,08 & 6,08 & 6,46 & 8,2 \\
\hline \multicolumn{7}{|c|}{ Porcentagem de habitantes em áreas urbanizadas } \\
\hline
\end{tabular}

Tabela 1 - População mundial e projeção para 2030 (fonte: World Urbanization Prospects - The 2005 Revision ONU, 2006)

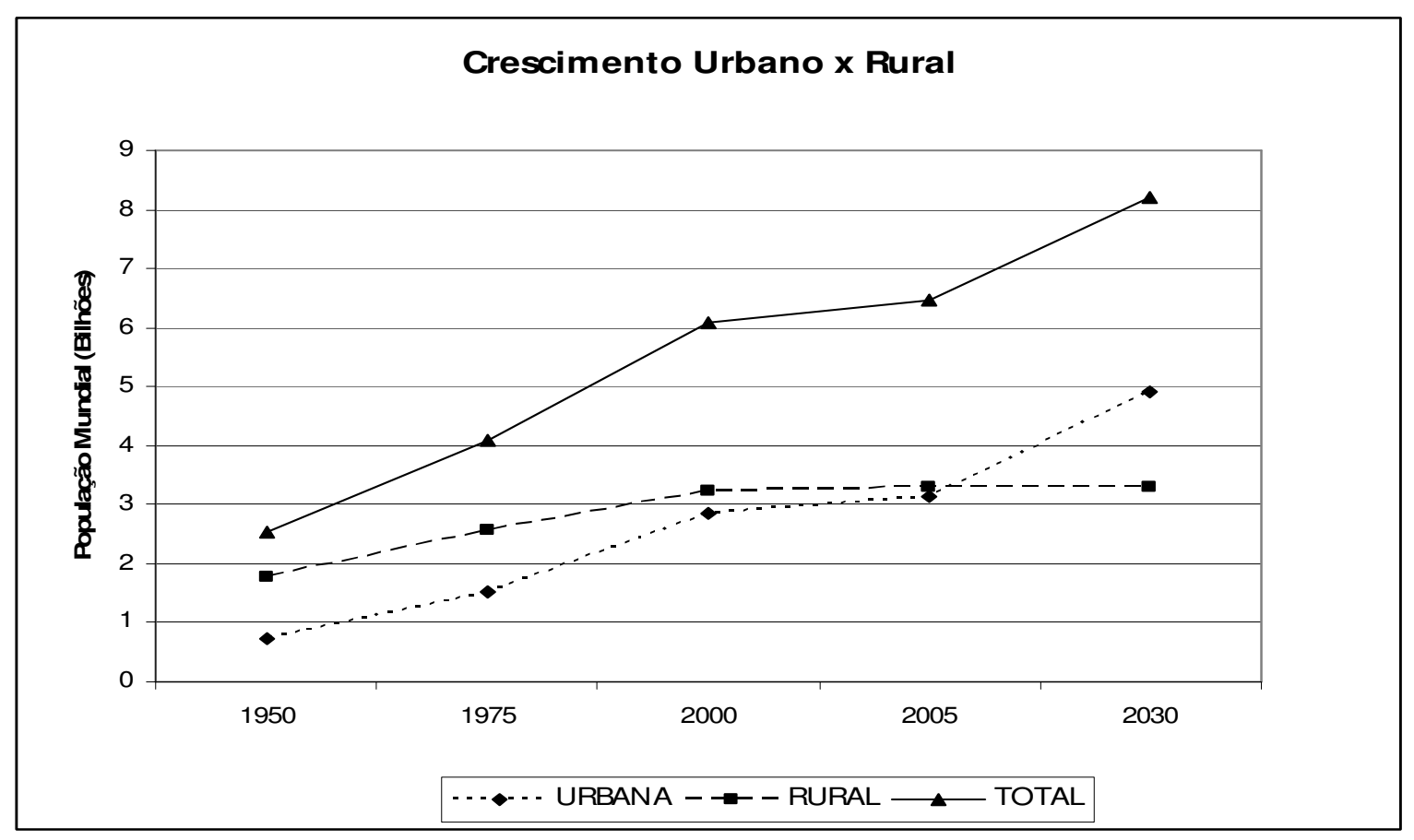

Gráfico 1 - Evolução demográfica em áreas urbanas e rurais (Fonte: World Urbanization Prospects - The 2005 Revision ONU, 2006). 
No Brasil, estudos recentes do IBGE demonstram o fenômeno do rápido crescimento nas áreas urbanas que chega a $84 \%$ em relação ao decréscimo da população rural da ordem de $16 \%$.

O crescimento dos limites territoriais urbanos (Gráfico 2), trás consigo, novamente a questão das enchentes, pois a ação antrópica sobre o solo, alterando suas características de absorção e a recarga natural de aqüíferos, enfatiza inexoravelmente a utilização de sistemas de escoamento das águas superficiais de forma rápida para sistemas maiores de captação até seu destino final nos cursos d'água, que mostram-se com o tempo, insuficientes para comportar volumes cada vez maiores de contribuição.

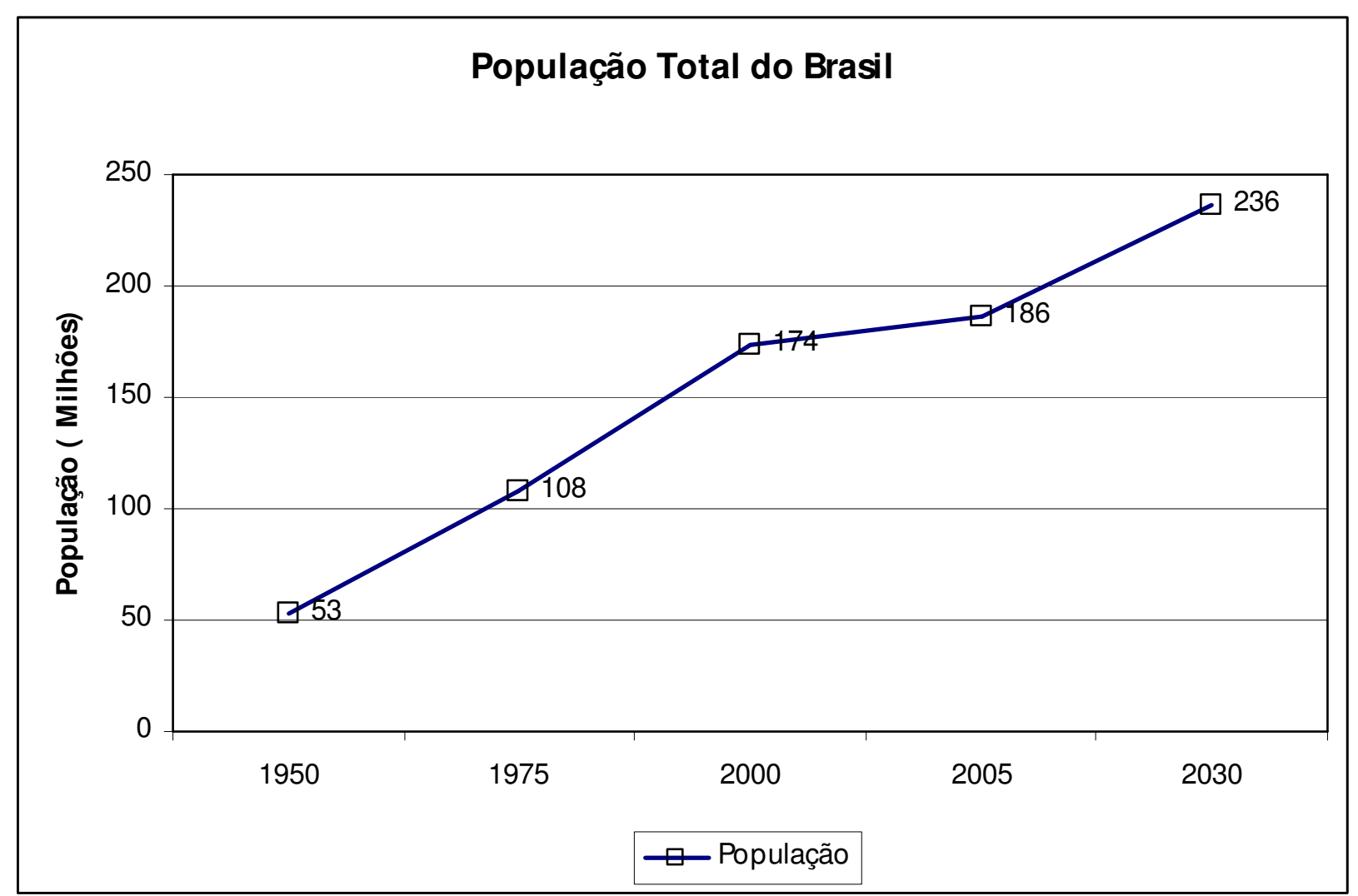

Gráfico 2 - Evolução demográfica no Brasil. (Fonte: World ONU Urbanization Prospects - The 2006 Revision Population Database, 2007).

De acordo com Baptista \& Nascimento (2005), a transferência da carga hidráulica para jusante gera o mesmo tipo de problema de maneira mais intensa e rápida nas concentrações urbanas localizadas ao longo dos cursos d'água. 
Ainda sob a ótica higienista, a urbanização acelerada, implica em intervenções nos processos hidrológicos em particular a ação direta nos cursos d'água e na superfície das bacias hidrográficas. Em vista disso, a redução das áreas permeáveis e do armazenamento superficial, associado ao aumento da velocidade de escoamento, contribui para eventos mais severos de inundações e enchentes, simplesmente pelo aumento dos picos de cheia.

\subsection{Sistemas de Drenagem Urbana}

Baptista \& Nascimento (2005) trataram a questão da drenagem urbana através de duas abordagens em relação aos sistemas de intervenção hidráulica: o tradicional ou clássico com base higienista e o técnico alternativo com base em medidas compensatórias de drenagem e controle na origem.

\subsubsection{Sistema Clássico}

Os preceitos higienistas para drenagem de águas pluviais e servidas recomendam sua rápida evacuação das áreas urbanas, por meio da utilização de condutos preferencialmente subterrâneos funcionando por gravidade. São constituídos basicamente de dispositivos de micro-drenagem que efetuam o transporte das águas superficiais nas ruas (sarjetas), sua captação (bocas de lobo) e o deságüe até sistemas de macro-drenagem constituídos de canais abertos ou galerias. 


\subsubsection{Sistema Alternativo ou Compensatório}

A partir de 1970, outra abordagem para tratar o problema das enchentes foi desenvolvida na Europa e América do Norte. Trata-se do conceito de "tecnologias alternativas" ou "compensatórias" de drenagem, que buscam neutralizar os efeitos da urbanização sobre os processos hidrológicos, com benefícios para a qualidade de vida e preservação ambiental.

Essas tecnologias são alternativas, em relação às clássicas, pois consideram o impacto da urbanização de forma geral, buscando compensar sistematicamente os seus efeitos. A compensação é efetuada pelo controle do excesso de água oriunda da impermeabilização, evitando-se sua transferência rápida para jusante.

Neste contexto, medidas não estruturais são recomendadas e podem contribuir para minimizar as cheias e inundações, conforme Baptista \& Nascimento (2006) tais medidas são :

- Bacias ou reservatórios de detenção ou bacias de amortecimento de cheias;

- Estruturas de armazenamento temporário, implantadas por simples adequação de configuração topográfica em áreas de estacionamento, terrenos esportivos e áreas livres em geral;

- Pavimentos porosos ou permeáveis, destinados ao armazenamento temporário e/ou infiltração, em áreas de estacionamento e no sistema viário;

- Estruturas que favorecem a infiltração e a percolação, tais como trincheira, poços, valas, valetas etc.;

- Canalizações em cursos d'água com técnicas que favorecem o escoamento lento ou mesmo a detenção temporária das águas; 
- Tratamento do fundo dos vales com zoneamento de planícies de inundação e delimitação de áreas non aedificandi destinadas ao armazenamento temporário (Baptista \& Nascimento, 2005).

\subsection{Enfoques da Drenagem Urbana}

Existem fundamentalmente dois enfoques ou diferentes soluções para o controle da quantidade das águas do escoamento superficial direto em áreas urbanas; o orientado para 0 aumento da condutividade hidráulica e o orientado para 0 armazenamento das águas. (Scarati Martins , 2006).

\subsubsection{Condutividade Hidráulica Controlada}

Conforme abordado, é o mais tradicional ou clássico e enfatiza o aumento da condução hidráulica do sistema de drenagem urbana. Os sistemas projetados de acordo com este enfoque efetuam a coleta das águas do escoamento superficial direto, conduzindo-as de imediato e rapidamente até o ponto de despejo.

Os sistemas projetados dentro desta filosofia tendem a aumentar as vazões veiculadas, podendo resultar em áreas de inundações a jusante, em relação à condição anterior à sua implantação (Scarati Martins , 2006).

São sistemas que exigem manutenção periódica como remoção de sujeira e detritos, obras de desassoreamento e recuperação estrutural entre outras.

\subsubsection{Armazenamento das Águas}

A utilização deste enfoque mais moderno tem-se mostrado, ao longo dos anos, como solução eficiente para áreas já urbanizadas. Sua função é realizar o armazenamento temporário das águas de escoamento superficial direto próximo ao ponto de origem e efetuar a liberação das águas de maneira lenta e gradativa ou 
simplesmente deixando a água se infiltrar no solo. Trata-se de controle realizado na fonte ou perto dela.

Representa uma medida compensatória efetiva à perda da capacidade natural de infiltração dos solos de uma bacia hidrográfica que se tornou densamente urbanizada. Ao mesmo tempo em que propicia o armazenamento das águas, pode também proporcionar o aumento da duração dos hidrogramas, com a conseqüente redução dos picos das cheias reduzindo os impactos para jusante.

O desenvolvimento sustentável pressupõe necessariamente que haja equilíbrio ecológico, benefício social e viabilidade econômica. Nesta perspectiva, a implantação do pavimento permeável pode estimular a conscientização da população e servir de incentivo à adoção de ações para garantir a sustentabilidade às áreas urbanas incorporando conceitos de qualidade ambiental e tecnológica, uso racional de materiais e recursos e aplicação de métodos eficazes que visam contribuir para o manejo e controle do escoamento superficial repondo condições anteriormente perdidas pelo uso desordenado do solo urbano que trouxe como conseqüência a impermeabilização.

Revisões, atualizações das normas e especificações técnicas de matérias e procedimentos devem ser pensados objetivando soluções ambientalmente responsáveis e dentro de conceitos pertinentes à sustentabilidade de todos os processos. 


\subsection{Efeitos da Urbanização}

De acordo com Scarati Martins (2006) os fatores do ciclo hidrológico, diretamente afetados pela urbanização são:

- O volume do escoamento superficial direto;

- Os parâmetros de tempo do escoamento superficial;

- A vazão de pico das cheias.

Esses efeitos são causados por alterações da cobertura do solo, modificações nos sistemas de drenagem, usualmente a retificação e canalização de cursos d'água e a ocupação urbana das várzeas com aterros e sistemas viários e a posterior impermeabilização de parte da área ocupada.

Constata-se que aos picos de cheia depois da urbanização passam a ocorrer mais cedo e com mais severidade do que antes do desenvolvimento onde as características de uso e ocupação favoreciam a infiltração (Figura 1).

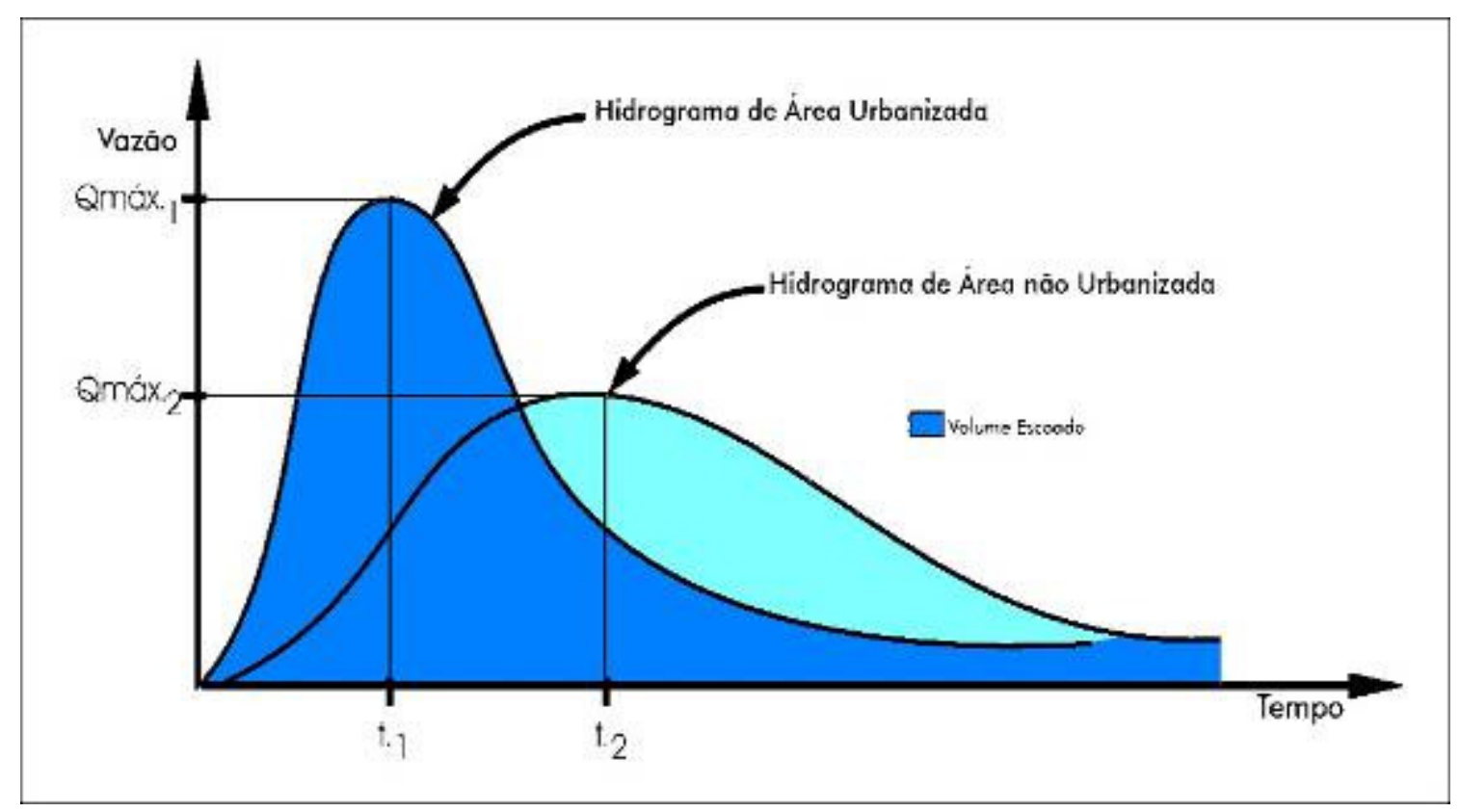

Figura 1 - Efeitos da urbanização sobre o hidrograma da bacia. (adaptado de Cordeiro Netto,1994). 
São conhecidos os exemplos que relacionam o crescimento das vazões máximas de cheias com a área urbanizada da bacia e a área servida por obras de drenagem que, em alguns casos, podem resultar em picos de cheia da ordem de 6 vezes o valor do pico da mesma cheia em condições naturais. Tucci e Genz, (1995), demonstraram que os dispositivos para controle de drenagem na fonte diminuem e retardam os picos de cheia chegando a cenários iguais ou melhores que o da préurbanização.

Cabe frisar que o volume do escoamento superficial direto é primordialmente determinado pela quantidade de água precipitada, características de infiltração do solo, chuva antecedente, tipo de cobertura vegetal, superfície impermeável e retenção superficial conforme Scarati Martins (2006).

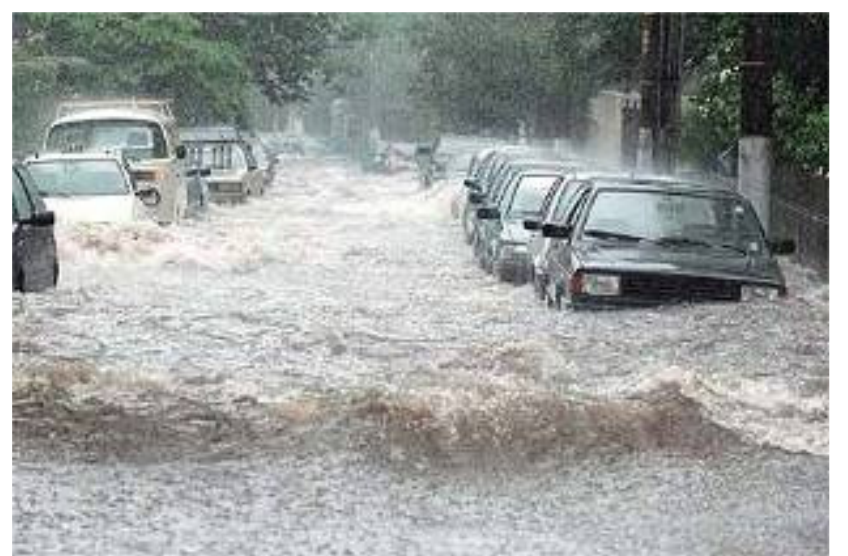

Foto 1 - Escoamento superficial em evento severo de precipitação - Fonte: Jornal O Estado de São Paulo 23/09/2003.

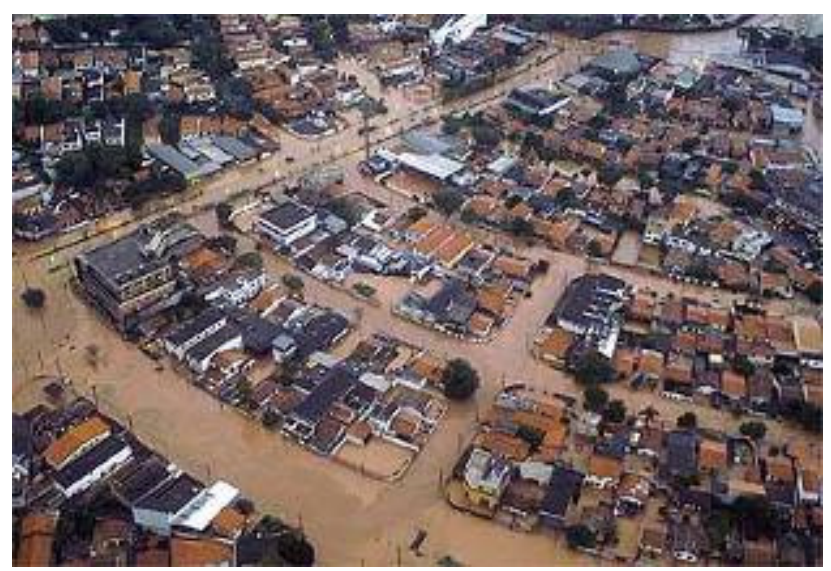

Foto 2 - Alagamento no bairro do Morumbi em São Paulo - Fonte: Jornal O Estado de São Paulo 23/09/2003 
Os efeitos da urbanização estão diretamente associados ao aumento do volume do escoamento superficial, combinado com o decréscimo no volume de escoamento de base e decréscimo no tempo de concentração (Walesh ,1989).

Araújo et. al. (1999) apontam que a falta de planejamento na ocupação das áreas urbanas resulta em alterações significativas nas taxas de impermeabilização das bacias, ocasionando transtornos e prejuízos em razão do aumento significativo das inundações.

O volume que escoava lentamente no solo e ficava retido pela vegetação e em depressões, passa a escoar em canais, exigindo maior capacidade de escoamento das seções que com o tempo deixam de comportar os volumes anteriormente projetados.

A falta de planejamento e regulamentação é sentida em praticamente todas as cidades de médio e grande porte do país. Depois que o espaço está totalmente ocupado, as soluções disponíveis são extremamente caras, tais como canalizações, diques com bombeamentos, reversões, reservatórios de retenção ou "piscinões" entre outras. O poder público passa a investir parte significativa de seu orçamento para proteger uma parcela da cidade que sofre devido à imprevidência da ocupação do solo (Villanueva, 1997).

Neste sentido, verifica-se que a canalização de córregos, sem a devida análise de impactos a jusante, pode agravar a situação em outros pontos (Tucci, 2000).

$\mathrm{Na}$ Figura 2, observam-se as diferenças no hidrograma de montante e jusante devido a modificações na área urbana provocadas por sistemas de drenagem. 


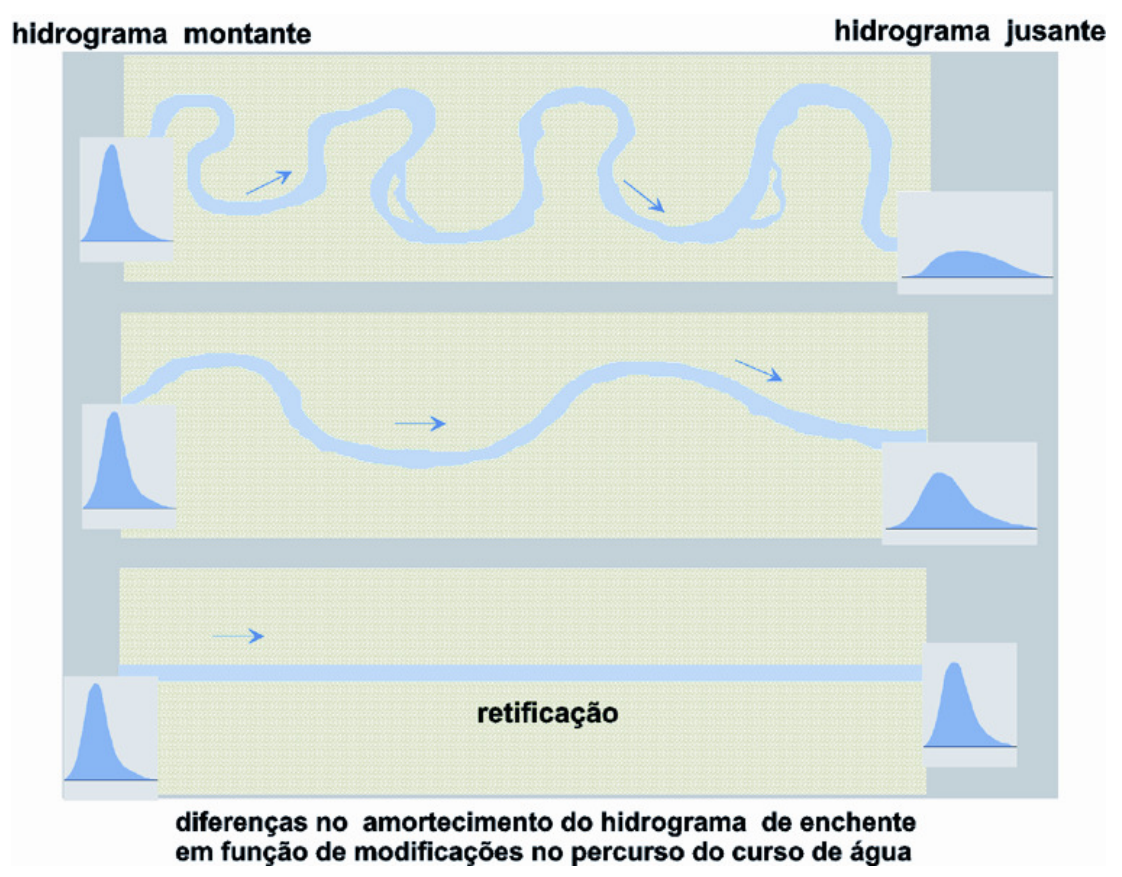

Figura 2 - Diferenças nos hidrogramas urbanos de montante e jusante com sistema estrutural de drenagem, SEMADS, 2001

\subsection{1. Área Impermeabilizada}

De acordo com Silveira (1998), o Brasil enfrentou um crescimento vertiginoso das metrópoles nacionais e regionais, isso fez com que a capacidade de investimento em obras de saneamento (incluindo a drenagem urbana) fosse inferior à expansão das cidades. Devido a este problema, as redes de drenagem, em alguns casos, são concebidas sem uma visão global de bacia hidrográgica.

Mota e Tucci (1984) e posteriormente Campana e Tucci (1992), iniciaram o trabalho de estimativa da taxa de impermeabilização em função da densidade habitacional por hectare urbano através da interpretação com tratamento matemático de fotos aéreas das cidades de Curitiba, São Paulo, Brasília e Porto Alegre chegando ao prognóstico de tendência a impermeabilização próximo a $65 \%$.

Atualmente o parâmetro mais representativo para estimativa da impermeabilização urbana é o numero de domicílios e tipos de uso do solo urbano. 


\subsubsection{Dispositivos de Detenção e Amortecimento}

Visando contornar o problema criado com a urbanização das bacias sobre 0 comportamento das cheias, que causam inundações nas áreas ribeirinhas, diversas medidas estruturais e não estruturais podem ser adotadas. Dentre as estruturais pode-se citar a do uso de bacias de detenção, ou seja, reservatórios de armazenamento de curtos períodos que reduzem as vazões de pico dos hidrogramas de cheias aumentando o seu tempo de retenção.

Normalmente os reservatórios de detenção não reduzem o volume de escoamento superficial direto, apenas redistribuem as vazões ao longo de um tempo maior armazenando temporariamente parte desse escoamento. Em menos de 24 horas os reservatórios de detenção são totalmente drenados.

Geralmente ocupam uma área que é seca e pode ser utilizada para fins de lazer ou recreação quando limpas e com sistema de alerta.

O armazenamento em reservatórios pode ser benéfico em reduzir problemas de inundação, reduzir os custos de sistemas de drenagem, melhorar a qualidade da água, diminuir efeitos de erosão, melhorar as condições de reuso e recarga de aqǘferos além de reduzir as vazões à jusante melhorando o tempo de resposta do escoamento superficial.

Por outro lado, o armazenamento nestes dispositivos requer manutenção constante, limpeza, medidas contra poluição e contaminação, cuidados com a proliferação de roedores e insetos, além disso, requer monitoramento de nível d'água e acionamento dos sistemas de esgotamento.

Os reservatórios são projetados para controlar os efeitos de chuvas localizadas de curta duração e alta intensidade, visto que esse tipo de precipitação é a causadora das inundações em pequenos cursos d'água. 
Sob o aspecto construtivo, podem ser criados pelo barramento de um rio, córrego ou curso escavando-se uma bacia no solo para represamento. Deve dispor de vertedor, cujo propósito é o de garantir a segurança da barragem e, em alguns casos, bacia de dissipação de energia à jusante da descarga para evitar a erosão localizada além de vertedor de emergência. Em qualquer caso é necessária a instalação de grade de retenção de lixo para impedir a obstrução das saídas. A Figura 3 apresenta um esquema representativo de um reservatório de detenção.
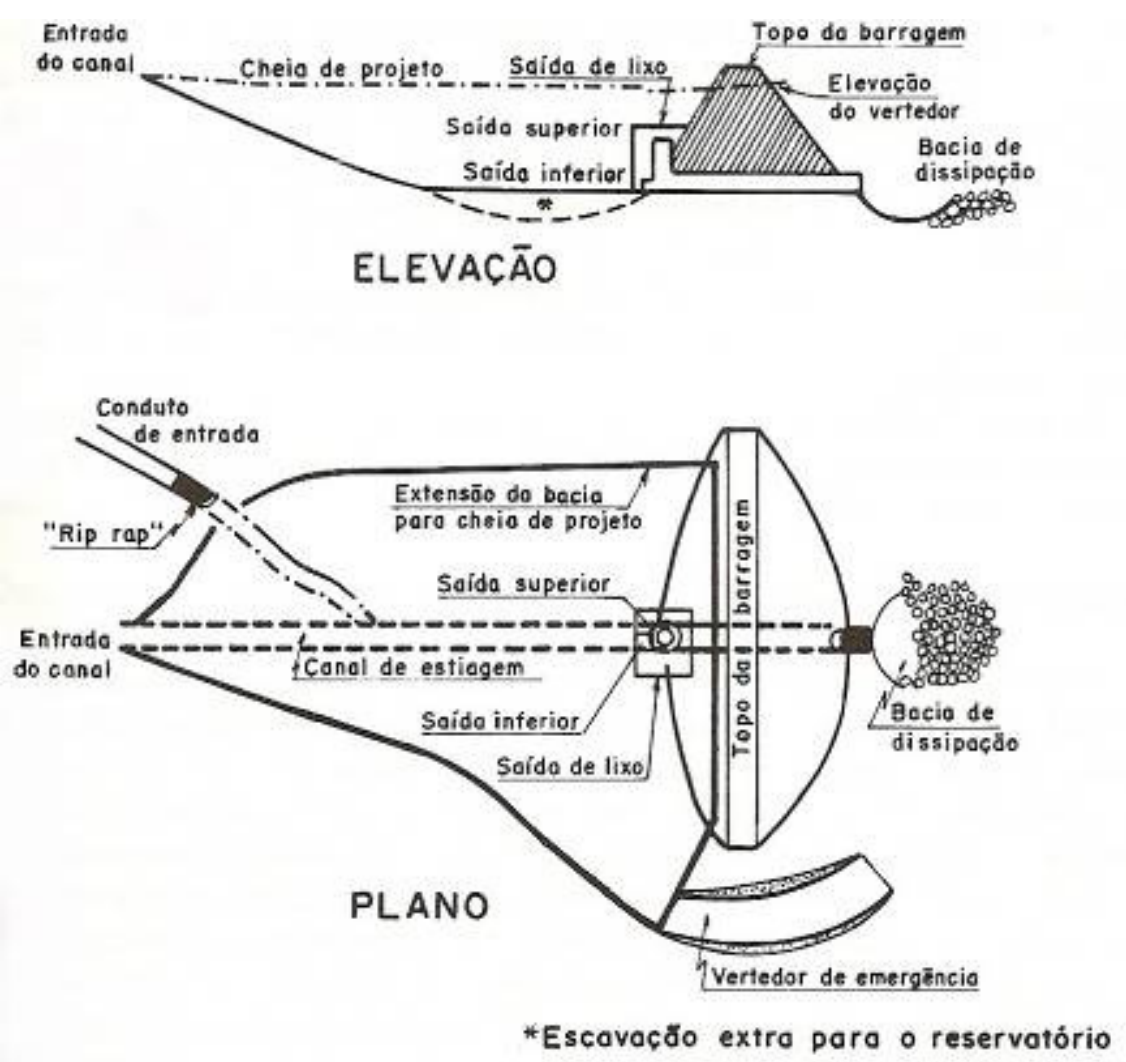

Figura 3 - Esquema de reservatório de detenção (Tucci - ABRH, 2000).

Os pavimentos permeáveis podem ser concebidos para atuarem como reservatórios de detenção armazenando o volume remanescente do escoamento superficial e, após a tormenta, drenar através de um exutório.

Outra aplicação dos pavimentos drenantes é sua atuação como reservatório de infiltração cujo volume não é devolvido a rede hidráulica, mas sim absorvido através do solo até o lençol freático, reabastecendo-o. 


\subsection{Dispositivos de Infiltração}

Denomina-se por infiltração o processo de penetração da água no solo, seguido de modificação quase instantânea das condições de pressão e teor de umidade, à superfície do solo, quando este entra em contato com a água. A infiltração se relaciona às características hidrodinâmicas, a estrutura e textura do solo bem como pelas condições iniciais e pela vazão de alimentação. (Baptista \& Nascimento (2005).

Pode ser considerada como uma perturbação do perfil hídrico que se propaga com a profundidade. O perfil hídrico se caracteriza por uma zona de saturação, uma zona de transmissão e uma zona de molhamento, cujo limite inferior é a frente de molhamento. (Figura 4).

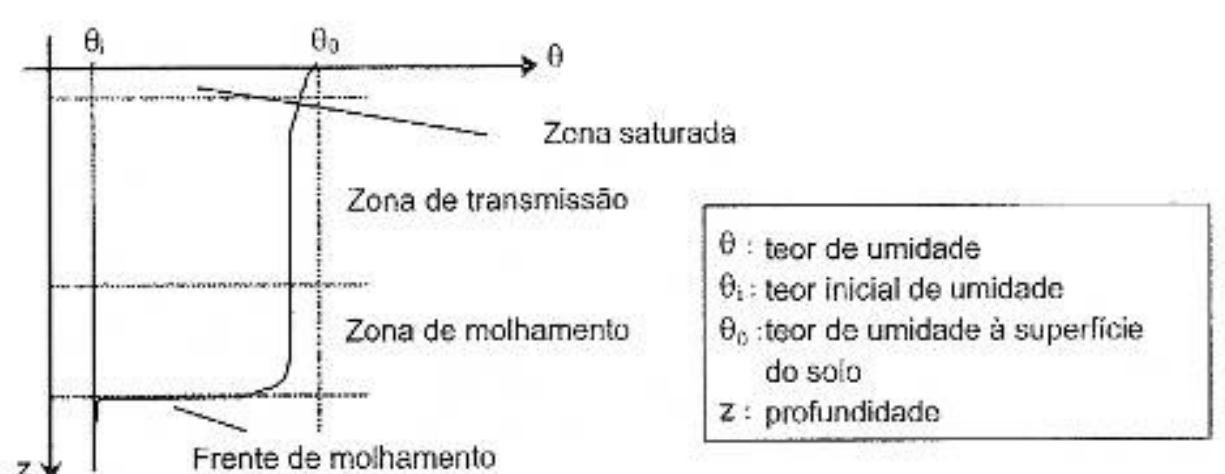

Figura 4 - Perfil hidráulico do solo durante a infiltração ( fonte: Musy et al.,1991)

De acordo com Baptista \& Nascimento (2005), a infiltração pode ser descrita em três fases conforme Figura 5.

$1^{\text {a }}$ Fase - Avanço da frente de molhamento. Quando se inicia o processo de alimentação de água de escoamento superficial até quando o lençol sob a estrutura recebe a água infiltrante. Trata-se de escoamento em meio não saturado, dependendo apenas da carga hidráulica na estrutura e na camada de solo inferior não havendo influência do lençol freático. 
2 ${ }^{a}$ Fase - Escoamento misto. A superfície livre do lençol delimita dois domínios de escoamento, um em meio poroso não saturado e outro em meio poroso saturado pelo próprio lençol d'água. Neste momento o lençol poderá reagir de duas maneiras: se a transmissividade do meio é elevada a vazão da água que infiltra não altera o nível do lençol; se a água que infiltração for significativa em relação ao lençol há a formação de um domo de pressão sob a estrutura de infiltração, neste caso, o funcionamento da estrutura dependerá do que ocorre nas zonas saturada e não saturada.

3믈 Fase - Escoamento horizontal em meio saturado. Sob determinados parâmetros o esquema da $2^{\underline{a}}$ fase pode evoluir para um regime de escoamento permanente. Quando o domo de pressão atinge o fundo da estrutura ( quando é estabelecido um equilíbrio) o escoamento passa a ocorrer em meio saturado e passa a funcionar como um dispositivo de injeção (alimentação) e não mais de infiltração.

FASE 1

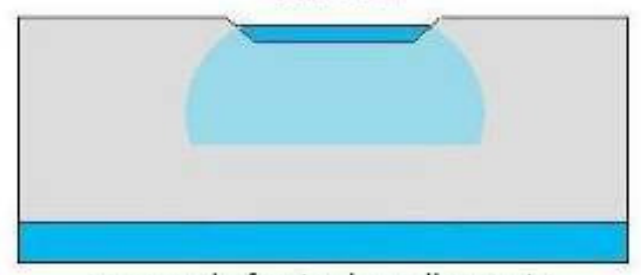

avanço da frente de molhamento

FASE 2

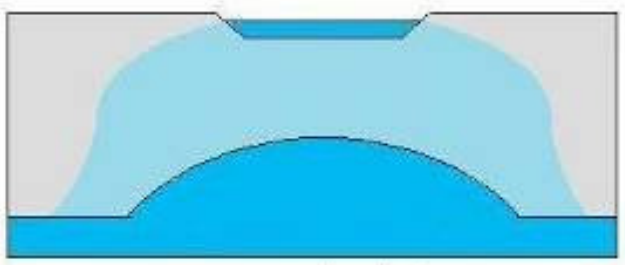

escoamento misto

FASE 3

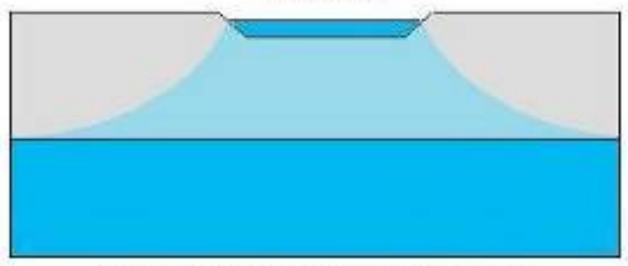

escoamento em meio saturado

Figura 5 - Diferentes fases de infiltração de um dispositivo de drenagem (Burgéap, 1991) 


\subsection{Considerações sobre a Colmatação}

Nas considerações de Baptista \& Nascimento (2005), a colmatação de uma estrutura de infiltração possui como causa básica a deposição de material particulado de finos no interior da estrutura preenchendo os vazios do meio poroso. As partículas maiores ficam retidas nas camadas superiores ao passo que as menores vão sendo carreadas para as partes mais profundas. De maneira geral esse é o fenômeno que faz com que o meio poroso perca através do tempo sua capacidade de condutividade hidráulica de maneira lenta e progressiva.

Podem ser associados a colmatação o desenvolvimento de algas, plânctons, fitoplânctons e de bactérias que podem, associadas ou não, contribuir para a diminuição da capacidade de infiltração da estrutura.

No entanto, o fenômeno da colmatação, contribui para a retenção de poluentes uma vez que, o meio poroso, quando passa a ter seus vazios preenchidos, torna a filtração mecânica mais eficaz A superfície e o tempo de contato aumentam e a retenção físico-química é então favorecida.

Em longo prazo, a infiltração de águas pluviais na estrutura pode tornar-se nula, uma vez que o sistema perde sua função drenante e passa a comportar-se como estrutura impermeável ou de retenção sem exutório. Assim, pois, a colmatação está diretamente ligada à vida útil do pavimento ou do meio poroso. 


\section{PAVIMENTOS PERMEÁVEIS - DESCRIÇÃO}

O termo pavimento aplica-se, de forma genérica, a qualquer tratamento ou cobertura da superfície que tem como finalidade suportar qualquer tipo de tráfego.

O pavimento permeável é aquele que possui porosidade e permeabilidade significativamente elevada de maneira a influenciar a hidrologia e causando algum efeito positivo ao meio ambiente.

Pavimentos cujo teor de vazios é baixo, e que possuam baixa taxa de infiltração de água não são considerados porosos.

Ferguson, Bruce K. (2005), compara a proporção de superfícies cobertas em relação à área potencialmente viável para execução de pavimentos em determinadas zonas de uso, com o objetivo de determinar locais para a aplicação de pavimentos permeáveis.

Citando Cappiella \& Brown (apêndice D, 2001) num estudo realizado para a região de Chesapeake Bay - Maryland - EUA foram analisados três tipos de uso (estabelecimentos comerciais como lojas, prédios de apartamento e casas) e a porcentagem da superfície coberta em relação a três tipos de área elegível para a execução de pavimentos (no caso, ruas, calçadas e estacionamentos).

Apresentou-se estudo de três lotes de igual tamanho incluindo áreas externas como passeios e ruas em três diferentes tipos de uso, a análise apenas considerou a porcentagem de projeção em planta destas áreas.

A Figura 6 apresenta os resultados dos estudos desenvolvidos. 

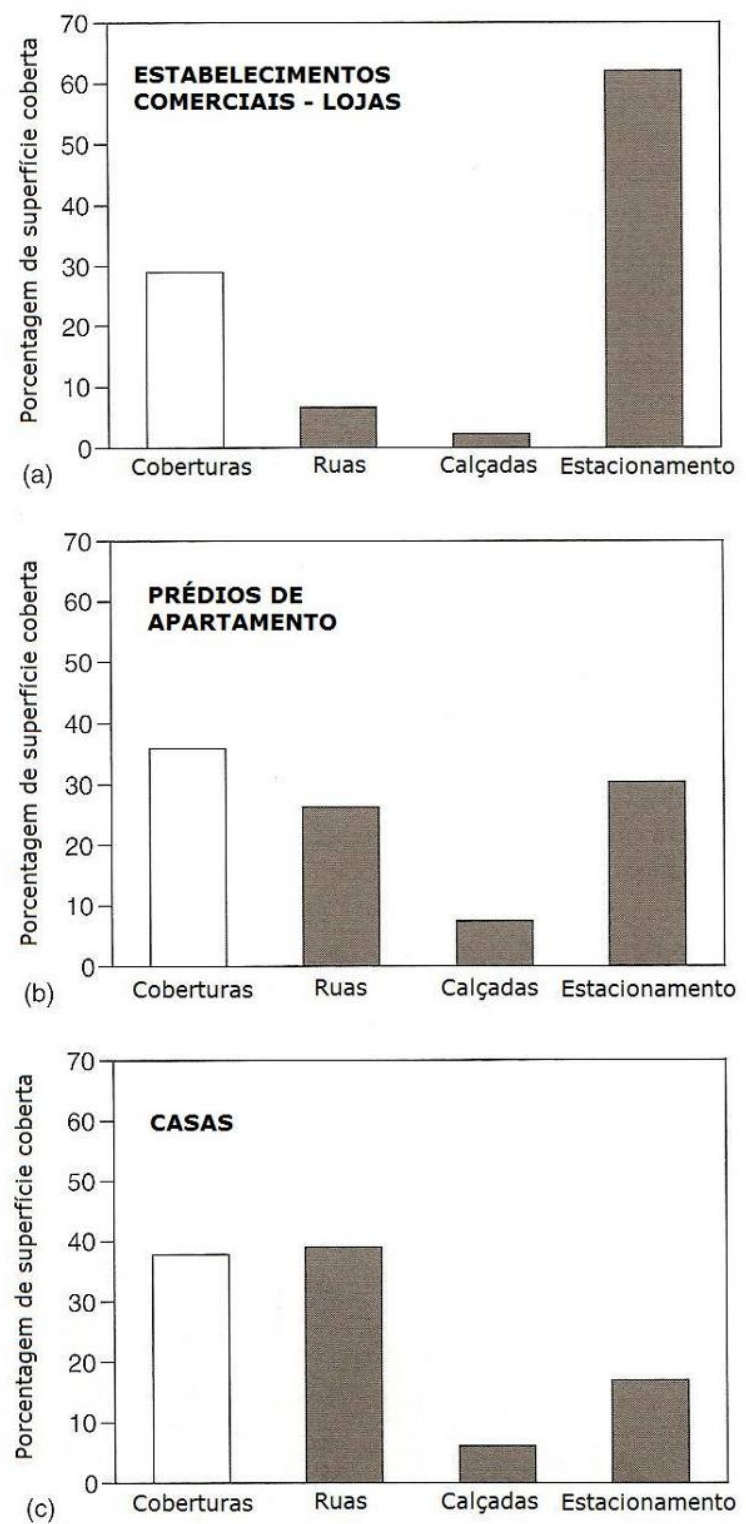

Figura 6 - Tipos de cobertura e área pavimentável em três categorias de uso (adaptado do apêndice D, Cappiella \& Brown, 2001)

Nos três gráficos, as áreas cobertas ou edificadas (coluna branca), representam aproximadamente 1/3 das áreas, ao passo que as áreas onde a pavimentação pode ser aplicada ocupam os outros $2 / 3$.

- Zonas de uso comercial (estabelecimentos comerciais ou lojas)- áreas de estacionamento representam a maior parte da superfície coberta. Calçadas e ruas não possuem relevância. Alguns pontos dos estacionamentos não recebem cargas significativas que possam comprometer a estrutura, em sua maior parte estão submetidos a tráfego leve e ligeiramente médios sendo esses pontos elegíveis para aplicação de pavimentos permeáveis. 
- Zonas de uso predial (prédios de apartamentos) - as áreas de estacionamento são proporcionais as áreas de ruas. As calçadas e a maior parte do estacionamento recebem baixo volume de tráfego e pouco carregamento, sendo também elegíveis para a aplicação de pavimentos permeáveis, porém as ruas podem receber diferentes tipos de carregamento variando de lugar para lugar.

- Zonas de uso residencial (casas) - a área de estacionamento, refere-se a garagens e locais de manobra de veículos, as ruas recebem apenas de tráfego local e calçadas são para uso de pedestres; esses três tipos de pavimento sofrem pouca ação de carregamentos e repetição de carga dinâmica ou estática, sendo portanto, elegíveis para a aplicação de pavimentos permeáveis, sem maiores conflitos estruturais.

Normalmente, os pavimentos e as obras de pavimentação, são tratados como estruturas que devem trabalhar secas sem a interferência de água. Adotam-se, portanto, sistemas que sejam impermeáveis, ou seja, que não permitam que a umidade dos solos seja um fator negativo quanto a redução da capacidade mecânica à compressão da estrutura e do comportamento físico das camadas de suporte e, dentre outros, a degradação do revestimento com a abertura de trincas e posterior formação de panelas ou outras patologias típicas da infiltração de água no interior da estrutura.

Pavimentos permeáveis fogem em princípio a definição acima, pois, diferentemente dos pavimentos convencionais asfálticos ou não, possuem estrutura simpática a absorção de água e, portanto, favorável ao molhamento de suas camadas inferiores.

A construção de pavimentos permeáveis visa contemplar um apelo à drenagem urbana. Tratando-se de dispositivo de infiltração, atua como técnica alternativa para o aumento da permeabilidade do solo urbano, tornando-se uma ferramenta de drenagem. 
Ocorre, pois um paradigma a ser considerado uma vez que os órgãos responsáveis pela drenagem preconizam sistemas voltados a infiltração das águas ao passo que órgãos responsáveis pela pavimentação procuram preservar as camadas em estado seco visando a estabilização estrutural e conseqüente aumento na capacidade de carga sobre o leito carroçável.

A França foi país pioneiro na aplicação de pavimentos com estrutura porosa no final da década de 40, porém, como os ligantes asfálticos não eram bem estudados até então, a estrutura rompia-se pela baixa adesividade ligante-agregado, não conferindo capacidade de carregamento ao revestimento poroso. Somente no início dos anos 70, países como a própria França, Suécia, Estados Unidos e Japão voltaram a se interessar pelo método e a aplicá-lo em pequena escala (Azzout et al., 1994).

Nos Estados Unidos, um marco no uso de pavimento asfáltico permeável como redutor dos impactos ambientais foi a pesquisa realizada no início da década de 70 por Edmund Thelem e engenheiros do Instituto Franklin na Philadelphia que, com o apoio da U.S. Enviromental Protection Agency (EPA), utilizando o concreto asfáltico poroso para o controle de cheias em 1968. Alguns anos mais tarde, Field et. al., 1982, criaram manuais práticos de projeto e construção de concreto asfáltico permeável.

Com o passar dos anos, alguns trechos construídos com concreto asfáltico poroso sofreram colmatação e conseqüente declínio da taxa de infiltração. No entanto, recentemente, com aplicação de novas tecnologias e materiais mais apropriados, estão sendo desenvolvidos concretos asfálticos porosos com melhor desempenho hidráulico além de durabilidade e confiabilidade estrutural.

Citando Aciolli, L.A. (2005), pelo menos três fatores são significativos para a aplicação do pavimento permeável:

1. A crescente urbanização e seus problemas de infiltração, demandando estudos e desenvolvimento de soluções contribuintes a drenagem visando a mitigação das enchentes em grandes centros. 
2. A aplicação em rodovias com o intuito de reduzir o efeito de aquaplanagem e o "spray" em dias chuvosos garantindo maior segurança e dirigibilidade.

3. A aplicação em locais para diminuir o nível de ruído, uma vez que este tipo de revestimento permite que o som penetre pelos vazios levando a redução da emissão de ondas sonoras.

Desde 1978, a França, o "Ministère de l'Equipement" lançou um programa de pesquisa e desenvolvimento de soluções para amenizar o efeito das inundações. $O$ pavimento permeável destacou-se como uma das soluções mais interessantes, graças a sua facilidade de integração com o ambiente urbano, além do fato de poder ser usado como estrutura de reservatório de retenção dos picos de cheia (Acioli, L.A. 2005 apud Azzout et al, 1994).

Desta época em diante, o pavimento permeável passou a ser objeto de pesquisas resultando no desenvolvimento de técnicas de execução e métodos de aplicação em diferentes áreas da engenharia hidráulica e de pavimentos. 


\subsection{Tipos de Pavimentos Permeáveis}

Os pavimentos permeáveis são conhecidos como estruturas reservatório. De acordo com Rimbauld et al. (2002) e Acioli L. A. (2005), essa denominação refere-se às funções realizadas pela matriz porosa de que são constituídos:

- Função mecânica, associada ao termo estrutura, que permite suportar os carregamentos impostos pelo tráfego de veículos.

- Função hidráulica, associada ao termo reservatório, que assegura, pela porosidade dos materiais, reter temporariamente as águas seguido pela drenagem e, se possível, infiltração no solo do subleito.

Segundo Azzout et. al. (1994), os pavimentos permeáveis se caracterizam em quatro tipos: o pavimento pode possuir revestimento drenante ou impermeável e ainda ter a função de infiltração ou armazenamento. A Figura 7 ilustra os quatro tipos de pavimento com estrutura de reservatório.

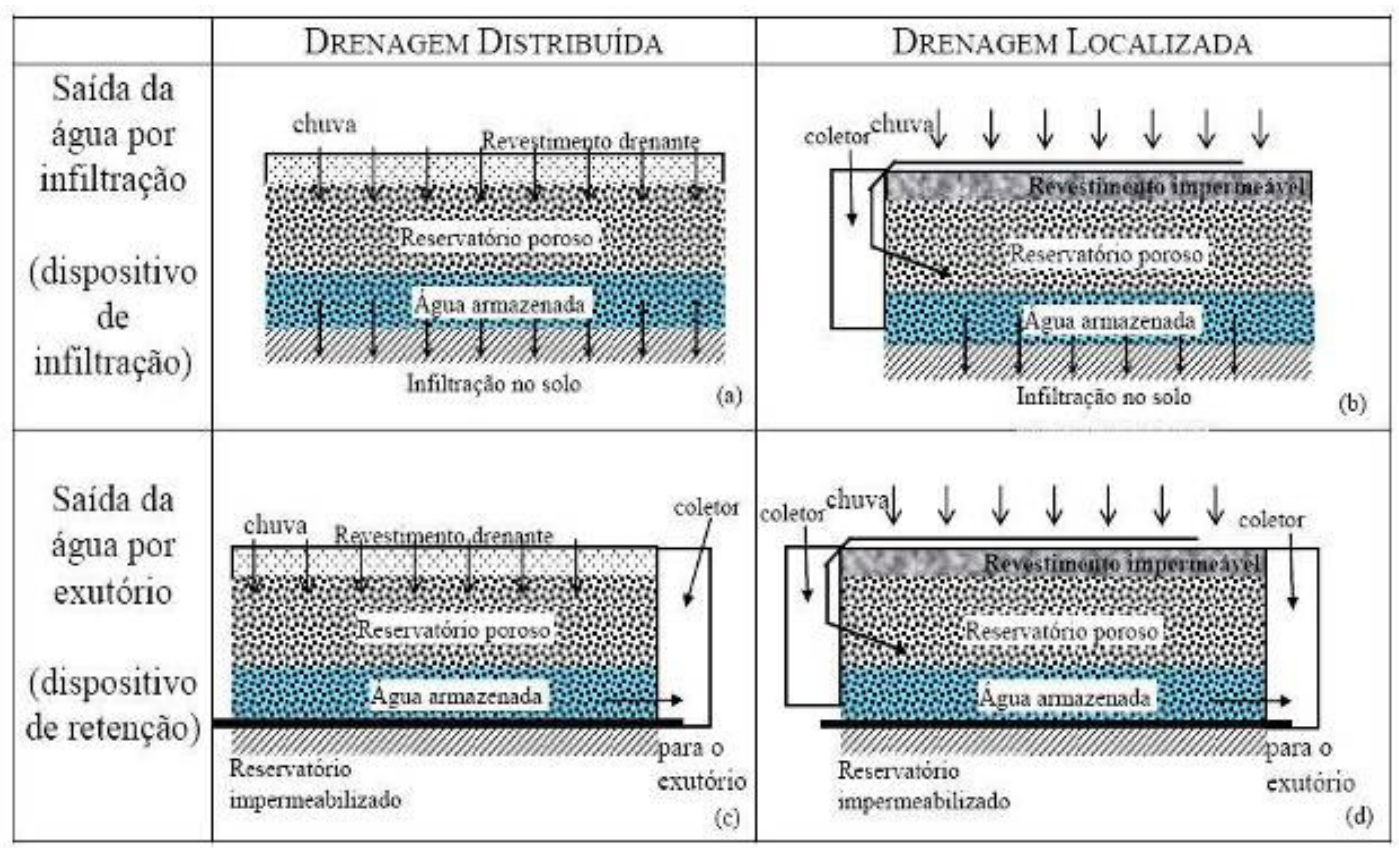

Figura 7 - Exemplo de diferentes tipos de pavimento com reservatório estrutural (extraído de Azzout ET AL., 1994 e Acioli, L. A. UFRGS, 2003). 


\subsection{Pavimentos voltados para a Infiltração}

Segundo Schueler (1987), o projeto de pavimentos permeáveis pode se encaixar em três categorias básicas:

- Sistemas de infiltração total: aqueles cujo único meio de saída é através da infiltração no solo. Neste, o dimensionamento das camadas de base e subbase deve ser tal que armazene o volume de uma chuva de projeto subtraído do volume que infiltra diretamente.

- Sistema de infiltração parcial: quando o solo do sub-leito não possui boa taxa de infiltração. Um sistema de drenagem deverá ser executado para promover a coleta da água que deixa de infiltrar.

- Sistema de infiltração para controle da qualidade da água: este sistema é utilizado para recolher o volume inicial do escoamento superficial que trás consigo a maior concentração de poluentes como a poluição difusa dos detritos espalhados aleatoriamente por toda a bacia hidrográfica e coletados para o sistema.

A Figura 8 apresenta o perfil dos três tipos de pavimentos permeáveis definidos por Schueler. 


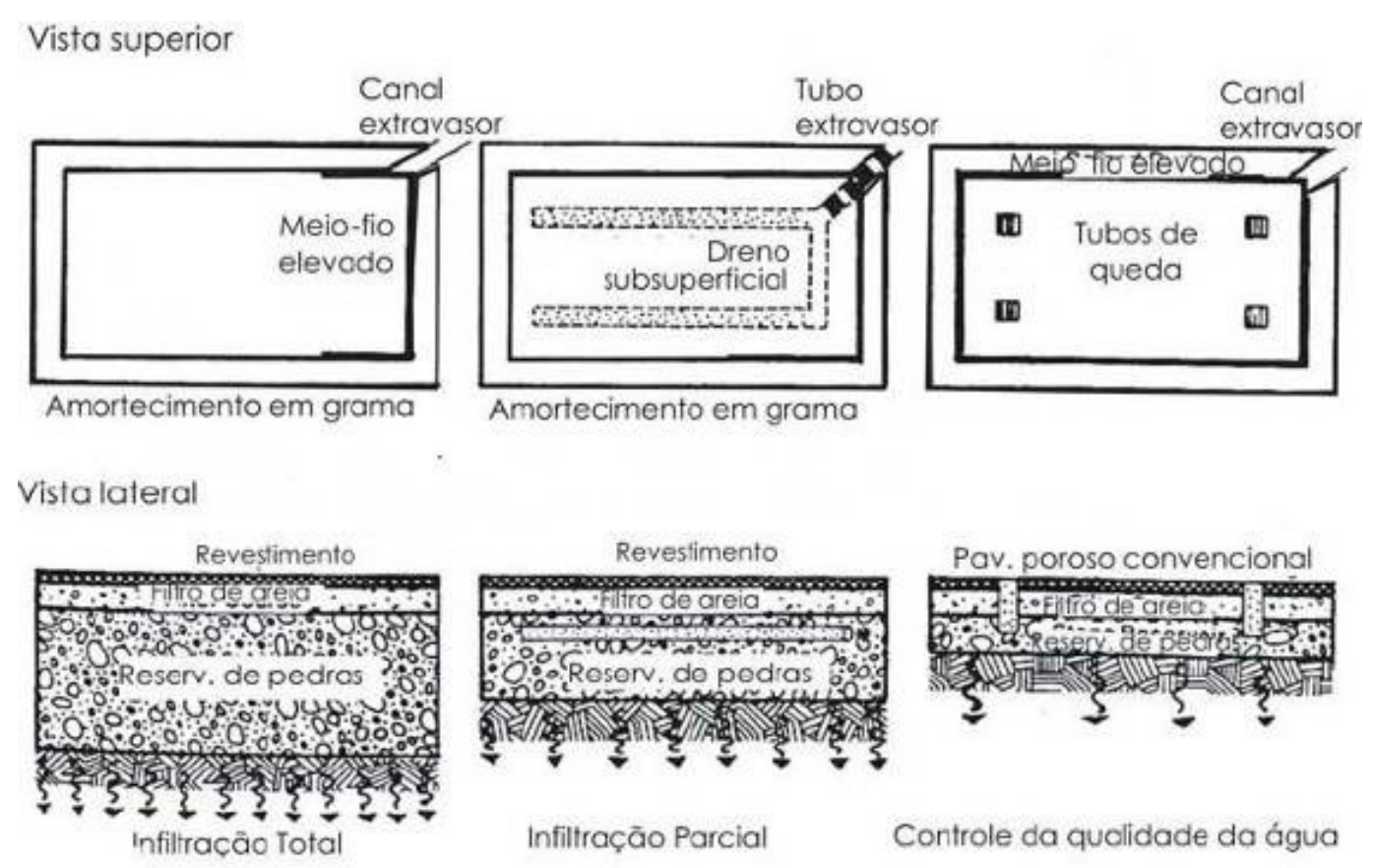

Figura 8 - Tipos de pavimentos permeáveis (adaptados de Schueler, 1987).

\subsection{Pavimentos voltados para a Detenção e Armazenamento}

Em áreas urbanas, as superfícies destinadas ao sistema viário e as de estacionamento podem ocupar espaços consideráveis, chegando a 30\% da área da bacia de drenagem, em áreas densamente ocupadas. Assim, a adoção de pavimentos permeáveis pode auxiliar no controle da produção do escoamento superficial no próprio sistema viário.

Basicamente podem ser identificados três níveis diferentes de atuação dos pavimentos porosos ou permeáveis no controle da produção de escoamento superficial.

- Pavimentos dotados de revestimentos superficiais permeáveis, possibilitando a redução da velocidade do escoamento superficial, a retenção temporária de pequenos volumes na própria superfície do revestimento e a infiltração para as camadas inferiores de parte das águas pluviais. 
- Pavimentos dotados de estrutura porosa, onde é efetuada a detenção temporária das águas pluviais, provocando o amortecimento de vazões e a alteração no desenvolvimento temporal nos hidrogramas.

- Pavimentos dotados de estrutura porosa e de dispositivos de facilitação da infiltração, onde ocorre tanto a detenção temporária das águas pluviais como também a infiltração de parte delas. Obtém-se o amortecimento de vazões, a alteração no desenvolvimento temporal nos hidrogramas e a redução dos volumes efetivamente escoados (Baptista, 2005).

A simples adoção de pavimentos com superfícies permeáveis por si só não representa ganho significativo para os sistemas de drenagem como é o caso dos revestimentos asfálticos tipo CPA (camada porosa de atrito), que apenas reduzem o escoamento superficial diminuindo o efeito de "spray" e aquaplanagem. Porém, sua combinação com a adoção de uma estrutura de pavimento porosa na base e subbase como, por exemplo, com o emprego de BGS (brita graduada simples) de graduação aberta, ou seja, tamanho mais uniforme dos agregados e pouco finos, permitirá a reservação temporária das águas pluviais em seu interior, com possibilidades de infiltração ou regulação de seu escoamento, melhorando significativamente o controle de escoamento e picos de cheias em zona urbana. 


\subsection{Princípio de Funcionamento e Tipos de Pavimentos}

Os tipos de pavimento com funções compensatórias em drenagem pluvial (Baptista \& Nascimento, 2005) podem ser assim classificados:

- Pavimentos com revestimentos permeáveis: possibilitam o acesso das águas pluviais às camadas inferiores do pavimento e efetuam ligeira redução do escoamento superficial.

- Pavimentos porosos de detenção: Desempenham o papel de reservatório temporário das águas pluviais, ou seja, com evacuação localizada, sem funções de infiltração, subdividindo-se em:

- Pavimentos porosos de detenção com injeção direta: dotados de revestimentos permeáveis.

- Pavimentos porosos de detenção com injeção indireta: dotados de revestimentos impermeáveis.

- Pavimentos porosos de infiltração: Desempenham dois papeis distintos, a reservação temporária e a infiltração das águas pluviais subdividindo-se em:

- Pavimentos porosos de infiltração com injeção distribuída; dotados de revestimentos permeáveis.

- Pavimentos porosos de infiltração com injeção localizada: dotados de revestimentos impermeáveis.

Cada um desses diferentes tipos de pavimentos apresenta estrutura específica quanto a sua utilização. 
Quanto a camada superficial, o revestimento pode ser impermeável, no caso de pavimentos convencionais novos, construídos em concreto de cimento Portland ou concreto asfáltico; semipermeável no caso de pavimentos em paralelepípedos, calçamento poliédrico ou blocos de concreto, e, por fim, permeável, em concreto asfáltico poroso tipo CPA, peças pré-moldadas de concreto poroso e blocos de concreto vazados.

A estrutura do pavimento não é muito diferente dos pavimentos clássicos, sendo geralmente constituída de brita e ligante. O volume de vazios desempenha papel importante para a determinação da capacidade de armazenamento.

A interface da estrutura do pavimento com o subleito ou solo adjacente deve ser realizada por meio da implantação de mantas geotêxteis adequadas quando 0 objetivo é assegurar a não colmatação da estrutura e garantir a função de infiltração.

Quando se objetiva a estanqueidade, como no caso de reservatórios, não deve haver interface da estrutura com o subleito, podendo ser utilizadas geomembranas ou lençóis plásticos de espessura adequada que impedem a infiltração d'água. 


\subsection{Componentes dos Pavimentos Permeáveis}

Tanto os pavimentos porosos como os convencionais são constituídos basicamente dos mesmos componentes. A Tabela 2 define alguns tipos dos componentes usados em pavimentação. Poucos pavimentos possuem todos os componentes listados, ao invés, cada pavimento deve ter uma combinação específica que atenda as suas próprias necessidades.

\begin{tabular}{|c|c|}
\hline & Terminologia aplicada a Pavimentos Porosos \\
\hline Terminologia & Definição \\
\hline Camada de Base & $\begin{array}{l}\text { Camada colocada abaixo da superfície de revestimento para aumenta a } \\
\text { espessura do pavimento. Pode ser simplesmente chamada de Base. }\end{array}$ \\
\hline Camada & Espaço ocupado entre dois tipos de materiais na estrutura do pavimento. \\
\hline Camada Filtrante & $\begin{array}{l}\text { Qualquer camada entre outras ou entre o pavimento e o subleito que detenha a } \\
\text { migração de partículas para os vazios da camada subjacente. }\end{array}$ \\
\hline Geomembrana & $\begin{array}{l}\text { Tecido impermeável geralmente plástico ou Polietileno de Alta Densidade } \\
\text { (PEAD) utilizada em sistemas impermeabilizantes. }\end{array}$ \\
\hline Geotextil & $\begin{array}{l}\text { Manta não-tecida de filamentos de polipropileno que possibilita a livre passagem } \\
\text { das águas de infiltração para o meio drenante. }\end{array}$ \\
\hline Pavimento & $\begin{array}{l}\text { Qualquer tratamento ou cobertura na superfície que suporte qualquer tipo de } \\
\text { tráfego. }\end{array}$ \\
\hline Sobrecamada & Camada aplicada sobre qualquer tipo de pavimento preexistente \\
\hline $\begin{array}{l}\text { Estrutura do } \\
\text { Pavimento }\end{array}$ & $\begin{array}{l}\text { Combinação de camadas de materiais colocadas sobre o subleito que } \\
\text { possibilitam o suporte mecânico do pavimento. }\end{array}$ \\
\hline Reservatório & $\begin{array}{l}\text { Qualquer parte do pavimento com capacidade de estocagem o condutividade de } \\
\text { água. O reservatório pode ser sobreposto ou combinado com outras camadas } \\
\text { do pavimento. Também chamado de Reservatório de Base, Camada Drenante } \\
\text { ou Colchão drenante. }\end{array}$ \\
\hline Sub-base & Camada colocada abaixo da Base a fim de aumentar a espessura do pavimento. \\
\hline Subleito & $\begin{array}{l}\text { Solo natural ou reforçado abaixo da estrutura do pavimento, responsável pela } \\
\text { absorção em última instância dos carregamentos. }\end{array}$ \\
\hline Revestimento & Camada do pavimento que recebe diretamente a carga de tráfego. \\
\hline
\end{tabular}

Tabela 2 - Terminologia geralmente aplicada a pavimentos porosos. 


\subsubsection{Revestimento, Base e Sub-base}

É muito comum a construção de pavimentos com duas camadas acima do subleito até 0 revestimento. Diferentes camadas podem ser otimizadas para propósitos especiais definidos para o pavimento. Além disso, a combinação de materiais em diferentes camadas pode tornar o pavimento mais econômico.

A Figura 9 ilustra a seção típica de pavimento com duas camadas entre o revestimento e o subleito.
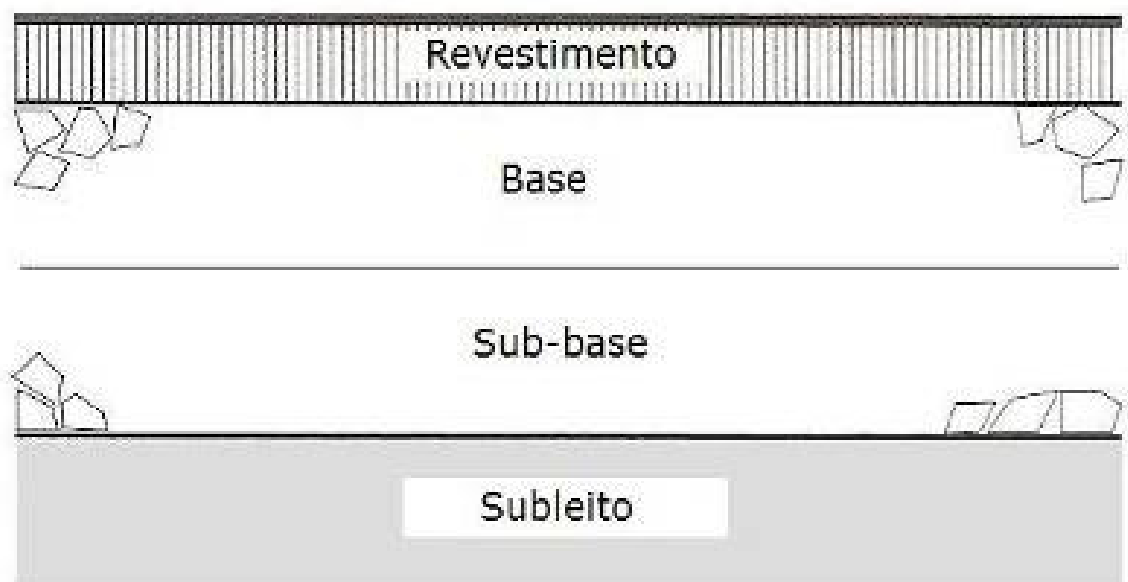

Figura 9 - Pavimento com duas camadas sob o revestimento

O revestimento recebe diretamente o carregamento de tráfego transferindo esforços para as camadas inferiores. De maneira geral o revestimento é economicamente mais caro por ser constituído de material resistente ao desgaste. Subjetivamente ao revestimento são atribuídas características tais como aparência e acessibilidade.

Uma ampla variedade de materiais pode satisfazer os requisitos de durabilidade, economia, aspecto e facilidade de execução dos revestimentos.

A camada da base confere espessura à estrutura do pavimento e se encarrega de distribuir o carregamento sobre o subleito. Caso seja necessário, a camada de sub base pode ser adicionada com a finalidade de aumentar a espessura ou para armazenar água no caso dos revestimentos porosos. 
Nos pavimentos com superfície impermeável, água não pode infiltrar em nenhuma parte da estrutura ou solo do subleito, mesmo que a base na estrutura de muitos pavimentos convencionais seja feita de material poroso. A superfície impermeável inviabiliza o funcionamento de um pavimento poroso.

\subsubsection{Sobrecamada}

Trata-se de qualquer camada de revestimento aplicada sobre qualquer tipo de pavimento preexistente. A Figura 10 mostra o tipo usual de sobrecamada de material poroso aplicada sobre revestimento convencional denso ou impermeável. Os departamentos de estradas de rodagem utilizam a sobrecamada como ilustrada, com o objetivo de drenar o escoamento superficial, melhorar a visibilidade, aumentar a aderência e reduzir o barulho e o reflexo. Isso faz com que as rodovias sejam mais seguras de dirigir além de aumentar a capacidade de transporte reduzindo os custos.

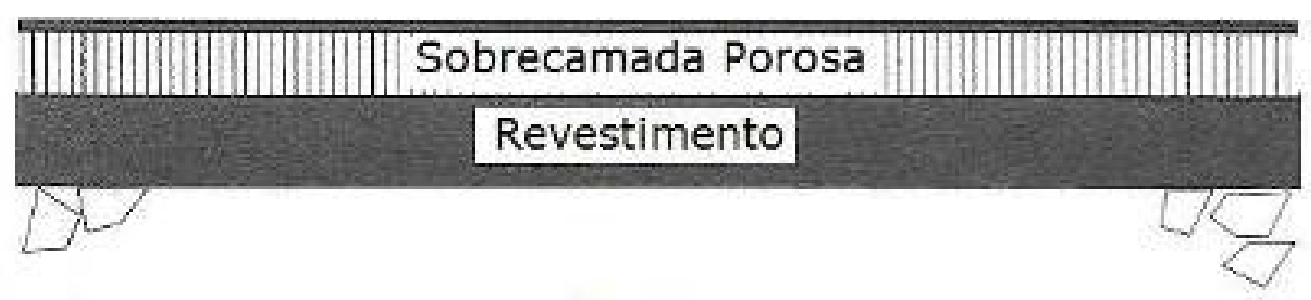

Base

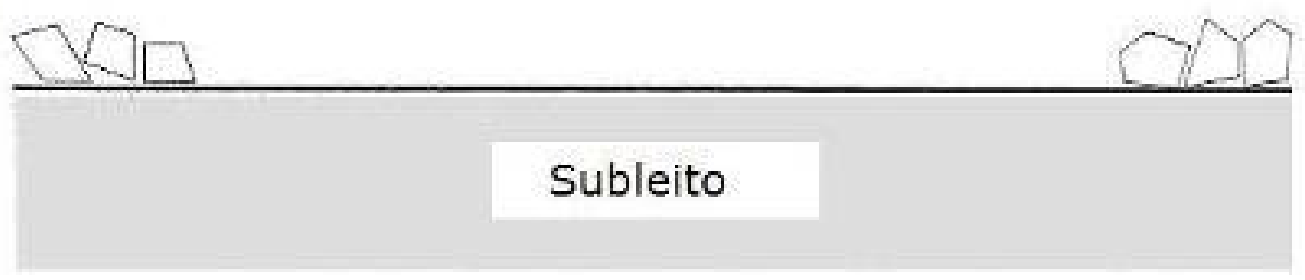

Figura 10 - Sobrecamada porosa sobre revestimento convencional

As sobrecamadas porosas, ou CPA (camada porosa de atrito) como são chamadas, são aplicadas apenas sobre determinados trechos de rodovias para eliminação dos efeitos da aquaplanagem e "spray" provocados pelos veículos em dias chuvosos. 


\subsubsection{Reservatórios}

Para pavimentos permeáveis, o reservatório é considerado como qualquer parte da estrutura que pode armazenar e transportar água para um exudório ou saída, através de tubo de drenagem ou filtrá-la diretamente para o solo. Inclui todo o material do pavimento que recebe água mesmo que ocasionalmente, podendo ser o mesmo material que possui funções estruturais.

O volume de água é estocado nos espaços vazios entre agregados. Pavimentos de camadas com índice de vazios que podem atuar como reservatório são preconizados por regulamentação específica como a da AASHTO (American Association of State Highway and Transportation Officials, 1993 - p. I-18) e do DNER (Departamento Nacional de Estradas de Rodagem).

Os reservatórios podem ser chamados também de Camada ou Colchão Drenante.

A água armazenada no pavimento poderá ser eliminada lentamente através de tubos laterais. A baixa velocidade de descarga retarda o pico de cheia, minimiza os efeitos da erosão além de reduzir os custos das estruturas dos sistemas de drenagem em dispositivos implantados à jusante.

Quando a água armazenada infiltra para o subleito, além dos benefícios acima, contribui adicionalmente para a recarga de aqǘferos aumentando o nível do lençol freático e o escoamento básico.

Toda água que passa através dos poros de qualquer camada de pavimento, naturalmente é filtrada e tratada pela atividade bioquímica dos microorganismos.

De maneira geral a estrutura de armazenagem que possui funções hidráulicas em determinada camada do pavimento é denominada de "Reservatório de Base", que poderá ser drenado por tubos em qualquer altura dividindo a base em dois segmentos; um que tem a função de escoar a água excedente de dentro do reservatório para fora da estrutura e outro segmento abaixo que retém a água para 
infiltração. Ambos os segmentos possuem função estrutural, porém o segmento de baixo também possui função hidráulica.

\section{- Reservatórios Nivelados ou Inclinados}

A Figura 11 ilustra como a configuração de um reservatório pode variar conforme a inclinação da superfície do pavimento. Para uma superfície nivelada, o reservatório será uma camada horizontal na parte inferior do pavimento (a), ao passo que em superfícies inclinadas poderá ser necessária uma camada adicional de base para compensar a inclinação (b).

Quando a camada inferior do pavimento for inclinada a água se dirigirá para o ponto mais baixo, limitando a capacidade do reservatório (c). Para compensar, a base próxima ao ponto mais baixo poderá ser executada de forma a aumentar o volume de armazenamento (d).

Superfície nivelada

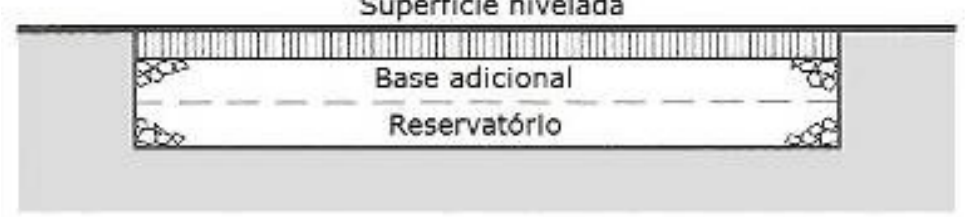

(a)

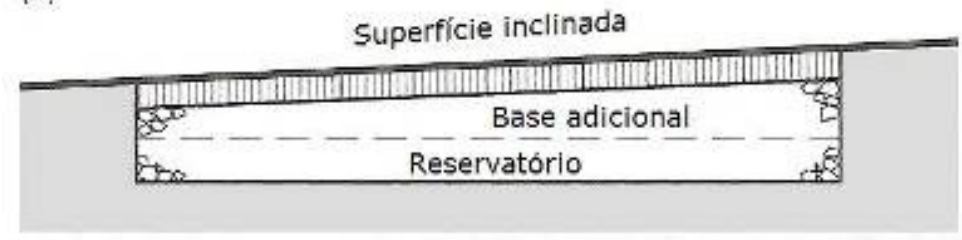

(b)

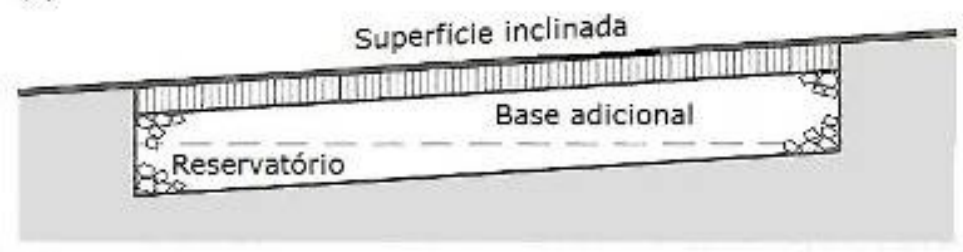

(c)

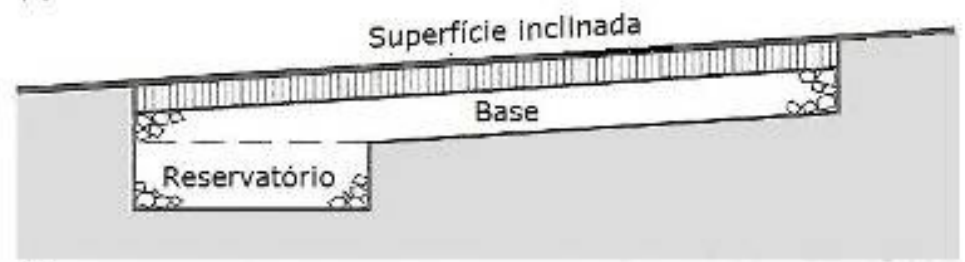

(d)

Figura 11 - Pavimentos com reservatórios em nível ou inclinados (Fergunson B.K.,2005). 


\section{- Reservatórios com Saída Lateral}

Tubos ou outros dispositivos implantados lateralmente podem servir de escape para a água que entra no pavimento atuando também como limitadores de profundidade e da duração da retenção na estrutura superior do pavimento. A capacidade de saída comanda a taxa de amortecimento. Alguns dispositivos de saída podem ser escolhidos em função dos custos de manutenção.

A Figura 12 mostra os arranjos possíveis para a implantação de dispositivos de saída na parte inferior do reservatório. Os drenos laterais permitem que quase a totalidade das águas sejam dirigidas para as laterais e escoadas não deixando que sejam infiltradas para o subleito. As águas podem ser captadas por drenos granulares (a), tubos perfurados (b) e (c) com ou sem estruturas que permitam 0 monitoramento ou manutenção.

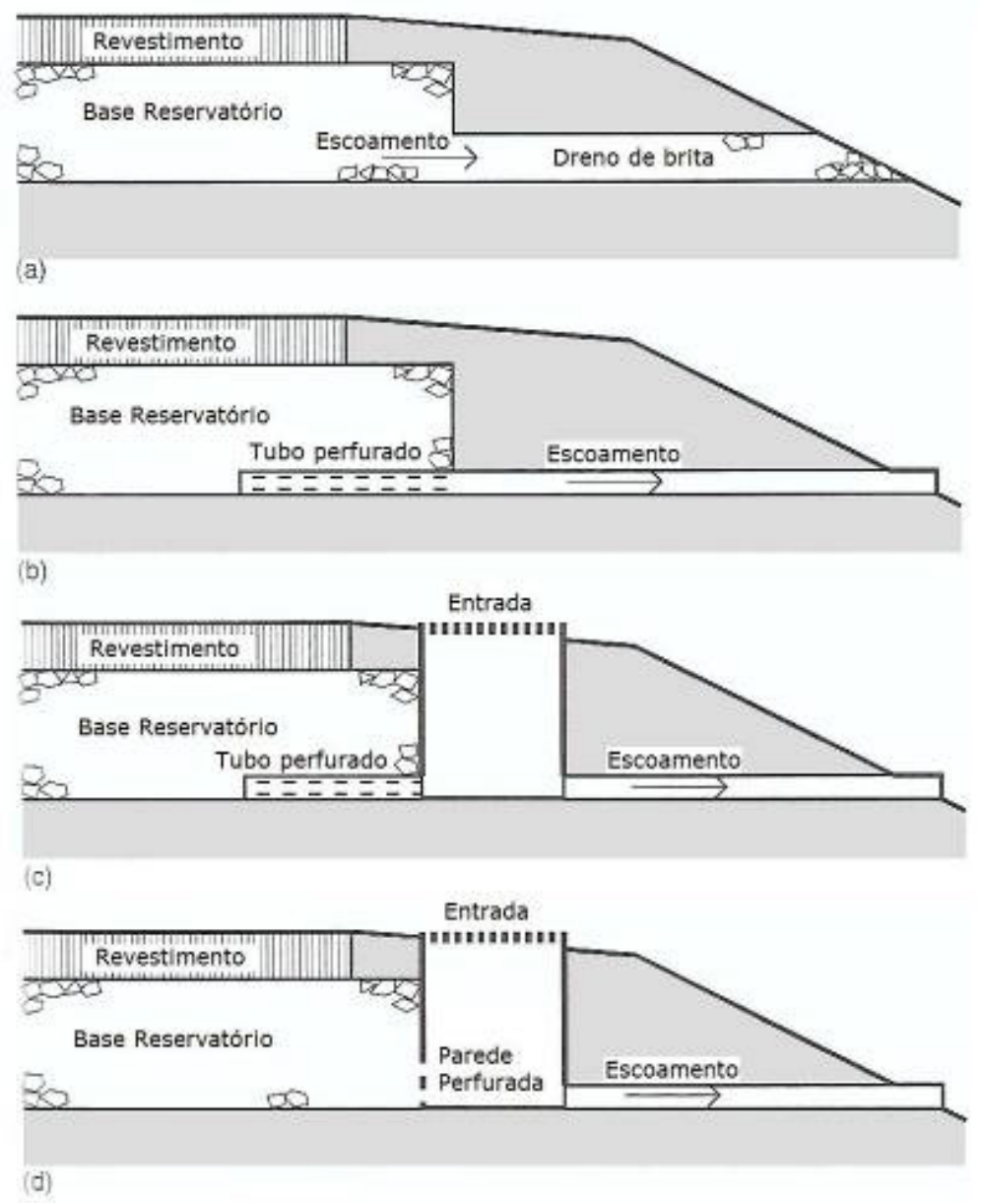

Figura 12 - Exemplos de dispositivos de descarga lateral localizados na parte inferior do Reservatório de Base (Fergunson B.K., 2005). 
A Figura 13 ilustra dispositivos de saída para o excesso de água que fica dentro do pavimento. O reservatório abaixo do tubo de saída lateral retém a água destinada a infiltração para o subleito (a), (b) e (c). Trincheiras de infiltração construídas longitudinalmente podem ser economicamente vantajosas $(d)$.

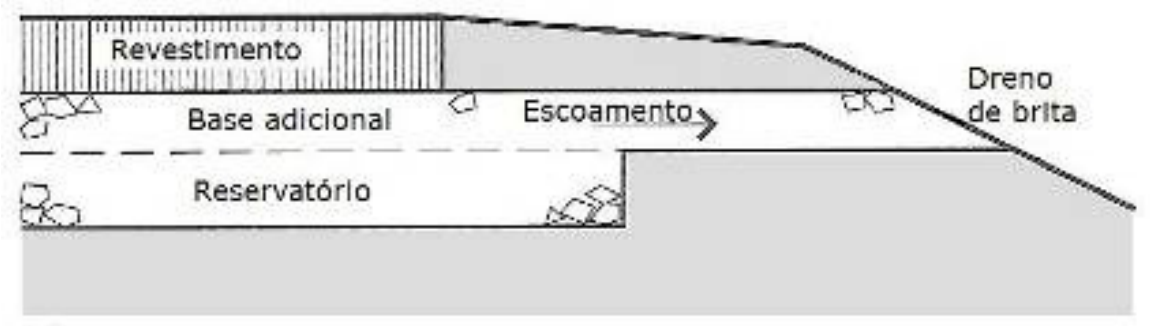

(a)

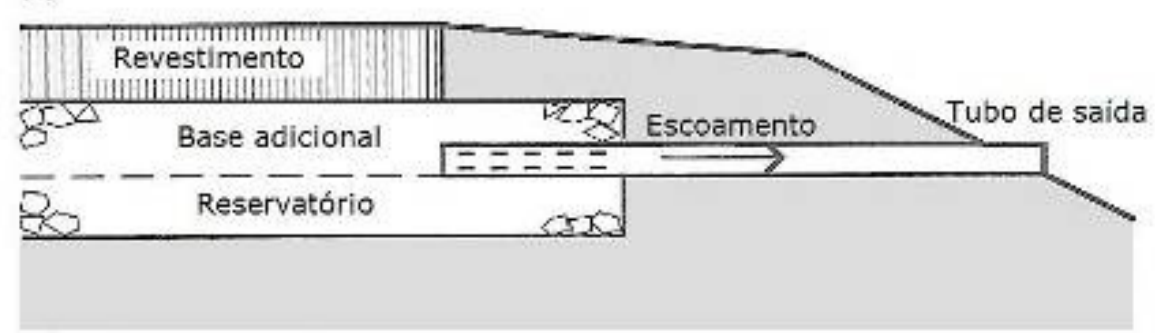

(b)

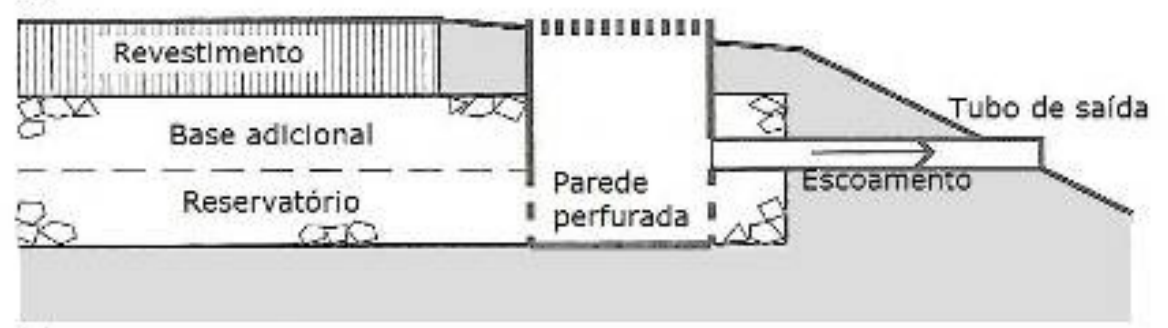

(c)

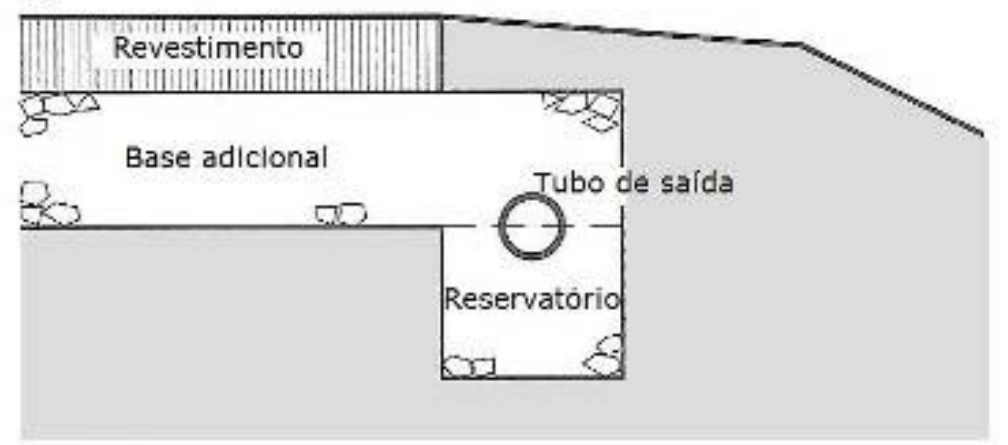

(d)

Figura 13 - Exemplos de dispositivos de descarga lateral localizados na parte superior do Reservatório de Base (Fergunson B.K., 2005). 
Na Figura 14, são mostrados dispositivos de saída para o escoamento superficial quando a água excede a capacidade de armazenamento do reservatório ou quando a taxa de infiltração direta para o solo é baixa gerando demora na absorção. Em casos assim, a água excedente sai pelo próprio pavimento em direção as laterais pela simples inclinação do terreno (a). Este arranjo é possível apenas em locais com baixa solicitação de carregamento de tráfego.

A execução de camada granular aflorante e ao longo do pavimento (b), permite que a superfície do revestimento fique protegida do excesso de água no reservatório que ocasionalmente pode extravasar.

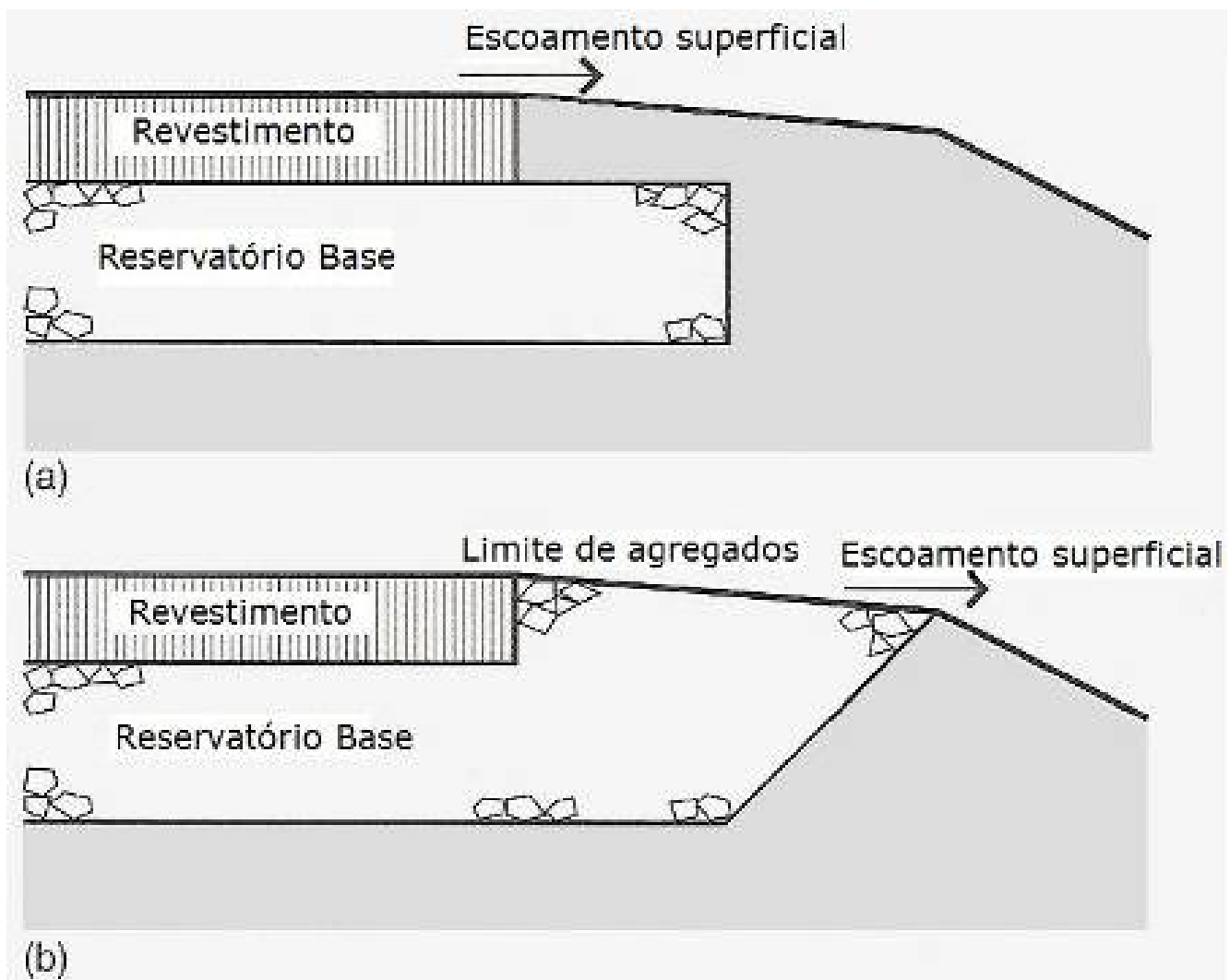

Figura 14 - Exemplos de dispositivos que permitem o escoamento superficial e protegem o pavimento (Fergunson B.K., 2005). 


\subsubsection{Geotêxteis}

Material aplicado entre duas camadas ou entre a camada de base e o subleito com a finalidade de separação de seus materiais. A separação é necessária para manter a porosidade evitando o carreamento de partículas para outra camada além de manter a integridade estrutural das camadas. Trata-se de manta não-tecida de filamentos de polipropileno que possibilita a livre passagem das águas de infiltração para o meio drenante ou camada adjacente. Alternativamente a separação entre camadas pode ser feita de material granular selecionado de tamanho intermediário. Os geotêxteis são permeáveis e inibem a movimentação de pequenas partículas atuando como filtros. Em alguns pavimentos o geotêxtil proporciona ainda resistência às tensões de deformação.

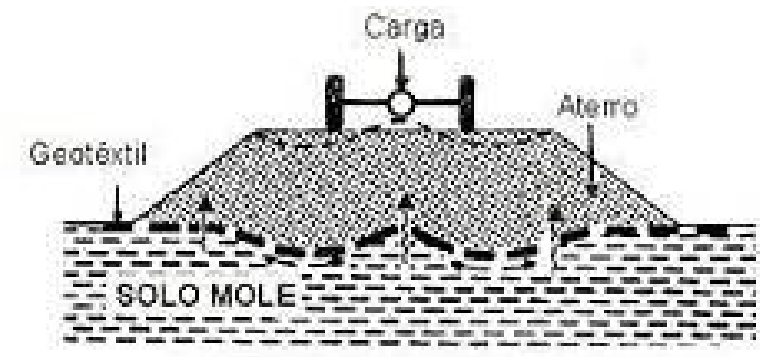

Aterro sobre Solo Mole

(Curso Básico de Geotéxteis - CTG - ABINT)

Figura 15 - Aplicação de geotêxteis em pavimentos deformáveis (ABINT, 1999)

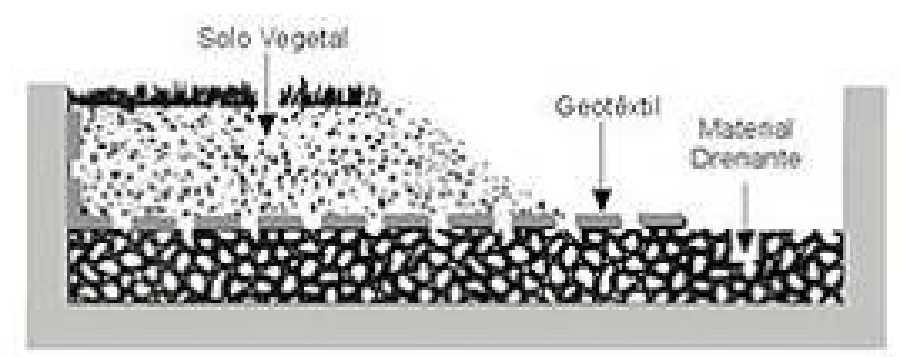

Jardim suspenso/floreira com colchăo drenante e geotêxtil utilizado como separaçăo e filtro (Curso Básico de Geotéxteis - CTG - ABINT)

Figura 16 - Aplicação de geotêxtil como separação e filtro (ABINT, 1999). 


\subsubsection{Geomembranas}

Alguns pavimentos porosos têm sua parte inferior revestida com o propósito de impedir a penetração de água para o subleito $O$ termo técnico para extensos lençóis de plástico resistente é "geomembrana" que se aplica a um tecido impermeável geralmente plástico ou Polietileno de Alta Densidade (PEAD) utilizado em sistemas impermeabilizantes. Quando um solo possui material quimicamente tóxico a geomembrana impede a contaminação das águas ao meio ambiente. A função hidráulica de um pavimento cuja camada inferior da base é revestida limita-se a detenção e ao tratamento qualitativo das águas, não a infiltração.

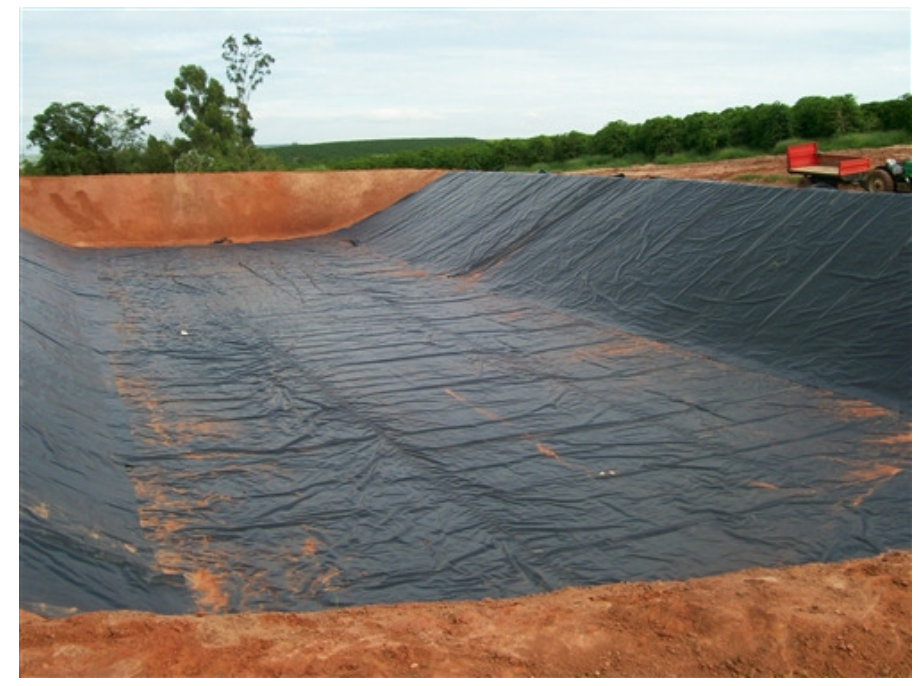

Foto 3 - Reservatório revestido com geomembrana (revista Engenharia edição 547, 2001).

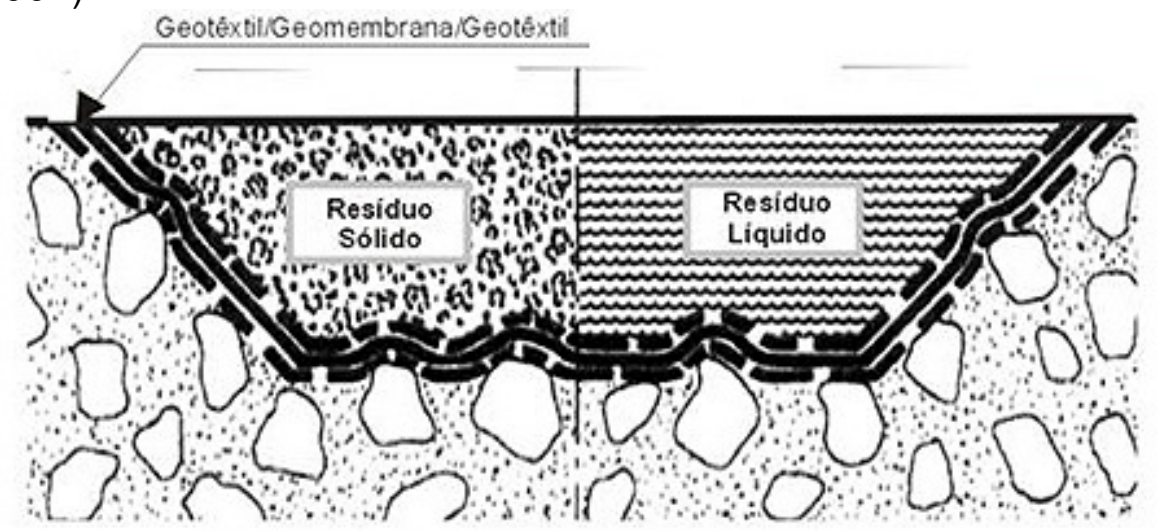

Geotêxtil como proteçăo da geomembrana em solos com afloramento de rocha em valas de resíduos

Figura 17 - Aplicação de geomembrana conjugada com geotêxtil em reservatórios (ABINT, 1999). 


\subsection{Materiais usados em Pavimentos Permeáveis}

Fergunson B.K., 2005, classificou genericamente os pavimentos permeáveis em famílias de materiais. No presente trabalho selecionamos sete principais, quais sejam:
1) Agregados
2) Gramíneos
3) Geocélulas plásticas
4) Concreto poroso
5) Blocos vazados
6) Blocos intertravados de concreto
7) Concreto asfáltico poroso

A seguir, descreve-se sucintamente cada um desses materiais.

\subsubsection{Agregados}

Agregados em pavimentos porosos podem ser tratados como quaisquer materiais particulados tal como cascalho, pedregulho, pedra britada, RDC (resíduo de construção civil), material reciclado de blocos de concreto ou granito em decomposição dentre outros. A gradação uniforme deve resultar num volume de vazios da ordem de 30 a $40 \%$, constituindo material extremamente permeável ao ar e a água. Além de ser o material mais utilizado na base e sub base dos pavimentos, é também o principal componente dos concretos porosos. É utilizado para preenchimento de blocos vazados, grelhas e geocélulas. Possui vantagens econômicas e ambientais por ser o material mais abundante e natural encontrado. 


\subsubsection{Gramíneos}

Uma superfície gramada pode suportar tráfego de pedestres e algum tráfego veicular. A permeabilidade dos gramíneos é maior quando não compactados por excesso de trafego. A transpiração desse tipo de revestimento reduz a formação de ilhas urbanas de calor. Quando plantadas sobre argila plástica possuem maior possibilidade de serem danificadas pela passagem repetitiva que empurra a argila para dentro da placa de grama e colmata a superfície. São muito usadas em passeios e áreas de estacionamento que não sejam utilizados com freqüência. Com a ajuda de grelhas plásticas, geocélulas e blocos vazados de concreto podem suportar carregamentos maiores de tráfego.

De qualquer maneira requer manutenção constante com replantio, espalhamento de terra, irrigação e uso de fertilizantes. Deve-se escolher o tipo de gramíneo especifico para o clima do local e para a insolação visto que alguns tipos crescem melhor à sombra que outros.

\subsubsection{Geocélulas Plásticas}

São constituídas de tiras de polietileno de alta densidade (PEAD), soldadas entre si, que quando abertas formam células contíguas tridimensionais semelhantes a uma colméia que pode ser preenchida com areia, brita concreto ou solo conforme for a disponibilidade e a finalidade. Foi concebida originalmente com o objetivo de fazer da areia um material de construção. Sua utilização pioneira se deu na construção de estradas de acesso a praias e desertos. Pode ser usada em várias aplicações como suporte de cargas na estabilização de pavimentos rodoviários e ferroviários, em estruturas de contenção de terra e na prevenção e controle da erosão de taludes. $\mathrm{Na}$ maioria dos modelos, as tiras de plástico ocupam uma pequena parte da área de superfície permitindo, quando preenchidas com material poroso de alta permeabilidade, controle térmico e apelo visual ecológico no caso de preenchimento com grama vegetal. 

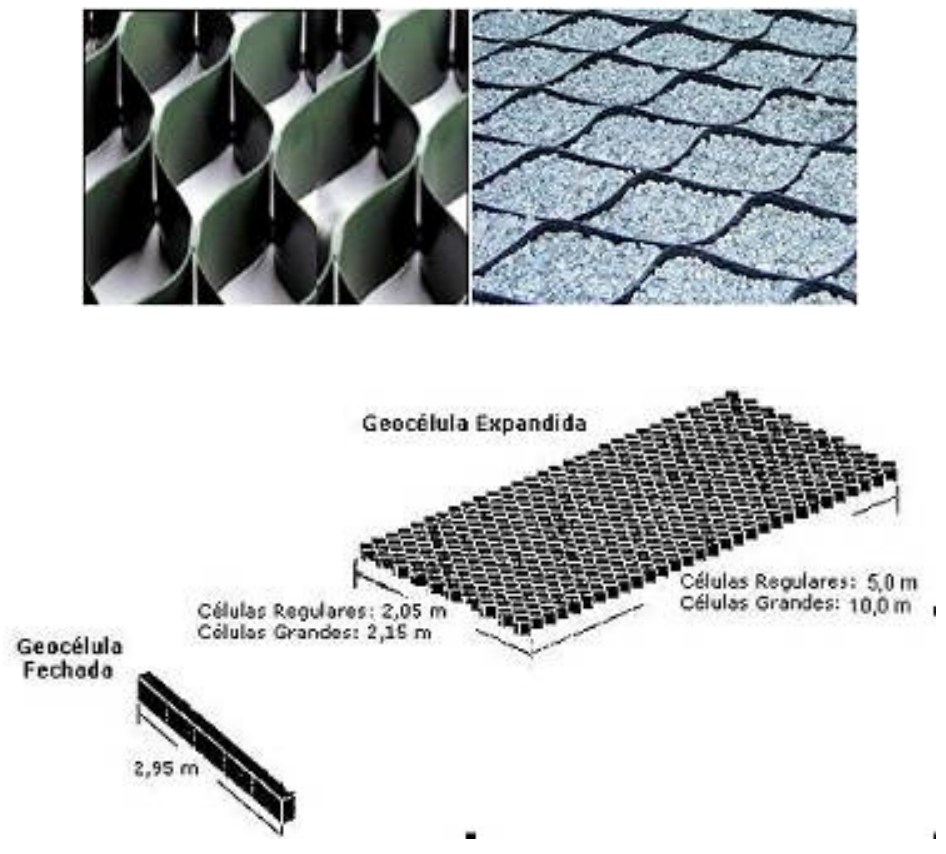

Figura 18 - Geocélulas plásticas (ABINT, 1999)

\subsubsection{Concreto Poroso}

Trata-se de uma sutil diferença na mistura convencional de cimento Portland, pois os agregados devem no caso possuir gradação uniforme. Quando aplicado sobre as camadas da estrutura do pavimento, resulta numa placa rígida. Tem custo alto de fabricação no início, mas ao longo do tempo esse custo vai diminuindo. Não deve ser aplicado sobre subleito fraco, pois a movimentação da estrutura como um todo poderá ocasionar trincas (Fergunson B.K., 2005).

O concreto poroso é apropriado para suportar carregamentos de baixo volume de tráfego como em calçadas e áreas de manobra de estacionamentos residenciais, além de suportar carga de tráfego médio em estacionamentos comerciais e ruas residenciais. Poderá sob condições específicas de dimensionamento receber carregamentos de tráfego pesado. $\mathrm{O}$ concreto poroso quando acabado tem grande permeabilidade. Como desvantagem, há sempre a possibilidade de colmatação e constantes gastos com a manutenção e limpeza. 


\subsubsection{Blocos Vazados}

Unidades de blocos de concreto desenhados com células ou aberturas que permitem o preenchimento com agregados ou gramináceos. São implantados lado a lado resultando numa superfície semelhante a uma grelha ou desenho simétrico em ângulo reto ou diagonal. Como pavimento não são relativamente econômicos. Muitos tipos são duráveis e possuem considerável vida útil. A maior parte é capaz de suportar bem a carregamentos pesados.

Não existem muitas empresas que fabricam esse tipo de material de revestimento, por isso seu custo é alto em relação a outros materiais inclusive em comparação aos blocos de concreto intertravados.

Para adquirir boa resistência a compressão as peças são executadas em concreto de no mínimo $25 \mathrm{MPa}$ (ABNT 9780/87 e ABNT 9781/87). Devem trabalhar solidamente unidas e confinadas a bordas de concreto. Em termos de porosidade e condutividade hidráulica são excelentes.

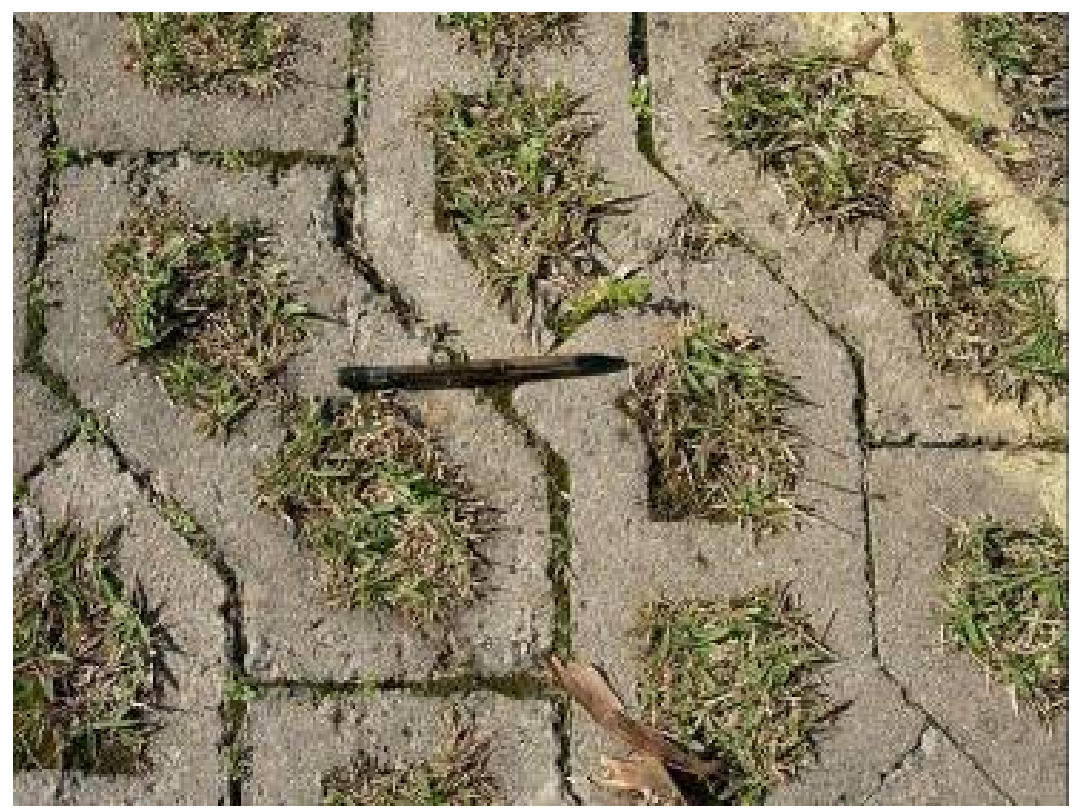

Foto 4 - Blocos de concreto pré-moldado vazados 


\subsubsection{Blocos Intertravados de Concreto}

Esse tipo de revestimento permite tráfego de vários tipos. Blocos maciços de concreto, alinhados lado a lado são os mais comuns. São geralmente assentados sobre camada de areia que confere ao conjunto porosidade e permeabilidade.

Muitos blocos possuem boa durabilidade e resistência permitindo vida útil mais longa e conseqüente economia sob o aspecto custo benefício. Alguns blocos podem suportar tráfego pesado, porém são relativamente caros quando comparados a outros pavimentos. São sensíveis as deformações longitudinais assim como as deformações na base e no subleito. Quando assentados devem ser confinados a bordas rígidas que impedem que as peças fiquem livres de tensão e possam se soltar. Geralmente são limitados nas suas extremidades a sarjetas ou vigotas de concreto.

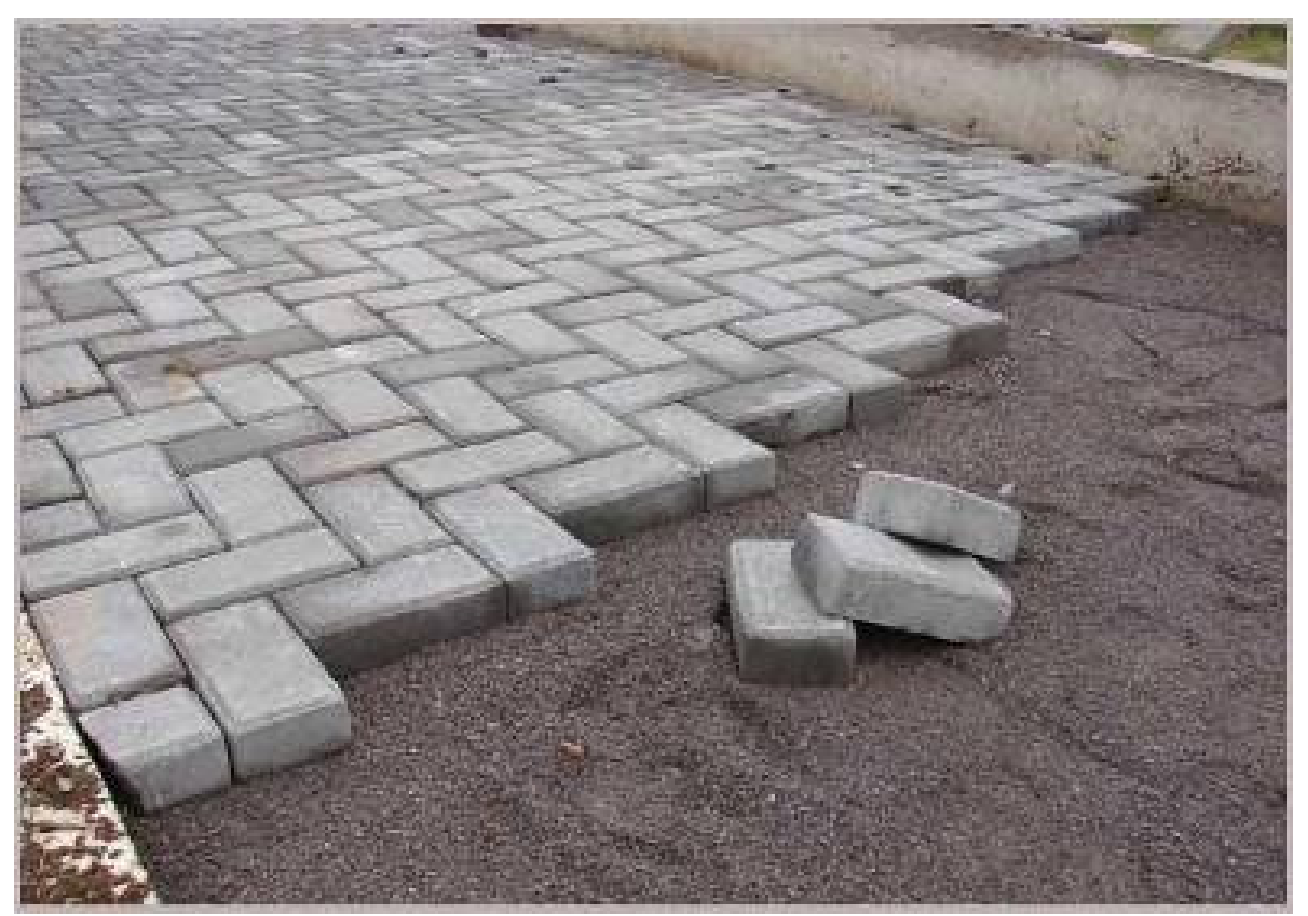

Foto 5 - Blocos de concreto intertravados assentados sobre berço de areia 


\subsubsection{Concreto Asfáltico Poroso}

É a mistura entre ligante betuminoso e agregados de tamanho uniforme. Concreto asfáltico de maneira geral é bem conhecido como material relativamente barato e de diversas aplicações. O concreto asfáltico poroso é uma variação do convencional com a propriedade de ser permeável, entretanto, é susceptível a colmatação causada pelo próprio ligante. Onde o ligante é muito fluido ou quando a união entre ligante e agregado é fraca, o ligante betuminoso pode escorrer gradualmente da superfície do revestimento através dos poros até acumular-se em um ponto dentro da estrutura deixando as partículas da superfície segregadas.

$\mathrm{Na}$ Europa e nos Estados Unidos muitos departamentos de estradas de rodagem tem desenvolvido tecnologias para estabilizar o ligante betuminoso visando assegurar vida útil mais longa ao concreto asfáltico poroso. A utilização de camadas de pavimento permeável deve atender as necessidades construtivas de rodovias seguras, bem drenadas e com boa aderência.

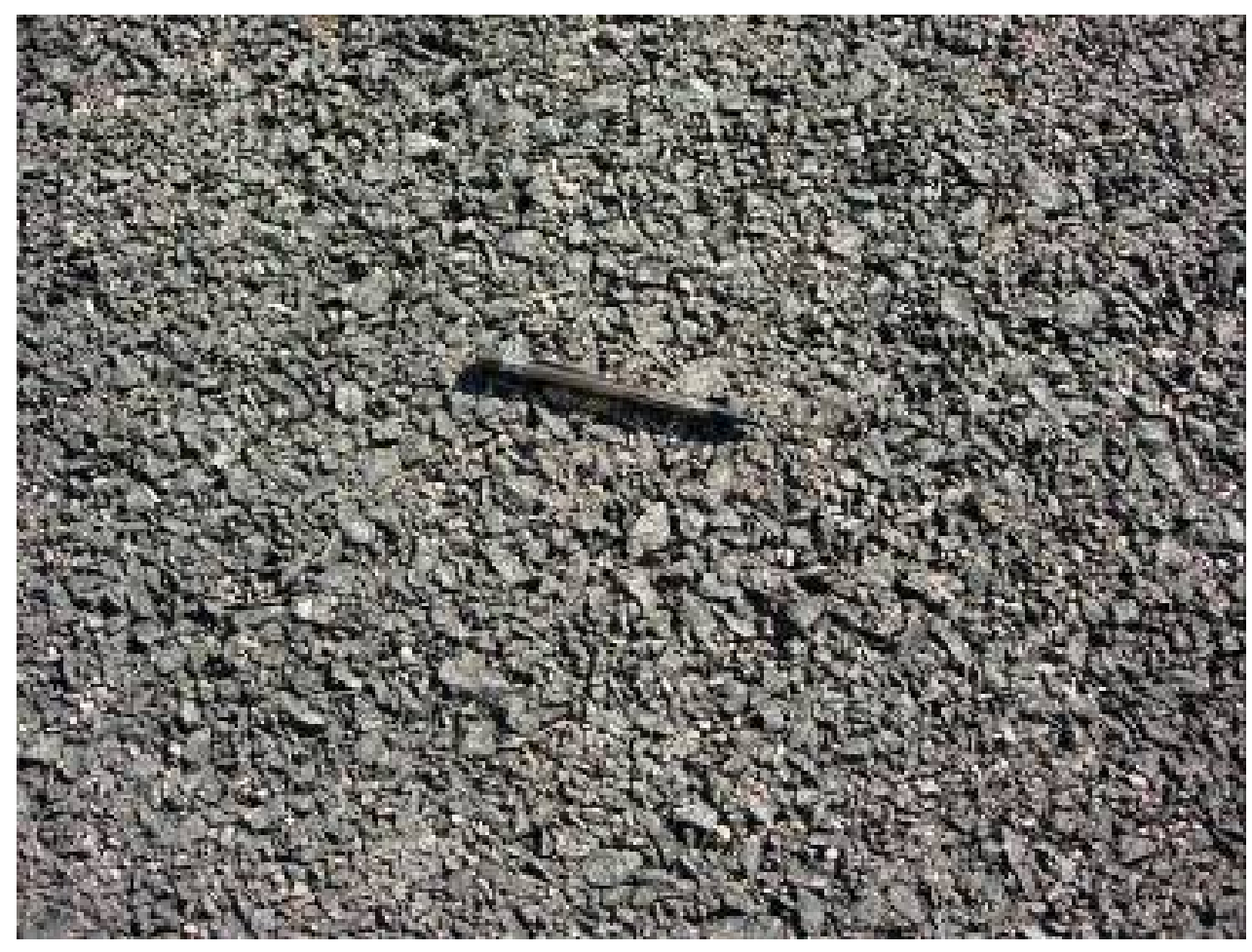

Foto 6 - Concreto Asfáltico Poroso 


\subsection{Estudo das Peças Pré-Moldadas de Concreto - PPC}

\subsubsection{Pavimentos Intertravados de Concreto}

\subsubsection{Histórico}

Blocos com a finalidade de pavimentação são utilizados há muito tempo na história da humanidade. Originariamente o material mais comum era pedra ou tijolos de barro. Após a $2^{\underline{a}}$ Guerra Mundial, algumas cidades européias foram reconstruídas tal como eram no período pré-guerra com ruas pavimentadas por blocos de pedra. Porém, pela dificuldade em se conseguir esse tipo de material, nessa época algumas companhias passaram a desenvolver tecnologia para a produção de blocos de concreto visando substituir com economia a malha viária sem perder, no entanto, características essenciais como resistência, baixa abrasividade, aderência, facilidade de execução além de custo de transporte das peças (Smith, 1999).

Nos Estados Unidos, ao mesmo tempo, a maioria dos pavimentos eram feitos de asfalto em função do desenvolvimento da indústria automobilística que demandava pavimentos mais suaves e de rolamento confortável além de permitir maior velocidade.

A indústria de blocos pré-moldados recebeu grande impulso na Alemanha no início da década de 60 e a tecnologia logo foi transferida para países como Inglaterra, Japão, Austrália, Nova Zelândia e África do Sul. Nos Estados Unidos, blocos de concreto passaram a ser largamente utilizados em projetos urbanísticos.

A partir dessa época, a indústria de blocos pré-moldados vem sendo o berço de enorme quantidade de pesquisas de novas tecnologias, como estudos de projetos de construção de pavimentos em blocos intertravados de concreto (Shackel, 1990) e pesquisas sobre a estrutura das peças de concreto para U. S. Army Corps of Engineers USACE, elaborada por Rollings e Rollings no início dos anos 90. 


\subsubsection{Características de uso dos Blocos de Concreto.}

Possuem juntas preenchidas com material granular poroso ou selante podendo até mesmo trabalhar simplesmente sem preenchimento.

Atuando como conjunto, formam uma superfície ao mesmo tempo porosa e permeável ao passo que suporta cargas de tráfego através da sua estrutura.

Quando devidamente executado, esse tipo de pavimento pode ser muito durável mesmo sob condições adversas e variáveis como chuva e temperatura sem perda da capacidade de suporte.

A maioria dos blocos de concreto são submetidos a controle de qualidade durante seu processo de fabricação, além disso, devem atender as normas e especificações técnicas preconizadas pela NBR 9780, NBR 9781, ABNT - Associação Brasileira de Normas Técnicas e ABCP - Associação Brasileira de Cimento Portland.

São produzidos em diferentes formatos e cores conferindo maior versatilidade estética.

Caso o berço de areia sobre o qual os elementos forem assentados apresente alguma anomalia como má compactação, alguns blocos poderão ser arrancados, porém sua reposição não é dispendiosa e relativamente simples.

As peças pré-moldadas de concreto (PPC) para pavimentação de vias urbanas, pátios de estacionamentos, entre outros estão regulamentadas pela Norma Brasileira NBR9781 (1987).

A NBR 9781/87 define como peça de concreto para pavimentação: bloco prémoldado, de formato geométrico regular, com comprimento máximo de $400 \mathrm{~mm}$. Largura mínima de $100 \mathrm{~mm}$ e altura mínima de $60 \mathrm{~mm}$. 
Também consta em tal norma a definição da resistência à compressão das peças: é a resistência apresentada pela peça em uma determinada idade, quando ensaiada com carregamento parcial de sua área superficial conforme a NBR 9780 (1987).

A NBR 9780/87 também estabelece o método de ensaio para determinação da resistência à compressão das peças pré-moldadas de concreto para pavimentação.

\subsubsection{Equipamento de Ensaio}

O ensaio à compressão deve ser realizado com uma máquina equipada com dois pratos de aço, sendo o superior articulado e a transmissão de carga deve ser feita de forma progressiva sem choques.

Placas circulares de aço com diâmetro de $90 \pm 0,5 \mathrm{~mm}$, denominadas placas auxiliares de ensaio devem ser acopladas à máquina. Uma no prato inferior e outra no superior.

Os eixos verticais centrais de ambas as placas devem estar perfeitamente alinhados. 


\subsubsection{Determinação da Resistência à Compressão (fpj)}

Deve-se saturar as peças a serem ensaiadas em água e com as superfícies de carregamento capeadas com argamassa de enxofre ou similar, com espessura inferior a 3,0mm. A peça deve ser colocada sobre as placas de ensaio e o carregamento realizado continuamente com velocidade de aplicação entre $300 \mathrm{kPa} / \mathrm{s}$ e $800 \mathrm{kPa} / \mathrm{s}$ até a ruptura completa.

A resistência à compressão (MPa) é determinada através da divisão da carga de ruptura $(\mathrm{N})$ pela área de carregamento $\left(\mathrm{mm}^{2}\right)$, o resultado deve ser multiplicado pelo fator "P" da Tabela 3 a seguir em função da altura da peça.

\section{Altura nominal da peça (mm)}

60

80

100

\section{Fator "P"}

0,95

1,00

1,05

Tabela 3 - Fator "P” (NBR9780/1987) 


\subsubsection{Valor Característico da Resistência à Compressão (fpk)}

A resistência à compressão obedece a uma distribuição estatística normal (NBR9781/1987), por tanto o valor da resistência característica pode ser calculada pela equação:

$f_{p k}=f_{p}-t^{*} s$

Sendo:

$f_{p k}$ - Resistência característica à compressão (MPa);

$f_{p}$ - Resistência média das peças ensaiadas (MPa);

$s$ - Desvio Padrão da amostra (MPa);

$t$ - Coeficiente de Student, em função do tamanho da amostra.

A resistência característica à compressão, estimada, dos blocos de concreto convencionais deve ser igual ou superior a $35 \mathrm{MPa}$ levando em consideração as solicitações de veículos comerciais de linha. Deve ser igual ou superior a $50 \mathrm{MPa}$, quando houver veículos especiais ou solicitações capazes de produzir acentuados efeitos de abrasão.

A norma NBR 9781/87 citada anteriormente também estipula valores para a máxima variação permissível das peças sendo estas de $3,0 \mathrm{~mm}$ no comprimento ou largura e $5,0 \mathrm{~mm}$ na altura.

\subsubsection{Influências na Resistência do Concreto}

A resistência à compressão do concreto sofre influência de alguns fatores tais quais o fator água cimento e a idade do concreto (Almeida, 2002). 


\subsubsection{Fator Água-Cimento $(\mathrm{a} / \mathrm{c})$}

No Gráfico 3 a seguir, está representada a lei que relaciona resistência do concreto ao fator água cimento.

A resistência tende a aumentar com o aumento do fator $\mathrm{a} / \mathrm{c}$ até um determinado valor limite. Daí em diante, a resistência reduz com o aumento desse mesmo fator.

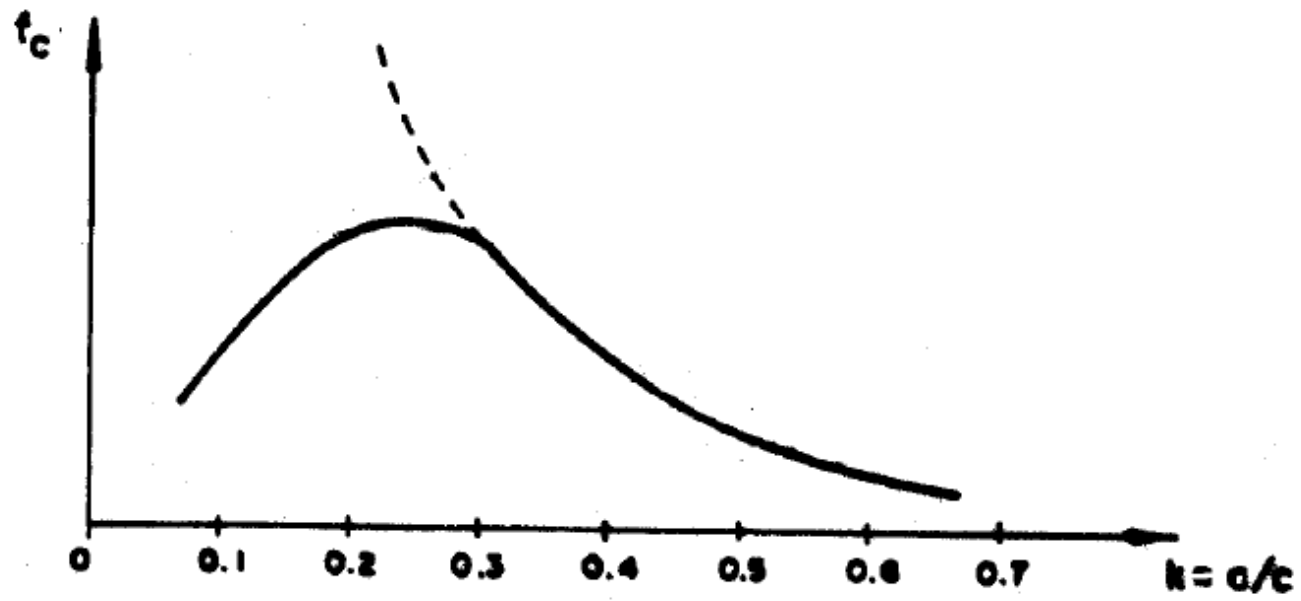

Gráfico 3 - Resistência do concreto em função do fator a/c

\subsubsection{Influência da Idade do Concreto}

A resistência do concreto tende a aumentar conforme sua idade. O Gráfico 4 a seguir representa tal comportamento.

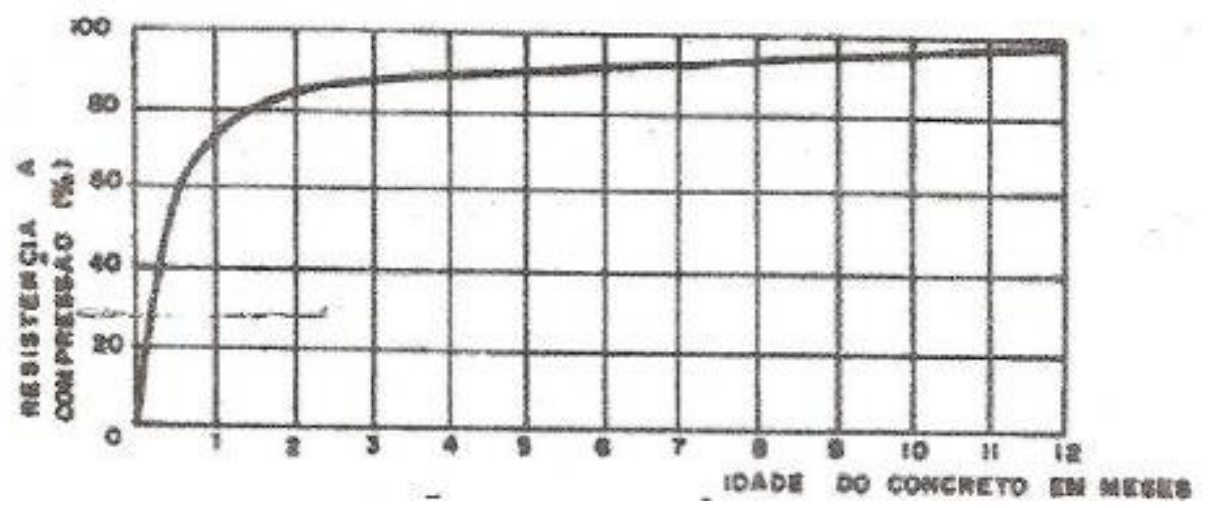

Gráfico 4 - Resistência do concreto em função da idade 


\subsubsection{Pavimento Permeável em Blocos de Concreto}

Estruturas com superfície em blocos de concreto poroso ou vazado possibilitam a infiltração das águas superficiais. Essas estruturas são constituídas de parte inferior e superior conforme se mostra a seguir (Figura 19).

A parte inferior é composta pelo subleito e a camada de base em brita graduada. A parte superior apresenta uma camada de instalação composta de areia grossa e a superfície em blocos porosos ou vazados que são rejuntados com o mesmo material utilizado na camada de instalação.

Nessa estrutura, o conjunto de camadas deve dispor de uma capacidade de drenagem compatível com a do subleito. Para que esta condição seja respeitada, a quantidade de partes finas deve ser reduzida, porém, é necessário evitar que os agregados de diferentes camadas venham a se misturar. Pode-se optar pela utilização de mantas de geotêxtil, evitando assim que os solos percam capacidade de infiltração (Febestral, 2005).
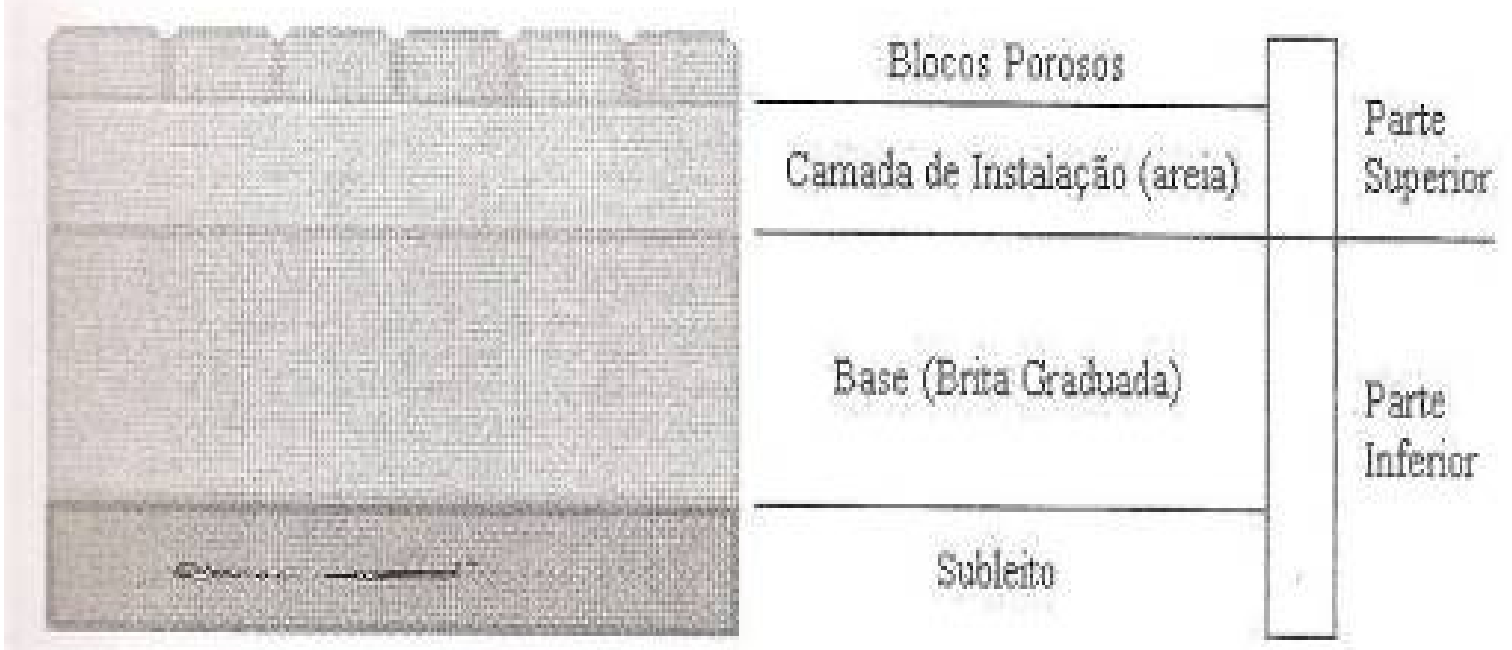

Figura 19 - Pavimento permeável com superfície de blocos porosos ou vazados (Febestral, 2005). 


\subsubsection{Tipos de Blocos para Estruturas Permeáveis}

Tendo em vista as vantagens proporcionadas pelo uso do pavimento permeável em blocos de concreto, empresas belgas fabricantes de blocos de concreto passaram a fabricar três tipos diferentes de blocos que possibilitam a drenagem das águas superficiais:

- Bloco de concreto poroso - Este tipo possui estrutura aberta o que o torna permeável em todo o seu volume. Essa estrutura aberta é permitida graças a uma composição específica do concreto;

- Bloco de concreto com juntas alargadas - Trata-se de blocos de utilização comum em pavimentação, no entanto, possuem afastadores que permitem a criação de junta mais larga no momento da execução. Tais juntas permitem que a água escoe mais rapidamente;

- Bloco de concreto com aberturas de drenagem - Trata-se de blocos de concreto com aberturas em forma de meia-lua que permitem a infiltração da água existente na superfície.

A escolha do tipo de bloco depende principalmente do lugar de aplicação.

Para que seja válida a utilização de blocos permeáveis, as diferentes camadas da estrutura devem dispor igualmente de capacidade de drenagem que seja compatível com a permeabilidade do subleito. (Febestral. 2005). 


\subsubsection{Princípio de Funcionamento}

O funcionamento das estruturas de pavimentos permeáveis está fundado em três elementos. As águas de chuvas são estocadas nos vazios dos blocos permeáveis e nos vazios da estrutura do pavimento que posteriormente se infiltram no solo do subleito em função de seu grau de permeabilidade e quantidade de água que não se infiltra é drenada por sistemas tradicionais de escoamento (Febestral, 2005).

\subsubsection{Domínio de Aplicação}

A utilização de pavimentos permeáveis não pode colocar em perigo a estabilidade e a durabilidade do pavimento. Deve-se limitar o seu campo de aplicação tendo em vista o tráfego o qual o mesmo irá suportar.

Esse tipo de pavimento deve, portanto, ser utilizado em locais de tráfego leve, muito leve e em locais onde não existe tráfego de veículos pesados (Febestral. 2005).

Podem-se citar estacionamentos, pátios industriais, ruas residenciais, praças, ruas para pedestres, ciclovias, terraços, centros comerciais, entre outros, como locais para aplicação dos pavimentos permeáveis. 


\subsection{Estudo do Concreto Asfáltico Poroso}

\subsubsection{Histórico}

O concreto asfáltico poroso foi usado a partir da metade do século passado em estradas de rodagem como sobrecamada do revestimento asfáltico cuja finalidade era a de proporcionar melhor drenagem superficial e segurança.

Conforme Baptista \& Nascimento (2005), a utilização da técnica de concretos asfálticos porosos é relativamente recente, tendo em vista que a concepção tradicional de pavimentos preconizava sua impermeabilização. A partir do final dos anos 1970, na Europa e na América do Norte, a combinação dos aspectos de segurança na circulação viária e a possibilidade de respostas aos problemas hidrológicos acarretados pelo intenso desenvolvimento urbano, ensejaram estudos experimentais, levando, a partir dos anos 1980 a sua utilização operacional.

Inicialmente o emprego desse tipo de pavimento permaneceu restrito a áreas de estacionamentos, vias de pedestres e vias locais de pequeno tráfego. Com base nos estudos satisfatórios obtidos, atualmente seu emprego é cada vez mais difundido, sendo utilizado mesmo em vias de tráfego significativo como, por exemplo, nas vias de contorno da cidade de Bordeaux, na França. 


\subsubsection{Características do Concreto Asfáltico Poroso}

Neste trabalho optou-se pelo concreto asfáltico tipo CPA, em vista da experiência nacional adquirida sobre o mesmo.

A norma DNER 386/99 define Camada Porosa de Atrito (CPA) como mistura asfáltica porosa (entre 18 e $25 \%$ vazios) preparada em usina a quente, composta de agregados, material de enchimento (fíler) e cimento asfáltico de petróleo modificado ou não por polímero SBS (estileno-butadieno-estileno), espalhado e comprimido a quente.

Recentes pesquisas levaram ao desenvolvimento de concreto asfáltico drenante, que tem granulometria intencionalmente modificada para obtenção de elevadas porosidades total e efetiva (aproximadamente 30\% e 25\%, respectivamente) e por conseqüência alta permeabilidade (Meurer Filho, 2001).

Como vantagens de se empregar uma CPA podem ser citadas:

- Minimização do fenômeno da hidroplanagem - a mistura drenante elimina a água da superfície do pavimento, por conseqüência minimizando o fenômeno da hidroplanagem (CASTRO, 2005).

- Maior resistência à derrapagem com pavimento molhado - a mistura drenante possui alta macrotextura. Esta macrotextura faz com que o pavimento mantenha elevada aderência pneu-pavimento a alta velocidade (Castro, 2005).

- Redução de "spray" de água - a água infiltra no interior da camada drenante eliminando o efeito de "spray" (borrifamento) pela passagem das rodas em movimento (Castro, 2005). 
- Menor reflexão das luzes dos veículos - ao eliminar a película superficial de água reduz-se o fenômeno da reflexão de luzes proporcionando melhor visibilidade e segurança (Castro, 2005).

- Redução do ruído do tráfego - a capacidade de reduzir o nível de ruído da interação pneumático-revestimento das misturas tipo CPA está relacionada, entre outras, pela percentagem de vazios, pela distribuição granulométrica, pela disposição dos agregados em sua superfície e pelas características dos agregados (diâmetro máximo, angulosidade, índice de forma, desgaste, porosidade, etc.).

- Condutividade hidráulica - A capacidade de permitir a passagem de água para as camadas inferiores do pavimento de forma rápida dependendo dos vazios existentes entre agregados.

- Recarga de aqüíferos (desde que possível) - Com as camadas de base e sub base preenchidas de água, pode-se permitir que, através da infiltração a água alcance o lençol freático contribuindo para manter o volume e o nível das águas sub superficiais.

- Formação de reservatórios - se houver impermeabilização entre a subbase e o subleito haverá reserva de água dentro da estrutura do pavimento entre os agregados constituintes das camadas de suporte. Permite-se a detenção temporária e logo após, dispositivos de saída farão com que a água armazenada escoe através de exudório atingindo o sistema de drenagem urbana.

Entretanto, por apresentar elevada porosidade, as misturas asfálticas drenantes possuem algumas limitações:

- Colmatação - a colmatação é tanto mais lenta quanto maior o teor de vazios. Para se conseguir boa drenagem é preciso que a mistura mantenha um mínimo de $20 \%$ de vazios (Castro, 2005). 
- Durabilidade - maior teor de vazios favorece a oxidação e o envelhecimento por ação dos agentes atmosféricos. $O$ alto teor de vazio pode favorecer o dano por ação da água, como o desprendimento de agregado no caso de má adesividade entre o agregado e o ligante. $O$ processo de deterioração é combatido principalmente por aumento da espessura da película de ligante recobrindo os agregados pelo uso de asfalto modificado por polímero (Castro, 2005).

- Custo - pela presença de asfalto modificado por polímero, a necessidade de agregado de qualidade superior, o maior gasto com a sinalização horizontal, e necessidade de camada de ligação de boa qualidade, que podem chegar a dobrar o custo do revestimento drenante em relação a um revestimento convencional (Campos, 1998).

\subsubsection{Uso de Ligantes Modificados por Polímeros}

Em grande parte do território dos Estados Unidos ainda persiste o uso de ligantes convencionais para misturas porosas.

Na Europa, por sua vez, é comum a utilização de ligantes modificados por polímeros e, às vezes, por pó de borracha de pneu e fibras.

O uso de ligantes especiais é justificado, por conferirem maior resistência à oxidação (as misturas porosas pelo seu alto índice de vazios estão muito mais sujeitas a esse tipo de fenômeno). Também proporcionam pontes de ligação mais fortes entre as partículas de agregado (Gonçalves et al, 2000).

Com o uso de ligante convencional, há maior probabilidade de ocorrer propagação de trincas e desagregação, principalmente em locais de ocorrência de esforços tangenciais como em interseções e rampas. 
A película de asfalto modificado por polímero (que envolve os agregados) também é mais flexível e dúctil do que a película de asfalto convencional, promovendo maior coesão entre as partículas de agregados, FHWA 1992.

Ceratti (1997) observou através de ensaios a melhoria das características de resistência à tração e fadiga em misturas densas pela utilização de asfaltos modificados por polímeros.

Guerreiro (1993), a partir da avaliação de trechos experimentais de revestimentos porosos, realizados com ligantes convencionais e com ligantes modificados, observou que os trechos com ligantes modificados por polímeros apresentaram comportamento muito melhor.

Verhaghe (1993) realizou estudos em laboratório, na África do Sul, para comparar misturas porosas com ligantes convencionais e com ligantes modificados por diversos polímeros dentre os quais pode-se citar: SBR (estireno-butadieno borracha), EVA (etileno-acetato de vinila), SBS (estireno-butadieno-estireno).

\subsubsection{Perda no ensaio de Cântabro}

O aspecto crítico de ruína do revestimento poroso é a desagregação com perda de agregados da superfície. O ensaio Cântabro foi utilizado e os resultados são apresentados na Tabela 4. Pode-se observar que a perda de agregados é menor em misturas porosas com ligante modificado por polímeros, particularmente com o SBS.

\begin{tabular}{|l|l|l|l|}
\hline Tipo de ligante & teor de 4\% & teor de 4,5\% & teor de 5\% \\
\hline $60 / 70$ & 14,8 & 9,4 & 7,5 \\
$80 / 100$ & 17,7 & 6,4 & 4,1 \\
controle + 4\% EVA & 11,2 & 10,3 & 7,6 \\
controle + 4\% SBR & 17,3 & 14,7 & 11,4 \\
controle + 4\% SBS & 9,3 & 6,9 & 5,3 \\
\hline
\end{tabular}

Tabela 4 - Perda de agregados no ensaio cântabro (\%) 


\subsubsection{Fadiga}

Foram realizados ensaios à fadiga que indicaram que existe um acréscimo de vida à fadiga pela modificação do ligante por polímeros (Gonçalves et al, 2005). Os resultados desses ensaios são apresentados na Tabela 5 . (10ㅇ, corpos de prova prismáticos).

\begin{tabular}{|l|l|l|l|l|}
\hline Tipo de ligante & $\begin{array}{l}\mathbf{8 0 / 1 0 0} \\
\text { (n.. de Ciclos) }\end{array}$ & $\begin{array}{l}\text { +4\%EVA } \\
\text { (n.o de Ciclos) }\end{array}$ & $\begin{array}{l}\text { +4\%SBR } \\
\text { (n.o de Ciclos) }\end{array}$ & $\begin{array}{l}\mathbf{+ 4 \% S B S} \\
\text { (n.o de Ciclos) }\end{array}$ \\
\hline Mistura 1 vazios 23\% & 31.500 (ciclos) & 29.200 (ciclos) & 117.600 (ciclos) & 111.500 (ciclos) \\
Mistura 2 vazios 17\% & 58.400 (ciclos) & 1.066 .000 (ciclos) & 132.100 (ciclos) & 130.800 (ciclos) \\
\hline
\end{tabular}

Tabela 5 - Vida à fadiga de diversas misturas porosas modificadas por polímeros.

Os valores apresentados de vida à fadiga são expressos como o número de repetições de carregamento (ciclos) para que o módulo do material caia para a metade.

\subsubsection{Envelhecimento e Oxidação}

A avaliação do fator envelhecimento dos ligantes modificados por polímero foi feita por ensaios (Gonçalves et al, 2005), em corpos de prova, com a mesma granulometria e diferentes ligantes (convencional e modificado por vários polímeros), que foram submetidos a condições de intemperismo acelerado e, posteriormente, ensaiados para determinação de vida à fadiga, cujos resultados são apresentados na Tabela 6.

As condições de intemperismo consistam em submeter as amostras a 2 dias, a $60^{\circ} \mathrm{C}$ e a 5 dias, a $107^{\circ} \mathrm{C}$, em estufa.

\begin{tabular}{|l|l|l|}
\hline Tipo de ligante & Mistura Nova (repetições) & Mistura Envelhecida (repetições) \\
\hline $80 / 100$ & 58.400 (ciclos) & 35.500 (ciclos) \\
$+4 \%$ SBR & 132.100 (ciclos) & 115.000 (ciclos) \\
$+4 \%$ SBS & 130.800 (ciclos) & 89.900 (ciclos) \\
\hline
\end{tabular}

Tabela 6 - Valores de vida à fadiga (repetições) para misturas novas e envelhecidas. 
Os polímeros mais utilizados são o SBS e o EVA. Outras modificações de ligantes por polímeros têm sido utilizadas, como a combinação de dois polímeros e uso de pó de borracha de pneus ou BMP (borracha moída de pneus) como é denominada. (Faure 1991).

Como ligantes modificados são mais viscosos, podem-se usar teores maiores que os dos ligantes convencionais, com menor possibilidade de escorrimento do ligante massa, durante o transporte. Em alguns casos, recomenda-se a utilização de fibras para aumentar a coesão da mistura.

A modificação do asfalto por pó de borracha tem se desenvolvido nos últimos anos, com a vantagem de se evitar a poluição ambiental. Dessa forma, o material que seria descartado, pode ser utilizado em uma destinação nobre.

\subsubsection{Considerações Relativas a Custo}

Os revestimentos porosos, normalmente, são mais caros que os revestimentos convencionais. Os motivos principais desse maior custo são:

- As exigências quanto à melhor qualidade dos agregados constituem-se um adicional de custo, pois, muitas vezes, é necessário buscar o material a grandes distâncias do local da aplicação;

- O ligante deve ser modificado por polímero, que é mais caro do que o convencional;

- Há um maior consumo de sinalização horizontal sobre os revestimentos porosos, pois há penetração parcial de tinta;

- Há necessidade de uma camada impermeável subjacente, dependendo do que for concebido; 
- A capacidade estrutural é menor que a do concreto betuminoso convencional, o que resulta, muitas vezes, na utilização de espessuras maiores;

- A conservação do revestimento poroso é normalmente mais cara do que a de concreto betuminoso, pois é necessário que sejam mantidas as características de drenabilidade, durabilidade, etc., na mistura utilizada.

O custo do revestimento poroso varia de país a país; na Alemanha é o dobro das misturas convencionais e, na França, 20\% a mais, Lefebvre (1993).

\subsubsection{Recomendações Construtivas}

Guerreiro (1993) comenta que os processos de construção do revestimento poroso não apresentam diferenças expressivas com relação ao concreto betuminoso convencional, à exceção de algumas particularidades.

Antes da aplicação deste tipo de mistura, há necessidade de uma impermeabilização da superfície existente, para evitar a penetração de água na estrutura do pavimento, seja em implantações ou recuperações, por intermédio de uma imprimação ou tratamento superficial, que deve ser também, preferencialmente, de ligante modificado.

É importante regularizar a superfície a receber o revestimento poroso, de modo que não haja depressões com profundidade maior que $1 \mathrm{~cm}$. Evitam-se, dessa maneira, pequenas bacias que propiciam a acumulação de água entre o revestimento e 0 pavimento existente. Pelo mesmo motivo, a regularização deve propiciar uma declividade transversal adequada ao escoamento da água. Uma recomendação importante a respeito da concepção da seção transversal do pavimento, com esse tipo de revestimento, é prever maneiras e dispositivos que permitam a rápida saída d'água de seu interior. Para essa finalidade podem ser implantados acostamentos permeáveis, drenos subsuperficiais ou, simplesmente, deixar a lateral da camada desobstruída. 
Com relação à compactação, que deve ser a mais intensa possível, não se admite o uso de vibração e rolo de pneus.

As juntas devem ser realizadas de modo a permitir uma continuidade transversal de permeabilidade, evitando interrupções ao fluxo da água através da camada.

\subsection{9. $\quad$ Formulação de Misturas para Revestimentos Porosos}

A formulação de misturas porosas deve levar em conta, como parâmetro principal, o índice de vazios, para se obter as características de drenabilidade e redução de ruídos.

O procedimento de formulação consiste em selecionar o ligante, estabelecer a granulometria dos agregados e o teor de ligante, de modo que o índice de vazios desejado seja atingido e também proporcione estabilidade estrutural.

Para Verhaege (1993), o procedimento para a formulação de uma mistura porosa deve constituir basicamente em:

\section{- Seleção de agregados}

Como a estabilidade da mistura depende fortemente do atrito interno entre as partículas, o agregado deve constituir-se de pedra britada, ter baixa abrasão LA e ser resistente ao polimento.

A faixa granulométrica deve ser tal que resulte em um índice de vazios de, no mínimo, 20\% na mistura final. 


\section{- Teor de ligante}

O teor de ligante deve ser compreendido numa faixa de valores. O seu limite superior deve ser tal que o índice de vazios seja maior que $20 \%$ e, que não ocorra escorrimento de ligante no transporte.

$O$ valor limite inferior para o teor de ligante deve ser o que promova adequada coesão entre partículas de agregado, para resistir às solicitações que tendem a desagregar o revestimento. Esse teor pode ser determinado pelo Ensaio Cantabro e será o que corresponde à perda de $25 \%$ por abrasão.

A partir dos teores máximos e mínimos, assim definidos, escolhe-se o teor ótimo, levando-se em consideração a questão de custo e trabalhabilidade.

Deve-se ter em mente que os teores mais altos, nesta faixa admissível, representam películas mais espessas, o que proporciona maior resistência à oxidação, maior ligação entre agregados, aumentando a durabilidade do revestimento, Verhaghe (1993).

Com relação ao tráfego solicitante, para estradas com volumes de tráfego com mais de 1000 veículos comerciais por dia e por sentido, recomenda-se o uso de ligantes modificados por polímeros, Faure (1991).

\subsubsection{Manutenção do Revestimento Poroso}

A manutenção do revestimento poroso se dá por processos diferentes dos processos de manutenção usuais para revestimentos densos. Deve ser entendida como o conjunto de operações necessárias para que a mistura conserve, ao longo do tempo, suas características próprias de drenabilidade, absorção de ruídos, absorção de deformações e trincamentos.

Essas características são dependentes do índice de vazios do revestimento, de forma que as atividades de manutenção devem ser direcionadas a sua preservação. 
Para GAL (1992), os revestimentos porosos perdem sua permeabilidade devido a diversos fatores e situações de tráfego.

\subsubsection{Colmatação}

A sua intensidade é função de fatores da região, como variedade dos depósitos de material pulverulento e seus tipos. Em zonas urbanas esse problema é bastante acentuado.

O tráfego é outro fator de importância, pois constatou-se que em vias de tráfego intenso o fenômeno é lento e progressivo, pois existe uma sucção provocada pela passagem de veículos, que tende a descolmatar os vazios.

Por outro lado, em locais de tráfego pouco intenso e lento, o "pumping" (bombeamento de partículas para fora da superfície porosa), não acontece de forma expressiva e a colmatação dos vazios é mais rápida.

Essa questão fica evidenciada em uma auto-estrada onde nas faixas de tráfego, os vazios se mantêm por mais tempo do que nos acostamentos.

O mesmo estudo recomenda que o processo de descolmatação deve-se constituir das seguintes operações:

- Limpeza com vassouras a seco ou úmida sem pressão;

- Secagem da parte superior da estrutura;

- Avanço dos equipamentos de manutenção ajustados à situação do revestimento local;

- Regulagem e orientação dos jatos d'água, de acordo com o revestimento;

- Aspiração. 
De acordo com a experiência francesa, essas operações de manutenção da permeabilidade só se fazem sentir após 4 a 5 meses. Isso pode ser explicado pela modificação momentânea do equilíbrio interno de cada camada, que ocasiona uma diminuição inicial das permeabilidades, que aumenta gradativamente, Pariat (1992).

\subsubsection{Degradações e Defeitos Localizados}

No caso de degradações e defeitos bem localizados, como panelas e desestruturação da superfície de áreas menores do que $0,5 \mathrm{~m}^{2}$, a correção pode ser feita com misturas betuminosas convencionais. Apesar das diferenças de características entre as misturas, não há prejuízo ao caráter drenante do revestimento como um todo. (Campos 1998).

\subsubsection{Degradações e Defeitos Extensos}

Para correções de defeitos com mais de algumas dezenas de metros quadrados, deve-se utilizar uma mistura betuminosa com características drenantes similares às do revestimento poroso, para se evitar descontinuidades no percurso d'água no interior da camada, Faure (1988).

\subsubsection{Recuperação no Fim da Vida Útil do Revestimento Poroso}

A manutenção de final de vida útil envolve, normalmente, a superposição de uma camada de reforço sobre a superfície do pavimento existente. Deve-se avaliar o efeito de sobrepor a uma camada aberta, uma camada densa, ou uma camada porosa, ou uma composição das duas.

A experiência internacional é bastante limitada, contudo há trechos já executados de reforços com misturas densas, sem registros de qualquer problema. 
Para pavimentos novos com revestimento poroso, o Catálogo de Estruturas Francês, Setra (1993), recomenda a respeito da manutenção de fim de vida útil, duas possibilidades:

- Fresagem e substituição da camada existente por uma camada drenante nova;

- Superposição de uma nova camada porosa, após impermeabilização da camada antiga, por um tratamento superficial ou processo equivalente.

\subsubsection{Segregação e Faixa Granulométrica}

Os aditivos líquidos de Polímeros fazem o ligante asfáltico menos susceptível ao desagregamento, pois impedem que o ligante flua para o interior da estrutura pétrea tanto na usinagem como em sua aplicação em campo.

A viscosidade da película de ligante asfáltico é da ordem de 4 a 6 vezes maior daqueles utilizados usualmente em misturas convencionais em especial ao CAUQ (Concreto Asfáltico Usinado a Quente) conforme Kuennen, (2003).

Quando comparado aos asfaltos convencionais, a mistura com adição de polímeros é mais rígida em altas temperaturas e mais flexível em baixas temperaturas. A razão é que no interior do ligante o polímero fica protegido da oxidação melhorando o desempenho de ligação entre as partículas de agregado mantendo-as unidas e conferindo maior resistência a deformação e ao desagregamento Hubber, (2000).

As fibras minerais ou celulose conferem o mesmo tipo de estabilidade como os aditivos líquidos de polímeros.

Os polímeros são microscopicamente finos e tem comprimento não maior que $6 \mathrm{~mm}$. Constituem 0,3 a $0,4 \%$ do asfalto em volume. 
Quando misturados, apesar de seu pequeno tamanho, se entrelaçam formando uma rede. Seu travamento dentro da matriz asfáltica pode ser visto na Figura 20.

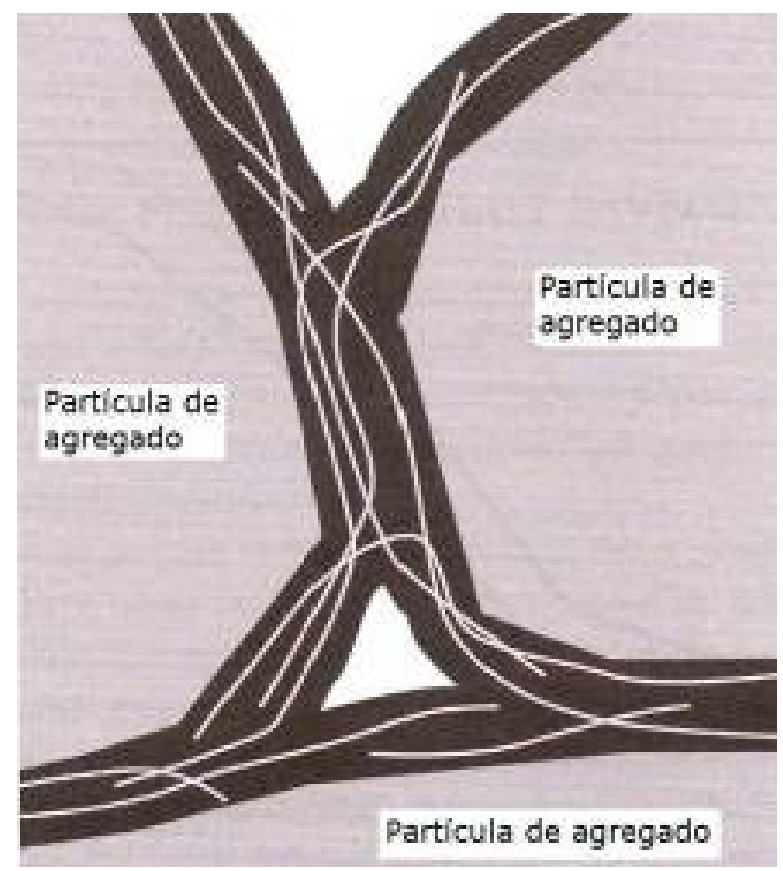

Figura 20 - Conceito de travamento pelas fibras dentro do ligante modificado com polímeros (Fergunson B. K.,2005)

Este travamento impede que o ligante flua para o interior da estrutura, desagregando o material pétreo na superfície. Além disso, permite que maior quantidade de ligante seja incorporado à mistura (30 a 40\%), assegurando que haja total cobrimento dos agregados e protegendo melhor o interior da película dos efeitos da oxidação.

Durante a produção da mistura na usina, tanto as fibras como os polímeros podem ser aquecidos a altas temperaturas. O calor expulsa a umidade natural do agregado, permitindo melhor coesão através do ligante asfáltico reduzindo a segregação do material.

Quando se compara as faixas granulométricas clássicas para CPA's, com novas faixas que permitem que o tamanho máximo do agregado seja maior, chegando as vezes ao dobro do tamanho e a um número muito reduzido de finos, nota-se que as novas faixas (mais abertas) possuem mais vazios uma vez que cada partícula individual de agregado, quando em contato com outra de tamanho semelhante, propicia condições de aumentar o volume individual de vazios (Gráfico 5). 


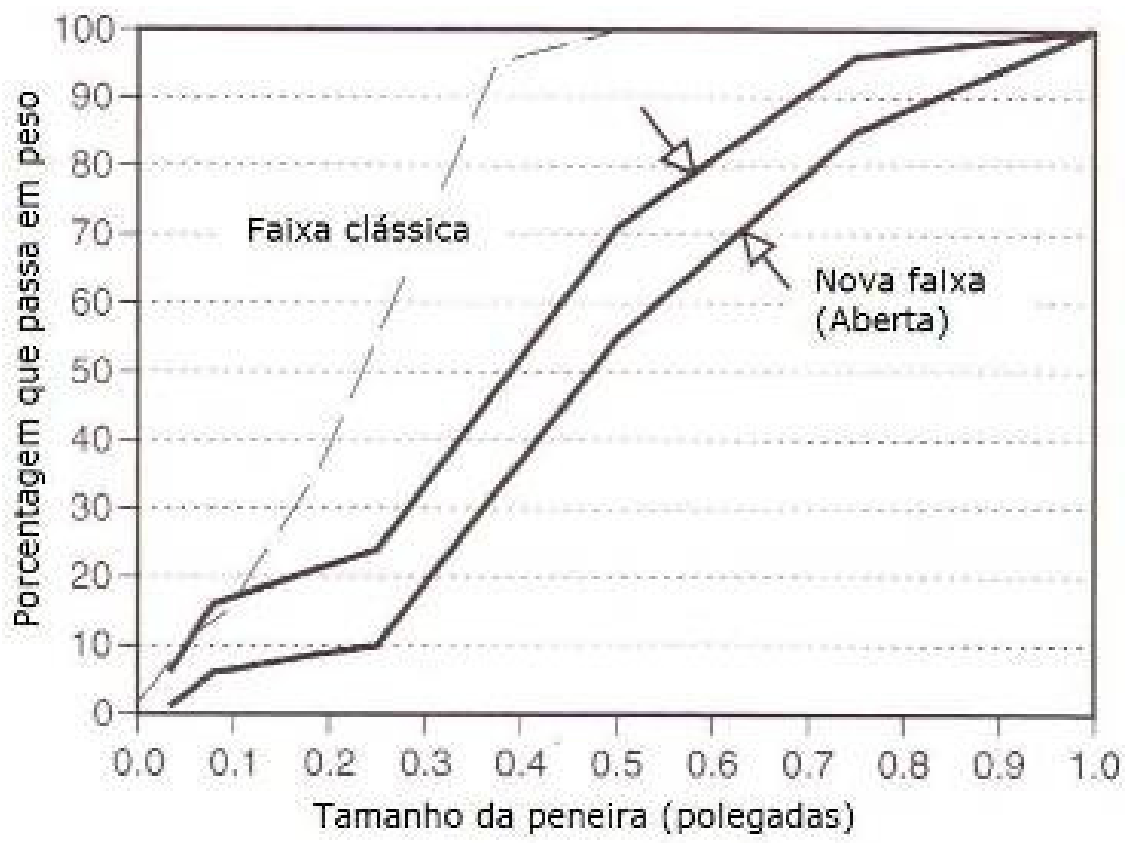

Gráfico 5 - Faixa granulométrica clássica e nova adaptado de Thelen e Howe (1978).

Como conseqüência, o tamanho máximo dos agregados pode aumentar, pois a ligação agregado-agregado fica mais resistente permitindo que haja maior volume de vazios e, portanto aumento na taxa de infiltração.

A tecnologia de utilização de polímeros é responsável pelo aumento da vida útil média da camada estrutural das CPA's. Estas novas mudanças têm aumentado a média de vida dos asfaltos porosos na ordem de 7 a 11 anos quando aplicados como sobrecamada em rodovias (Fergunson B.K, 2005). 


\section{DIRETRIZES DE PROJETO E EXECUÇÃO DO PAVIMENTO PERMEÁVEL}

Sendo muitas as concepções do pavimento permeável, o projeto deverá ser bem elaborado para garantir a sua funcionalidade e eficiência tanto estrutural como hidráulica.

A seguir, apresenta-se fluxograma de desenvolvimento de atividades de projeto mencionando as etapas que devem ser realizadas na prática.

Apresenta-se também o fluxograma de atividades de execução de obras descrevendo as etapas a serem realizadas durante a fase de construção. 


\subsection{Fluxograma das Atividades de Projeto}

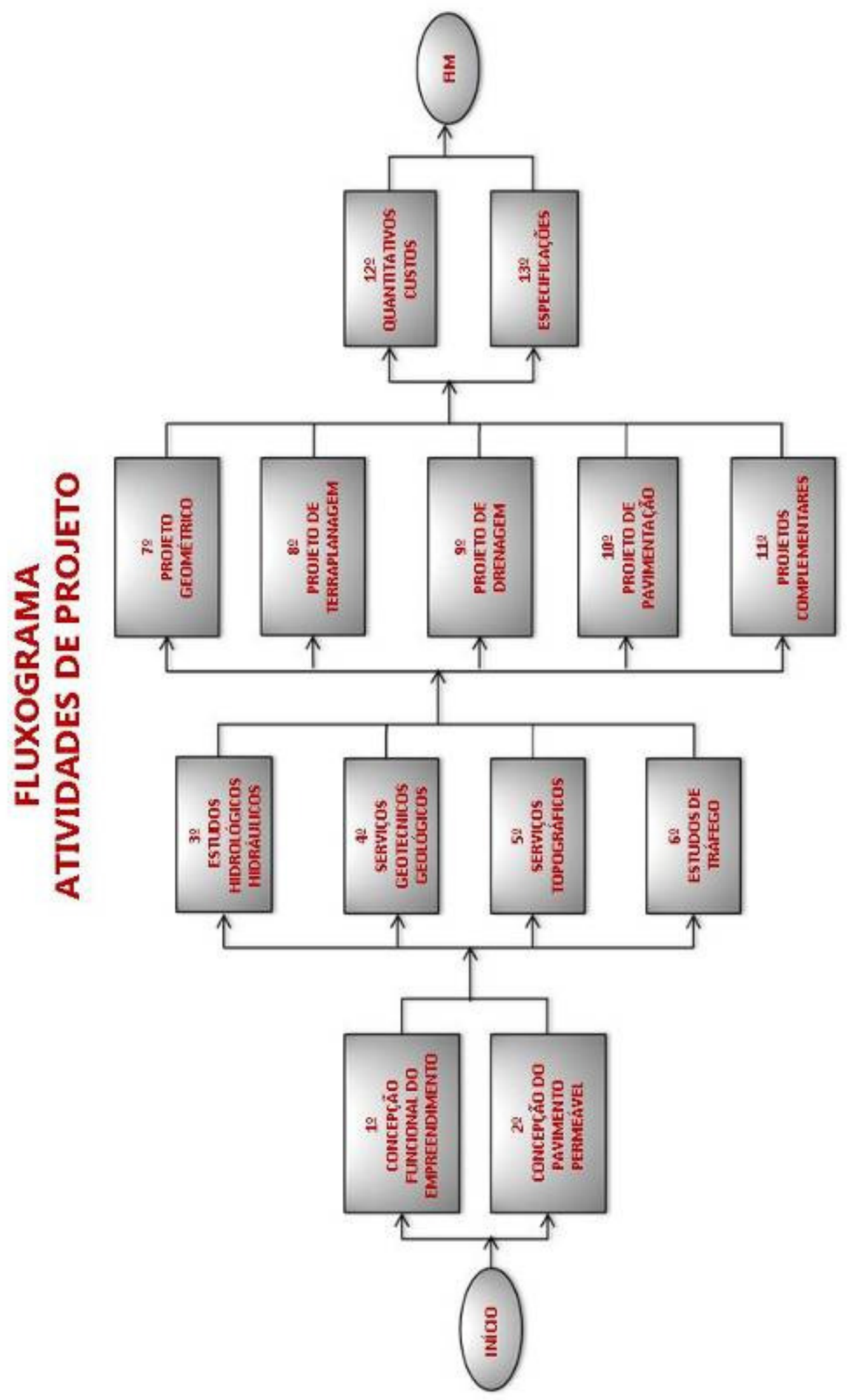

Figura 21 - Fluxograma de atividades de projeto 


\subsection{Atividades de Projeto}

\subsubsection{Concepção Funcional do Empreendimento}

Nesta atividade deverão ser concebidas as características físicas e operacionais da obra onde será executado o pavimento permeável, definindo o seu tipo de uso: estacionamentos, pátio industrial, vias de circulação de condomínios residenciais, parques etc.

É necessário conhecer as vias de acesso, os tipos de usuários, e freqüência de eventos, composição e magnitude dos veículos de carga em relação ao volume total para o devido dimensionamento estrutural do pavimento.

\subsubsection{Concepção do Pavimento Permeável}

Neste item deverão ser definidos o tipo e características de funcionamento de reservatório, bem como do sistema de entrada e saída d'água, procurando seguir o fluxograma mostrado na figura 22 apresentado na seqüência. 


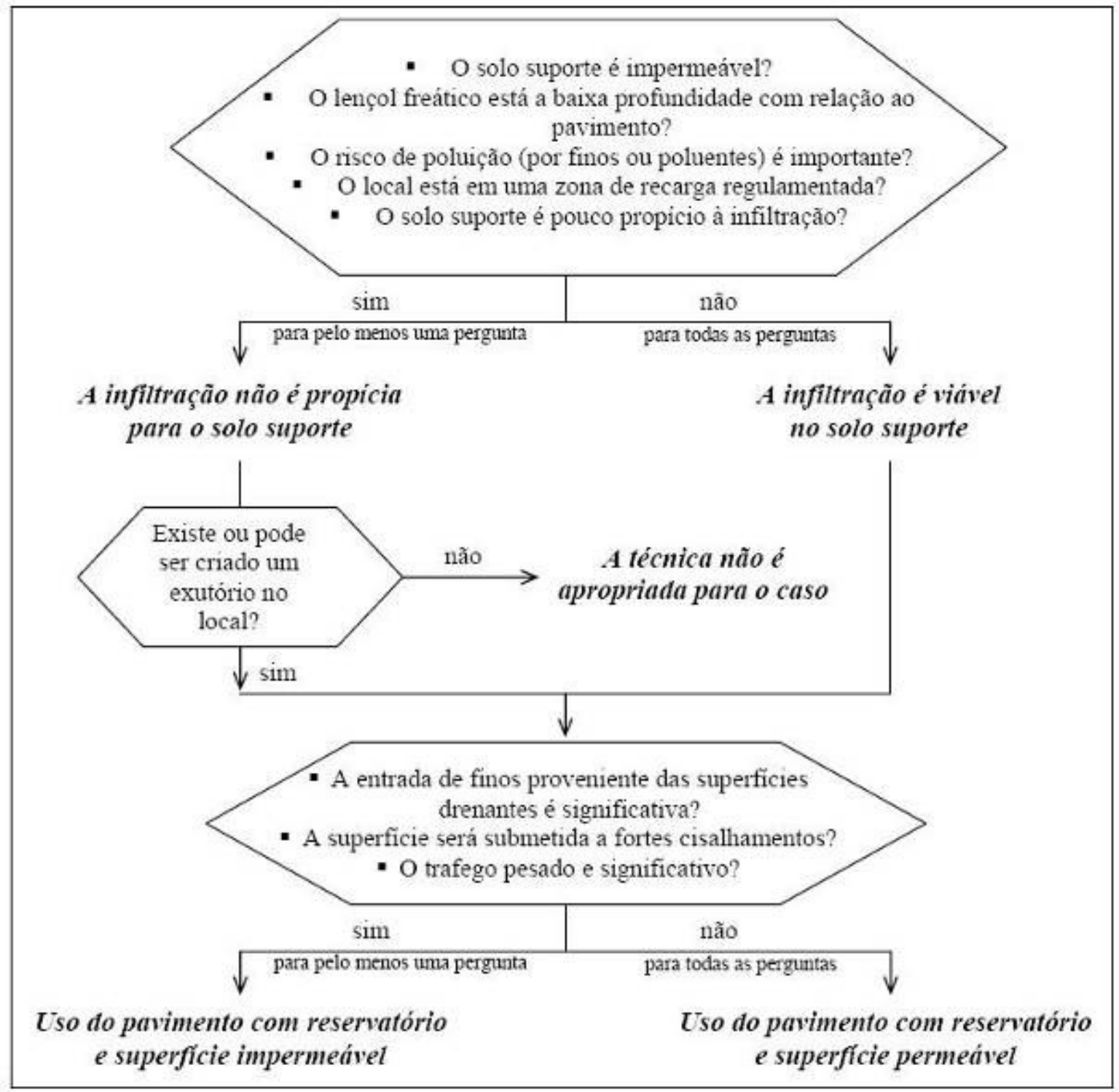

Figura 22 - Fluxograma para análise de viabilidade (L.A. Aciolli, 2005)

\subsubsection{Estudos Hidrológicos e Hidráulicos}

Objetiva-se nesta atividade a estimativa da chuva de projeto considerando as curvas IDF Intensidade/ Duração/ Freqüência para o local do empreendimento.

Os estudos hidrológicos e hidráulicos terão por objetivo a determinação da altura do reservatório para armazenar o volume de água que infiltrará pelo pavimento. Esta altura deverá ser comparada com a obtida no dimensionamento estrutural do pavimento, devendo ser adotada a maior das duas espessuras. 


\subsubsection{Determinação da chuva de projeto}

A chuva de projeto deverá ser definida a partir de equações apropriadas, para a determinação da altura do reservatório.

Cada localidade do Brasil possui diferentes séries históricas de precipitação e, portanto a determinação da intensidade da chuva de projeto deverá ser feita adotando-se a equação que melhor represente a relação IDF (intensidade duração e freqüência). Cada cidade, portanto poderá obter os dados de precipitação através das agências de monitoramento pluviográfico que possuam equipamentos mais próximos ao local de estudo. Podem ser utilizados outros métodos consagrados.

No presente caso, foram adotados os dados de precipitação para a Cidade de São Paulo.

Para a determinação da chuva de projeto recomenda-se a utilização do estudo realizado por Martinez e Magni (1999), que tomou por base a série histórica da Cidade de São Paulo.

\section{- Equação de Martinez-Magni}

Para a cidade de São Paulo a série histórica de máximas intensidades de chuvas anuais observadas e consideradas por Martinez-Magni corresponde a 65 anos de dados (1933 a 1997) do posto pertencente ao IAG (Instituto Astronômico e Geofísico) localizado no Parque do Estado na zona sul de São Paulo.

A média e o desvio padrão para a série histórica é mostrada na Tabela 7 a seguir.

\begin{tabular}{|c|c|c|c|c|c|c|c|c|c|c|}
\hline & \multicolumn{10}{|c|}{ Duração em minutos } \\
\cline { 2 - 12 } & $\mathbf{1 0}$ & $\mathbf{2 0}$ & $\mathbf{3 0}$ & $\mathbf{6 0}$ & $\mathbf{1 2 0}$ & $\mathbf{1 8 0}$ & $\mathbf{3 6 0}$ & $\mathbf{7 2 0}$ & $\mathbf{1 0 8 0}$ & $\mathbf{1 4 4 0}$ \\
\hline Média & 1,655 & 1,322 & 1,079 & 0,713 & 0,409 & 0,291 & 0,161 & 0,087 & 0,061 & 0,048 \\
\hline Desvio & 0,513 & 0,397 & 0,336 & 0,239 & 0,135 & 0,091 & 0,052 & 0,029 & 0,023 & 0,019 \\
\hline
\end{tabular}

Tabela 7 - Média e desvio padrão de máximas intensidades de chuva em $\mathrm{mm} / \mathrm{min}$ 
Foi considerada a seguinte equação definida por Martinez e Magni (1999), para a cidade de São Paulo:

$i_{t, T}=39,30147(t+20)^{-0,92281}+10,17667(t+20)^{-0,87641}\{-0,46532-0,84067 \ln [\ln (T / T-1)]\}$

Sendo:

$\mathbf{i}_{\mathbf{t}, \mathbf{T}}=$ intensidade da chuva, correspondente à duração t e período de retorno $\mathrm{T}$, em $\mathrm{mm} / \mathrm{min}$;

$\mathbf{t}=$ duração da chuva em minutos;

$\mathbf{T}=$ período de retorno em anos.

Ou, em termos de alturas totais precipitadas, a formulação resulta em:

$h_{i, t}=2358,09(t+10)^{-0,92281}+610,6002(t+20)^{-0,8764}\{-27,9192-56,4402 \ln [\ln (T / T-1)]\}$

Sendo:

$\mathbf{h}_{\mathrm{i}, \mathrm{t}}=$ altura total precipitada, correspondente à duração t e o período de retorno $\mathrm{T}$, em $\mathrm{mm}$.

Aplicando-se a equação (2) para alguns períodos de retorno e durações típicas, obtemos os valores previstos de máximas alturas de precipitações, apresentados na Tabela 8, em mm.

\begin{tabular}{|c|c|c|c|c|c|c|c|c|c|}
\hline \multirow{2}{*}{$\begin{array}{c}\text { Duração t } \\
\text { (minutos) }\end{array}$} & $\mathbf{2}$ & $\mathbf{5}$ & $\mathbf{1 0}$ & $\mathbf{1 5}$ & $\mathbf{2 0}$ & $\mathbf{2 5}$ & $\mathbf{5 0}$ & $\mathbf{1 0 0}$ & $\mathbf{2 0 0}$ \\
\cline { 2 - 10 } & $\mathbf{2}$ & $\mathbf{1 0}$ & $\mathbf{8}$ \\
\hline $\mathbf{1 0}$ & 16,2 & 21,1 & 24,4 & 26,2 & 27,5 & 28,5 & 31,6 & 34,6 & 37,6 \\
\hline $\mathbf{2 0}$ & 24,9 & 32,5 & 37,6 & 40,4 & 42,4 & 44,0 & 48,7 & 53,4 & 58,1 \\
\hline $\mathbf{3 0}$ & 30,3 & 39,8 & 46,0 & 49,5 & 52,0 & 53,9 & 59,8 & 65,6 & 71,4 \\
\hline $\mathbf{6 0}$ & 39,3 & 51,8 & 60,1 & 64,7 & 68,0 & 70,5 & 78,3 & 86,0 & 93,6 \\
\hline $\mathbf{1 2 0}$ & 46,8 & 62,1 & 72,2 & 78,0 & 82,0 & 85,1 & 94,6 & 104,0 & 113,4 \\
\hline $\mathbf{1 8 0}$ & 50,5 & 67,3 & 78,4 & 84,7 & 89,1 & 92,4 & 102,9 & 113,2 & 123,5 \\
\hline $\mathbf{3 6 0}$ & 55,7 & 74,9 & 87,5 & 94,7 & 99,7 & 103,6 & 115,4 & 127,2 & 139,0 \\
\hline $\mathbf{7 2 0}$ & 60,2 & 81,5 & 95,6 & 103,6 & 109,2 & 113,5 & 126,7 & 139,9 & 153,0 \\
\hline $\mathbf{1 0 8 0}$ & 62,5 & 85,1 & 100,1 & 108,6 & 114,5 & 119,0 & 133,1 & 147,0 & 160,9 \\
\hline $\mathbf{1 4 4 0}$ & 64,1 & 87,7 & 103,3 & 112,1 & 118,2 & 122,9 & 137,6 & 152,1 & 166,5 \\
\hline
\end{tabular}

Tabela 8 - Máximas alturas previstas, em mm. 


\subsubsection{Dimensionamento Hidráulico do Reservatório}

O dimensionamento envolve a determinação da altura do reservatório para acomodar o volume drenado pela superfície ou por outra contribuinte que escoe para a área do pavimento permeável. A precipitação é obtida com base no tempo de retorno escolhido e da duração da chuva para o local como o utilizado no item anterior.

Para o dimensionamento, o reservatório deve ser grande o suficiente para acomodar o volume do escoamento de uma chuva de projeto menos o volume de escoamento que é infiltrado durante a chuva, que no presente estudo é nulo visto que não se permitirá a infiltração para o subleito do pavimento através da aplicação da geomembrana impermeável.

Cedergren (1980), sugere a utilização da precipitação pluviométrica com tempo de concentração t de 1 hora e período de retorno de $T$ entre 1 e 2 anos, para 0 dimensionamento de dispositivos de drenagem subsuperficial.

A profundidade do reservatório de camadas granulares do pavimento permeável é determinada por:

$$
H=\frac{V r}{n}
$$

Onde:

$\boldsymbol{H}$ é a profundidade do reservatório de material granular, $n$ é a porosidade do material.

Vr é a altura total precipitada, correspondente à duração t e o período de retorno $\mathrm{T}$, em $\mathrm{mm}$. 


\subsubsection{Determinação da porosidade $n$}

A porosidade $(n)$ é calculada de acordo com a expressão abaixo:

$$
n=1-\frac{\gamma_{d}}{G_{S} \cdot \gamma_{w}}
$$

Onde:

$\gamma_{\mathrm{d}}=$ densidade seca do material

$\mathbf{G}_{\mathbf{S}}=$ densidade real dos grãos

$\gamma_{\mathrm{w}}=$ densidade da água

\subsubsection{Determinação da porosidade média $\left(n_{m}\right)$ para várias camadas}

$n_{m}=\frac{\left(h_{1} \times n_{1}\right)+\left(h_{2} \times n_{2}\right)+\ldots+\left(h_{n} \times n_{n}\right)}{h_{1}+h_{2}+\ldots+h_{n}}$

Onde:

$\boldsymbol{n}_{\boldsymbol{m}}=$ Porosidade média das camadas;

$\boldsymbol{h}_{\boldsymbol{1}}=$ altura da primeira camada granular $(\mathrm{cm})$;

$\boldsymbol{n}_{\mathbf{1}}=$ porosidade da primeira camada granular;

$\boldsymbol{h}_{2}=$ altura da segunda camada granular $(\mathrm{cm})$;

$\boldsymbol{n}_{\mathbf{2}}=$ porosidade da segunda camada granular, etc. 


\subsubsection{Serviços Geológicos - Geotécnicos}

Prevê-se nesta atividade o estudo da geologia local, a execução de sondagem para caracterização do material do subleito e retirada de amostras para execução de ensaios geotécnicos correntes, entre eles Limites de Atterberg, Granulometria, Compactação, CBR além de Classificação MCT.

Deverá se verificada a posição do nível do lençol freático, ocorrência de solo mole, disponibilidade de caixas de empréstimo, bem como locais para depósito de materiais excedentes.

Deverão ser avaliadas as características de permeabilidade do material existente no subleito para definição do tipo de funcionamento do reservatório (infiltração parcial ou armazenamento total).

Os serviços são importantes para o desenvolvimento da concepção do pavimento e dos projetos geométrico, de terraplenagem e de drenagem. As normas utilizadas foram as seguintes:

- DNER ME 041/94 - Preparação de Amostras para Ensaios de Caracterização

- DNER ME 080/94 - Análise granulométrica por peneiramento e sedimentação

- DNER ME 082/94 - Determinação de Limite de Plasticidade

- DNER ME 122/94 - Determinação do Limite de Liquidez

- DNER ME 129/94 - Compactação Utilizando Amostras não Trabalhadas

- DNER ME 049/94 - Determinação do Índice de Suporte Califórnia Utilizando Amostras não Trabalhadas

- $\quad$ ABNT NBR 9603/86 - "Execução de sondagens a Trado

- ABNT NBR 6502/95 - "Rochas e solos - terminologia"

- $\quad$ ABNT NBR 13441/95 - "Rochas e solos - simbologia 


\subsubsection{Serviços Topográficos}

O levantamento planialtimétrico cadastral deverá constituir-se de plantas com curvas de nível ou plano cotado dependendo das características geomorfológicas do local, amarrado ao sistema de drenagem da região.

Além do levantamento de eventuais interferências aéreas e subterrâneas existentes na área de implantação do reservatório, deverão ser cadastradas todas as espécies vegetais de porte significativo ocorrentes na área de intervenção.

\subsubsection{Estudos de Tráfego}

Prevê-se nesta atividade a estimativa do tipo e composição dos volumes de tráfego previsto para o período de projeto.

Deverão ser identificados os principais fluxos e tipos de circulação dos veículos nas áreas internas e nos acessos, objetivando o dimensionamento estrutural do pavimento.

\subsubsection{Projeto Geométrico}

O projeto geométrico deverá ser desenvolvido a partir da definição dos veículos e elementos de projeto, bem como das características físico-operacionais do empreendimento.

Deverão ser estabelecidas as declividades máximas e mínimas admissíveis, raio de giro dos veículos, dimensões de vagas para estacionamento etc.

O projeto geométrico consistirá da elaboração de planta, perfil e seções transversais em escalas convenientes. 


\subsubsection{Projeto de Terraplenagem}

O projeto de terraplenagem envolverá o cálculo dos volumes de corte e aterro, levando em consideração fatores de empolamento, compactação e tipo de material escavado.

Deverão ser estimados os serviços de limpeza e eventual demolição de dispositivos existentes para cálculo do volume de remoção dos entulhos.

Deverão também ser levantadas as distâncias de transporte de materiais de empréstimo e de bota-fora.

\subsubsection{Projeto de Drenagem}

Nesta atividade deverá ser definida a concepção da microdrenagem superficial resultando na elaboração de planta e perfil mostrando a localização e principais características dos dispositivos hidráulicos (diâmetro, extensão, declividade etc.). 0 detalhamento dos demais dispositivos de drenagem profunda e subsuperficial também se faz necessário.

\subsubsection{Projeto de Pavimentação}

Prevê-se nesta atividade a definição da concepção do pavimento, principalmente do tipo de material para o revestimento, (peças pré-moldadas de concreto de cimento Portland, concreto asfáltico), permeabilidade dos materiais etc.

Para fins de determinação das espessuras correspondentes às camadas de base e sub-base da estrutura dos pavimentos, recomenda-se a utilização das normas da Prefeitura do Município de São Paulo.

- IP-04/2004- dimensionamento de pavimentos flexíveis para tráfego leve e médio. 
- IP-06/2004 - Dimensionamento de pavimentos com blocos intertravados de concreto.

Outras normas e especificações foram usadas como as que seguem:

- ABNT-NBR 9780 - Peças de concreto para pavimentação - determinação da resistência à compressão.

- ABNT-NBR 9781. - Peças de concreto para pavimentação.

- DER/SP ET-DE-P00/028(2006) - Concreto asfáltico poroso com ligante modificado por polímero - camada porosa de atrito.

- DER/SP ET-DE-P00/048(2006) - Pavimento com peças pré-moldadas de concreto.

Para o dimensionamento é necessária a definição dos parâmetros geotécnicos dos materiais disponíveis e selecionados para fins de projeto.

\subsubsection{Projetos Complementares}

Deverão ser desenvolvidos ainda outros projetos, tais como de sinalização, de dispositivos de segurança ou de remanejamento de interferências quando necessário.

Caso haja espécies arbóreas, deverá proceder-se 0 projeto específico para obtenção de licença para remoção ou respectivo transplante antes do início das obras. 


\subsection{Fluxograma das Atividades de Obra}

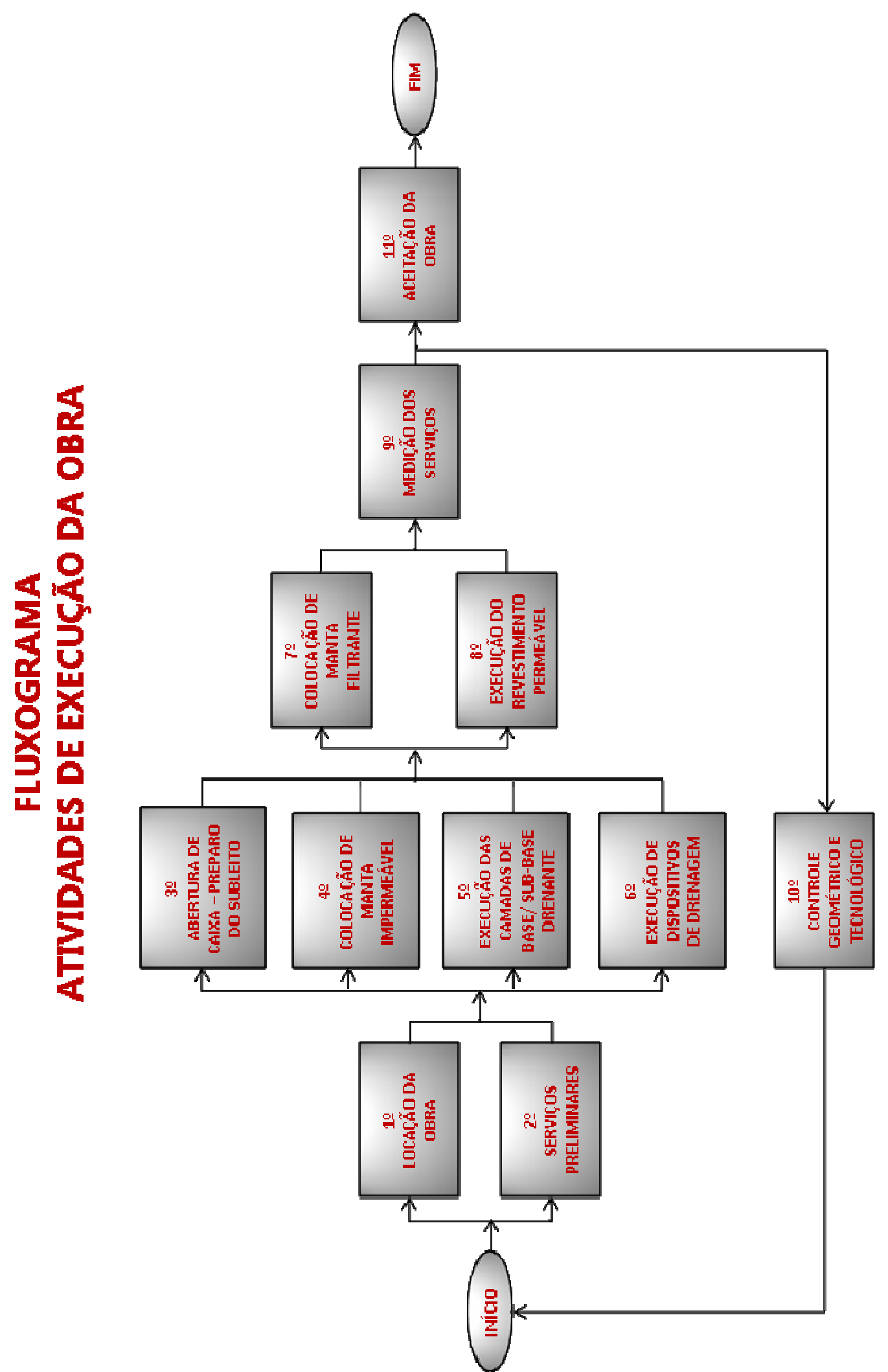

Figura 23 - Fluxograma de atividades de obra 


\subsection{Atividades de Obra}

\subsubsection{Locação da obra}

Com o auxilio da topografia, com o projeto geométrico e o levantamento planialtimétrico cadastral, escolhe-se um ponto de partida com coordenadas conhecidas para a devida locação.

A partir da implantação da poligonal de apoio, deve-se determinar os pontos principais projetados e posicioná-los no local com a indicação da cota e do número da estaca.

Este procedimento deve ser repetido, quadriculando-se a área de 10 em 10 metros, além da marcação de outros pontos relevantes como os limites da obra, eixos transversais e longitudinais, profundidades de corte e aterro, localização do sistema de captação e saída de águas.

Cuidado especial deve ser dado às cotas de inclinação tanto do fundo da caixa do pavimento quanto da superfície acabada.

A topografia deve estar presente em praticamente toda a obra para fornecer pontos de referência aos operadores de equipamentos para espalhamento e compactação das camadas visando sua execução rigorosa em obediência ao projeto.

\subsubsection{Serviços preliminares}

Consiste em proceder a limpeza e remoção de camada vegetal com retroescavadeira ou outro equipamento apropriado cortando a camada de 10 a 15 $\mathrm{cm}$ conforme estiver o terreno. Caso haja superfície concretada efetuar a demolição e transportar o entulho para local de descarte. 
Todo o material deve ser cubicado e lançado em bota-fora apropriado, obrigatoriamente em aterros que possuam documentação e autorização de funcionamento fornecida pelos órgãos públicos competentes.

Um cuidado importante é com os horários permitidos para trânsito de caminhões basculantes trucados ou não em área urbana, além de observar se há excesso na capacidade coroada. Colocar lona protetora impedindo que o material transportado suje as vias por onde passará o veículo.

O peso final dos caminhões e o percurso até o bota-fora devem ser conferidos para não danificar o pavimento das ruas do trajeto deve-se exigir o recibo da área de descarte onde constará a hora, o peso, a cubicagem e o tipo de material lançado.

\subsubsection{Abertura da caixa e preparo do subleito}

O processo de abertura de caixa e preparo do subleito contempla as atividades:

- Proceder a escavação da caixa de pavimentação com escavadeira até a cota predeterminada.

- O projeto de terraplanagem informará o quanto de terra deverá ser reposicionado para compensação de corte e aterro.

- Verificar se há necessidade de importação de terra procurando a jazida mais conveniente.

- Verificar se haverá reforço de subleito abrindo a caixa até a profundidade da troca de material.

- No caso de reforço de subleito, alcançar o valor de CBR para a camada substituída conforme preconiza o projeto de pavimentação.

- Verificar, caso a obra estiver sendo executada dentro do perímetro urbano, a disponibilidade de solo de boa qualidade para reforço dentro das 
proximidades, porém se for o caso, procurar jazidas mais próximas para baratear os custos de transporte.

- Fazer controle tecnológico do solo de reforço através de ensaios de compactação e de CBR no local ou em laboratório.

- Verificar a procedência do material procurando saber se a jazida possui documentação e licenças necessárias obtidas dos órgãos competentes.

- O acabamento final, na cota de projeto deve ser feito com rolo liso ou de pneus obedecendo as declividades impostas no projeto geométrico e de terraplanagem.

- Utilizar as especificações técnicas de materiais e serviços preconizadas pelas normas da PMSP como a PMSP IE-01/2004 - Preparo do subleito do pavimento.

- A compactação deve ser executada dentro dos critérios previstos nas normas e especificações de serviços determinados previamente. 


\subsubsection{Colocação da manta impermeável}

Verificar se o projeto de pavimentos permeáveis foi concebido para fins de infiltração ou armazenamento e detenção. Neste último caso será necessário o assentamento de manta de PEAD (polietileno de alta densidade), conhecida como geomembrana.

Previamente à instalação da geomembrana, é necessário que o subleito seja devidamente nivelado, compactado e isento de qualquer material que possa danificá-la, como materiais cortantes ou pontiagudos.

Recomenda-se que a geomembrana seja instalada logo após o término da preparação do subleito evitando eventuais problemas de deterioração da superfície compactada ocasionados por intempéries, trânsito de veículos ou qualquer fator que cause abaulamentos ou depressões no subleito.

Preparar as ancoragens para fixação da manta por meio de canaletas no contorno do reservatório.

As canaletas de ancoragem devem ser executadas previamente, porém com um mínimo de defasagem da colocação da geomembrana, para evitar a diminuição da sua seção por desbarrancamento dos lados pelo efeito da chuva ou do trânsito local.

As canaletas devem ser escavadas nas dimensões recomendadas no projeto executivo, ou na sua falta, devem estar a uma distância mínima de $60 \mathrm{~cm}$ da borda do talude, e ter no mínimo, largura de $30 \mathrm{~cm}$ e profundidade de $30 \mathrm{~cm}$, valores estes que devem ser função da altura e da inclinação do talude.

A geomembrana deve ser posicionada de forma a ter o mínimo possível de rugas.

As geomembranas devem ser aplicadas por firmas especializadas, pois são vendidas em bobinas de 5,90m por 100,0m sendo que, são soldadas por termofusão no traspasse, que deverá ser de 10 a $15 \mathrm{~cm}$. 


\subsubsection{Execução das camadas de base e sub-base drenante}

Para garantir a integridade da geomembrana, no caso de reservatórios voltados ao armazenamento, deve-se executar uma camada de areia fina de $5 \mathrm{~cm}$ e sobre esta outra camada de $5 \mathrm{~cm}$ de pó-de-pedra. Para reservatórios voltados a infiltração para o solo diretamente, executar manta de geotêxtil sobre o subleito antes de camada de pó-de-pedra.

As primeiras camadas devem ser espalhadas manualmente, pois a tração de pneus poderá romper a manta impermeável.

A partir da camada de pó-de-pedra, proceder ao espalhamento do macadame hidráulico em camadas de $10 \mathrm{~cm}$. Observar que a primeira camada de macadame hidráulico de pedra 3 deve ser lançada com cuidado para não ocorrer a penetração da pedra pelas camadas inferiores atingindo o PEAD.

Utilizaram-se também as especificações técnicas de materiais e serviços preconizadas pelas normas da PMSP como:

- PMSP ES-06/1992 - Sub bases e bases de brita graduada.

Sobre o macadame hidráulico, pode-se executar camada de BGS (brita graduada simples), porém entre estas camadas deve-se executar salgamento com pó-depedra.

As camadas de Macadame hidráulico e BGS podem ser compactadas com rolo liso vibratório de até 1,5 toneladas de peso e com vibração intermediária. 


\subsubsection{Execução dos dispositivos de drenagem}

- Captação do volume de escoamento superficial

Devem-se executar bocas de lobo (BL) localizadas no ponto mais baixo da superfície. Para a correta captação, guias e sarjetas devem ser construídas de maneira a direcionar as águas superficiais para a guia chapéu da boca de lobo.

Atentar para a correta declividade e para a junção entre a guia e a sarjeta não permitindo a infiltração de água pelas juntas.

As bocas de lobo são padronizadas e as caixas devem ser executadas em alvenaria e receber acabamento interno de massa de reboque. A altura das tampas e as cotas de fundo das $B L$ devem respeitar o projeto hidráulico de drenagem.

A saída de tubulação das bocas de lobo para a conexão com o sistema de drenagem deve ser executada com inclinação determinada previamente no projeto. Tomar cuidado para a execução da junção entre a caixa da BL e a tubulação de saída para que seja bem vedada.

Abrir as valas com largura suficiente para o trabalho de assentamento e vedação das bolsas com argamassa.

As tubulações em tubos de concreto tipo ponta e bolsa devem ser assentadas sobre berço de areia e pedrisco sendo as faces laterais preenchidas com areia grossa ou solos compactados manualmente.

Após o assentamento e a compactação, a vala deve ser reaterrada manualmente e compactada com equipamentos pequenos como sapos pneumáticos. 
- Captação do volume do reservatório

Quando o projeto determina que o pavimento permeável atue como sistema de armazenamento devem ser providenciadas saídas para o volume que infiltra e permanece dentro das camadas reservatório.

Sendo este o caso, a captação é realizada por tubos de PEAD furados envolvidos por manta geotêxtil, também assentados na cota mais baixa para colher todo 0 volume que infiltra.

Especial cuidado deve-se tomar com a geomembrana que deve envolver a tubulação na saída, não permitindo fuga de água. Poucos centímetros antes de passar a parede do reservatório o tubo deve ser conectado a tubo comum sem furos que levará a água até uma caixa e dela para o sistema de drenagem.

Atentar para as cotas de fundo das caixas e da tubulação de captação para que não fiquem abaixo do sistema de drenagem existente, pois poderá haver refluxo, inviabilizando o pavimento permeável.

Quando não for concebido reservatório de armazenamento a água será infiltrada pelo solo do subleito de maneira lenta recarregando o aqǘfero de maneira natural desde que o lençol freático encontre-se abaixo do subleito.

\subsubsection{Colocação da manta filtrante}

Visando o bom funcionamento do pavimento permeável construído com PPC (peças pré-moldadas de concreto), no caso de blocos intertravados de concreto, deve-se prever a aplicação de manta geotêxtil de polipropileno não tecido.

Uma vez que as peças são assentadas sobre camada de areia, coloca-se a manta com o propósito de bloquear a passagem de grãos de areia para a camada inferior. 
A manta tem a função filtrante e deve ser assentada em toda a área do pavimento.

Observar a gramatura do geotêxtil em relação a granulometria da areia. A mais recomendada é a de $300 \mathrm{gr} / \mathrm{m}^{2}$, que impede a passagem de partículas do tamanho das de areia.

\subsubsection{Execução do revestimento permeável.}

- Concreto asfáltico poroso tipo CPA

Por ser a parte mais importante do pavimento, verificar que sua produção, transporte e aplicação estejam de acordo com as normas preconizadas através do DER em DER/SP ET-DE-P00/028(2006) - Concreto asfáltico poroso com ligante modificado por polímero - camada porosa de atrito.

Executar sobre camada de macadame betuminoso conforme especificações da Prefeitura do Município de São Paulo, PMSP ES-07/1992 - Camadas de Macadame Betuminoso.

Atentar para o fato de que a camada inferior ao CPA deverá possuir gradação aberta, porém ser suficientemente resistente aos esforços impostos pelo tráfego local além de conferir boa resistência ao cisalhamento.

Não executar imprimadura impermeabilizante do tipo RR (ruptura rápida), pois estes materiais possuem baixo teor de viscosidade na temperatura de aplicação, permitindo assim a sua penetração na camada de base, impermeabilizando-a.

Deve-se fazer o uso de imprimadura ligante executada com ADP, Asfalto Diluído de Petróleo do tipo CM-30 apenas no Macadame Betuminoso e na interface entre ele e o concreto asfáltico tipo CPA com a finalidade de ligação do material pétreo entre si e ligação com a camada superior de revestimento. 
- $\mathrm{PPC}-$ Blocos intertravados de concreto

Assentar os blocos sobre berço de areia. Verificar seu travamento com as guias para não ocorrer o destacamento das peças. Verificar se os blocos atendem as especificações DER/SP ET-DE-P00/048(2006) - Pavimento com peças prémoldadas de concreto.

De acordo com as normas ABNT 9780/87, os blocos convencionais devem ter resistência a ruptura de $35 \mathrm{MPa}$. No entanto as normas referem-se às $\mathrm{PPC}$ - peças pré-moldadas de concreto maciço, utilizadas usualmente em calçadas e passeios públicos ou outras áreas, que não apresentam taxa de infiltração ou permeabilidade da própria peça.

No presente estudo, porém, foram desenvolvidas peças de concreto poroso cuja taxa de infiltração média resultou em $0,5 \mathrm{~cm} / \mathrm{s}$ dentro do admitido pela literatura conforme Haselbach et al, 2006 que estabelece como valores aceitáveis a infiltração do concreto permeável entre $0,2 \mathrm{~cm} / \mathrm{s}$ até $1,0 \mathrm{~cm} / \mathrm{s}$.

Uma vez que os blocos de concreto poroso possuem índice de vazios significativamente maiores que os preconizados pela norma, entende-se que a resistência à compressão dos blocos porosos deva ser bem menor. Os valores de resistência à compressão obtidos pela ABCP (Associação Brasileira de Cimento Portland) para os blocos desenvolvidos para o experimento chegaram a média de 25 $\mathrm{MPa}$ a 28 dias de idade. Assim, conforme estudos da ABCP esse valor pode ser aceito para aplicação em locais com pouca solicitação de tráfego, no caso tráfego leve.

Verificar se a padronização é a mesma para toda a superfície e que as peças não apresentem fissuras ou arestas quebradas. As peças devem ser verificadas quanto a possuírem espaçadores não permitindo o contato face a face, que impede a infiltração. 


\subsubsection{Medição dos serviços}

Conforme contrato por preço unitário ou valor global.

\subsubsection{Controle geométrico e tecnológico}

Todas as etapas executivas serão monitoradas e controladas por firma especializada, contratada diretamente pelo interessado e sem algum vínculo com a empresa executora dos serviços.

Cabe a empresa de controle tecnológico, aceitar, recusar, solicitar a troca ou o refazimento de qualquer material ou serviço.

O controle deve seguir a normatização e especificações vigentes adotadas.

\subsubsection{Aceitação da obra}

Somente após todas as etapas passarem pelo controle geométrico e tecnológico e estiverem de acordo com as normas e especificações de serviços e materiais, a fiscalização poderá emitir o termo de recebimento provisório.

O termo terá a validade de 6 meses para que, antes do recebimento definitivo, se houver necessidade sejam efetuados os reparos por conta da empreiteira. 


\section{ESTUDO DE CASO - ESTACIONAMENTO CTH}

Apresentam-se a seguir de maneira sucinta, alguns aspectos do projeto e detalhes construtivos sobre os dois tipos de pavimentos que serão construídos: um com revestimento em blocos intertravados de concreto e o outro com CPA ou concreto asfáltico poroso.

\subsection{Descrição do Experimento}

Trata-se da pavimentação de área de estacionamento para tráfego leve, localizada dentro das dependências do Centro Tecnológico de Hidráulica (CTH) da Universidade de São Paulo (USP).

A idéia surgiu da necessidade de fornecer à Prefeitura do Município de São Paulo (PMSP) a possibilidade de lançar mão desse tipo de pavimento em muitos empreendimentos por ela desenvolvidos.

Assim a PMSP interessou-se pelo assunto sugerindo estudo mais técnico e aprofundado, visando o estabelecimento de procedimentos de elaboração de projeto e execução de obras para sua utilização em Parques Lineares (Secretaria do Verde e Meio Ambiente), ciclovias, lotes ajardinados, passeios públicos, ruas de tráfego leve em áreas de mananciais, pontos de alagamento por insuficiência de microdrenagem, áreas de estacionamento e calçadas, dentre outros.

A escolha de executar um estacionamento teve por objetivo estudar a metodologia para que grandes empreendimentos que possuam áreas impermeáveis possam fazer uso dessa alternativa em cumprimento a leis do Município de São Paulo que tratam da obrigatoriedade de que os lotes urbanos deixem pelo menos $15 \%$ da área total como área impermeável e "lei das piscininhas" que obriga os empreendimentos reter porcentual de escoamento antes de lançá-lo ao sistema de drenagem. 
Além disso, escolheu-se o tipo de pavimento permeável com a função de reservatório, pois poderá ser utilizado em locais onde existam pontos de alagamento ou lotes que possuam grandes áreas impermeabilizadas, levando-se em conta fatores como a captação e saída além do tipo de tráfego e a capacidade de suporte e capacidade de retenção das camadas granulares.

Após o projeto básico e o orçamento dos serviços foram feitos esforços para a obtenção de recursos para contratação de empresas para execução da topografia, sondagens, ensaios de caracterização, controle tecnológico etc.

A contratação da empreiteira por meio de procedimento licitatório baseado na Lei

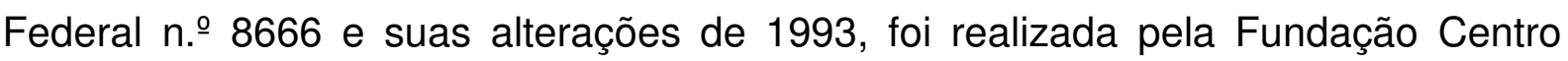
Tecnológico de Hidráulica.

Concomitantemente ao certame licitatório, até mesmo alguns meses antes foram realizados levantamentos das interferências como fios de eletricidade alimentadora do sistema de iluminação da área externa, sistema de captação de águas dos telhados ao redor do experimento, visando garantir que o mesmo não interferisse com as águas pluviais que atingissem o local do experimento.

Foram feitos estudos complementares como de transplante de espécies arbóreas que estavam interferindo no empreendimento e projeto de compensação ambiental de acordo com diretrizes da Secretaria do Verde e Meio Ambiente na sua portaria n. ${ }^{\circ}$ 26/2008.

Os projetos foram elaborados com base no levantamento planialtimétrico cadastral da área anotando-se as principais singularidades existentes. Este foi fundamental para a locação de todos os pontos referenciais e para a precisa localização do projeto geométrico. As coordenadas mostram-se importantes para o projeto de terraplenagem onde se considerou os volumes de corte e aterro, além da posição das seções transversais e longitudinais para a implantação do pavimento.

Especial cuidado foi tomado com o sistema de saída do reservatório e da captação do escoamento superficial visto que os instrumentos de medição foram também 
projetados. Considerou-se a boca de lobo pré-existente da rede de drenagem externa, como coletora das águas pluviais tendo-se preliminarmente levantado suas cotas de fundo para a determinação de seu ponto baixo e a direção da galeria.

Para a captação das águas provenientes do escoamento superficial foram projetadas declividades na superfície do revestimento de $0,5 \%$ no sentido longitudinal e 1,0\% no sentido transversal. As inclinações foram definidas para que as águas pluviais permaneçam maior tempo em contato com a superfície do pavimento permitindo sua infiltração. Esta é a razão pela qual se admitiu no projeto declividades baixas alterando-se o conceito de escoamento rápido para fora da superfície que é normalmente adotado em obras de pavimentação.

Executou-se aproximadamente $1600 \mathrm{~m}^{2}$ de pavimento permeável divididos em 800 $\mathrm{m}^{2}$ de blocos intertravados de concreto (Área B) e $800 \mathrm{~m}^{2}$ de concreto asfáltico poroso (Área C).

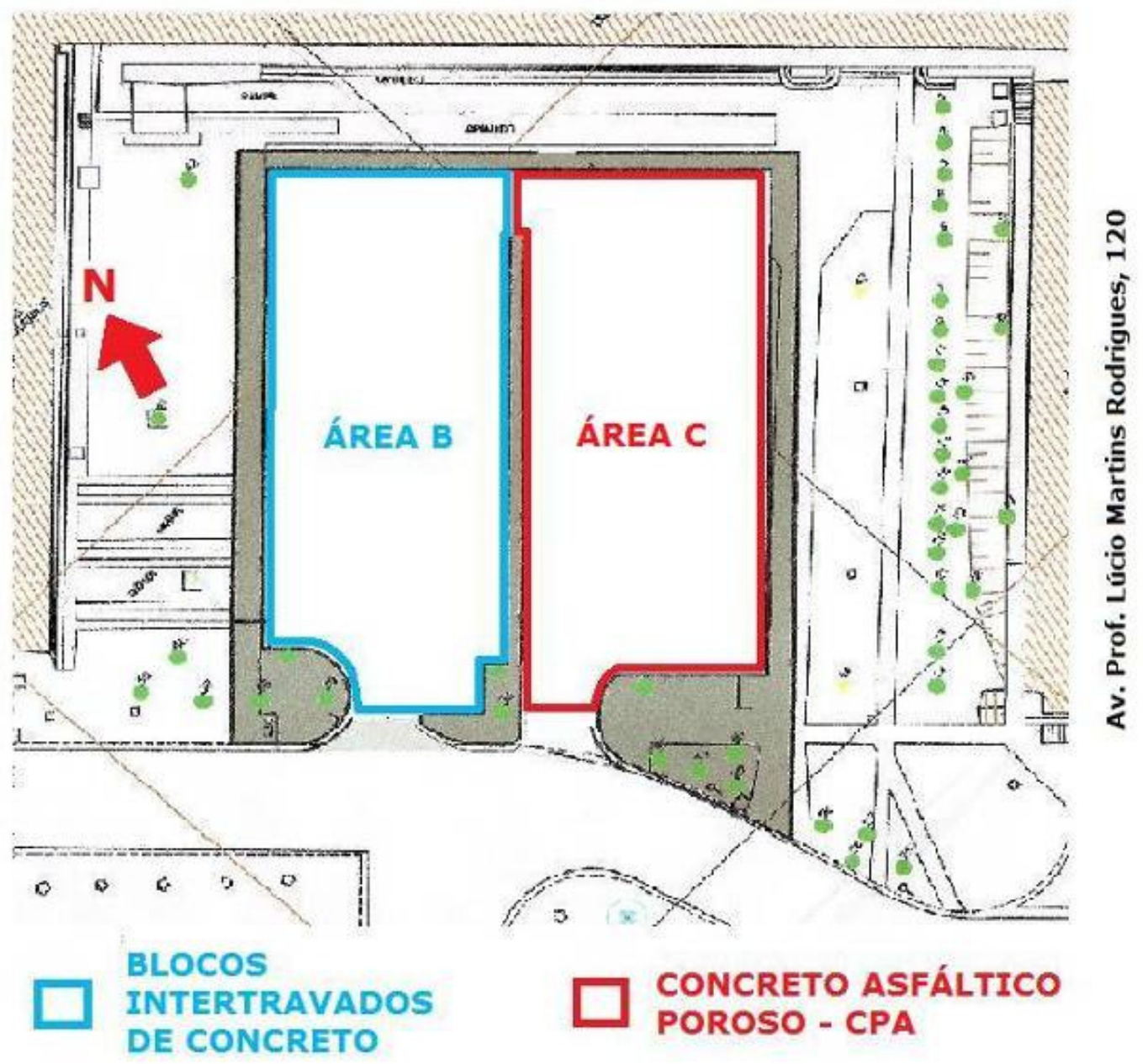

Figura 24 - Vista em planta do local do experimento. 


\subsection{Concepção do Pavimento}

Apresentam-se a seguir, as diretrizes básicas que nortearam a concepção do pavimento permeável para o experimento em questão:

- As estruturas de pavimento selecionadas devem ser dimensionadas de tal forma a suportar os carregamentos impostos pelo tráfego de veículos, predominantemente de passeio, por se tratar de área de estacionamento.

- Os revestimentos devem ser drenantes e as camadas subjacentes de subbase e base constituídas de materiais granulares com teor de vazios que permita reter temporariamente as águas infiltradas.

- Os materiais granulares escolhidos não podem perder resistência significativa quando saturados, para não prejudicar o desempenho estrutural do pavimento.

Os materiais constituintes do reservatório devem apresentar permeabilidade suficiente para permitir a evacuação lenta da água para a rede de drenagem, e apresentar granulometrias apropriadas que evitem problemas de colmatação e de erosão interna em decorrência do fluxo d'água.

\section{AREA B - PPC de Blocos Intertravados de Concreto}

$\mathrm{Na}$ área $\mathrm{B}$ os blocos intertravados de concreto serão assentados sobre berço de areia de aproximadamente $4 \mathrm{~cm}$ e possuirão juntas preenchidas com areia. $\mathrm{O}$ pavimento deverá ser travado em suas extremidades por sarjetas e guias impedindo o destacamento de peças e conseqüente patologia de descontinuidade.

Serão utilizados blocos porosos desenvolvidos para o experimento por empresa associada a $A B C P$, ensaiados quanto a resistência e a taxa de infiltração na própria 
ABCP que alcançaram a resistência média de $25 \mathrm{MPa}$. Serão blocos cuja forma permitirá bom arranjo geométrico sendo possível o desenho de único padrão para toda área designada.

Os blocos são moldados com espaçadores que impedem o contato entre as peças garantindo que areia fina seja utilizada para o preenchimento das juntas.

Separando a camada de areia da base de BGS (Brita Graduada Simples), será colocada manta não-tecida de filamentos de polipropileno (manta geotêxtil), que possibilite a livre passagem das águas de infiltração para o meio drenante. A aplicação desta manta será importante para bloquear o transporte de finos para a camada adjacente que poderia interferir na condutividade hidráulica uma vez que as partículas mais finas tendem a preencher os vazios da base reservatório.

Optou-se por executar camada de $15 \mathrm{~cm}$ de BGS (faixa B do DERSA) sobre Macadame Hidráulico de $15 \mathrm{~cm}$, após salgamento com pó-de-pedra na interface das 2 camadas.

As camadas de BGS e MH estarão assentadas sobre camada de $5 \mathrm{~cm}$ de pó-depedra que tem a finalidade de proteger a geomembrana.

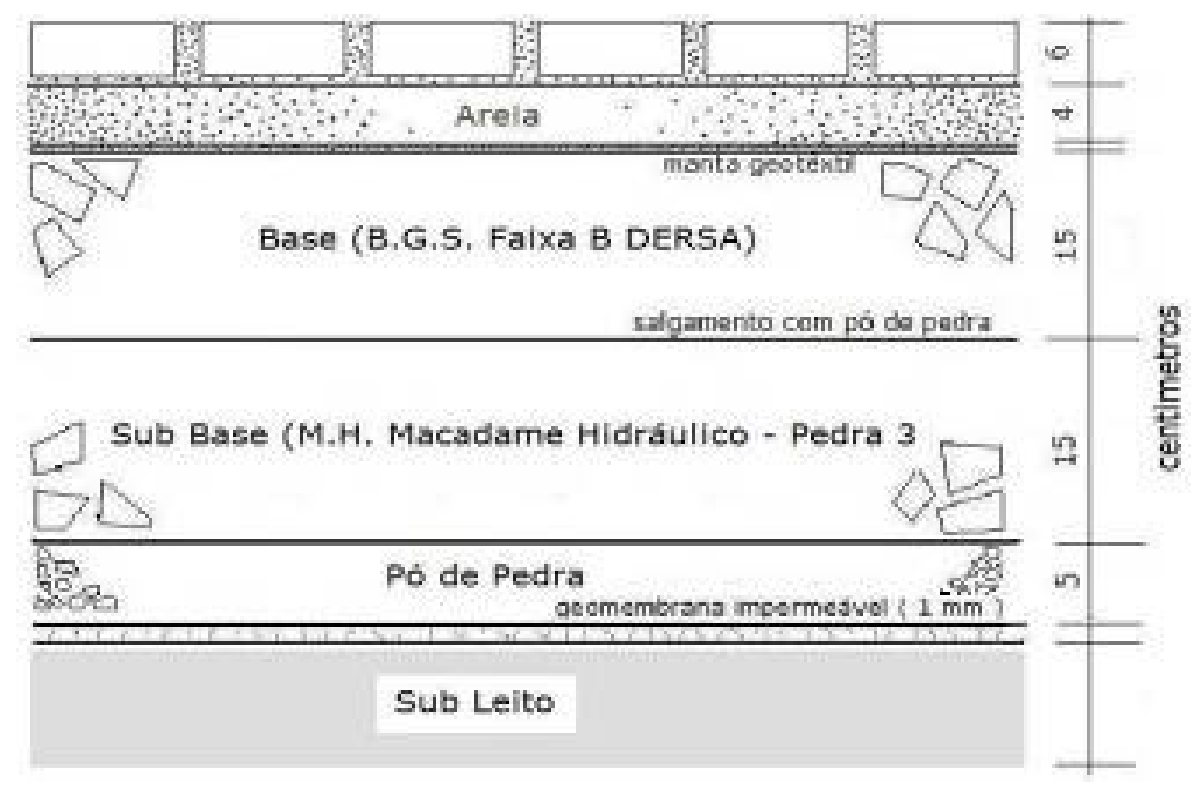

Figura 25 - Perfil do pavimento de Blocos Intertravados (sem escala) 


\section{AREA C - Concreto Asfáltico Poroso}

$\mathrm{Na}$ área $\mathrm{C}$, o concreto asfáltico poroso será tipo CPA (Camada Porosa de Atrito), com agregado uniforme e ligante asfáltico modificado por polímeros com adição de fibras aplicado sobre camada de $5 \mathrm{~cm}$ de macadame betuminoso.

O revestimento em CPA possuirá espessura de $5 \mathrm{~cm}$.

Visando a melhor drenabilidade optou-se por uma única camada de Macadame Hidráulico de pedra ก. .3 , em virtude do seu elevado índice de vazios que possibilitará melhor armazenamento da água.

O macadame hidráulico por sua vez será assentado sobre a camada de pó-de-pedra cuja finalidade é proteger a geomembrana.

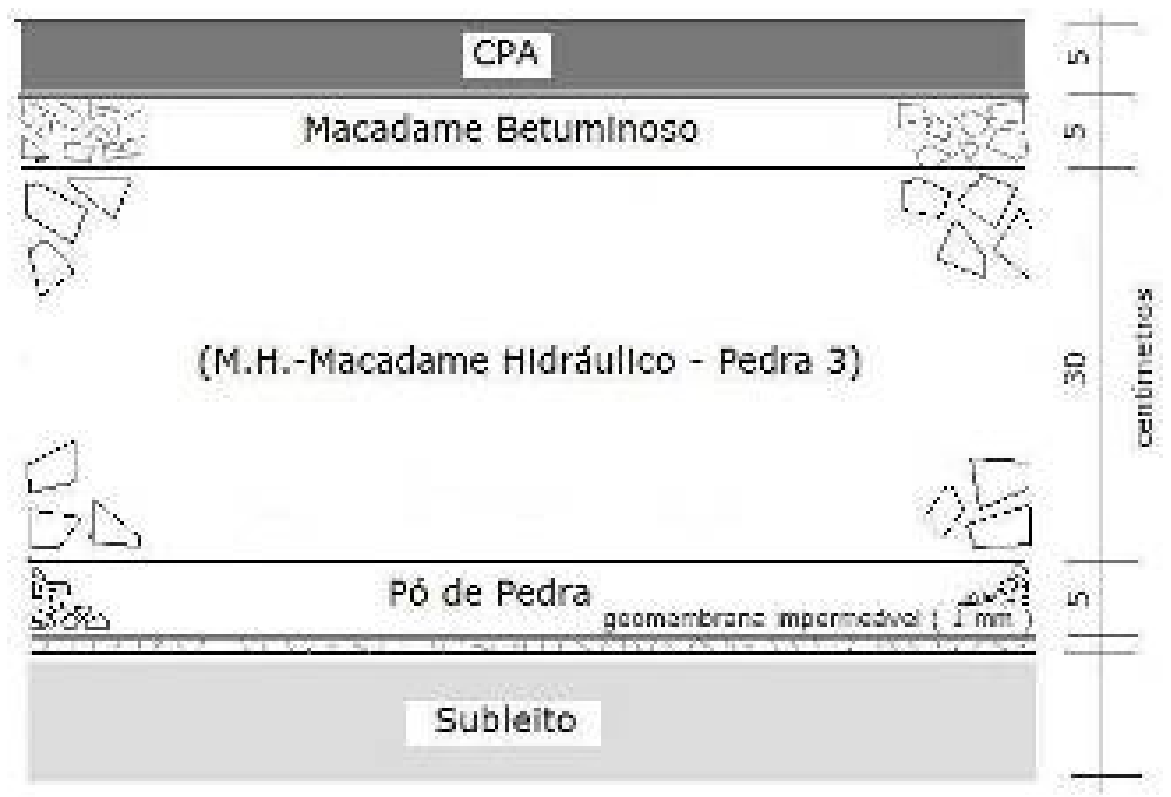

Figura 26 - Perfil do pavimento de CPA (sem escala) 
Todo o pacote granular constituído pela base e sub-base estará assentado sobre geomembrana impermeável de PEAD que terá a função de isolar a estrutura dos pavimentos a serem estudados do subleito ou solo do local do experimento e, também, garantir a integridade do subleito quanto ao seu molhamento como conferir estanqueidade.

Visando o não puncionamento da geomembrana que deverá ser preservada sem furos, optou-se por espalhar uma camada de $5 \mathrm{~cm}$ de pó-de-pedra que atuará como camada protetora impedindo que a pedra 3 do Macadame Hidráulico perfure 0 PEAD.

Para ambos os pavimentos será dado caimento transversal e longitudinal cuja inclinação tanto na superfície quanto na camada de sub-base permitirá o escoamento da água que será monitorado através de sensores piezométricos da quantidade de água infiltrada e de escoamento superficial direto.

\subsection{Estudos Hidrológicos e Hidráulicos}

Para a determinação da altura do reservatório, ou seja, para o cálculo das espessuras das camadas do pavimento quanto aos aspectos hidráulicos, sugere-se a utilização da precipitação pluviométrica com tempo de concentração t de 1 hora e período de retorno de $T$ entre 1 e 2 anos, conforme preconizado por Cedergren para o dimensionamento de dispositivos de drenagem subsuperficial.

Considerando-se a equação proposta por Martinez-Magni para a cidade de São Paulo e admitindo um período de recorrência de 2 anos tem-se: 


\section{$\mathrm{i}=39,3 \mathrm{~mm} / \mathrm{h}$}

Admitindo-se que da intensidade precipitada cerca de 1/3 e 2/3 infiltrará pelo revestimento poroso, tem-se:

\section{$V r=13,1$ a $26,2 \mathrm{~mm} / \mathrm{h}$}

Para a determinação da porosidade $n$ das camadas granulares foram executados ensaios para obtenção dos valores $\gamma_{\mathrm{d}}$ (densidade seca do material), $\mathrm{G}_{\mathrm{S}}$ (densidade real dos grãos) e $\gamma_{w}$ (densidade da água), que foram posteriormente aplicados à fórmula:

$$
n=1-\frac{\gamma_{d}}{G_{S} \cdot \gamma_{w}}
$$

Os valores dos ensaios são apresentados na Tabela 9 - Densidade dos grãos ensaiados e na Tabela 10 - Valores de porosidade $n$ dos materiais das camadas

\section{DENSIDADE DOS GRÃOS}

\begin{tabular}{|c|c|c|}
\hline \multirow{2}{*}{$\begin{array}{c}\text { PARÂMETROS DO } \\
\text { ENSAIO }\end{array}$} & AMOSTRA \\
\cline { 2 - 3 } & Brita graduada simples & Brita 3 \\
\hline Peso seco da amostra $(\mathrm{g})$ & $2.428,3$ & $3.585,0$ \\
\hline Peso úmido(g) & $2.578,3$ & $3.606,51$ \\
\hline Peso imerso $(\mathrm{g})$ & $1.525,0$ & $2.280,71$ \\
\hline Temperatura $\left(^{\circ} \mathrm{C}\right)$ & $25,0^{\circ} \mathrm{C}$ & $25,0^{\circ} \mathrm{C}$ \\
\hline Densidade real dos grãos & 2,643 & 2,704 \\
\hline
\end{tabular}

Tabela 9 - Densidade dos grãos ensaiados. 
POROSIDADE DA CAMADA COMPACTADA

\begin{tabular}{|l|c|c|}
\hline \multicolumn{1}{|c|}{ PARÂMETROS DE CÁLCULO } & \multicolumn{2}{|c|}{ CAMADA } \\
\cline { 2 - 3 } & $\begin{array}{c}\text { Brita } \\
\text { graduada } \\
\text { simples }\end{array}$ & Brita 3 \\
\hline Massa Específica aparente $\left(\mathrm{g} / \mathrm{cm}^{3}\right)-\gamma_{\mathrm{d}}$ & 2,169 & 1,491 \\
\hline Densidade real dos grãos $\left(\mathrm{g} / \mathrm{cm}^{3}\right)-\mathrm{G}_{\mathrm{s}}$ & 2,643 & 2,704 \\
\hline Densidade da água a $25,0^{\circ} \mathrm{C}-\gamma_{\mathrm{w}}$ & 1,000 & 1,000 \\
\hline \multicolumn{1}{|c|}{ Porosidade } & $\mathbf{0 , 1 8}$ & $\mathbf{0 , 4 5}$ \\
\hline
\end{tabular}

Tabela 10 - Valores de porosidade $n$ dos materiais das camadas

O teor de umidade da BGS compactada ficou entre $6,00 \%$ e $7,00 \%$ em peso.

As camadas granulares adotadas no experimento, na situação de menor volume de vazios foi a construída na Área $B$ - Blocos intertravados de concreto permeável, que recebeu $15 \mathrm{~cm}$ de pedra 3 e $10 \mathrm{~cm}$ de BGS.

Tomando-se o perfil do pavimento constituído de $25 \mathrm{~cm}$ de estrutura granular com a finalidade de reservação, dividido em $10 \mathrm{~cm}$ (40\%) de BGS (Brita Graduada Simples faixa B do DERSA) e $15 \mathrm{~cm}$ (60\%) de Macadame Hidráulico Pedra 3, calculamos proporcionalmente a porosidade das duas camadas:

A porosidade média $\left(n_{m}\right)$ é obtida pela fórmula (5)

$n_{m}=\frac{\left(h_{1} \times n_{1}\right)+\left(h_{2} \times n_{2}\right)+\ldots+\left(h_{n} \times n_{n}\right)}{h_{1}+h_{2}+\ldots+h_{n}}$

$n_{m}=\frac{(10 \times 0,18)+(15 \times 0,45)}{10+15}=0,342=34,2 \%$ 
Assim, considerando o armazenamento durante o período de uma hora e que o volume de vazios representa $34,2 \%$ do volume total do material, tem-se que a espessura da camada corresponde à relação entre o volume a ser armazenado e a porosidade média $n_{m}$ que representa o volume de vazios.

$$
\begin{aligned}
& H=\frac{V_{r}}{n_{m}}=\frac{26,2}{0,342}=76,61 \mathrm{~mm} \\
& \rightarrow H=\frac{V_{r}}{n_{m}}=7,66 \mathrm{~cm}
\end{aligned}
$$

Portanto o reservatório deverá ter no mínimo $10 \mathrm{~cm}$ de altura para satisfazer o dimensionamento hidráulico e eventuais problemas de colmatação. 


\subsection{Serviços Geotécnicos e Geológicos}

\subsubsection{Ensaios Correntes}

Dentro desta atividade foram executados sondagens, coleta de amostras e ensaios de laboratório, conforme descrito a seguir:

Foram realizadas três sondagens a trado, com locação definida de acordo com a Figura 27, e com profundidade programada de 1,5 m, para identificação dos tipos de materiais existentes, bem como para verificar a possível existência de nível d'água até a citada profundidade.

No furo de sondagem ST-01 foi coletada uma amostra de solo e no furo de sondagem ST-03 foram coletadas duas amostras de solo, com cerca de $50 \mathrm{~kg}$ para serem submetidas a ensaios de laboratório, segundo procedimento: "DNER PRO 003/94 - Coletas de Amostras Deformadas de Solos".

No furo ST-02 não foram coletadas amostras.

As três amostras coletadas representam os tipos de solos ocorrentes na área do Estacionamento do CTH.

Os resumos dos resultados de ensaios de caracterização, de compactação e de CBR são mostrados na Tabela 11 e Tabela 12 a seguir. 


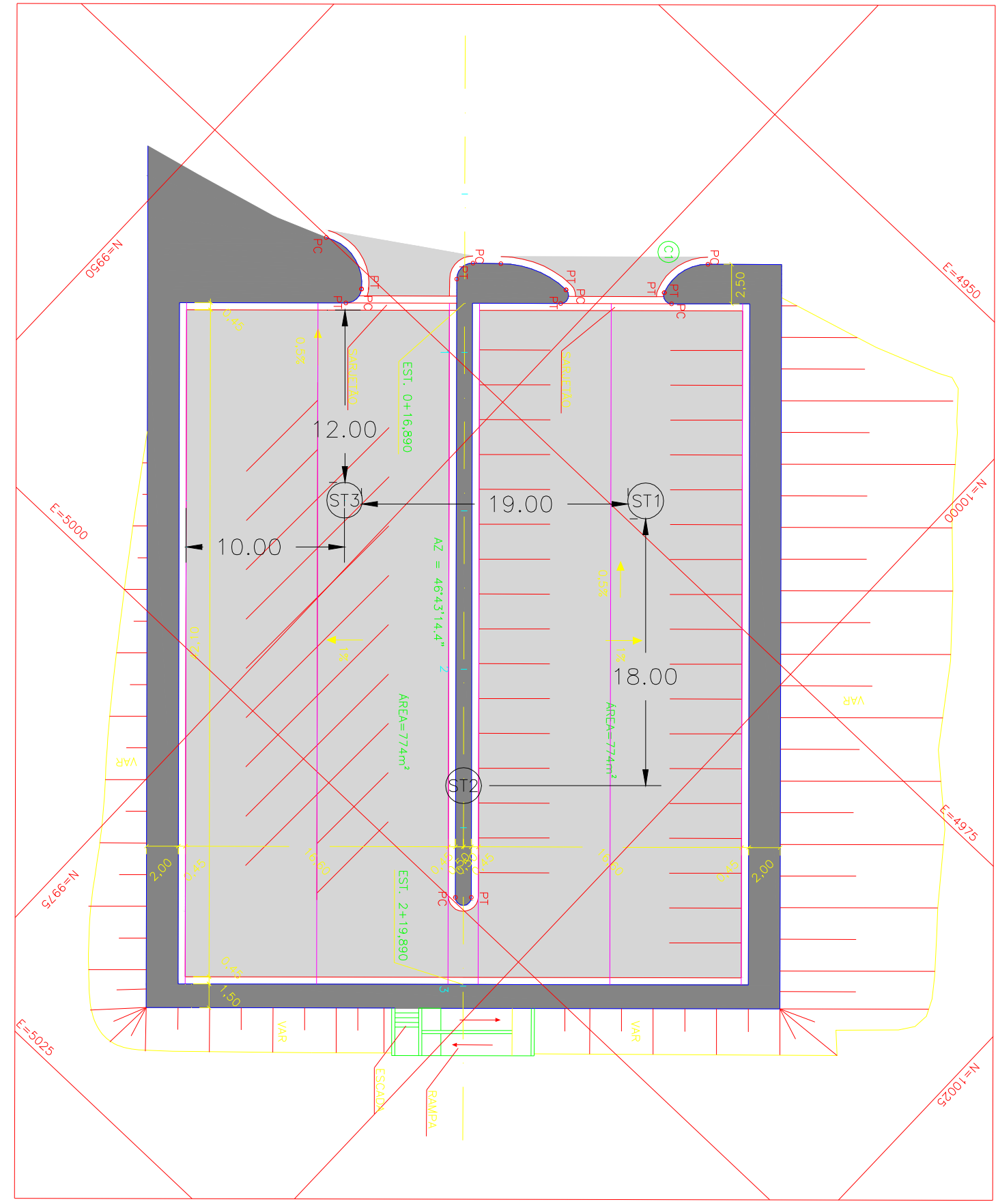

Legenda

(ST) Locais de execução das sondagens a trado

Figura 27 - Localização dos furos das sondagens 


\begin{tabular}{|c|c|c|c|c|c|c|c|c|c|c|}
\hline \multicolumn{11}{|c|}{ Granulometria } \\
\hline $\begin{array}{l}0 \\
\check{\Upsilon} \\
\vec{\nu} \\
\text { L }\end{array}$ & $\begin{array}{l}A \\
M \\
O \\
S \\
T \\
R \\
\text { A }\end{array}$ & $\begin{array}{c}\text { Pedre- } \\
\text { gulho } \\
+ \\
\text { Areia } \\
\text { grossa } \\
\text { (\% em } \\
\text { massa) }\end{array}$ & $\begin{array}{c}\text { Areia } \\
\text { média } \\
\text { (\% em } \\
\text { massa) }\end{array}$ & $\begin{array}{c}\text { Areia } \\
\text { fina }\end{array}$ & $\begin{array}{c}\text { Silte } \\
\text { (\% em } \\
\text { massa) }\end{array}$ & $\begin{array}{l}\text { Argila } \\
\text { (\% em } \\
\text { massa) }\end{array}$ & $\begin{array}{c}\text { LL } \\
\text { (\% em } \\
\text { massa) }\end{array}$ & $\begin{array}{c}\text { LP } \\
\text { (\% em } \\
\text { massa) }\end{array}$ & $\begin{array}{c}\text { IP } \\
\text { (\% em } \\
\text { massa) }\end{array}$ & HRB \\
\hline ST-01 & 1 & 35,8 & 9,9 & 21,3 & 17,4 & 22,6 & 31 & 18 & 13 & $A-6$ \\
\hline ST-03 & 2 & 48,9 & 18,1 & 17,0 & 14,6 & 1,5 & $\mathrm{NL}$ & $\mathrm{NP}$ & - & $A-1-b$ \\
\hline ST-03 & 3 & 41,7 & 14,5 & 8,6 & 12,9 & 22,3 & 35 & 22 & 13 & A - 6 \\
\hline
\end{tabular}

Tabela 11 - Resumo dos ensaios de caracterização

\begin{tabular}{|c|c|c|c|c|c|c|c|c|}
\hline \multirow{2}{*}{ Amostra } & \multicolumn{3}{|c|}{ Compactação na energia normal } & \multicolumn{2}{c|}{ CBR } & \multicolumn{2}{c|}{ Expansão } \\
\cline { 2 - 9 }$(\mathbf{n})$ & máximo & $\begin{array}{c}\text { Umidade } \\
\text { ótima } \\
\left(\mathbf{g} / \mathbf{c m}^{3}\right)\end{array}$ & $\begin{array}{c}\text { no CBR } \\
\text { máximo } \\
\text { massa) }\end{array}$ & $\begin{array}{c}\text { Umidade } \\
\text { no CBR } \\
\text { máximo } \\
\left(\mathbf{g} / \mathbf{c m}^{3}\right)\end{array}$ & $\begin{array}{c}\text { Na } \\
\text { (\% em } \\
\text { massa) } \\
\text { úmida- } \\
\text { de } \\
\text { ótima }\end{array}$ & Máximo & $\begin{array}{c}\text { Namida- } \\
\text { de } \\
\text { ótima }\end{array}$ & $\begin{array}{c}\text { No CBR } \\
\text { máximo }\end{array}$ \\
\hline 1 & 1,685 & 18,9 & 1,660 & 17,8 & 11 & 15 & 0,22 & 0,32 \\
\hline 2 & 1,905 & 12,5 & 1,840 & 11,2 & 12 & 20 & 0,20 & 0,45 \\
\hline 3 & 1,690 & 16,8 & 1,686 & 16,2 & 8 & 11 & 0,19 & 0,29 \\
\hline
\end{tabular}

Tabela 12 - Resumo dos ensaios de compactação e CBR 


\subsubsection{Classificação pelo Método MCT}

Nogami e Villibor (1980, 1985) desenvolveram a metodologia MCT (Miniatura, Compactado, Tropical), visando adaptar alguns índices tradicionais como granulometria e limites de Atterberg, LL (Limite de Liquidez) e LP (Limite de Plasticidade), uma vez que nenhuma das propostas para corrigir ou até mesmo substituí-los por outros índices mais significativos teve o efeito desejável para uso em solos tropicais.

Essa metodologia leva em consideração ensaios que possibilitam o melhor aproveitamento de solos arenosos finos lateríticos em pavimentação, considerando sua boa capacidade de suporte e outras características relevantes como contração, permeabilidade e infiltrabilidade.

Os corpos de prova são moldados em cilindros de $50 \mathrm{~mm}$ de diâmetro (daí a designação Miniatura), num compactador de seção plena (daí a sigla C) e o resultado dos ensaios preconizados pelo método, permitem classificar os solos tropicais (daí o uso da sigla T).

Visando a classificação do solo do local do experimento pelo método MCT, foram realizados 05 furos em pontos pré determinados conforme se verifica na Figura 28.

As sondagens a trado foram executadas com trado de diâmetro externo 4", até ser atingida a profundidade determinada de 1,5 m. Foram realizadas as caracterizações geológicas e geotécnicas dos solos. As leituras do N.A. (nível d’água) foram ausentes não indicando a presença de água até a profundidade final (ANEXO C). 


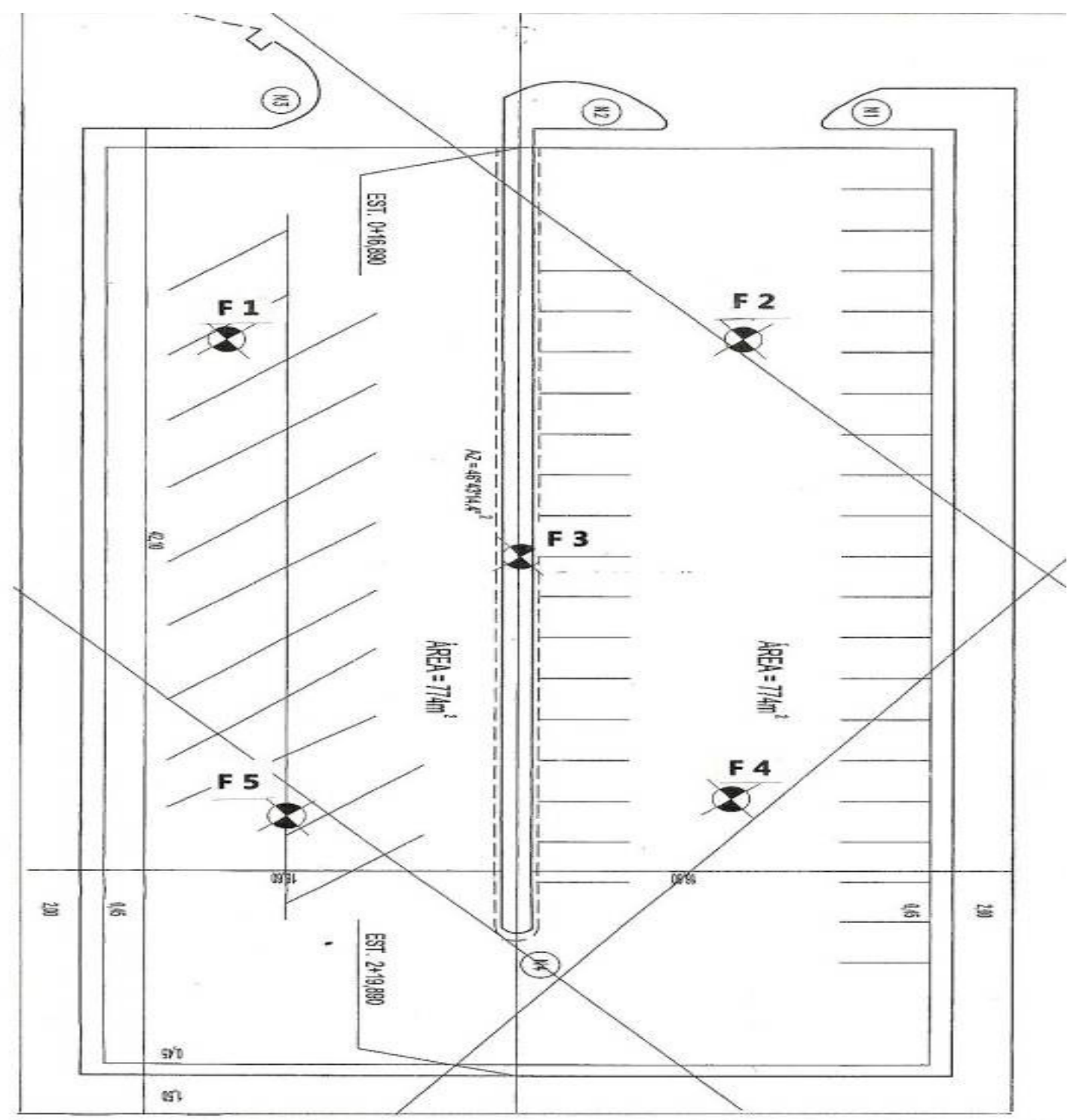

Figura 28 - Localização dos furos para classificação MCT das amostras

Ainda durante a perfuração das sondagens a trado, foram realizadas coletas de amostra de solo $(25 \mathrm{~kg})$ por trechos homogêneos atravessados, para realização de ensaios de laboratório. 
Os resultados de cada perfuração são apresentados na forma de perfis individuais de sondagem, com indicação dos materiais atravessados, leituras de nível d'água, método de perfuração e classificação geológica.

\begin{tabular}{|c|c|c|c|c|c|}
\hline Furo/Amostra no & $\mathrm{F}-01 / 01$ & $\mathrm{~F}-02 / 01$ & $\mathrm{~F}-03 / 01$ & $\mathrm{~F}-04 / 01$ & $\mathrm{~F}-05 / 01$ \\
\hline Prof. (m) & 0,20 à 1,00 & 0,20 à 1,30 & 0,20 à 1,00 & 0,20 à 1,30 & 0,20 à 1,00 \\
\hline $\begin{array}{c}\text { Classif. Táctil } \\
\text { Visual }\end{array}$ & $\begin{array}{c}\text { Areia Argilosa } \\
\text { Cinza }\end{array}$ & $\begin{array}{c}\text { Areia Argilosa } \\
\text { Marrom escura }\end{array}$ & $\begin{array}{c}\text { Areia Argilosa } \\
\text { Marrom escura }\end{array}$ & $\begin{array}{c}\text { Areia Argilosa } \\
\text { Marrom }\end{array}$ & $\begin{array}{c}\text { Areia Argilosa } \\
\text { Marrom escura }\end{array}$ \\
\hline \multicolumn{7}{|c|}{$\mathbf{( M - 1 9 6 / 8 9 )}$ Classificação MCT } \\
\hline Classif. MCT & LA/NA' & LA & LA & LA & LA \\
\hline
\end{tabular}

Tabela 13 - Resultado da classificação MCT

Legenda: LA - Laterítico arenoso

NA' - Não Laterítico

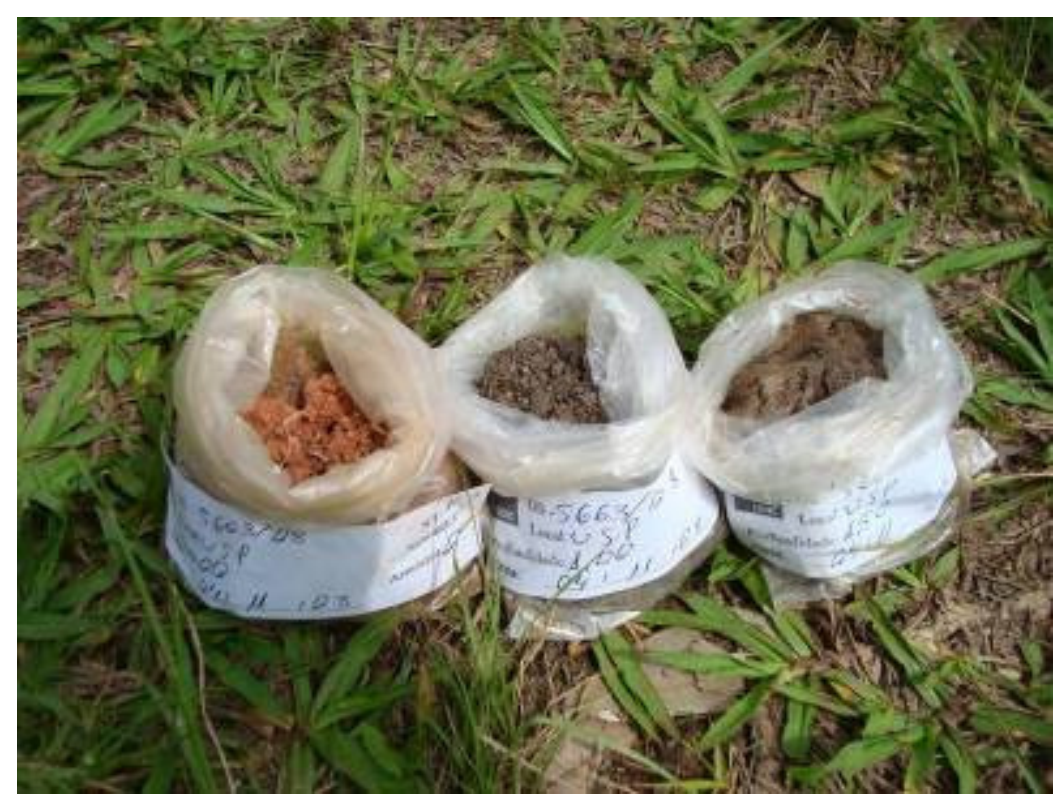

Foto 7 - Coleta de solo a 0,50, 1,00 e 1,50 metros de profundidade 


\subsubsection{Conclusão dos Serviços Geotécnicos}

De acordo com as tabelas 11, 12 e 13 nota-se que o solo, apesar de ser de aterro com diferentes horizontes geotécnicos, apresenta boa capacidade de suporte e boas condições para compactação.

Em média toda a área se apresenta com valores de CBR maiores que 10,0 (\%) ensaiados na umidade ótima. O CBR mínimo encontrado foi de 8,0\% e foi o utilizado para o dimensionamento e verificação estrutural do pavimento.

Pela classificação MCT o perfil geotécnico à profundidade média de 1,00 metro traduz-se em solo de característica areno-argilosa (lateríticos arenosos). Os solos dessa classe podem apresentar porcentagem de finos mais baixa de maneira que mesmo quando compactados, podem ser relativamente permeáveis, pouco coesivos e pouco contráteis quando secos, apesar de possuírem elevada capacidade de suporte e módulos de resiliência relativamente elevados.

Não foi encontrado lençol freático mesmo sendo os ensaios realizados na estação chuvosa em que normalmente o nível d'água encontra-se mais próximo a superfície. Este é um dado muito importante, pois a posição do nível do lençol freático é que vai determinar ou não a viabilidade da implantação dos pavimentos permeáveis. Caso o nível seja alto não há possibilidade de infiltração caso este seja o tipo de reservatório escolhido. Para reservatórios de armazenamento, o nível do aqüífero poderá gerar pressões contrárias desestabilizando o subleito e provocando depressões que põem em risco a estabilidade estrutural das camadas granulares.

Para o local do experimento foi recomendado preparar o subleito com no mínimo 15 $\mathrm{cm}$ de espessura em função da necessidade de cortar o terreno natural para a execução das camadas inferiores constituintes do reservatório. 


\subsection{Serviços Topográficos}

Para garantir a precisão da implantação do experimento, previamente foi realizado o levantamento topográfico de toda a área e seus arredores.

Visando o estabelecimento das cotas de cada camada da estrutura do pavimento, a localização de cada singularidade, a definição do grau de inclinação do leito para a captação das águas pluviais, bem como a determinação das curvas de nível do terreno natural foi efetuado levantamento com o auxilio de estação topográfica total, com coordenadas não referenciadas.

O levantamento planialtimétrico cadastral teve como objetivo a localização de cada particularidade para a determinação de possíveis interferências como o posicionamento de postes de luz, bocas de lobo, sistema de drenagem, altura de guias e sarjetas e a localização de todas as espécies arbóreas.

Através desses levantamentos prévios, pode-se realizar o projeto de implantação e todo seu detalhamento.

Ponto importante no levantamento topográfico é o correto cadastramento dos dispositivos de drenagem do sistema existente, pois com a determinação de suas cotas internas e tamanho da tubulação, pode-se projetar o sistema de saída para o lançamento final das águas captadas pelo pavimento permeável.

A seguir, a Figura 29, mostra o levantamento planialtimétrico cadastral. O desenho foi feito para prancha tamanho $\mathrm{A} 1$, porém, aqui reproduz-se em escala bem reduzida para se ter a idéia do local e do seu contorno. 


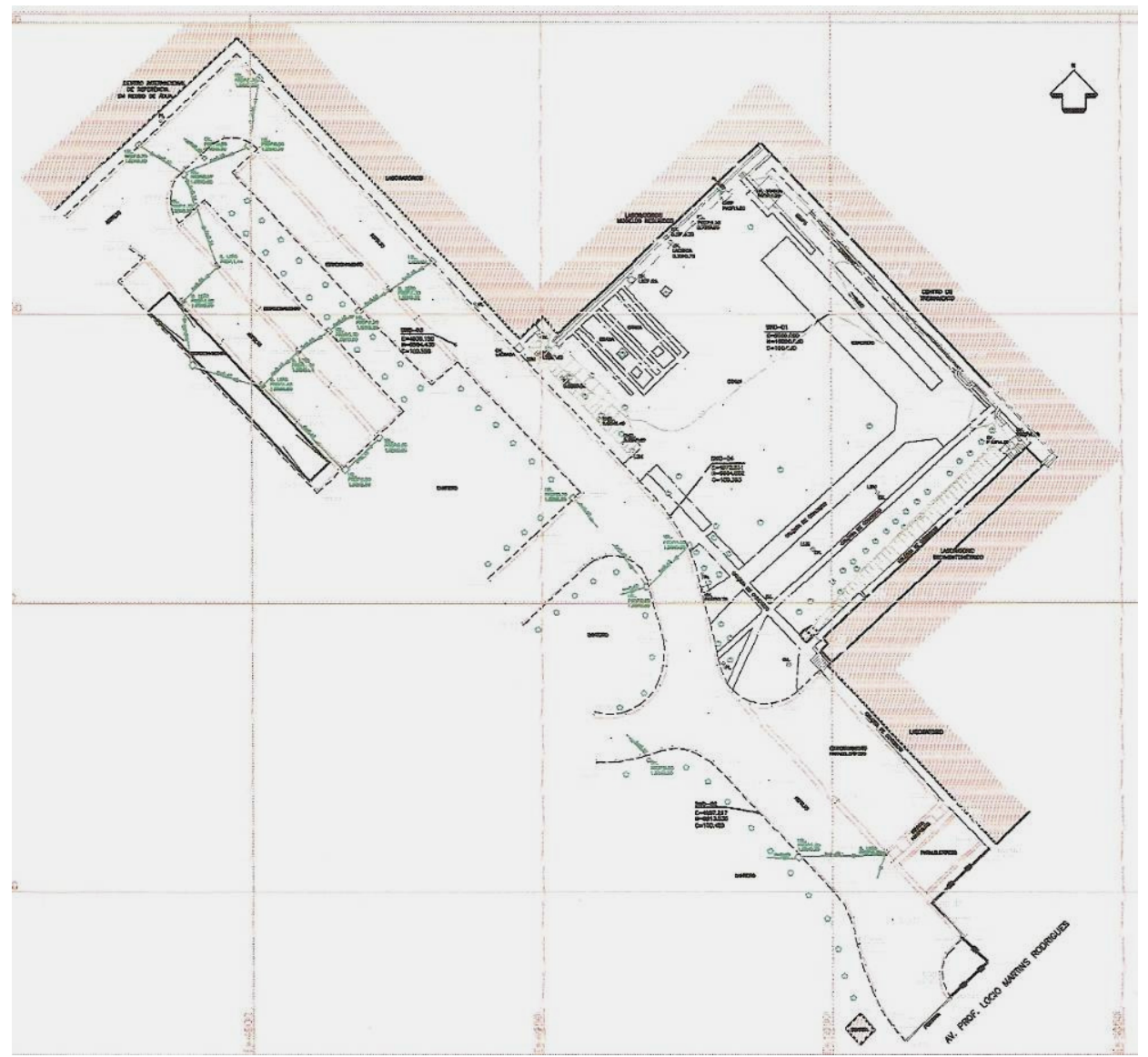

Figura 29 - Planta do levantamento planialtimétrico cadastral

\subsection{Estudos de Tráfego}

No caso específico deste trabalho, por se tratar de área de estacionamento, o tráfego foi considerado do tipo leve de acordo com o critério preconizado nos métodos de dimensionamentos de pavimentos da Prefeitura do Município de São Paulo (IP-04 - Dimensionamento de Pavimentos Flexíveis para Tráfego Leve e Médio - SIURB - Secretaria de Infraestrutura Urbana e Obras).

Para este tipo de tráfego prevê-se a circulação de até 20 veículos comerciais por dia e com até $10 \mathrm{tf}$ (toneladas força) por eixo, correspondendo a caminhões para coleta de lixo, realização de mudanças, etc. 


\subsection{Projetos Geométrico, de Terraplenagem e de Drenagem}

O projeto geométrico baseou-se em resultados de topografia e ensaios geotécnicos realizados previamente.

Especial cuidado foi tomado quanto às inclinações tanto do fundo do reservatório quanto da superfície acabada. Levou-se em consideração a execução de passeios maiores para que o pavimento não interferisse com árvores existentes no local.

Outros projetos foram complementares como o de topografia e o de corte e aterro, o projeto de drenagem partiu das cotas de fundo da GAP (galeria de águas pluviais) existente no local.

Os desenhos resultantes desses projetos constituídos de planta e seções transversais são apresentados a seguir: 


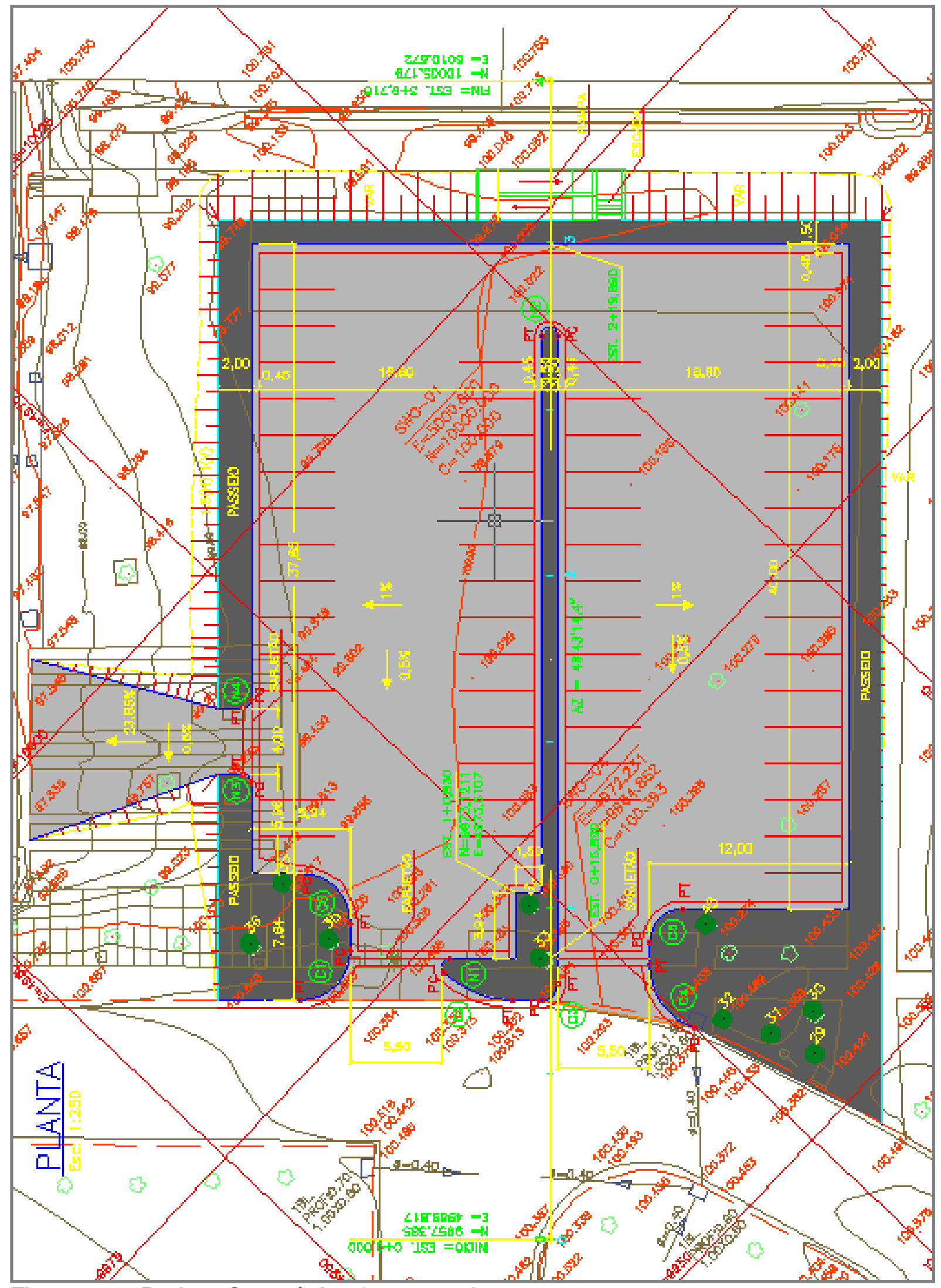

Figura 30 - Projeto Geométrico (sem escala) 


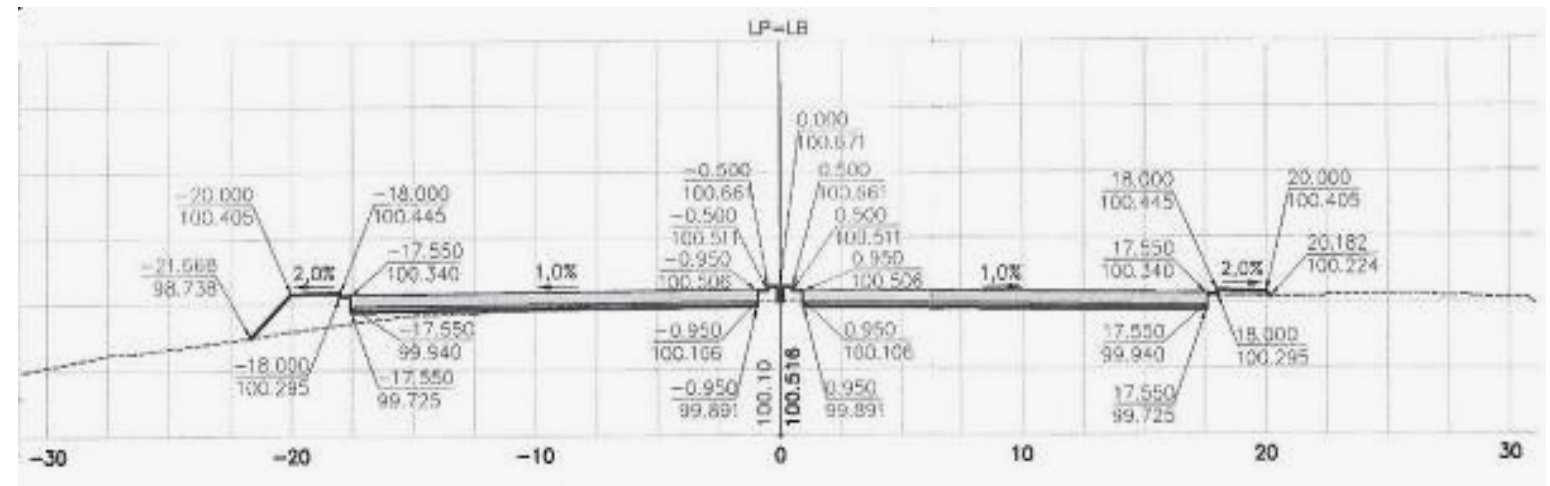

Figura 31 - Projeto Geométrico - Perfil transversal (s/escala)

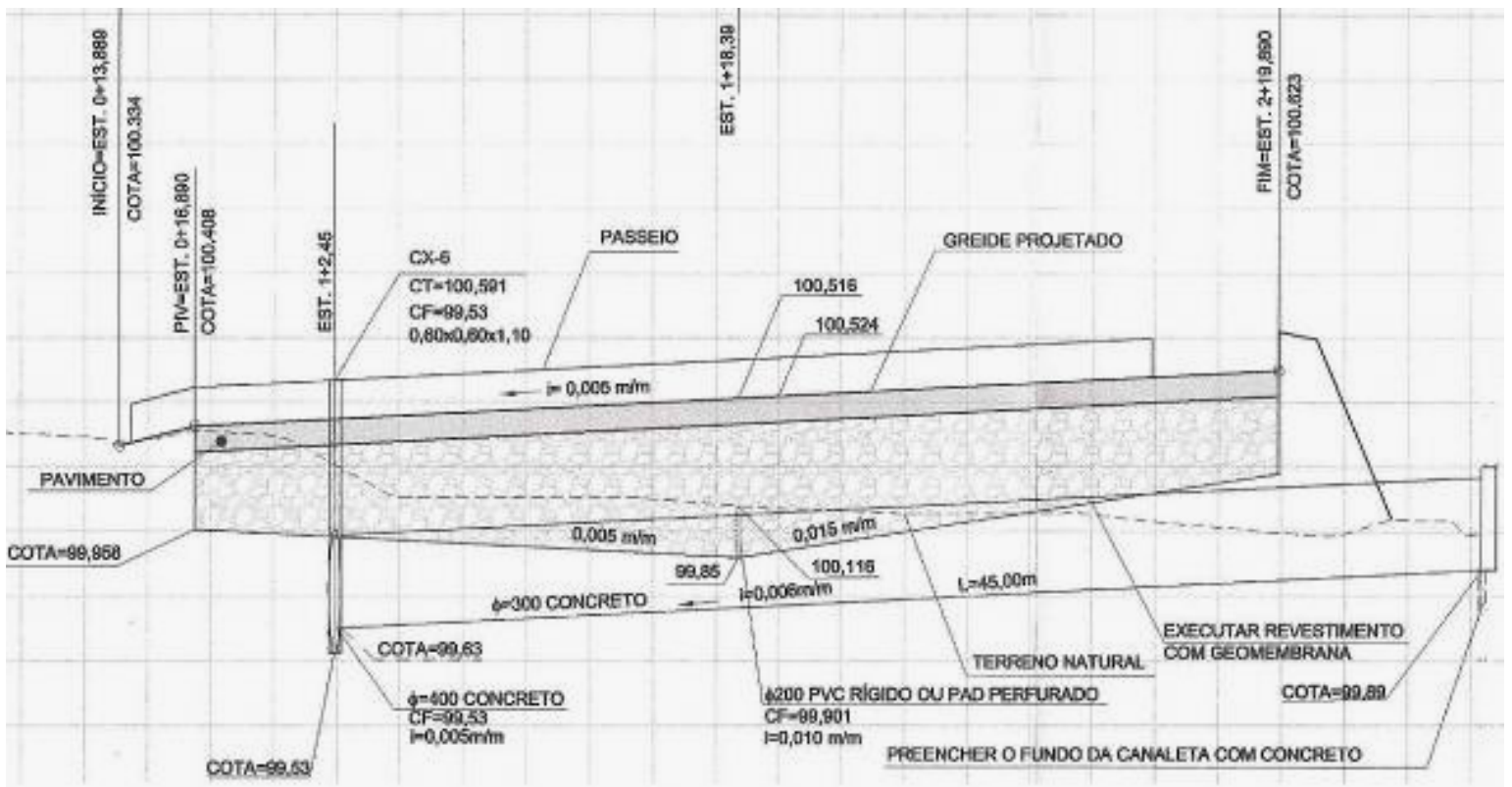

Figura 32 - Drenagem - Perfil longitudinal (s/escala) 


\subsection{Projeto de Pavimentação}

\subsubsection{Dimensionamento dos Pavimentos Flexíveis (CPA)}

De acordo com a instrução de projeto PMSP-IP-04 que trata do assunto, os serviços geológicos e geotécnicos para a caracterização do subleito deverão respeitar a Instrução de Projeto IP-01 da PMSP/SIURB.

As vias urbanas a serem pavimentadas são classificadas de acordo com a Instrução de Projeto IP-02 - Classificação das Vias da SIURB/PMSP.

Classificaçăo das Vias - Tráfego Leve e Médio

\begin{tabular}{|c|c|c|c|c|c|c|}
\hline \multirow{2}{*}{$\begin{array}{c}\text { FUNÇAO } \\
\text { PREDOMINANTE }\end{array}$} & \multirow{2}{*}{$\begin{array}{l}\text { TRÁFEGO } \\
\text { PREVISTOO }\end{array}$} & \multirow{2}{*}{$\begin{array}{c}\text { VIDA DE } \\
\text { PROJETO } \\
\text { (ANOS) }\end{array}$} & \multicolumn{2}{|c|}{$\begin{array}{l}\text { VOLUME INICIAL DA FAIXA } \\
\text { MAIS CARREGADA }\end{array}$} & \multirow{2}{*}{ N } & \multirow{2}{*}{$\mathrm{N}_{\text {caracteristico }}$} \\
\hline & & & $\begin{array}{l}\text { VEICULO } \\
\text { LEVE }\end{array}$ & $\begin{array}{l}\text { CAMINHOOES E } \\
\text { ONIBUS }\end{array}$ & & \\
\hline Via Local & Leve & 10 & $\begin{array}{c}100 \\
a \\
400\end{array}$ & $\begin{array}{c}4 \\
\mathrm{a} \\
20\end{array}$ & $\begin{array}{c}2,7 \times 10^{4} \\
a \\
1,4 \times 10^{5}\end{array}$ & $10^{5}$ \\
\hline $\begin{array}{l}\text { Via Local e } \\
\text { Coletora }\end{array}$ & Médio & 10 & $\begin{array}{c}401 \\
a \\
1500\end{array}$ & $\begin{array}{c}21 \\
\mathrm{a} \\
100\end{array}$ & $\begin{array}{c}1,4 \times 10^{5} \\
a \\
6,8 \times 10^{5}\end{array}$ & $5 \times 10^{5}$ \\
\hline
\end{tabular}

Tabela 14 - Classificação das ruas quanto ao tipo de tráfego

- Tipo de tráfego adotado $=$ Tráfego Leve $=\mathrm{N}=10^{5}$

- $\quad \mathrm{CBR}=8,0 \%$ ( CBR obtido através das sondagens). 
Com os valores de CBR e $\mathrm{N}$ inseridos no ábaco tem-se:

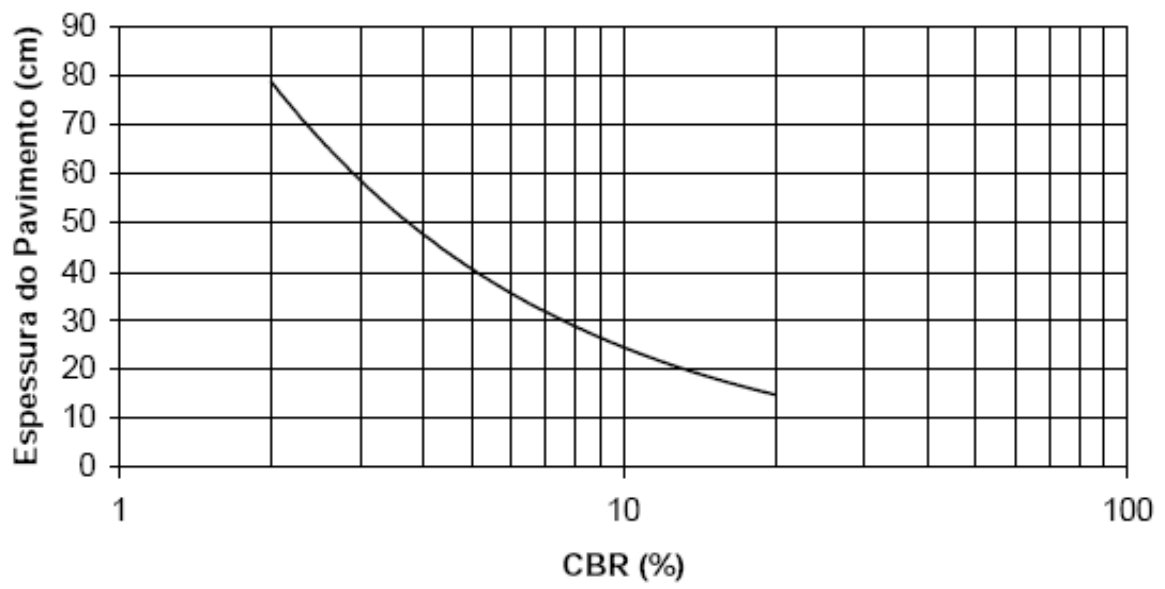

Gráfico 6 - Ábaco de dimensionamento

\begin{tabular}{|c|c|c|c|c|c|c|c|c|c|c|c|c|c|}
\hline CBR & 2 & 3 & 4 & 5 & 6 & 7 & 8 & 9 & 10 & 11 & 12 & 15 & 20 \\
\hline Heq & 79 & 59 & 48 & 41 & 35 & 32 & 29 & 27 & 25 & 23 & 21 & 18 & 15 \\
\hline
\end{tabular}
(fonte: US Army Corps of Engineers)

Tabela 15 - Valores tabelados de dimensionamento

Espessura equivalente $=\mathrm{Heq}=29 \mathrm{~cm}$

\begin{tabular}{|c|c|c|}
\hline \multirow{2}{*}{ TRÁFEGO } & TIPO DE REVESTIMENTO & ESPESSURA (R) em cm \\
\hline \multirow{2}{*}{ LEVE } & PMQ & 4,0 \\
\cline { 2 - 3 } & CAUQ & 3,5 \\
\hline
\end{tabular}

Tabela 16 - Espessuras mínimas de revestimento -

$\mathrm{Hr}=$ Espessura mínima de revestimento =3,5 para CAUQ (concreto asfáltico usinado a quente).

O Concreto Asfáltico Poroso tipo CPA será executado com $\mathrm{Hr}=5,0 \mathrm{~cm}$, tendo em vista a possibilidade de ocorrência de colmatação da camada..

A equação a ser considerada conforme o método de dimensionamento PMSP é:

$\boldsymbol{R} \cdot K_{R}+B \cdot K_{B} \geq H_{S L}$ 
Onde:

$K_{R}, K_{B}, K_{S B}, K_{R E F}$ representam os coeficientes estruturais do revestimento, da base, da sub-base e do reforço do subleito, respectivamente; $H_{S B}, H_{R E F}$ e $H_{S L}$ são as espessuras em termos de material granular, fornecidas pela Figura 33

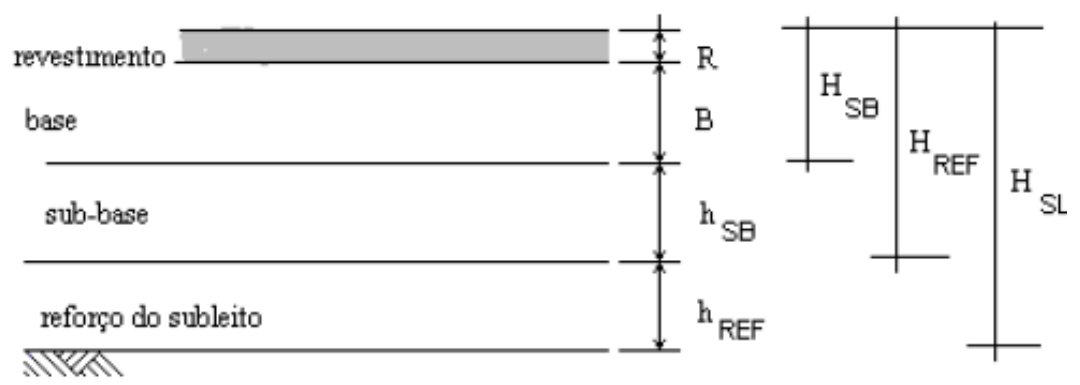

subleito

Figura 33 - Esquema elucidativo das camadas

Os valores de $K$ (Coeficientes estruturais do revestimento) são os da Tabela 17

\begin{tabular}{|l|c|}
\hline \multicolumn{1}{|c|}{ CAMADA DO PAVIMENTO } & $\begin{array}{c}\text { COEFICIENTE } \\
\text { ESTRUTURAL (K) }\end{array}$ \\
\hline Base ou Revestimento de Concreto Asfáltico & 2,00 \\
\hline Base ou Revestimento de Concreto Magro/Compactado com Rolo & 2,00 \\
\hline Base ou Revestimento de Pré-Misturado a Quente, de Graduação Densa / Binder & 1,80 \\
\hline Base ou Revestimento de Pré-Misturado a Frio, de Graduação Densa & 1,40 \\
\hline Base ou Revestimento Asfáltico por Penetração & 1,20 \\
\hline Paralelepípedos & 1,00 \\
\hline $\begin{array}{l}\text { Base de Brita Graduada Simples, Macadame Hidráulico e Estabilizadas } \\
\text { Granulometricamente }\end{array}$ & 1,00 \\
\hline Sub-bases Granulares ou Estabilizadas com Aditivos & $\leq 1,00$ \\
\hline Reforço do Subleito & $\leq 1,00$ \\
\hline $\begin{array}{l}\text { Base de Solo-Cimento ou BGTC, com resistência á compressão aos 7 dias, } \\
\text { superior a 4,5 MPa }\end{array}$ & 1,70 \\
\hline $\begin{array}{l}\text { Base de BGTC, com resistência à compressão aos 7 dias, } \\
\text { entre 2,8 e 4,5 MPa }\end{array}$ & 1,40 \\
\hline $\begin{array}{l}\text { Base de Solo-Cimento, com resistência à compressão aos 7 dias, menor } \\
\text { que 2,8 e maior ou igual a 2,1 MPa }\end{array}$ & 1,20 \\
\hline $\begin{array}{l}\text { Base de Solo melhorado com Cimento, com resistência à compressão aos 7 dias, } \\
\text { menor que 2,1 MPa }\end{array}$ & 1,00 \\
\hline
\end{tabular}

Tabela 17 - Coeficientes estruturais do revestimento

Assim, para bases de brita graduada simples, Macadame Hidráulico e estabilizadas granulometricamente tem-se: $\quad K_{B}=1,0$. 
Aplicando os valores a equação (6) tem-se:

$5 \cdot 2,0+B \cdot 1,0 \geq 29$

$B \geq 29-10 \geq 19$

Portando as camadas de base e sub-base devem ter no mínimo $19 \mathrm{~cm}$.

A espessura adotada será de $30 \mathrm{~cm}$ atendendo tanto o aspecto estrutural como o dimensionamento hidráulico para que as camadas granulares atuem como reservatório.

\subsubsection{Dimensionamento de Pavimentos com Blocos}

A norma adotada para o dimensionamento de pavimentos intertravados com blocos de concreto é a PMSP-IP-06.

Conforme considerações feitas no item anterior tem-se:

- Tipo de tráfego adotado $=$ Tráfego Leve $=\mathrm{N}=10^{5}$

- $\quad \mathrm{CBR}=8,0 \%$ ( $\mathrm{CBR}$ obtido através das sondagens).

- Procedimento A (adotado).

Este procedimento foi adaptado pela ABCP no Estudo Técnico n. 27 do trabalho original proposto pela BCA - "British Cement Association", com a utilização de bases cimentadas.

O método utiliza, para o dimensionamento da estrutura do pavimento, dois gráficos de leitura direta, fornecendo as espessuras necessárias das camadas constituintes do pavimento. 
O Gráfico 7 fornece as espessuras necessárias de sub-base em função do valor de CBR do subleito e do número "N" de solicitações conforme ABCP -ET n.27.

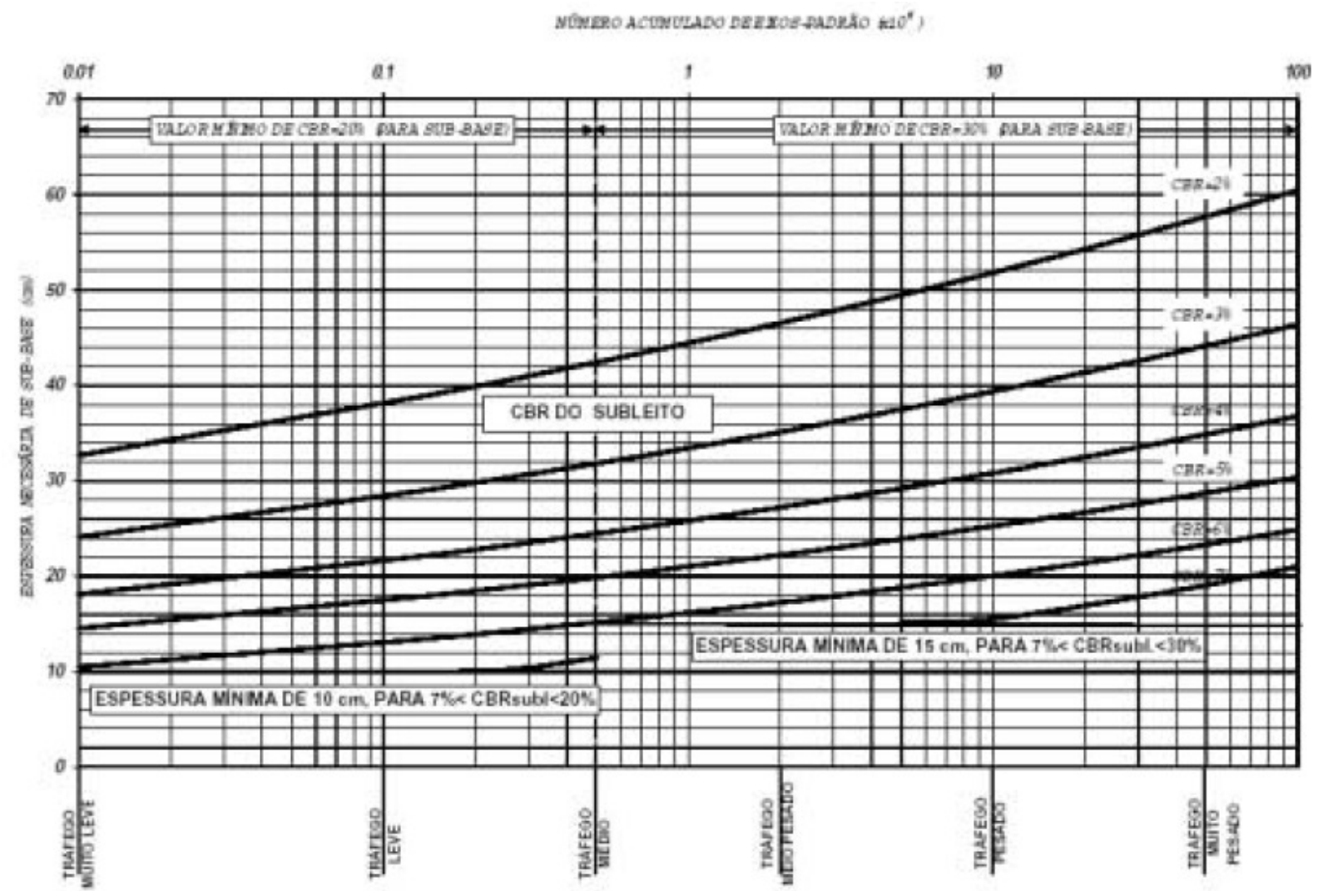

Gráfico 7 - Espessuras necessárias de sub- base.

Espessura de base B mínima $=10 \mathrm{~cm}$

Altura do bloco de concreto $=6 \mathrm{~cm}$ com resistência à compressão $\mathrm{Fcs} \geq 25 \mathrm{MPa}$.

No presente estudo a resistência a compressão refere-se a PPCs porosas desenvolvidas em conjunto com a ABCP. Daí estarmos utilizando a resistência acima, visto ser muito difícil a produção de peças de concreto poroso com resistência a compressão superior a esta por possuírem elevado índice de vazios.

A espessura B adotada $=30 \mathrm{~cm}$. 


\subsubsection{Especificações Técnicas}

A Tabela 18 a seguir, apresenta as especificações adotadas para cada camada projetada do pacote estrutural do pavimento.

\begin{tabular}{|c|c|c|}
\hline DESIGNAÇÃO & ESPECIFICAÇÃO & ANO \\
\hline Preparo do Subleito do Pavimento & PMSP IE-01 & 2004 \\
\hline Sub-Bases e Bases de Brita Graduada & PMSP ES-06 & 1992 \\
\hline Camadas de Macadame Betuminoso & PMSP ES-07 & 1992 \\
\hline Camadas de Pré Misturado a Quente & PMSP ES-10 & 1992 \\
\hline $\begin{array}{c}\text { Concreto Asfáltico Poroso com Ligante } \\
\text { Modificado por Polímero - Camada Porosa de } \\
\text { Atrito -CPA }\end{array}$ & DER/SP ET-DE-P00/028 & 2006 \\
\hline $\begin{array}{c}\text { Pavimento com Peças Pré Moldadas de } \\
\text { Concreto }\end{array}$ & PMSP ES P 22 & 1992 \\
\cline { 2 - 3 } & DER/SP ET-DEP00/048 & 2006 \\
\hline Peças de Concreto para Pavimentação & $\begin{array}{c}\text { NBR 9780 } \\
\text { NBR 9781 }\end{array}$ & 1987 \\
\hline
\end{tabular}

Tabela 18 - Especificações Técnicas de Materiais e Serviços

\section{Outras considerações}

Visando o não puncionamento da manta de PEAD (geomembrana) que será aplicada sobre o subleito reforçado, considerou-se a execução de uma camada de 5 cm de pó de pedra cuja finalidade será de atuar como colchão amortecedor, impedindo o contato direto da camada granular com o PEAD.

Portanto a espessura de todo o pacote granular será de $35 \mathrm{~cm}$. 


\subsubsection{Dosagem do CPA}

Uma vez que a usina de asfalto da empreiteira já estava calibrada para execução do CPA para ser aplicado no Trecho Sul do Rodoanel de São Paulo sob a fiscalização do DERSA, foram analisados os resultados dos ensaios realizados no Laboratório de Tecnologia de Pavimentos LTP da Escola Politécnica da Universidade de São Paulo, chegando-se a conclusão que o mesmo CPA, com a mesma dosagem, poderia ser aplicado no trecho experimental.

Sendo assim, a dosagem especificada apresenta as seguintes características:

Pedreira: BARUERI CAP: FLEXPAVE 65/90

CPA: Faixa Arizona - AASHTO T-27 e AASHTO T-11

\begin{tabular}{|c|c|c|c|}
\hline \multicolumn{4}{|c|}{ A ESPESSURA DA CAMADA COMPACTADA NA PISTA DEVE SER 5 CM. } \\
\hline \multicolumn{3}{|c|}{$\begin{array}{l}\text { VALORES ENCONTRADOS PARA TEOR ÓTIMO EM PESO DE } \\
\text { ASFALTO ADICIONADO (AASHTO R-35) }\end{array}$} & $4,5 \%$ \\
\hline \multicolumn{3}{|c|}{ COMPOSIÇÃO DA MISTURA SECA } & CAP-FLEXPAVE 65/90 \\
\hline BARUERI & GRANILHA $(10,0 \mathrm{~mm})$ & $93,1 \%$ & $88,9 \%$ \\
\hline BARUERI & AREIA ARTIFICIAL & $5,0 \%$ & $4,8 \%$ \\
\hline DIVERSOS & CAL CH I & $1,5 \%$ & $1,4 \%$ \\
\hline DIVERSOS & Fibra Viatop & $0,4 \%$ & $0,4 \%$ \\
\hline \multicolumn{2}{|l|}{ TOTAL } & $100,0 \%$ & $4,5 \%$ \\
\hline \multicolumn{3}{|c|}{ TOTAL GERAL } & $100,0 \%$ \\
\hline
\end{tabular}

Tabela 19 - Dosagem da Camada Porosa de Atrito 
- Faixa granulométrica e especificações

As granulometrias foram realizadas por via úmida conforme metodologia empregada pela AASHTO T-27 e AASHTO T-11, denominada Faixa Arizona.

\begin{tabular}{|c|c|c|c|c|c|c|c|}
\hline \multicolumn{7}{|c|}{ GRANULOMETRIA DA MISTURA DOS AGREGADOS - CPA } \\
\hline PENEIRA & $\mathbf{m m}$ & OBTIDO & \multicolumn{2}{|c|}{ FAIXA DE TRABALHO } & \multicolumn{2}{c|}{ LIM } & \multicolumn{2}{c|}{ FAIXA ARIZONA } \\
\hline $1 ”$ & 25,00 & 100 & 100 & 100 & \pm 7 & 100 & 100 \\
\hline $1 ”$ & 25,00 & 100 & 100 & 100 & \pm 7 & 100 & 100 \\
\hline $5 / 8 ”$ & 15,90 & 100 & 100 & 100 & \pm 7 & 100 & 100 \\
\hline 1/2" & 12,70 & 100 & 100 & 100 & \pm 7 & 100 & 100 \\
\hline $3 / 8 ”$ & 9,52 & 99 & 100 & 100 & \pm 5 & 100 & 100 \\
\hline №4 & 4,76 & 28 & 28 & 33 & \pm 5 & 30 & 46 \\
\hline №8 & 2,40 & 8 & 3 & 9 & \pm 5 & 3 & 9 \\
\hline №30 & 0,60 & 5 & 2 & 6 & \pm 3 & 2 & 6 \\
\hline №200 & 0,075 & 3 & 1 & 3 & \pm 2 & 0 & 3 \\
\hline
\end{tabular}

Tabela 20 - Granulometria CPA -Faixa Arizona

\section{Especificação}

Os agregados foram fracionados (segundo porcentagens definidas), nas peneiras: $1 / 2$ " - 3/8" - no $4-n^{\circ} 8$, para a preparação individual dos corpos de prova com altura de $6,35 \pm 0,13 \mathrm{~cm}$

A compactação, com 75 golpes por face do corpo de prova, bem como a densidade Máxima da Mistura, foram executadas 2 horas após a mistura (AASHTO R-30) 


\begin{tabular}{|c|c|c|c|}
\hline \multicolumn{4}{|l|}{ ESPECIFICAÇÃO } \\
\hline \multicolumn{2}{|l|}{ ARIZONA } & \multirow{2}{*}{$\begin{array}{l}\text { MíNI } \\
4,3 \%\end{array}$} & \multirow{2}{*}{$\begin{array}{l}\text { MÁX } \\
4,7 \%\end{array}$} \\
\hline $\begin{array}{l}\text { VALORES ENCONTRADOS P/TEOR ÓTIMO EM PESO DE ASFALTO } \\
\text { ADICIONADO (AASHTO R-35) }\end{array}$ & $4,5 \%$ & & \\
\hline TEOR ÓTIMO MDE ASFALTO EFETIVO, APÓS 2 H DA MISTURA (AASHTO R-35) & $4,5 \%$ & & \\
\hline ABSORÇÃO DE ASFALTO PELO AGREGADO (AASHTO R-35) & $0,0 \%$ & & \\
\hline DENSIDADE DO ASFALTO CAP FLEXPAVE 65/90 (AASHTO T-228) & $1,018 \mathrm{~g} / \mathrm{cm}^{3}$ & & \\
\hline $\begin{array}{l}\text { TAMANHO MÁXIMO NOMINAL DO AGREGADO COMBINADO PARA 90\% } \\
\text { PASSANDO (mm) (AASHTO m-323) }\end{array}$ & $12,5 \mathrm{~mm}$ & & \\
\hline ESPECIFICAÇÃO DA MISTURA DA CAMADA COMPACTADA NA PISTA $(\mathrm{cm})$ & $\mathrm{cm}$ & 3,0 & 5,0 \\
\hline DENSIDADE APARENTE DOS AGREGADOS COMBINADOS (MS-4 ) Cap. $4^{*}$ & $2,, 693 \mathrm{~g} / \mathrm{cm}^{3}$ & & \\
\hline DENSIDADE EFETIVA DOS AGREGADOS COMBINADOS (MS-4) Cap. $4^{*}$ & $2,687 \mathrm{~g} / \mathrm{cm}^{3}$ & & \\
\hline DENSIDADE APARENTE DA MISTURA COMPACTADA (AASHTO T-275) & $1,998 \mathrm{~g} / \mathrm{cm}^{3}$ & & \\
\hline DENSIDADE MÁXIMA DA MISTURA (SEM VAZIOS) (MS-4) Cap. $4^{*}$ & $2,502 \mathrm{~g} / \mathrm{cm}^{3}$ & & \\
\hline TEOR DE VAZIOS DE AR (Va \%) (AASHTO R-35) & $20,1 \%$ & $20 \%$ & $22 \%$ \\
\hline VAZIOS DO AGREGADO MINERAL (VAM \%) (AASHTO M-323) & $29,1 \%$ & & \\
\hline VAZIOS CHEIOS DE ASFALTO (VCA \%) (AASHTO M-323) & $30,9 \%$ & $60 \%$ & $70 \%$ \\
\hline $\begin{array}{l}\text { RESISTÉNCIA A TRAÇÃO POR COMPRESSÃO DIAMETRAL DNIT-ME-138-ASTM } \\
\text { C } 496\end{array}$ & 7,2 daPA & & \\
\hline RELAÇÃO FILLER /LIGANTE (AASHTO M-323) & 0,7 & & \\
\hline $\begin{array}{l}\text { PORCENTAGEM DE ASFALTO EM VOLUME/VOLUME TOTAL DE MASSA } \\
\text { (ADICIONADO) }\end{array}$ & $11,1 \%$ & 10,6 & 11,6 \\
\hline DESGASTE CANTABRO (DNER ME - 383) & $12,0 \%$ & & \\
\hline
\end{tabular}

Tabela 21 - Especificações do CPA - Faixa Arizona

*(MS-4)= Instituto de Asfalto - Manual de Asfalto - Série 4 Edição 1989

Observa-se que o Teor de Vazios de $\operatorname{Ar}(\mathrm{Va} \%$ ) especificado é de $20,1 \%$ que permite a infiltração de água através de seus vazios comunicantes. 


\subsubsection{Perfil Final adotado para a Obra}

Uma vez que a eficiência do funcionamento da geomembrana impermeável é de suma importância, foram contatados fabricantes que expuseram suas preocupações sobre o puncionamento da manta que poria em risco os resultados do experimento, temia-se sua ruptura quando o macadame hidráulico fosse espalhado, por isso decidiu-se acrescentar mais uma camada extra de $5 \mathrm{~cm}$ de areia fina acima da geomembrana para proteger um pouco mais a geomembrana de perfurações.

A espessura das camadas granulares permaneceu com $35 \mathrm{~cm}$, como dimensionada anteriormente, porém a espessura individual de algumas camadas foi alterada.

Por esta razão, na Área B (PPC de blocos intertravados de concreto), optou-se por reduzir a camada de $B G S$ de $15 \mathrm{~cm}$ para $10 \mathrm{~cm}$. A faixa $B$ da DERSA é pouco mais fechada que a faixa $A$ do $D E R$, porém, visto não haver disponibilidade da faixa mais aberta no mercado, adotou-se a brita graduada da faixa B DERSA.

Na Área C (Concreto asfáltico poroso tipo CPA) optou-se por reduzir a camada de macadame hidráulico de $30 \mathrm{~cm}$ para $25 \mathrm{~cm}$.

O perfil de execução final passou a ser: 


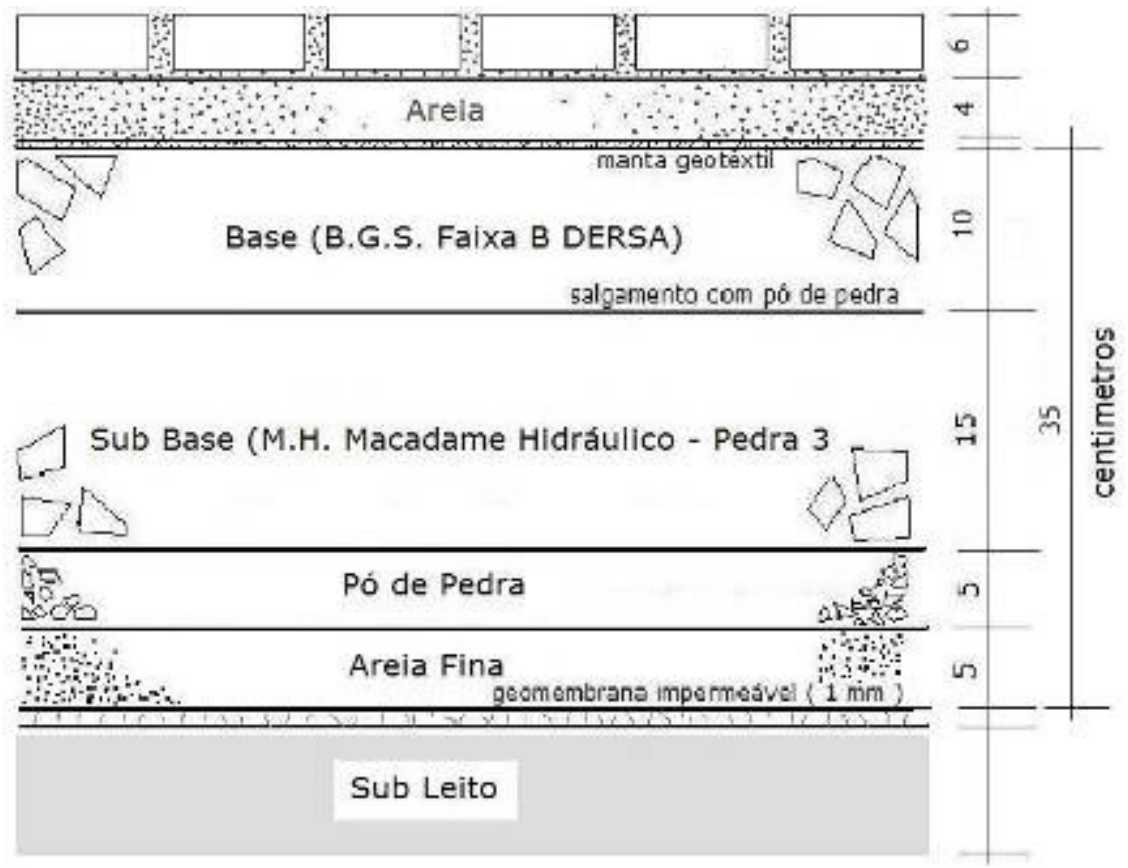

Figura 34 - Perfil da Área B - PPC -Blocos Intertravados de Concreto
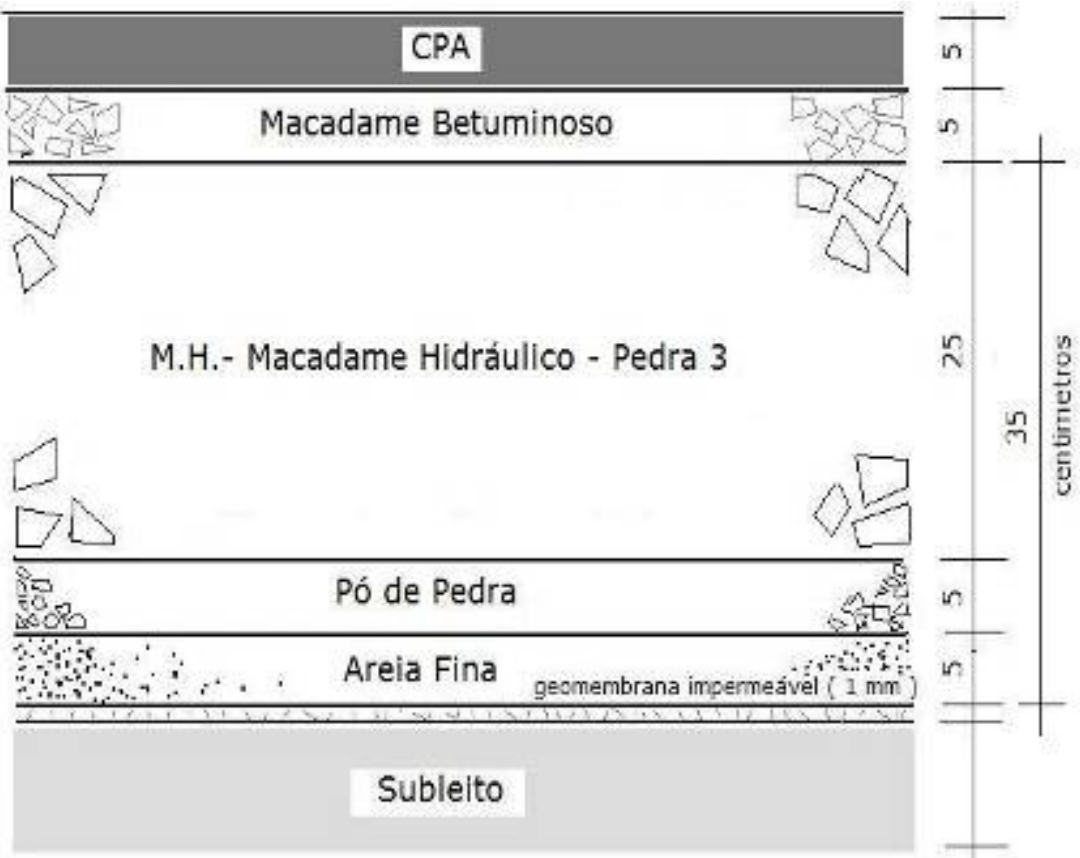

Figura 35 - Perfil da Área C - Concreto asfáltico poroso tipo CPA 
Cabe salientar que, por razões construtivas, a areia fina não foi apropriada pois seus $5 \mathrm{~cm}$ não eliminavam as dobras e o enrugamento da geomembrana, permitindo a formação de pequenas bacias ou poças que impediriam que a água infiltrada escoasse para o dreno.

Por esse motivo mudou-se o método construtivo para apenas uma camada de proteção de $10 \mathrm{~cm}$ de pó de pedra aplicada diretamente sobre a geomembrana.

Observou-se que a geomembrana deve ser soldada em panos sucessivos e preferencialmente de pouca área, a medida que o pó de pedra é lançado, pois essa é a maneira mais aconselhável para a eliminação dos enrugamentos.

\subsection{Transplante de Espécies Arbóreas}

Tomou-se especial cuidado com a manutenção de espécies arbóreas sendo que aquelas que realmente interferiram foram submetidas ao exame e aprovação dos engenheiros agrônomos da Prefeitura de São Paulo com a finalidade de transplantálas para outro local.

Técnicos da SVMA - Secretaria do Verde e Meio Ambiente compareceram ao local para fazer a classificação de 44 espécies existentes no entorno além das 02 que deveriam ser removidas e replantadas.

Com a orientação do DEPAVE - Departamento de Parques e Áreas Verdes e seus engenheiros agrônomos elaborou-se projeto de transplante e compensação ambiental que foi realizado antes da limpeza do terreno e abertura de caixa para pavimentação. Este projeto gerou o TCA - Termo de Compensação Ambiental firmado entre a SIURB e SVMA. (Anexo A)

Foram transplantadas 01 Goiabeira e 01 Ingá para os locais determinados pelo DEPAVE. Além disso, foram plantadas mudas de outras espécies de arvores na área que contorna o estacionamento como Termo de Compensação Ambiental (TCA). 
As mudas, no total de 14, foram plantadas nos canteiros ao redor da área de estacionamento, sendo que, de acordo com a Portaria 26/SVMA-G/2008, estas deverão receber acompanhamento por 02 anos dos agrônomos da Secretaria do Verde e Meio Ambiente, período no qual espera-se ser suficiente para o crescimento saudável das espécies plantadas.

A foto abaixo mostra a vista geral do local e algumas dessas árvores antes de serem transplantadas e logo após.

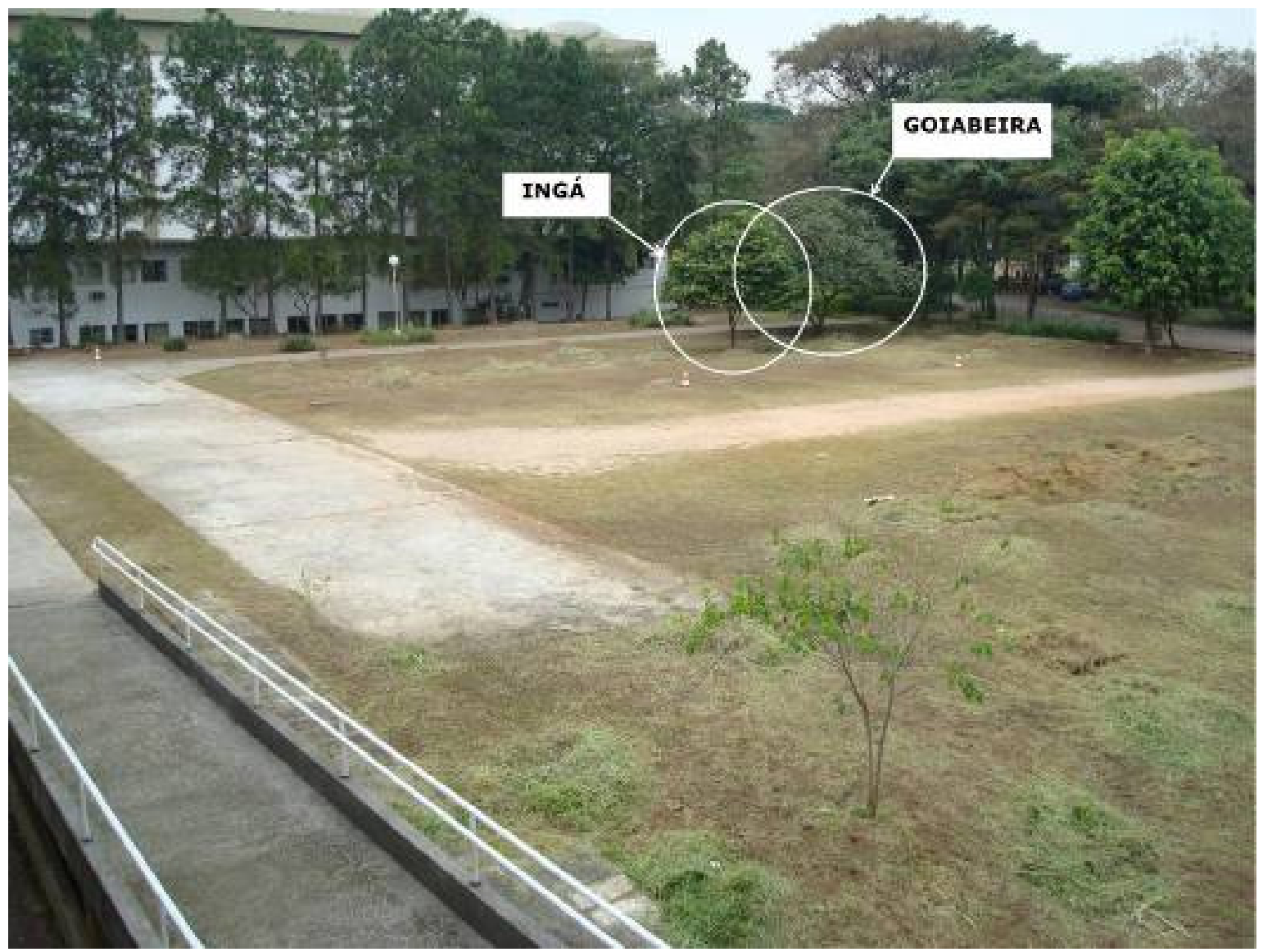

Foto 8 - Local do experimento - Antes do transplante das árvores. 


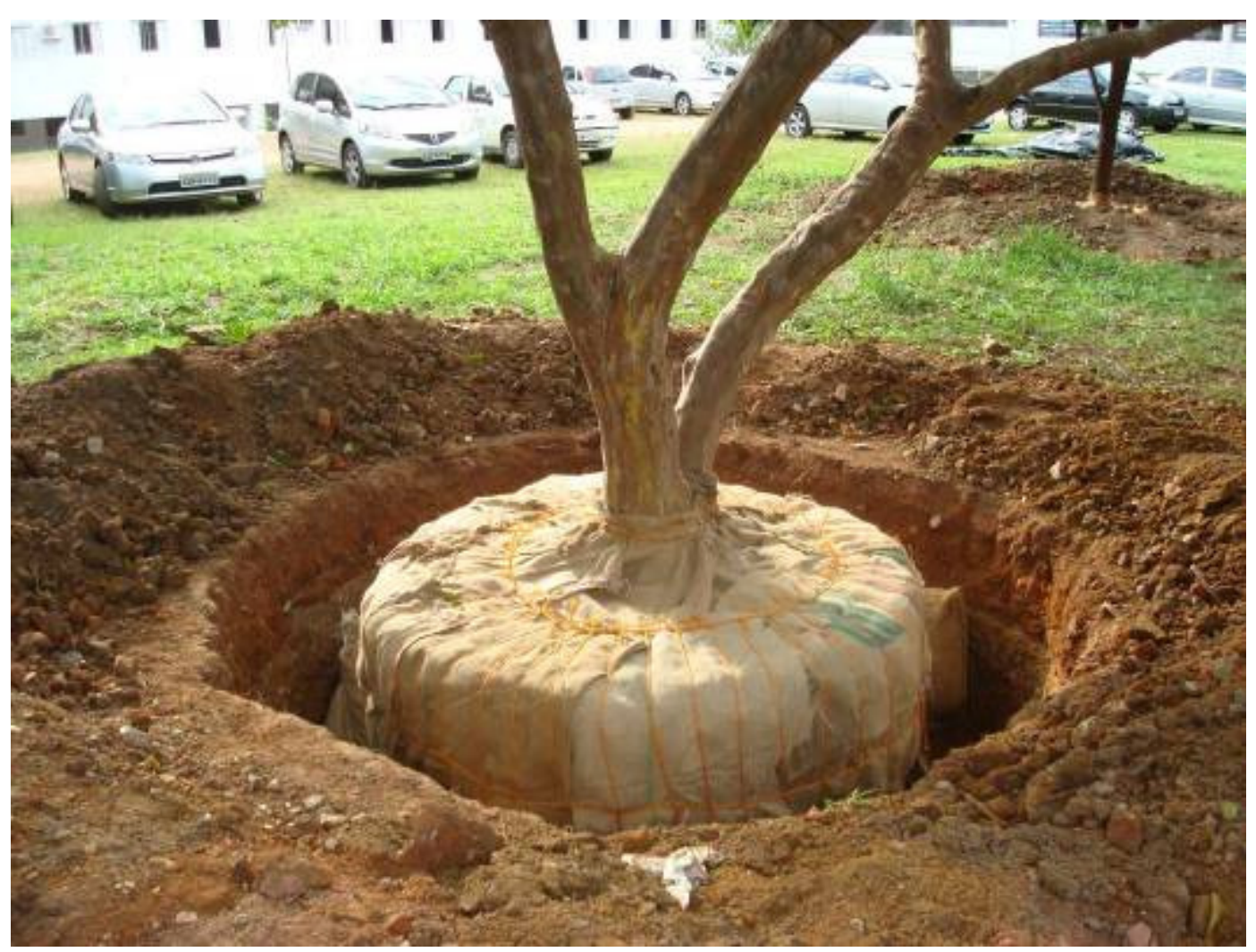

Foto 9 - Preparação do torrão para o transplante

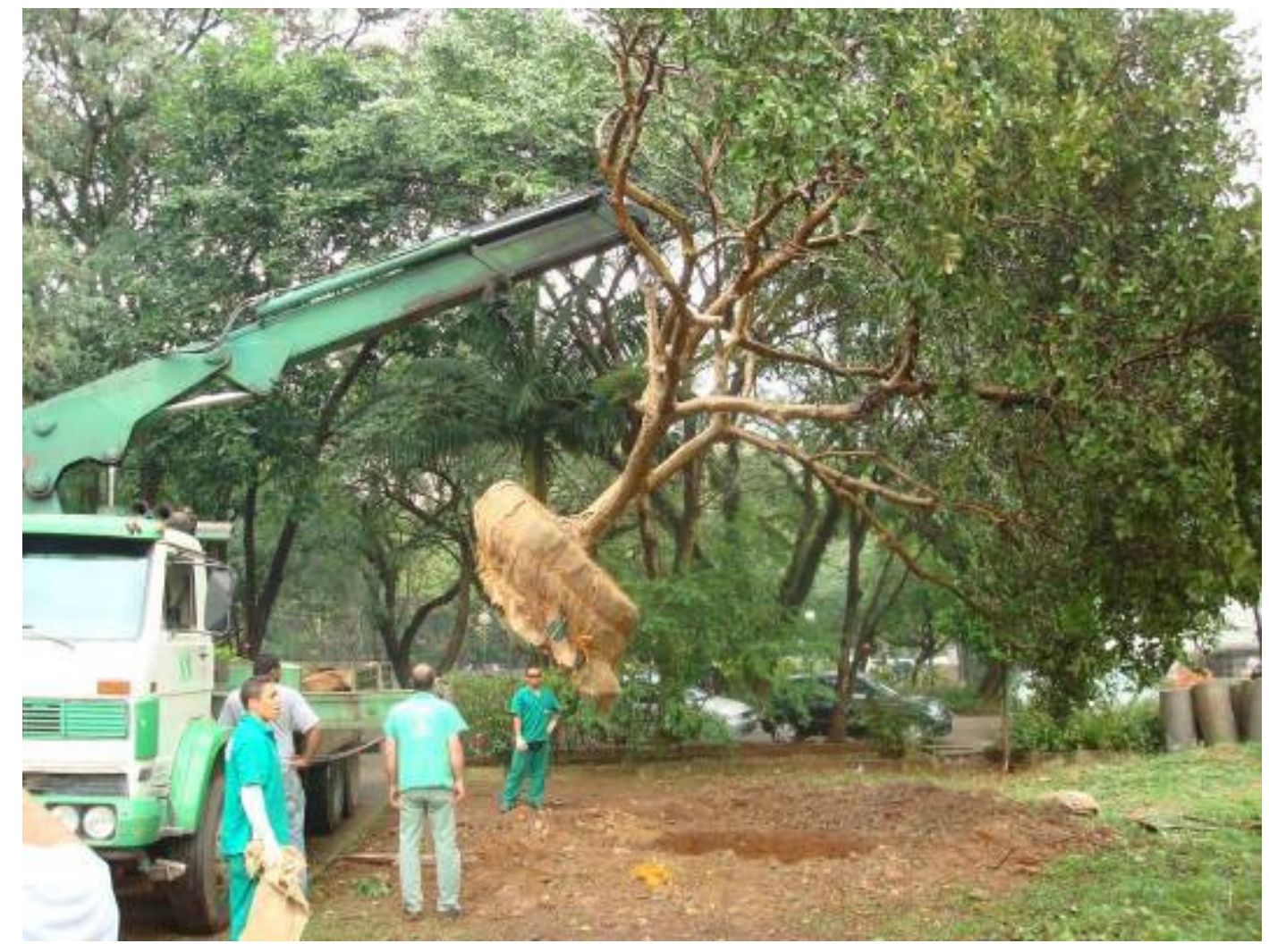

Foto 10 - Remoção através de guindaste Munk 


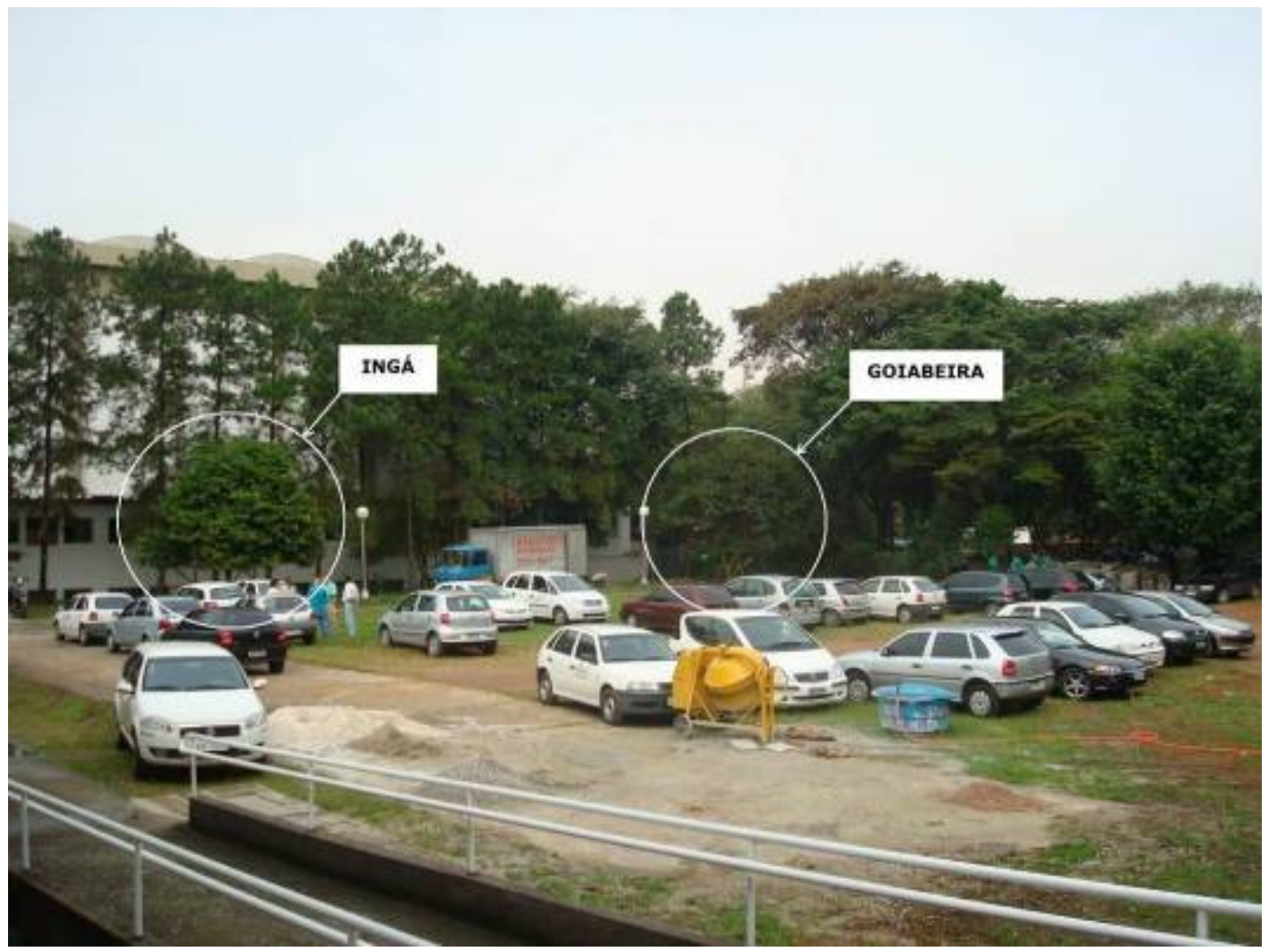

Foto 11 - Local do experimento - Depois do transplante das árvores

\subsection{Medição da Permeabilidade do Revestimento Poroso}

A permeabilidade constitui-se em importante parâmetro para avaliar a capacidade drenante da camada porosa de possibilitar percolação de água precipitada.

Campos (1998) adotou um procedimento simplificado para avaliação da permeabilidade da mistura porosa.

O ensaio foi desenvolvido pelo laboratório do DERSA - Desenvolvimento Rodoviário S. A. e constituiu em retirar corpos de prova do revestimento, encaixá-los em um tubo de mesmo diâmetro do corpo de prova e impermeabilizar os pontos de contato, de forma que a água passasse apenas pelas suas faces. Impõe-se uma coluna d'água constante e mede-se a vazão, deduzindo-se a permeabilidade. 
Para o experimento no $\mathrm{CTH}$, o ensaio de permeabilidade do concreto asfáltico poroso tipo CPA feito com as amostras recolhidas indicou o seguinte coeficiente utilizando o mesmo método de Campos (1998):

\begin{tabular}{|c|c|}
\hline Ano & Permeabilidade $\left(\mathbf{1 0}^{-2} \mathbf{c m} / \mathbf{s}\right)$ \\
\hline 2009 & 40 \\
\hline
\end{tabular}
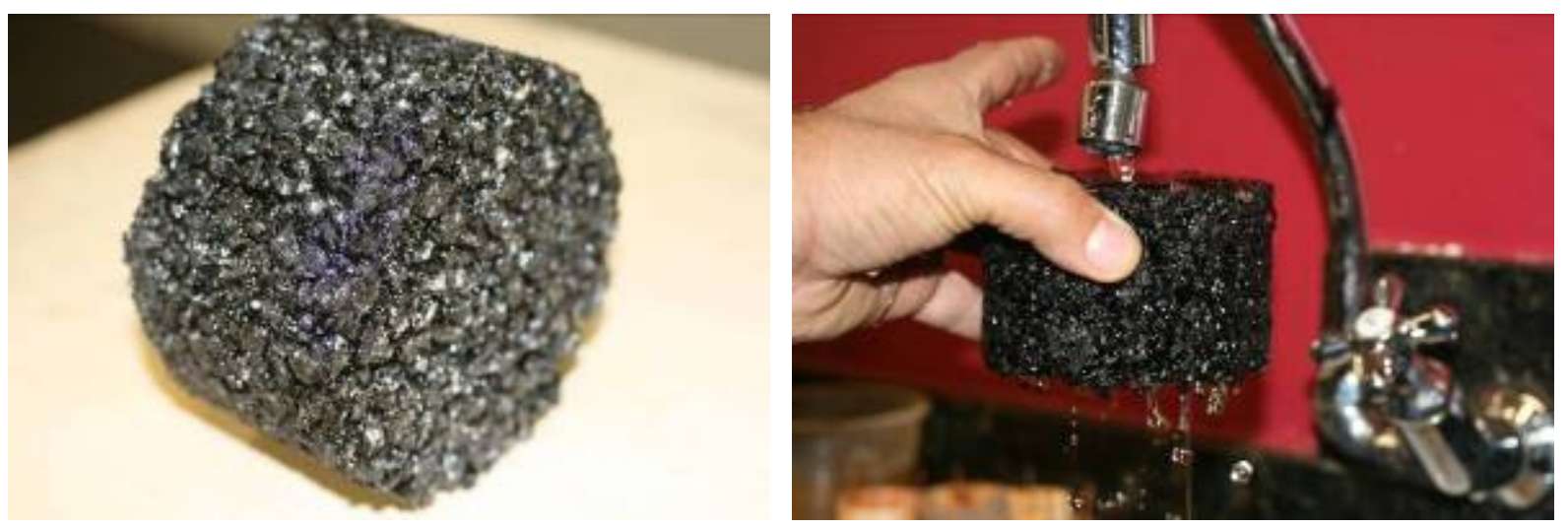

Foto 12 - Amostra de CPA e demonstração de sua permeabilidade

\begin{tabular}{|l|c|c|c|c|c|c|c|c|}
\hline \multicolumn{10}{|c|}{ Ensaio de permeabilidade de carga constante para a mistura de CPA } \\
\hline Ensaio & 1 & 2 & 3 & 4 & 5 & 6 & 7 & 8 \\
\hline Tempo (em segundos ) & 32,12 & 32,03 & 31,98 & 31,91 & 31,81 & 31,72 & 31,63 & 31,49 \\
\hline Vazão (cm 3 /s) & 31,13 & 31,22 & 31,27 & 31,34 & 31,44 & 31,53 & 31,62 & 31,77 \\
\hline Vazão média (cm 3 s) & \multicolumn{10}{|c|}{31,42} \\
\hline
\end{tabular}

Tabela 22 - Ensaios de permeabilidade do CPA

Amostra cilíndrica de diâmetro $100 \mathrm{~mm}$.

Área da superfície da amostra $=78,54 \mathrm{~cm}^{2}$

Vazão (carga constante) $=31,42 \mathrm{~cm}^{3} / \mathrm{s}$

$P=\frac{31,42}{78,54}=0,4001 \mathrm{~cm} / \mathrm{s}$ ou $40^{*} 10^{-2} \mathrm{~cm} / \mathrm{s}$

As amostras foram armazenadas em recipientes herméticos para futuros ensaios.

O valor da permeabilidade servirá de parâmetro inicial para o estudo da colmatação ao longo do tempo. 


\subsection{Comparação de Preços dos Pavimentos}

A seguir, foi elaborada a Tabela 23 , que faz a comparação entre os valores de materiais aplicados em cada tipo de pavimento, sem contemplar BDI (bonificação de despesas indiretas), mão de obra, equipamentos e transporte.

Valores de mercado - Data base JAN/2009

\begin{tabular}{|c|c|c|c|c|c|c|}
\hline \multirow{2}{*}{ MATERIAL } & \multirow[t]{2}{*}{ UN } & $\begin{array}{c}\text { PREÇO } \\
\text { UNIT }\end{array}$ & \multicolumn{2}{|c|}{ CPA } & \multicolumn{2}{|c|}{ BLOCOS } \\
\hline & & $(\mathrm{R} \$)$ & Quant $/ \mathrm{m}^{2}$ & Total $(\mathrm{R} \$)$ & Quant $/ \mathrm{m}^{2}$ & Total $(\mathrm{R} \$)$ \\
\hline Blocos Intertravados & $\mathrm{m}^{2}$ & 59,89 & & & 1,00 & 59,89 \\
\hline Concreto Asfáltico Poroso & $\mathrm{m}^{3}$ & 646,85 & 0,05 & 32,34 & & \\
\hline Macadame Betuminoso & $\mathrm{m}^{3}$ & 184,84 & 0,05 & 9,24 & & \\
\hline Pedrisco & $\mathrm{M}^{3}$ & 38,70 & 0,01 & 0,39 & & \\
\hline Imprimadura Ligante & $\mathrm{m}^{2}$ & 11,04 & 1,00 & 11,04 & & \\
\hline Geotêxtil & $\mathrm{m}^{2}$ & 14,36 & & & 1,00 & 14,36 \\
\hline BGS & $\mathrm{m}^{3}$ & 173,80 & & & 0,10 & 17,38 \\
\hline Macadame Hidráulico & $\mathrm{m}^{3}$ & 168,05 & 0,25 & 42,01 & 0,15 & 25,21 \\
\hline Pó de Pedra & $\mathrm{m}^{3}$ & 148,13 & 0,10 & 14,81 & 0,10 & 14,81 \\
\hline Geomembrana & $\mathrm{m}^{2}$ & 24,87 & 1,00 & 24,87 & 1,00 & 24,87 \\
\hline & & & TOTAL & 134,70 & TOTAL & 156,52 \\
\hline
\end{tabular}

Tabela 23 - Tabela comparativa de preços por $\mathrm{m}^{2}$

Nota-se que o valor final dos materiais constituintes do pavimento de blocos intertravados de concreto é um pouco superior ao do pavimento executado com concreto asfáltico poros tipo CPA.

O preço unitário do material concreto asfáltico poroso em si é muito maior que o preço dos blocos, este fator terá influência quando houver necessidade de algum reparo na superfície, uma vez que a execução de CPA requer equipamentos de custo elevado, mão de obra qualificada além da disponibilidade deste material na usina de asfalto e transporte. Fora isso, preliminarmente, é necessário arrancamento da superfície asfaltada ou fresagem que é um serviço dispendioso.

O valor unitário dos blocos computando-se a mão de obra para fornecimento e colocação torna-se muito menor quando comparado e, portanto, sua reabilitação é mais vantajosa. 
Mesmo que a produtividade da execução do revestimento tipo CPA seja significativamente maior durante a obra, sua reabilitação é morosa e requer muitos cuidados. Ao contrário, a execução do revestimento de blocos intertravados é lenta visto que é realizada manualmente, no entanto, a sua reabilitação é bem mais rápida e feita com os cuidados habituais e corriqueiros.

Embora neste experimento tenha sido utilizada a manta geotêxtil entre a camada de areia de assentamento e a BGS, a mesma poderá ser eliminada caso se verifique que as condições de filtro dos materiais constituintes das camadas sejam plenamente atendidas. Neste caso, os preços por $\mathrm{m}^{2}$ das duas alternativas analisadas seriam praticamente equivalentes. O preço por $\mathrm{m}^{2}$ da área $\mathrm{B}$ (blocos) seria $5,5 \%$ superior ao preço do $\mathrm{m}^{2}$ da Área C (CPA).

\subsection{Aspectos Construtivos da Obra}

\section{- Limpeza do terreno e topografia}

A limpeza foi executada com escavadeira hidráulica PC 150, retro escavadeira e caminhões basculantes. A área toda foi cercada com cerca de tela plástica em bobinas fixada em mourões de pontaletes.

Todo o material vegetal e entulho foram removidos para área de descarte e de lá para os aterros licenciados num total de $180,00 \mathrm{~m}^{3}$.

O serviço de topografia iniciou-se ao mesmo tempo fazendo a locação da obra e determinando o posicionamento das estacas de 10 em 10 metros nos sentidos longitudinal e transversal. Também foi marcada a altura de corte da camada de solo para terraplanagem e compensação entre corte e aterro. 

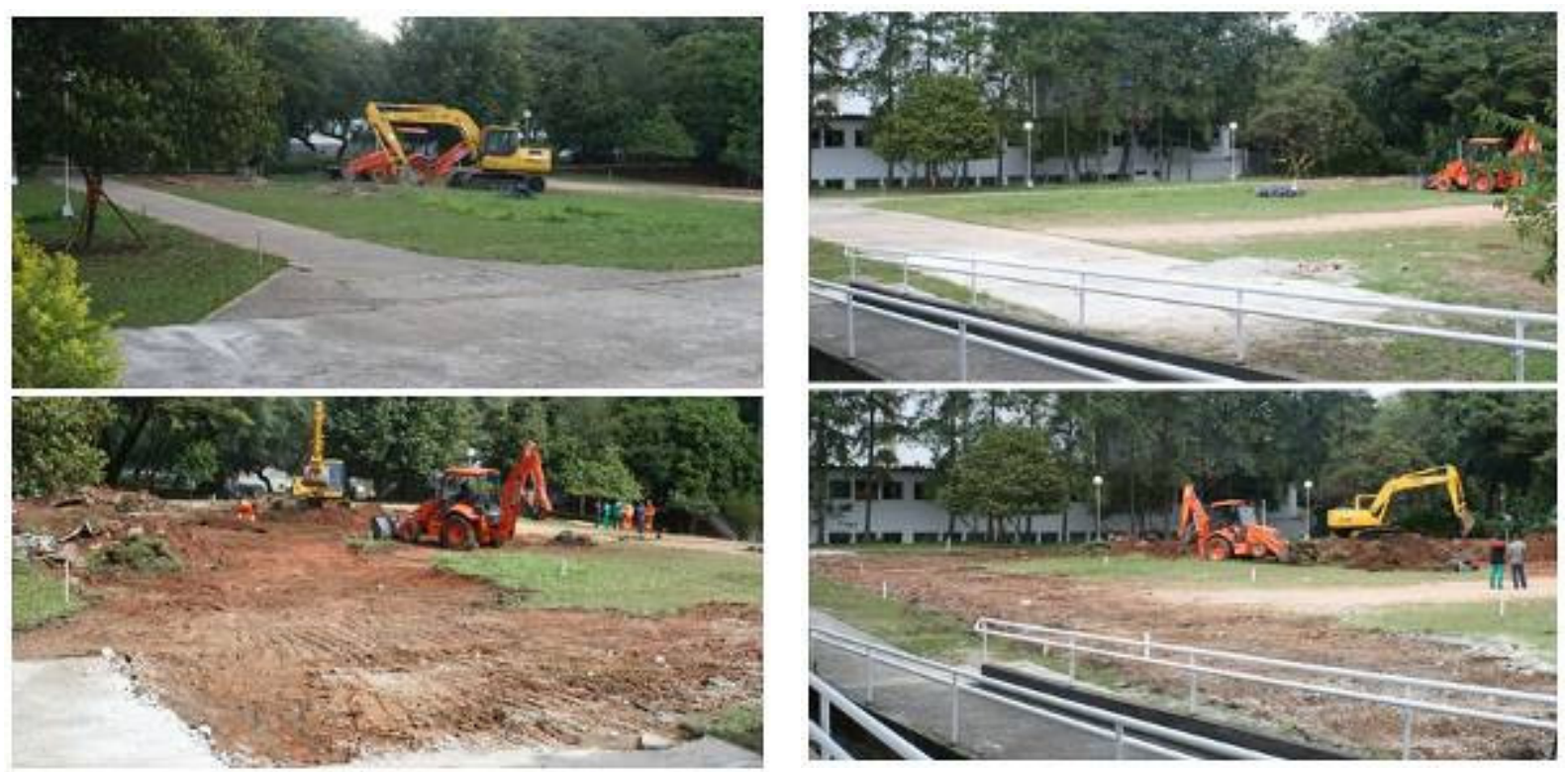

Foto 13 - Limpeza do terreno

\section{- Abertura da Caixa de Pavimentação}

Após a limpeza do terreno e locação topográfica, procedeu-se a abertura de caixa de pavimentação conforme definida em projeto para receber as várias camadas de material pétreo.
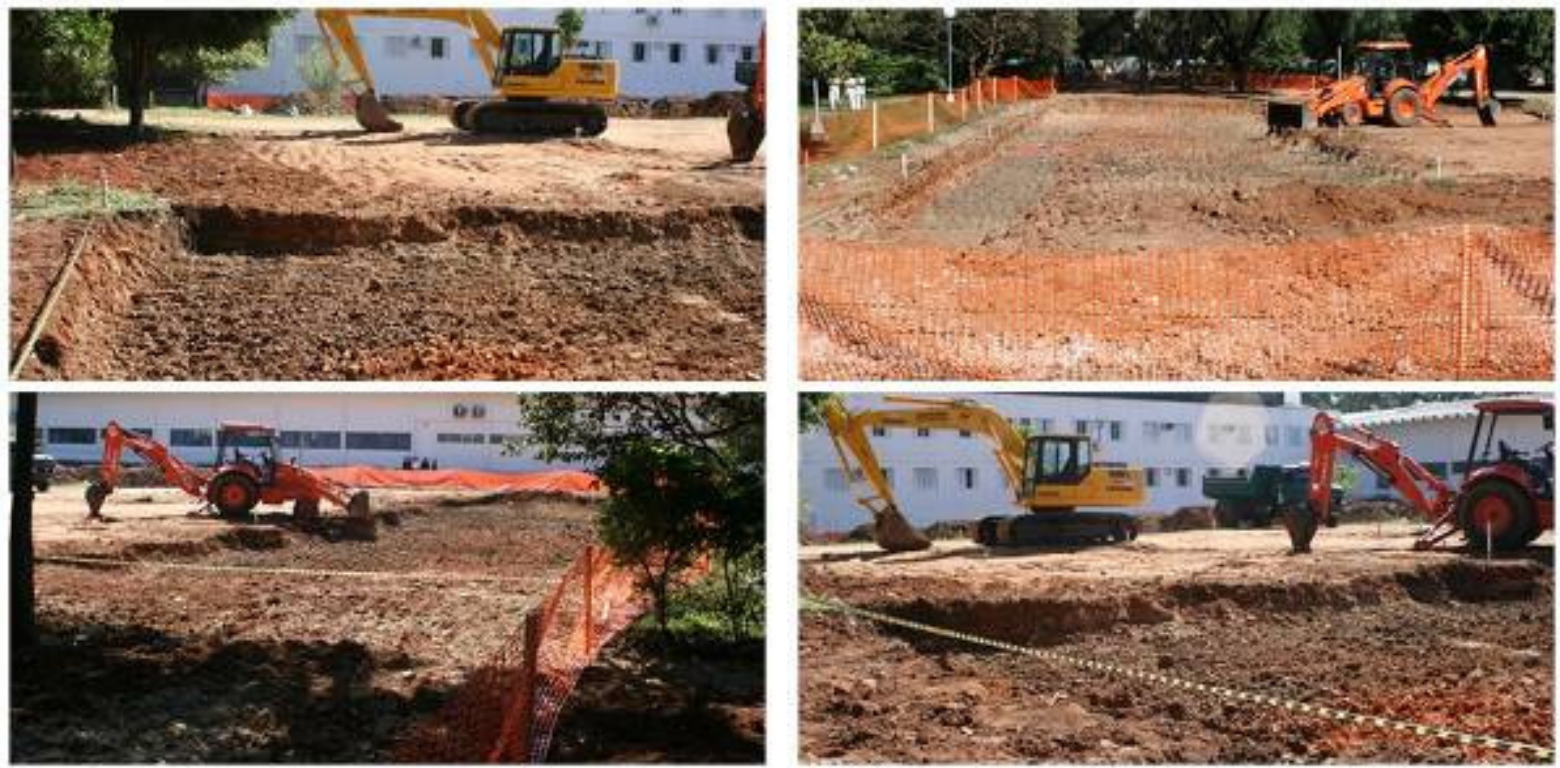

Foto 14 - Seqüência de fotos da abertura de caixa de pavimentação 


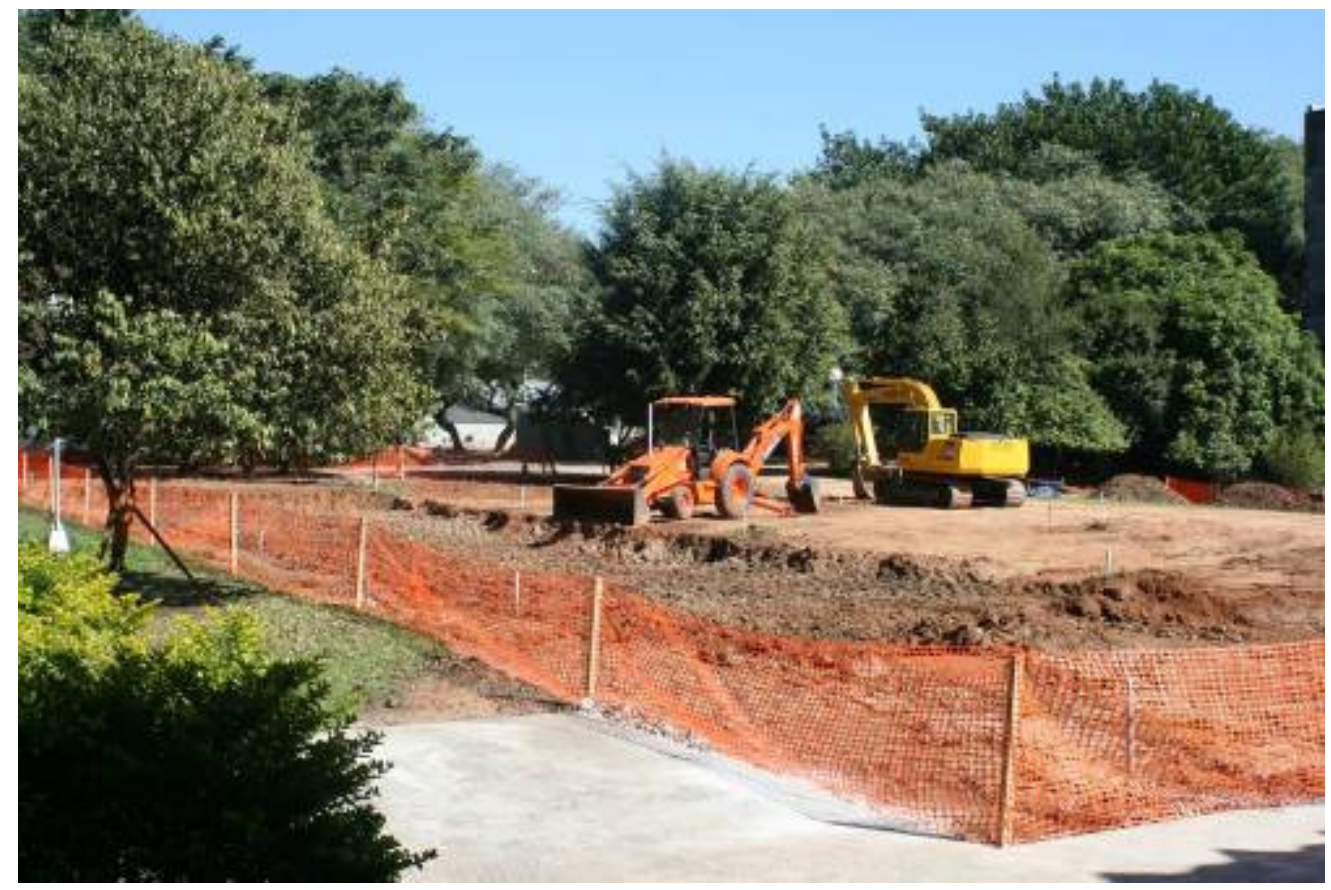

Foto 15 - Abertura de caixa de $45 \mathrm{~cm}$ de profundidade

\section{- Terraplenagem - Corte e Aterro}

Como a declividade do terreno permitia, o projeto de terraplanagem procurou otimizar os volumes de corte e aterro com o propósito de importar o menor volume de terra possível. Depois disso toda a área foi compactada para preparar o subleito.
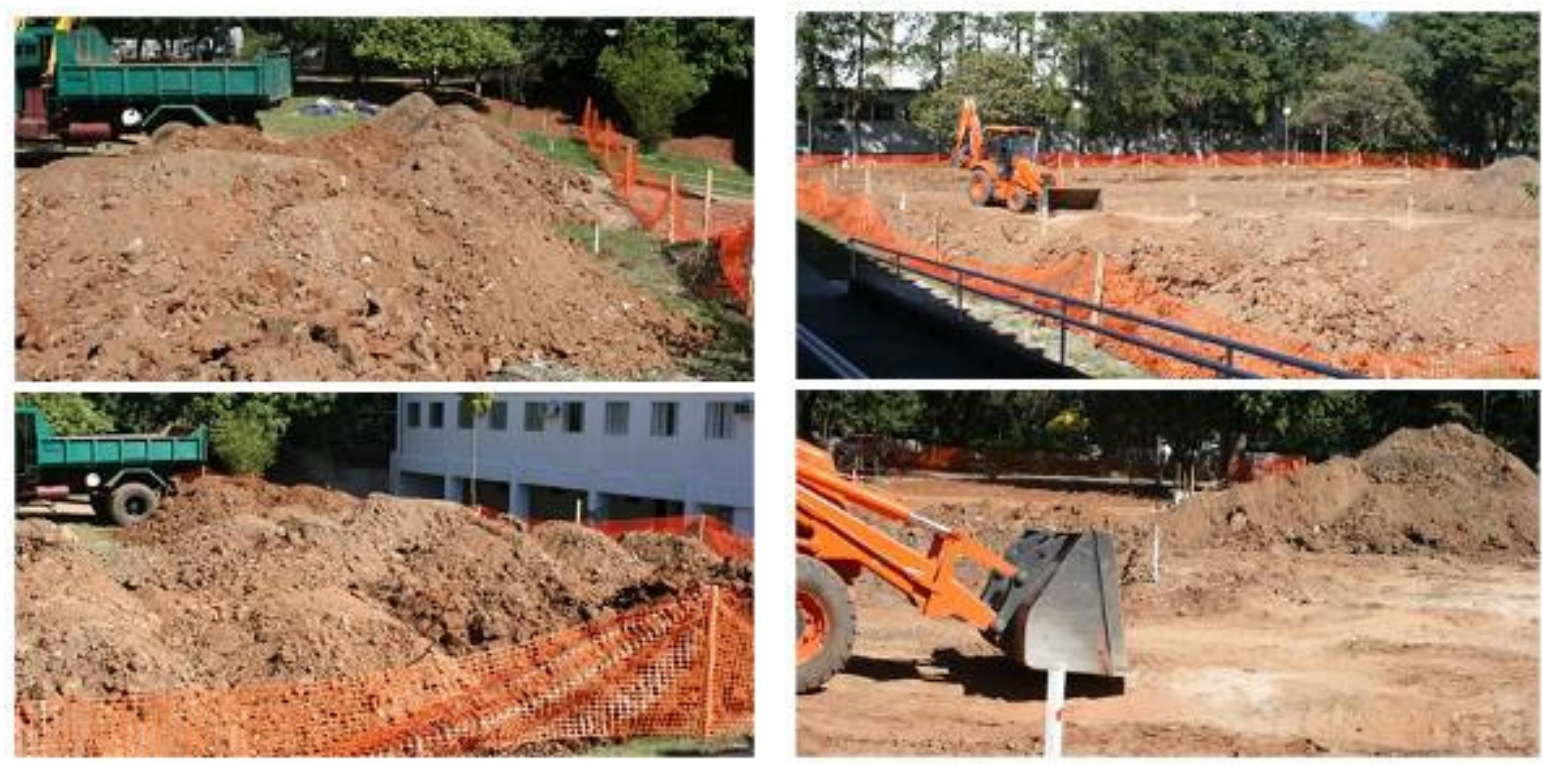

Foto 16 - Seqüência de fotos da preparação do aterro 

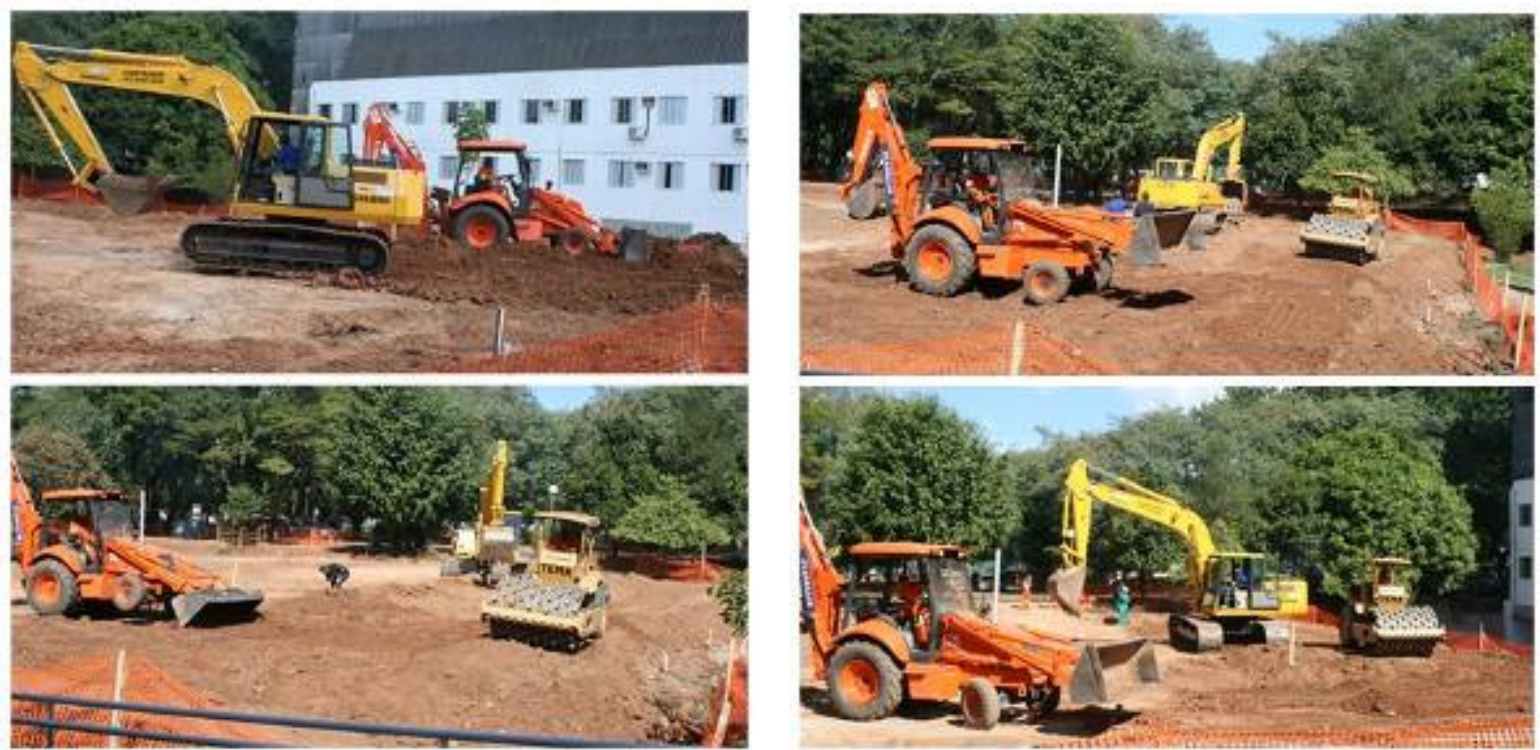

Foto 17 - Seqüência de fotos compactação do aterro (área B)

\section{- Compactação}

Como o resultado das sondagens iniciais indicava um subleito de baixa capacidade de suporte $(\mathrm{CBR}=8,0 \%)$, após a abertura da caixa foi executado o trabalho de compactação do subleito com rolo compactador tipo pé de carneiro.
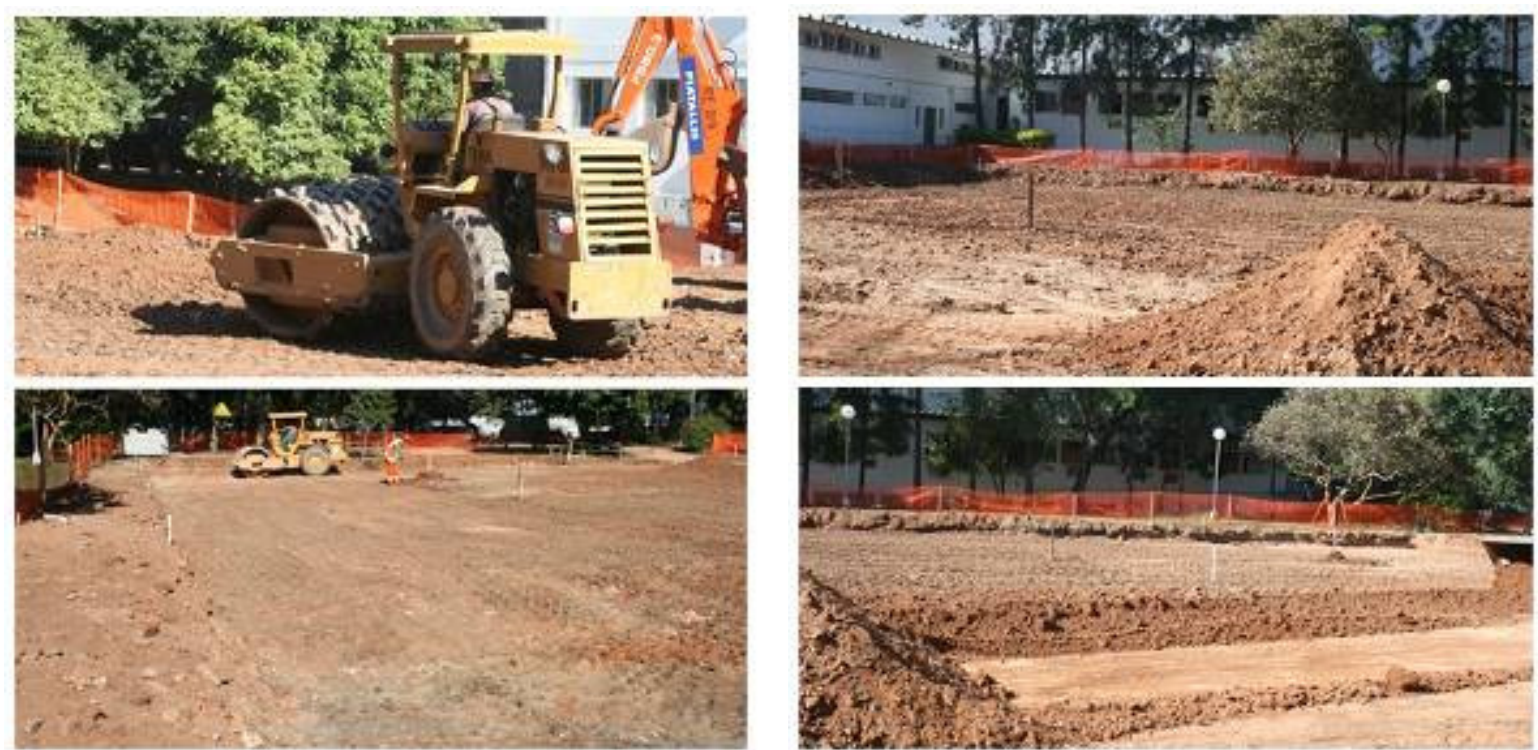

Foto 18 - Compactação do subleito 


\section{- Camada de Reforço e Nivelamento}

Para o local do experimento foi recomendado o reforço de subleito de no mínimo 20 $\mathrm{cm}$ com solo de empréstimo. Portanto a cota de corte foi determinada pela topografia levando-se em consideração o reforço de subleito cujo CBR deveria ser superior a $8,0 \%$.

Muitas dificuldades foram encontradas nesta etapa, pois, não se conseguia achar solo adequado para a substituição. Para obras localizadas dentro de áreas urbanas como esta, aprendeu-se que é de grande importância ter solo para empréstimo já estocado. Por não ter sido tomada esta providência, a obra ficou parada por 12 dias até que se achasse solo de qualidade que fosse aceita pela fiscalização e passasse pelo controle tecnológico. Durante esse tempo diversas viagens de terra foram recusadas por não apresentarem as condições mínimas de compactação.

O solo de reforço aceito foi espalhado por toda a área do estacionamento através de motoniveladora, e compactado com rolo tipo pé de carneiro e rolo liso com energia intermediária de compactação.
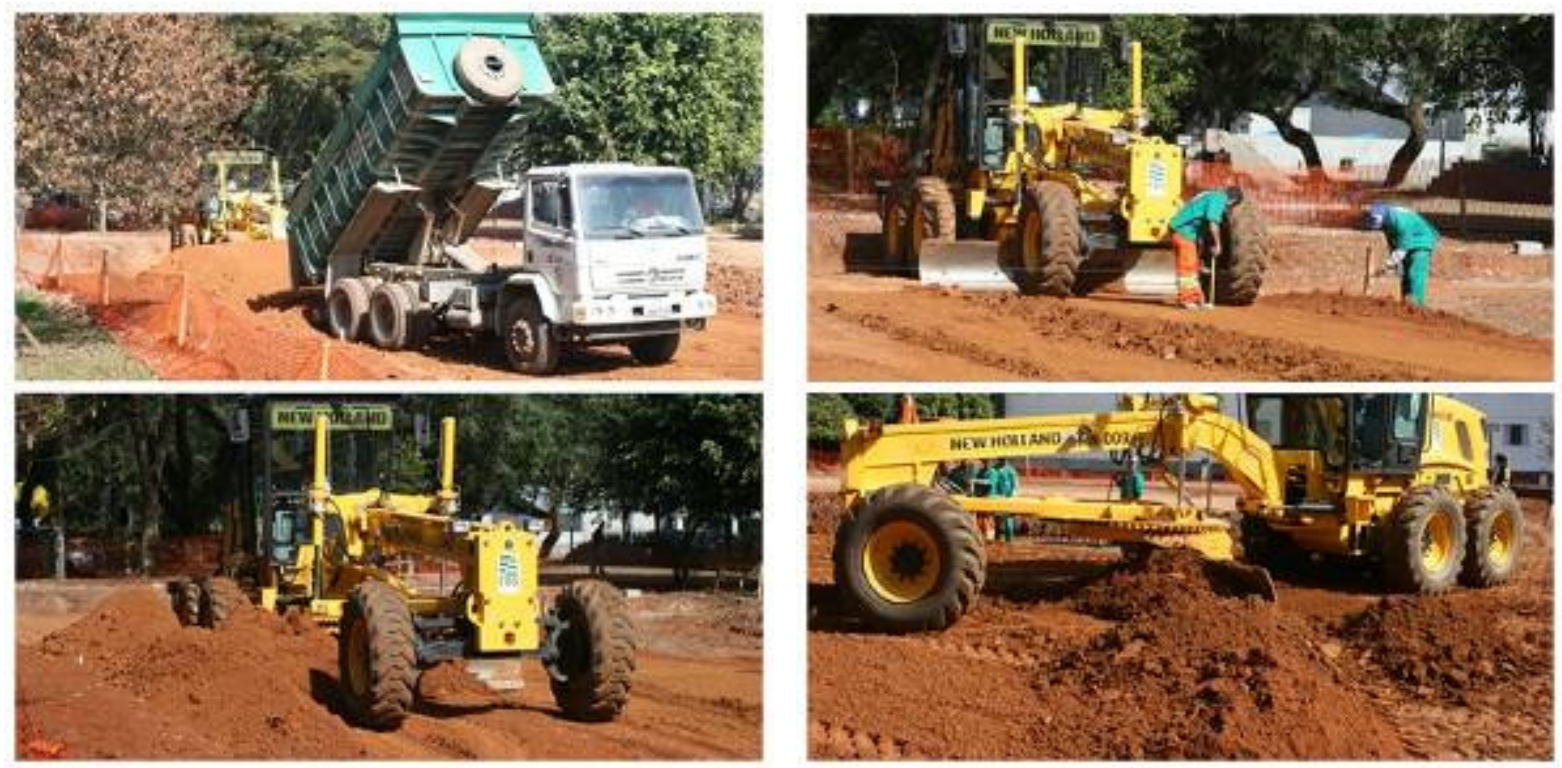

Foto 19 - Espalhamento e nivelamento do solo de reforço 
Não se determinou o CBR do solo de reforço do sub leito visto que foram utilizadas várias jazidas de empréstimo além da principal localizada em Jundiaí a $70 \mathrm{~km}$ de distância. A heterogeneidade pode ser vista na diferença de cor do solo depositado. O CBR foi determinado após a homogeneização dos solos no aterro.

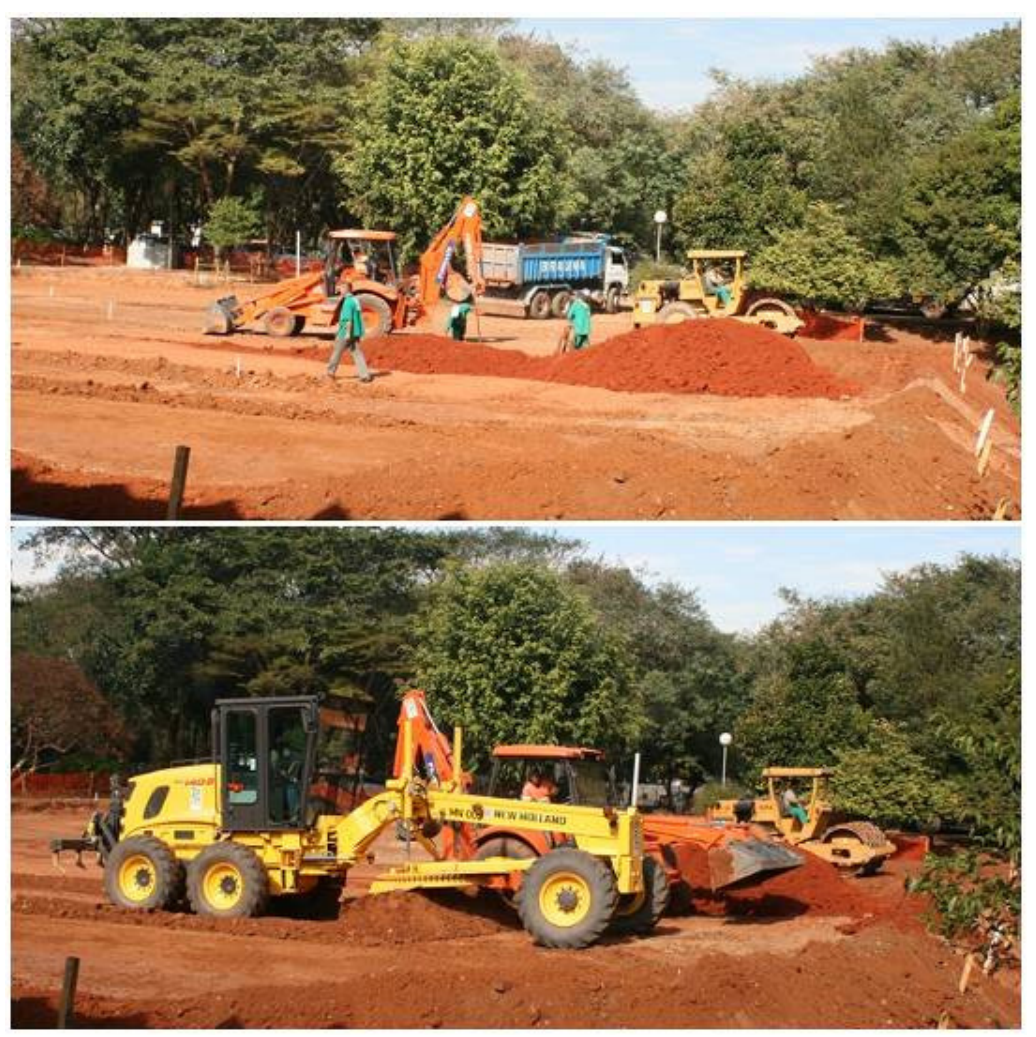

Foto 20 - Solos para reforço do sub leito 


\section{- Rede de Drenagem}

A rede de drenagem em tubos de $300 \mathrm{~mm}$ e $400 \mathrm{~mm}$ tipo ponta e bolsa de concreto, foi assentada sobre berço de brita 3 obedecendo rigorosamente as declividades impostas pelo projeto de drenagem.

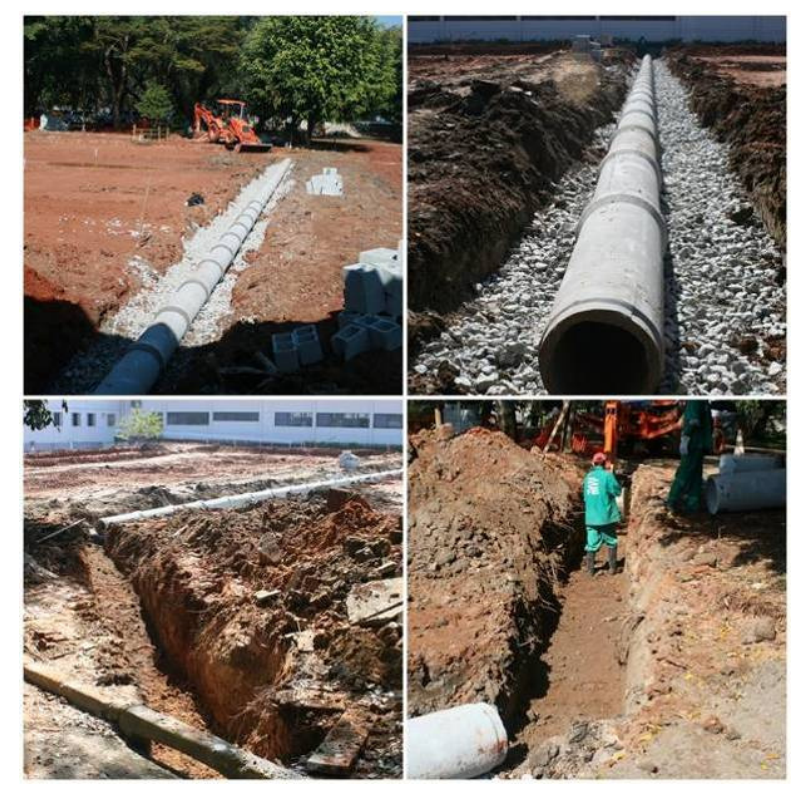

Foto 21 - Instalação da rede de drenagem

- Coleta de material para ensaio de CBR

Optou-se fazer a coleta de material para o ensaio da capacidade de suporte após a homogeneização e compactação (Foto 22 abaixo).

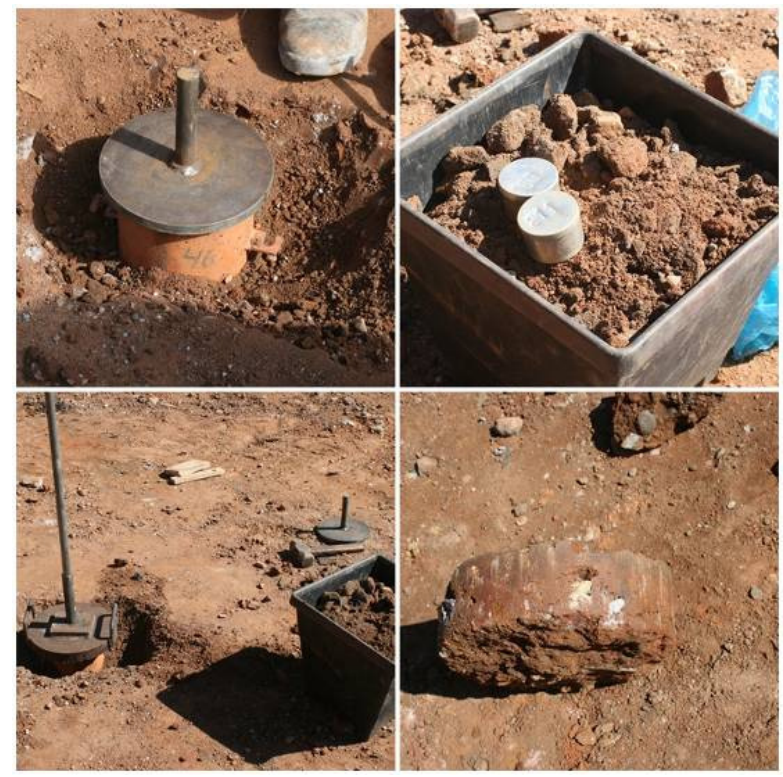

Foto 22 - Coleta de amostras para ensaio de CBR. 


\section{- Geomembrana}

A geomembrana de PEAD e espessura $1 \mathrm{~mm}$ foi assentada diretamente sobre 0 subleito previamente salgado com fina camada de pó de pedra, a seguir espalhou-se a camada de proteção de pó de pedra de $10 \mathrm{~cm}$ em etapas soldando-se a geomembrana em panos sucessivos. (Foto 23 baixo).
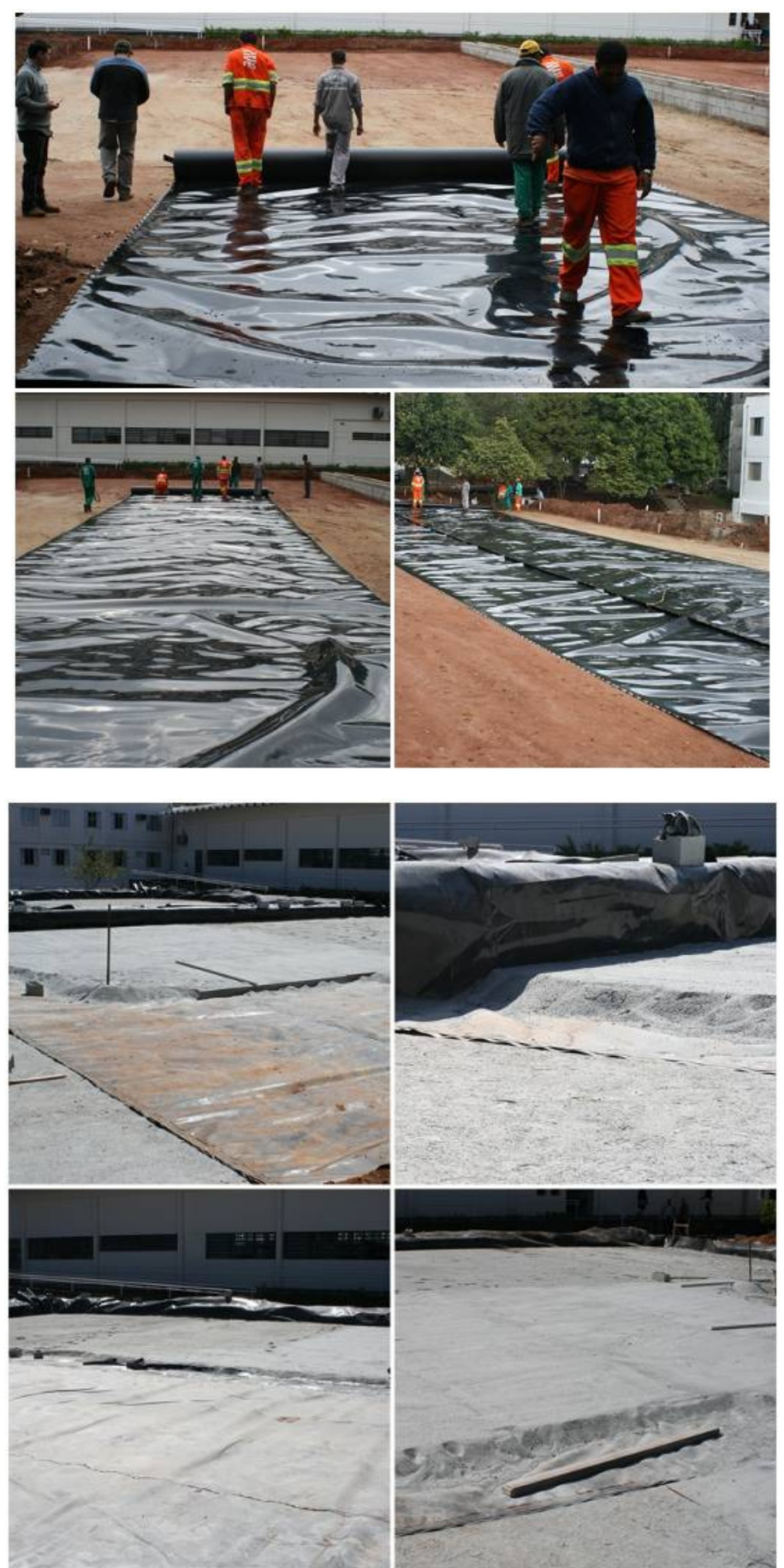

Foto 23 - Assentamento da geomembrana 


\section{- Camada de pedra 3}

Na seqüência, procedeu-se o espalhamento da pedra 3 sendo aplicada em camadas de $10 \mathrm{~cm}$ roladas e compactadas com rolo compactador liso com vibração intermediária. A Área B ficou com espessura de $15 \mathrm{~cm}$ e a Área C, $25 \mathrm{~cm}$. Para a estabilização mecânica espalhou-se pedra 1 e pedrisco que conferiram o travamento final da camada. Todo o espalhamento foi executado manualmente (Foto 24 e 25 abaixo).
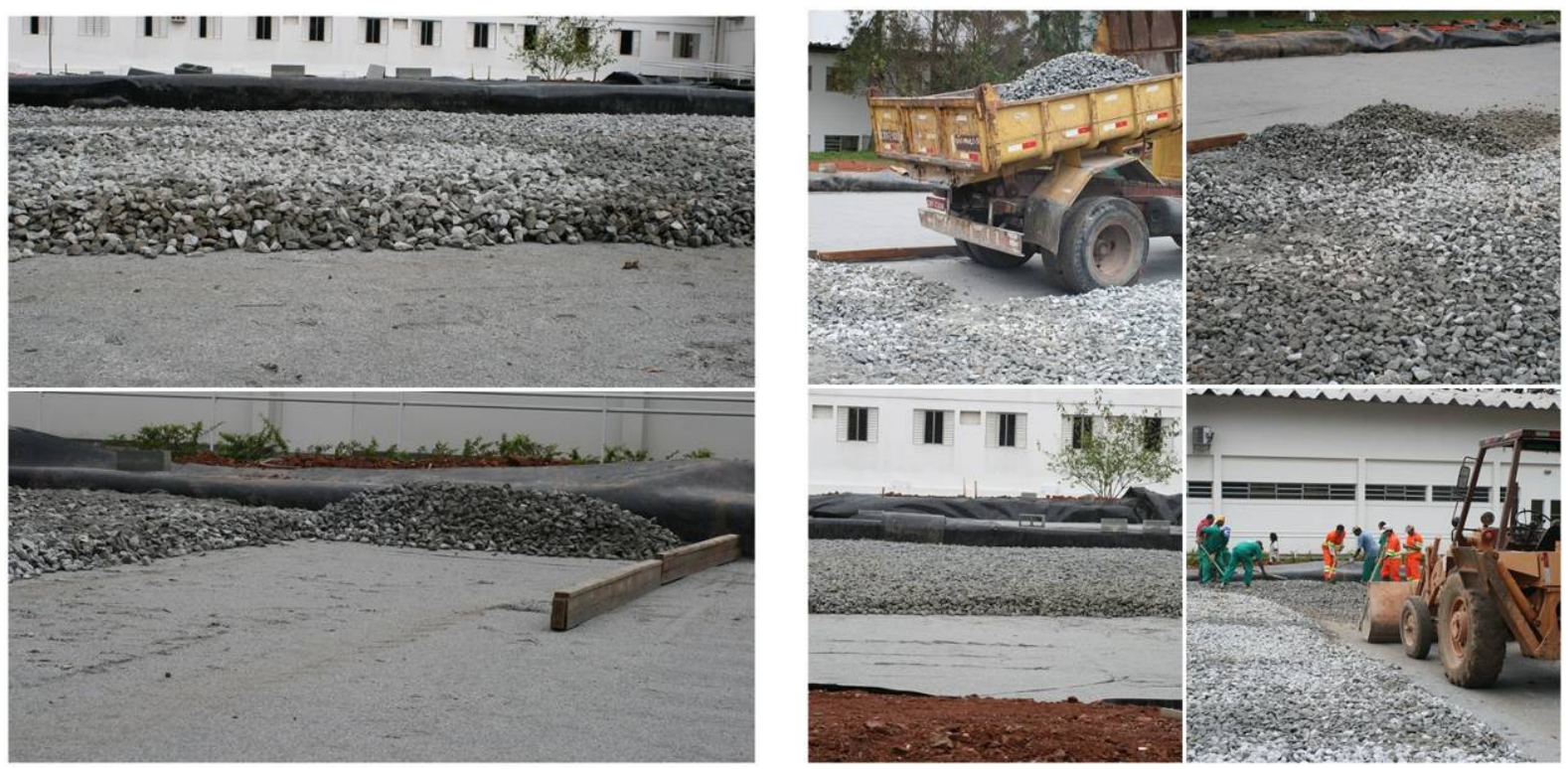

Foto 24 - Espalhamento da pedra 3

- Compactação das camadas
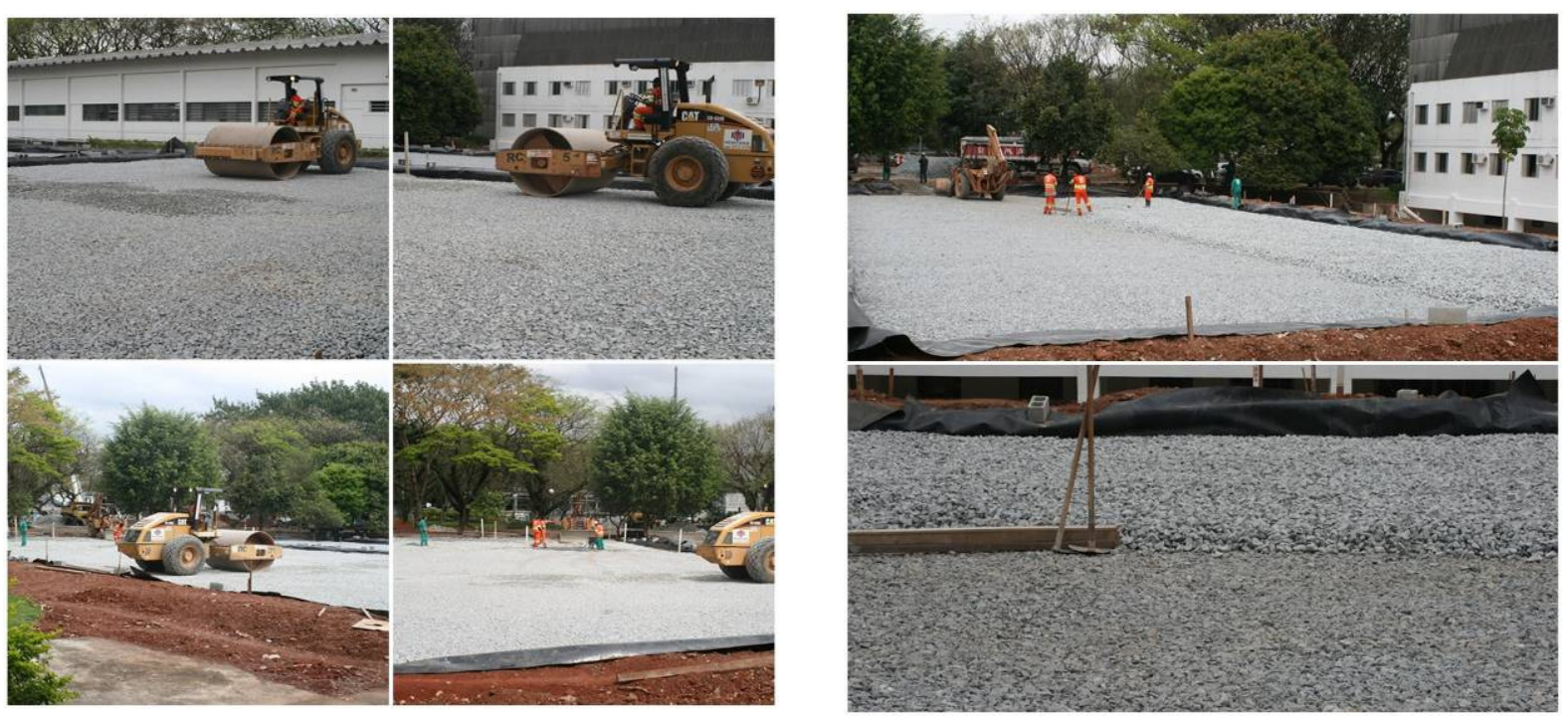

Foto 25 - Compactação das camadas de pedra 3 


\section{- Camada de BGS - Área B}

A BGS foi aplicada na área das PPC de concreto poroso ( área B) sobre a camada anterior de pedra 3. Na interface entre as duas camadas foi realizado salgamento com pedrisco e pedra 1 para fechar o macadame hidráulico. O lançamento da BGS foi feito com retroescavadeira que depositava o material com cuidado, sem lançá-lo de altura maior que 1 metro, após isso, o material era espalhado manualmente. A BGS faixa $B$ do DERSA foi aplicada por ser a única comercializada pela empreiteira porém possui curva granulométrica aberta com pouco teor de finos, menos que $7 \%$ passando pela peneira n. $\stackrel{0}{200}$ (Foto 26 ).
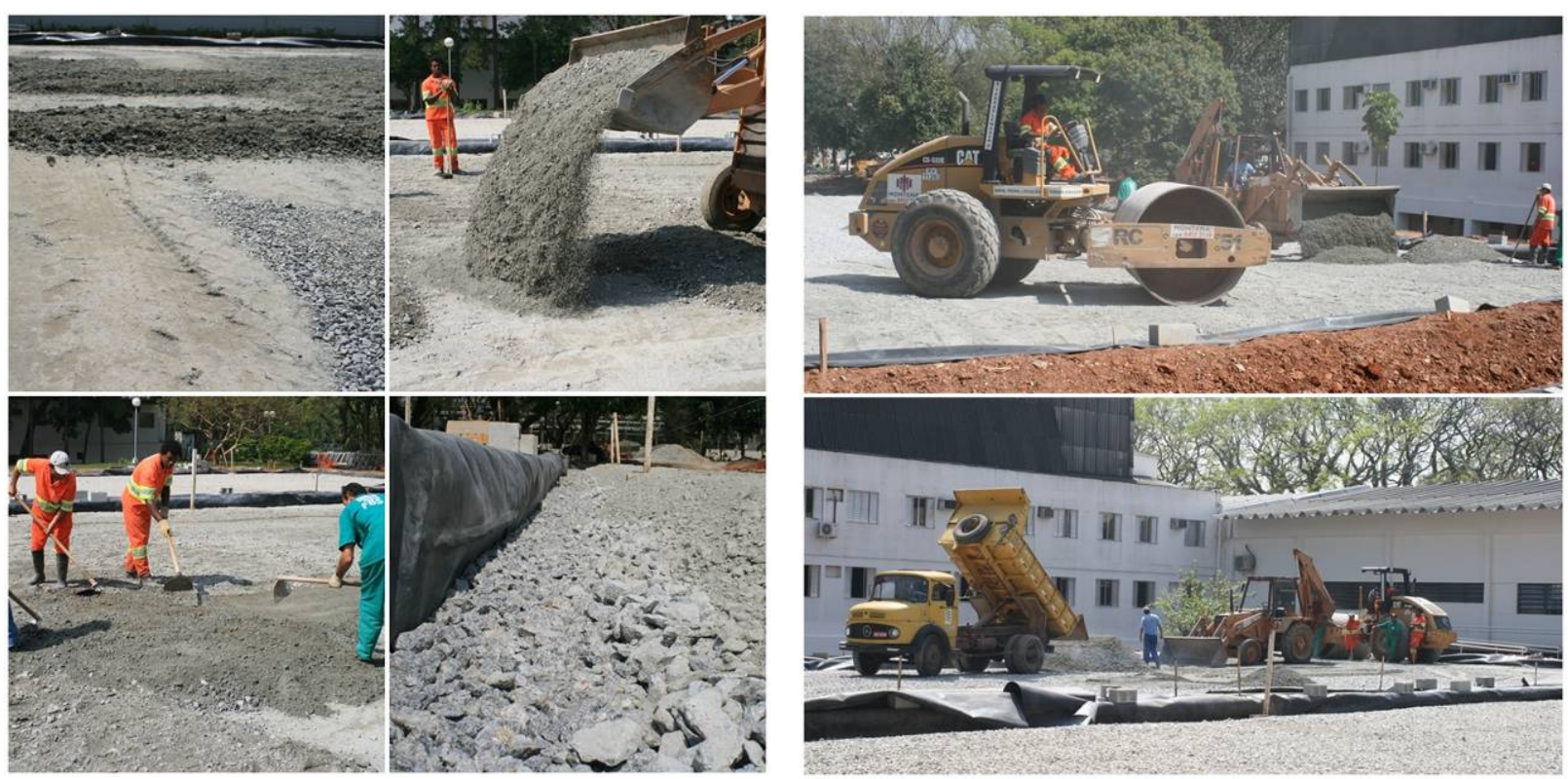

Foto 26 - Lançamento, espalhamento e compactação da BGS 
- Aspecto final da área B (BGS) e da Área C (pedra 3)
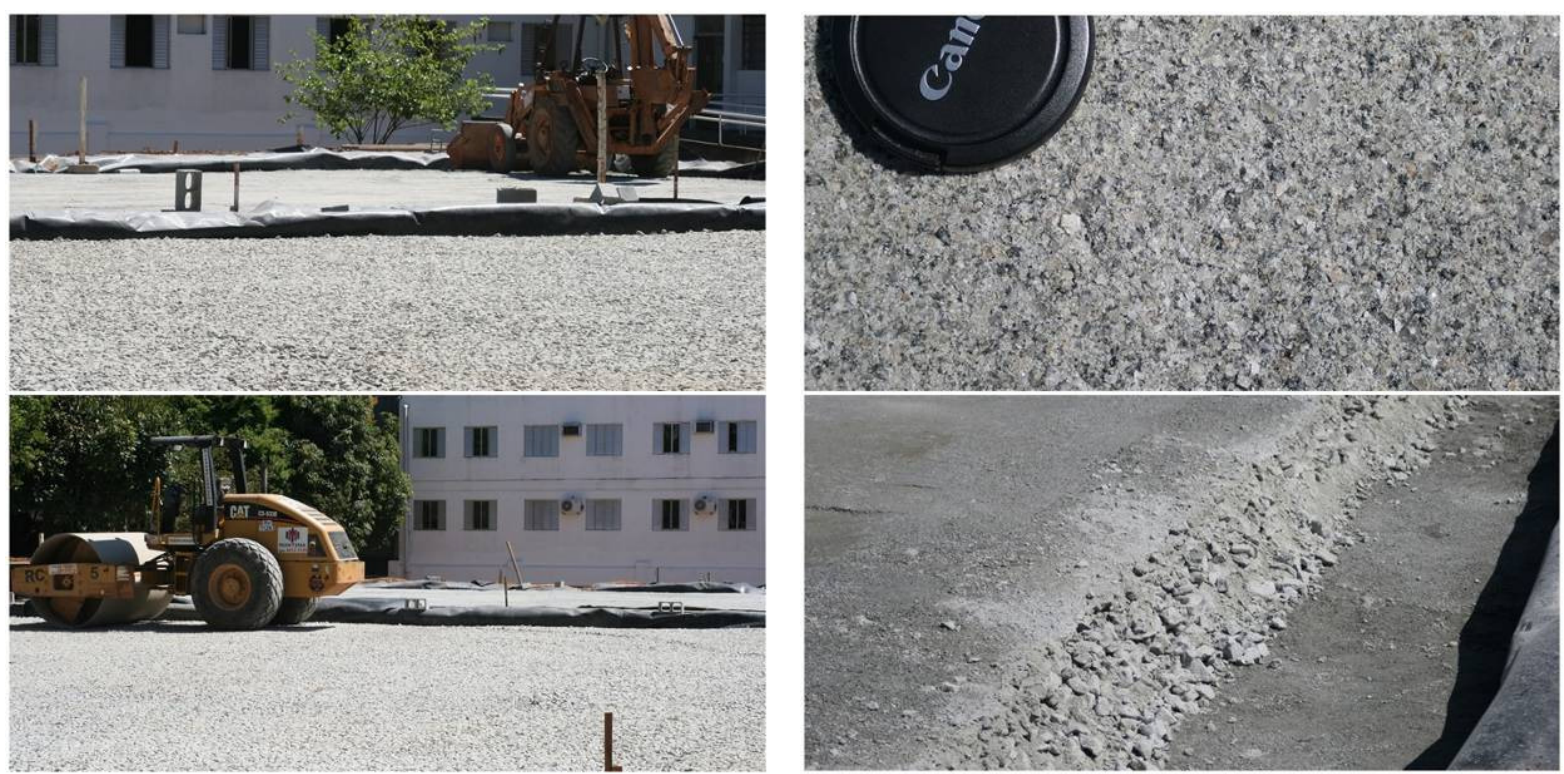

Foto 27 - BGS e pedra 3 após compactação

\section{- Execução das guias e sarjetas}

A cota final do pavimento acabado deve coincidir com a face da sarjeta, assim, através de acompanhamento topográfico determinou-se a cota final de concretagem levando-se em conta a última camada de revestimento em ambos os lados.
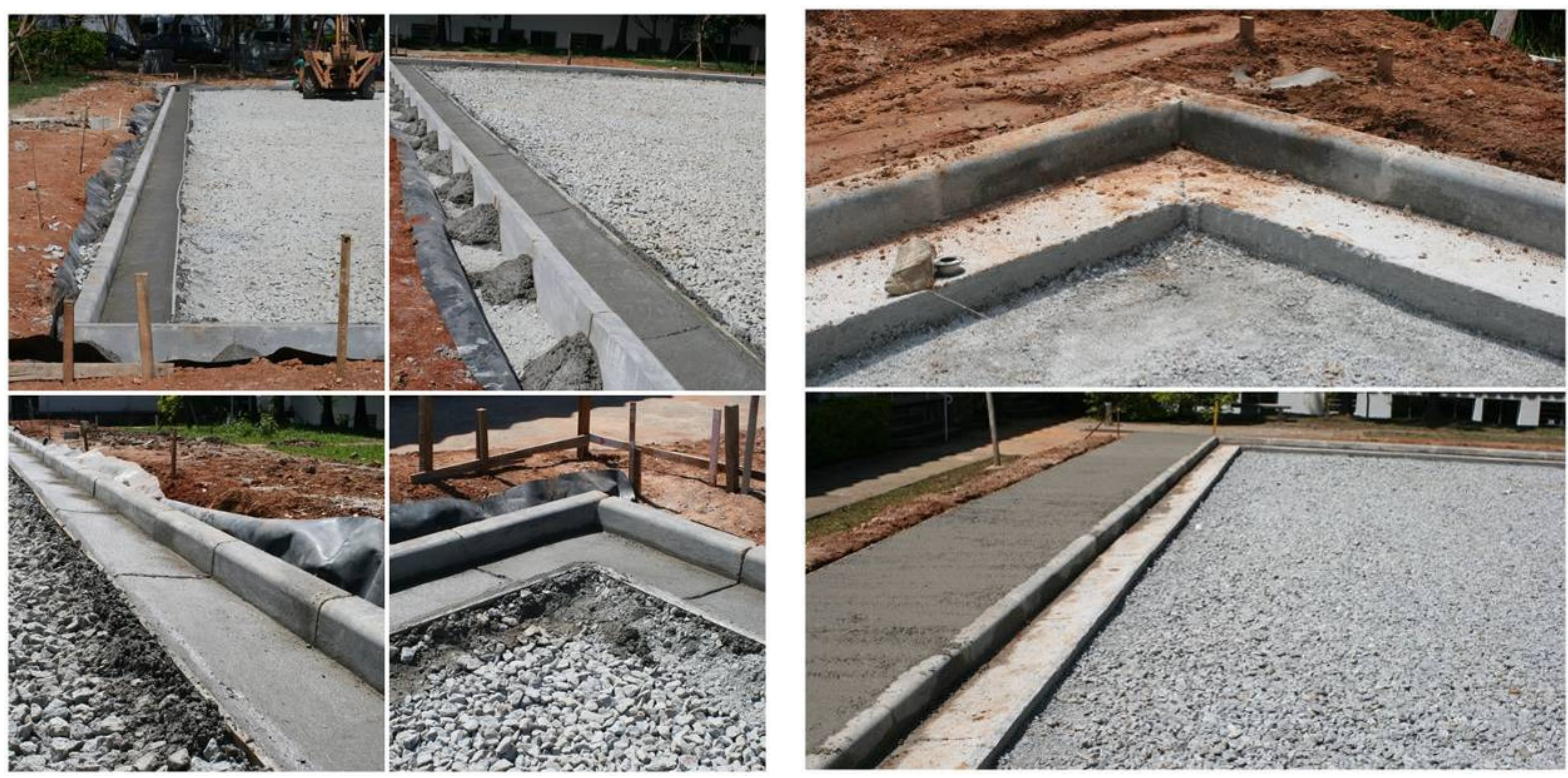

Foto 28 - Execução das guias e sarjetas 


\section{- Execução do Macadame Betuminoso}

$\mathrm{Na}$ área $\mathrm{C}$ preparou-se a camada de $5 \mathrm{~cm}$ de suporte ao revestimento com macadame betuminoso travado estruturalmente com britas de gradação inferiores como pedra 1 e pedrisco que foram compactados com rolo liso vibratório.
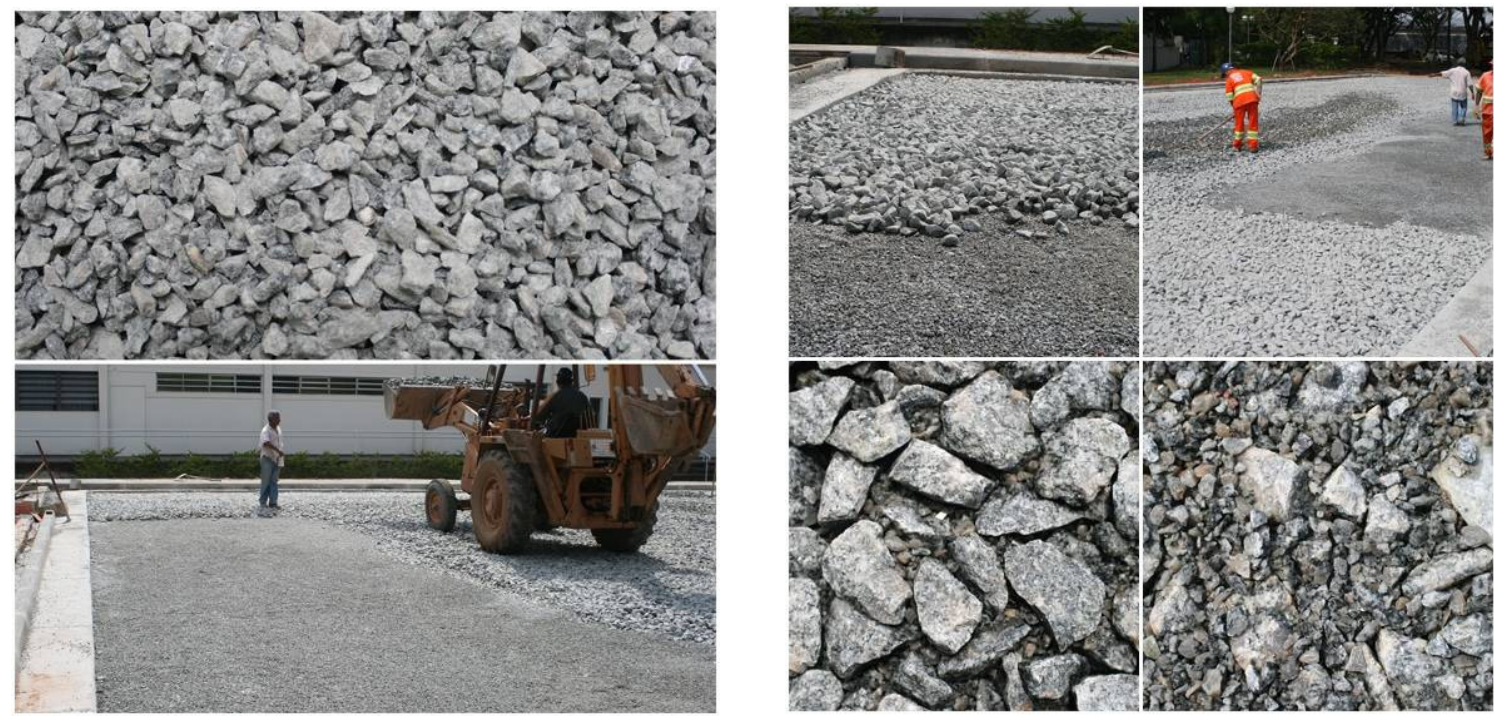

Foto 29 - Execução do macadame betuminoso

\section{- Imprimadura com ligante asfáltico}

A seguir, o material pétreo da última camada, recebeu imprimadura ligante ADP asfalto diluído de petróleo tipo CM-30 na proporção de 0,8 litros $/ \mathrm{m}^{2}$. O ligante asfáltico foi espargido à quente e de maneira rápida de forma a apenas conferir aderência aos grãos sem no entanto diminuir significativamente o teor de vazios.

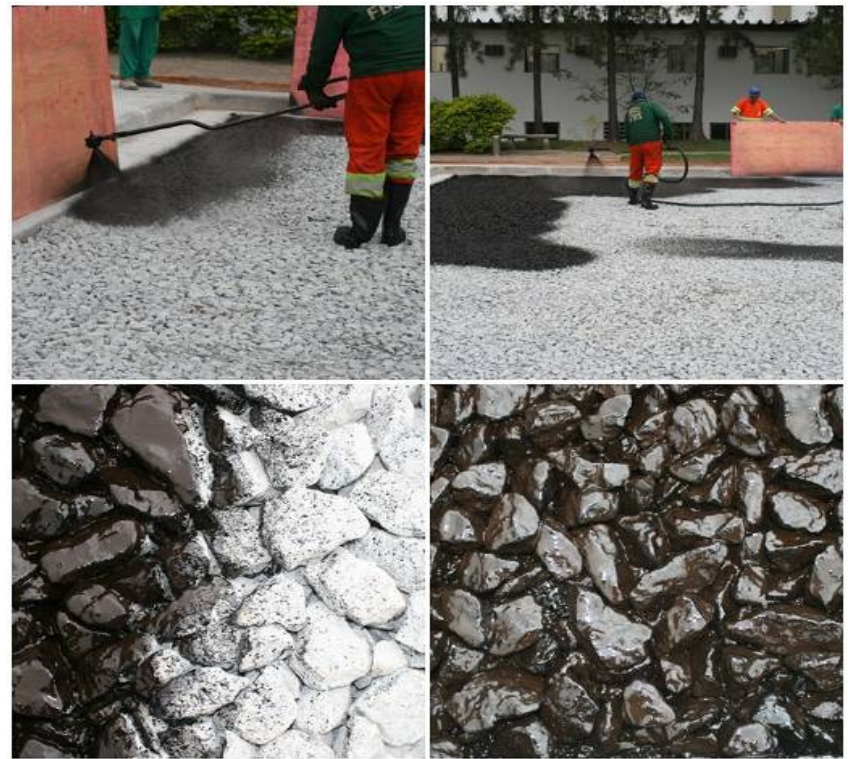

Foto 30 - Imprimadura ligante - macadame betuminoso 


\section{- Camada Porosa de Atrito - CPA}

Como revestimento final, foi executado o concreto asfáltico permeável tipo CPA na área $\mathrm{C}$ do estacionamento. As características da dosagem poderão ser vistas no Anexo D. O índice de permeabilidade alcançado foi de $0,4 \mathrm{~cm} / \mathrm{s}$, em ensaios realizados no CTH. O volume de vazios da mistura foi de $20,1 \%$.

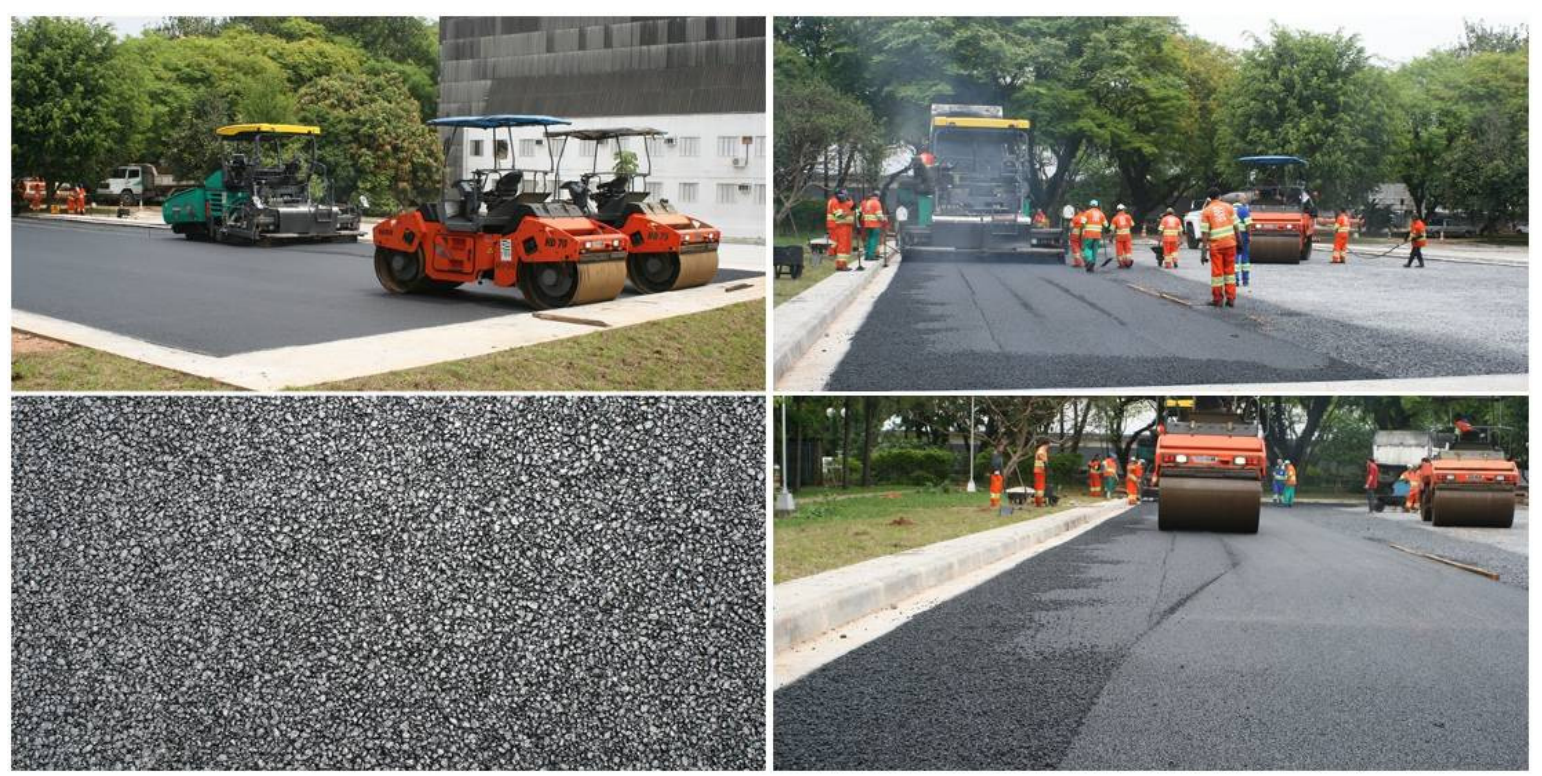

Foto 31 - Execução da camada porosa de atrito - CPA

\section{- PPC porosas}

O revestimento final da área $B$ foi executado com PPCs de concreto poroso, desenvolvidas para o experimento e ensaiadas nos laboratórios da ABCP. Após ensaios o índice de permeabilidade alcançado para essas peças foi de $0,5 \mathrm{~cm} / \mathrm{s}$. A resistência a compressão foi de $25 \mathrm{MPa}$ a 28 dias de idade.

Os blocos intertravados de concreto poroso possuem $6 \mathrm{~cm}$ de altura e foram assentados sobre berço de areia grossa.

Visando impedir o carreamento de areia para dentro das camadas inferiores foi assentada manta geotêxtil de $300 \mathrm{gr} / \mathrm{m}^{2}$ em toda a área B. Eventualmente a manta geotêxtil pode ser dispensada caso se verifique que haja transição de granulometria adequada entre as camadas e esta possa ser executada por materiais que 
proporcionem boa filtrabilidade sem carreamento de finos para as camadas inferiores.

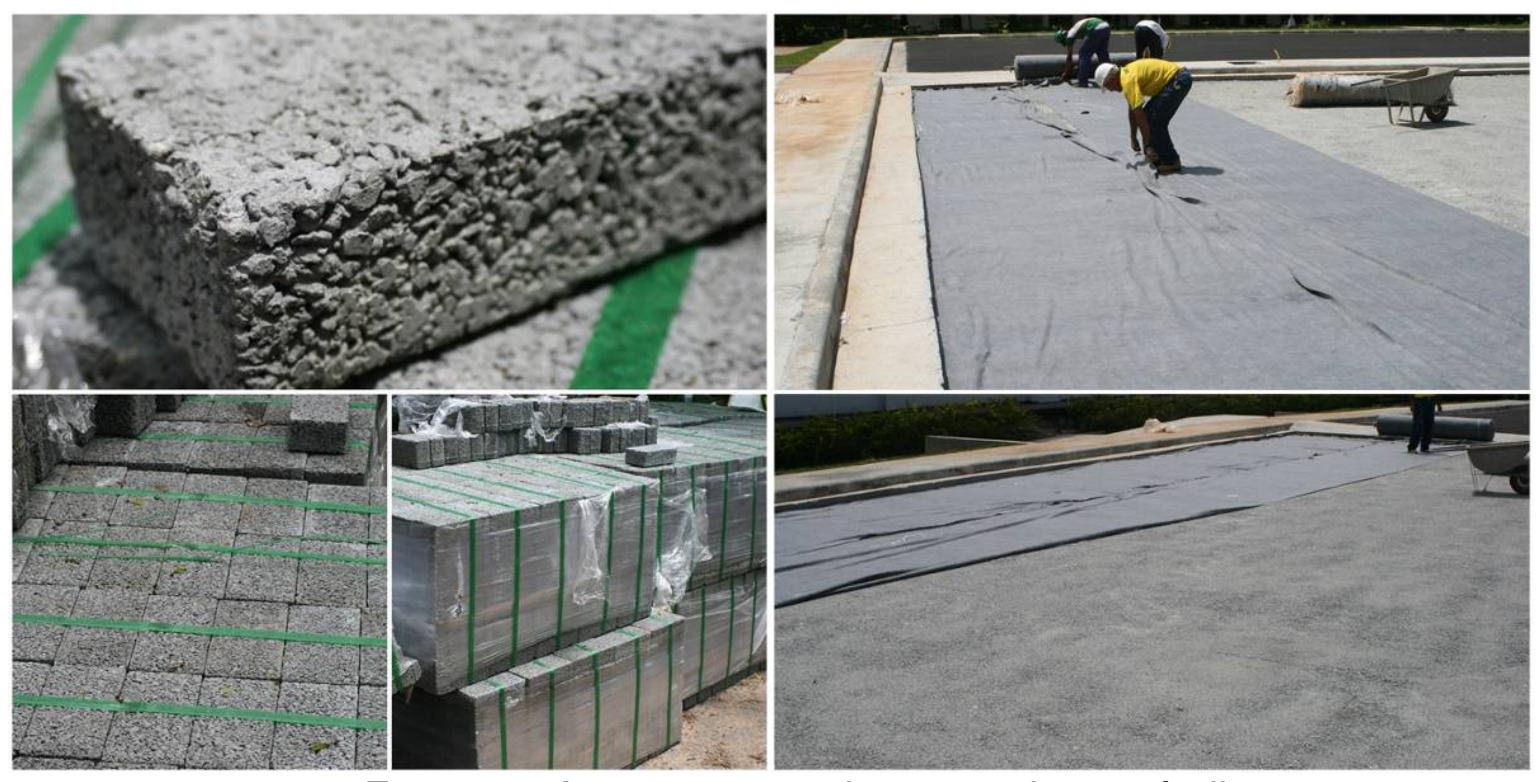

Foto 32 - Assentamento da manta de geotêxtil

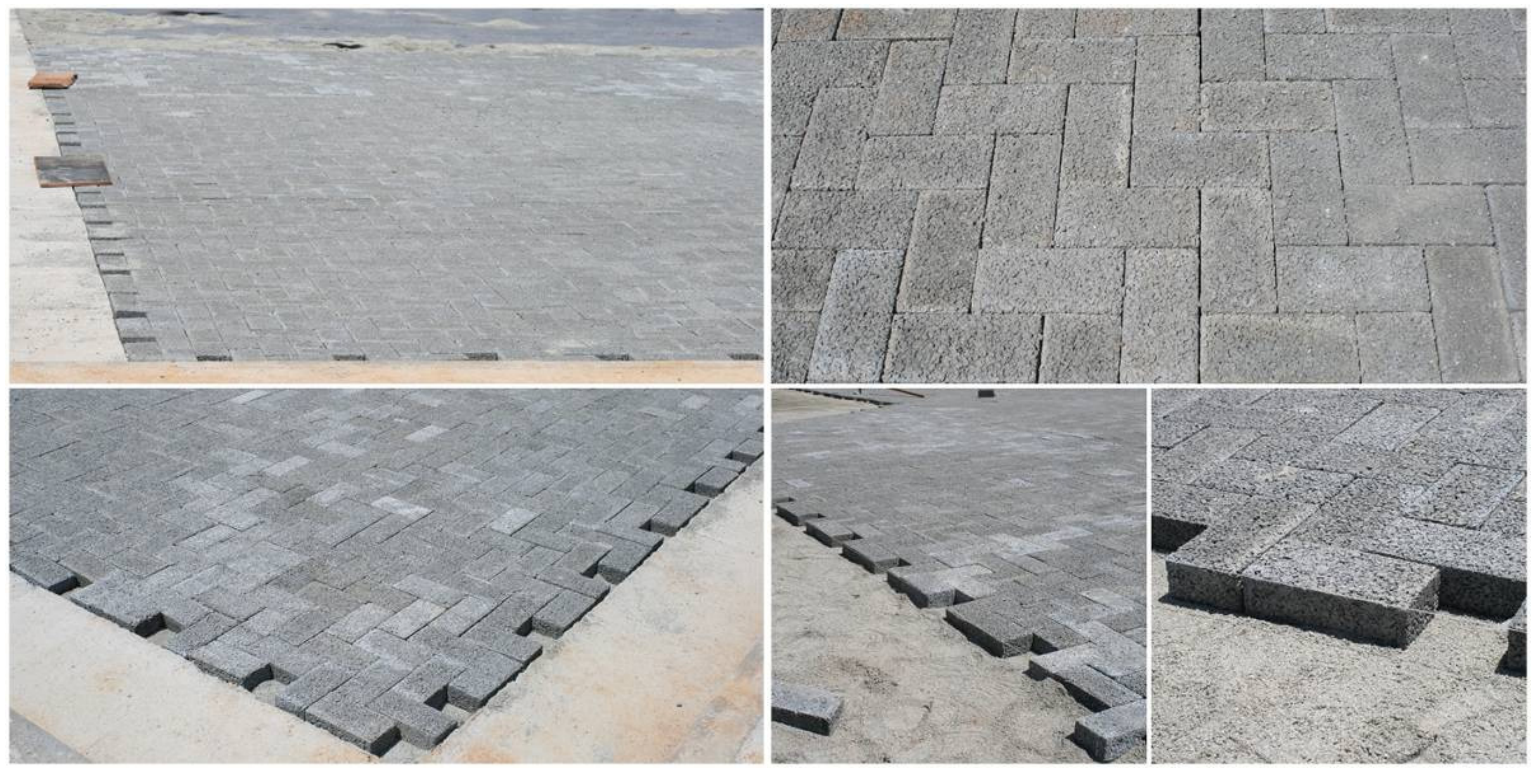

Foto 33 - Peças pré moldadas de concreto poroso - Assentamento 
- Fotos do local antes e depois da execução das obras

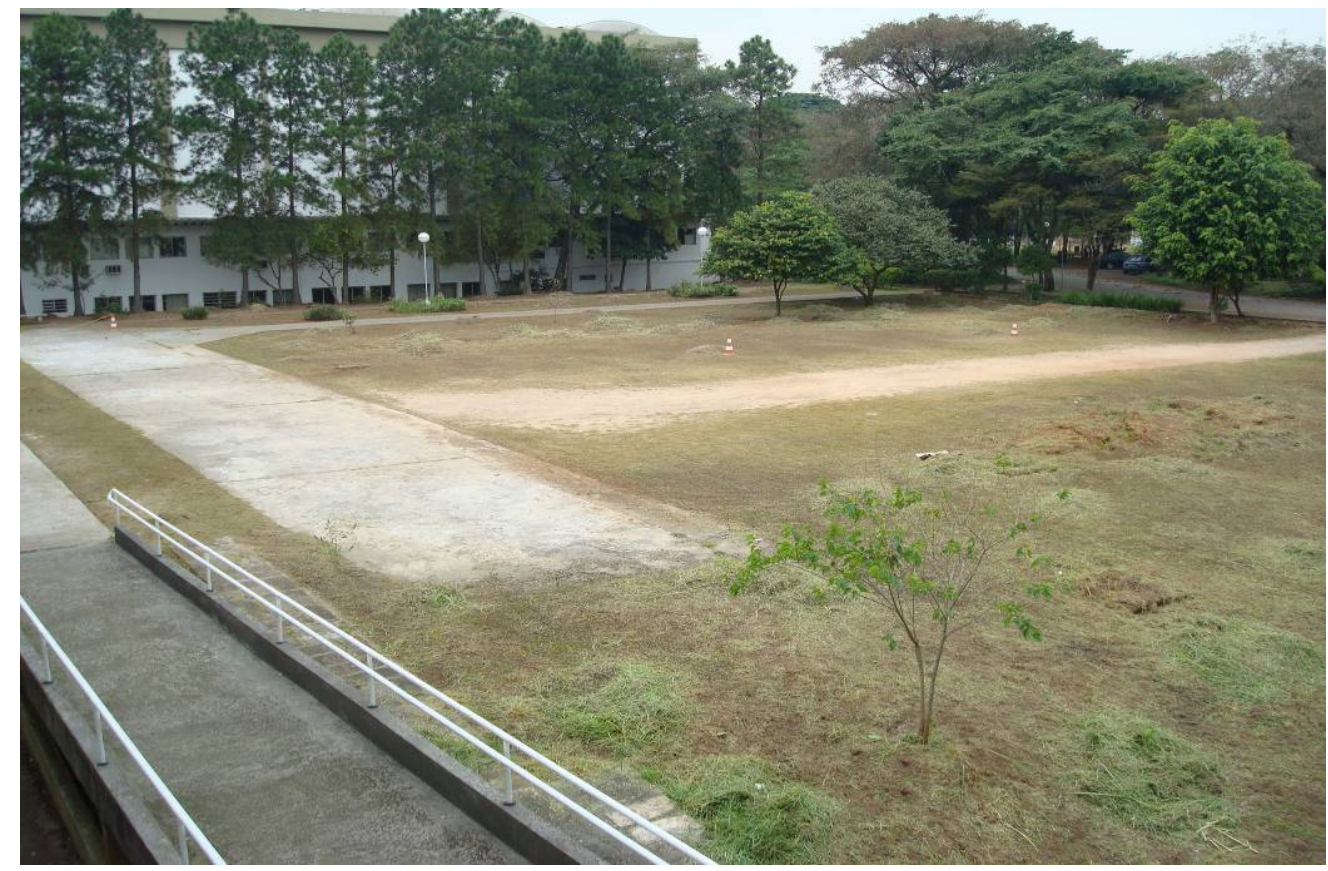

Foto 34 - Antes do início das obras

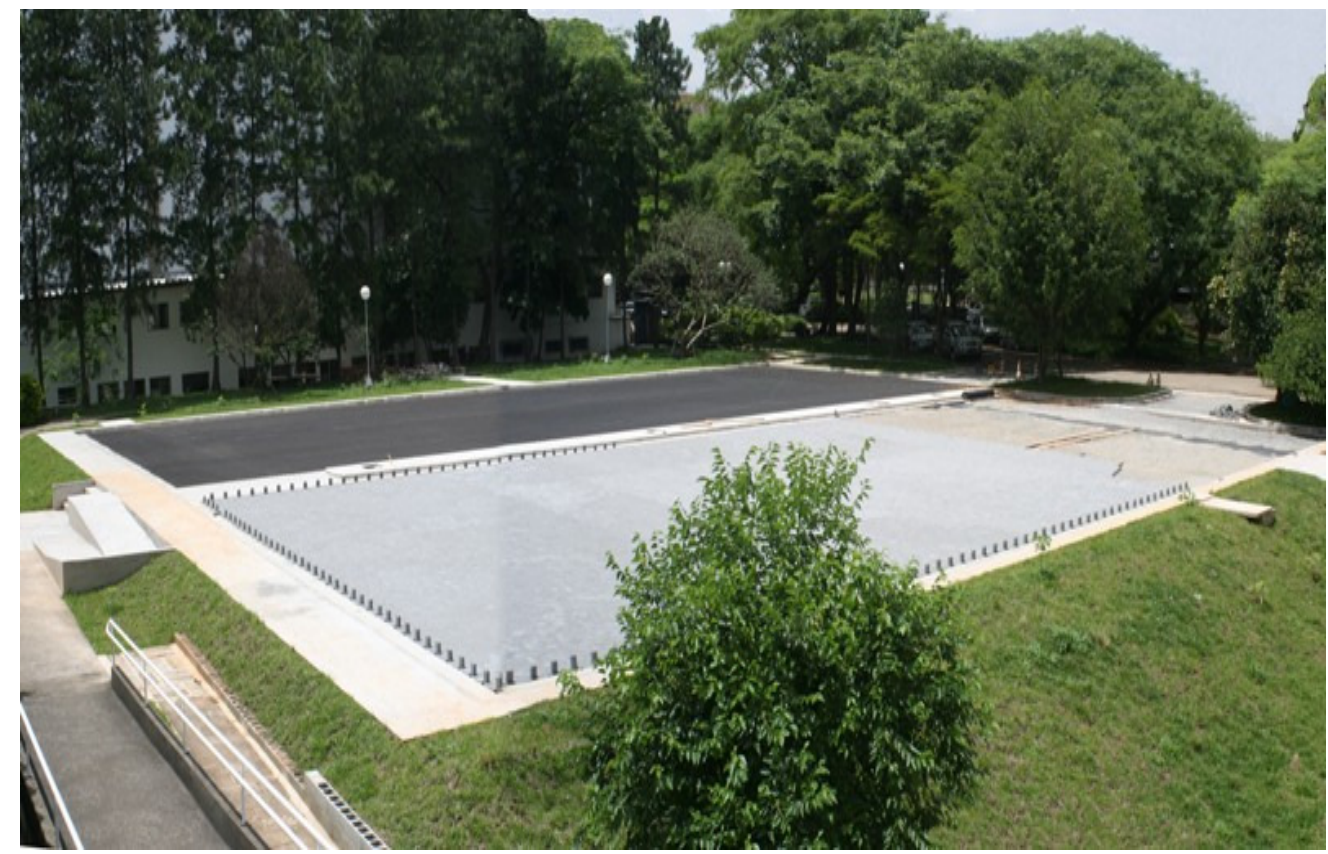

Foto 35 - Obras concluídas 


\section{CONCLUSÕES E RECOMENDAÇÕES}

Pela pesquisa bibliográfica desenvolvida verificou-se que a eficiência do controle de escoamento superficial e conseqüente amortecimento de picos de cheias depende do desempenho do pavimento permeável a ser adotado.

No caso específico do trabalho optou-se, em decorrência das condicionantes locais e objetivando estudos hidrológicos e hidráulicos do dispositivo de retenção, pela estrutura tipo reservatório impermeabilizado e saída da água por exutório.

Em vista da concepção adotada, os aspectos mais importantes do pavimento a ser projetado e construído foram: escolha dos tipos de revestimento drenantes, a capacidade do reservatório sob o ponto de vista hidrológico e hidráulico, a capacidade estrutural do conjunto para suportar cargas do tráfego previsto e impermeabilização do fundo para evitar a infiltração d'água para o subleito.

Com a experiência adquirida durante o período de estudos, elaboração dos projetos e da execução da obra propriamente dita, pode-se alcançar algumas conclusões e fornecer algumas recomendações para estudos futuros ou para facilitar as atividades de projeto e construção conforme descritas a seguir.

\subsection{Conclusões.}

Apresentam-se a seguir, algumas conclusões provenientes do estudo, da elaboração dos projetos e da execução da pista experimental:

1. Não existem critérios sistemáticos de projeto para a utilização desses dispositivos de controle na fonte como são os pavimentos permeáveis.

2. A elaboração de um projeto detalhado e que contemple todas as etapas, abrangendo todos os aspectos e em conjunto com outros projetos complementares mostra ser de fundamental importância para a implementação de pavimentos permeáveis. 
3. Deve-se sempre definir preliminarmente a concepção do reservatório, pois a escolha de sua utilização como dispositivo voltado à infiltração das águas pluviais ou para o armazenamento das mesmas, deve influir diretamente nos cuidados construtivos quanto a escolha de materiais drenantes, como também de assentamento de geomembrana impermeável sobre o subleito.

4. As declividades longitudinais e transversais da superfície do pavimento deverão ser adequadas para de fato controlar o escoamento superficial e garantir a devida infiltração pelo revestimento drenante. Declividades muito baixas, inferiores a 0,35 \% poderão favorecer a formação de poças d'água, enquanto declividades elevadas tenderão a aumentar a velocidade de escoamento superficial o que não é interessante para o tipo de dispositivo em estudo.

5. O reservatório deverá ser dimensionado hidraulicamente em função da precipitação local, considerando-se período de retorno e tempo de concentração adequados, bem como pelas características físicas e granulométricas dos materiais selecionados para a estrutura do pavimento.

6. Há a necessidade de se conhecer a posição do nível do lençol freático, pois este influirá diretamente no funcionamento da estrutura do pavimento.

7. O dimensionamento estrutural do pavimento deverá ser desenvolvido considerando-se a natureza do tráfego, as condições de suporte do subleito, as características dos materiais empregados para as camadas e utilizando procedimentos de cálculo adotados pelos órgãos rodoviários.

8. São diferentes as espessuras das camadas do pavimento necessárias para fins estruturais e armazenamento hidráulico.

9. É preciso cadastro dos dispositivos de drenagem do sistema existente para fins de lançamento final das águas captadas.

10.É de fundamental importância a proteção mecânica contra o puncionamento da geomembrana utilizada para impermeabilizar o fundo do reservatório. 
11. Apesar dos processos construtivos do pavimento permeável serem semelhantes ao de uma estrutura convencional, os procedimentos e controles tecnológicos de dosagem e execução são fundamentais para que de fato os revestimentos aplicados tenham a devida capacidade de drenagem e infiltração.

12. Os dois tipos de materiais utilizados para o revestimento drenante, não são ainda comumente aplicados no meio rodoviário, o que exigirá investimentos em termos de tecnologia e de estudo de processo construtivo, principalmente quanto aos aspectos de desempenho hidráulico.

13. No estudo de valores, o custo dos materiais componentes da área revestida por blocos intertravados de concreto foi ligeiramente maior que os materiais utilizados na área revestida com concreto asfáltico poroso tipo CPA. Durante a execução, o revestimento asfáltico é financeiramente menos caro que o revestimento de blocos de concreto. No entanto, quando houver necessidade de algum tipo de reparo ou manutenção o pavimento asfáltico apresentará maior custo, pois ensejará etapas com equipamentos e mão de obra especializada além de sua execução depender da disponibilidade da usina e equipamentos para sua aplicação. Assim sendo, a reabilitação do pavimento asfáltico será economicamente mais dispendiosa que a reabilitação do pavimento de blocos intertravados. 


\subsection{Recomendações}

Apresentam-se a seguir as principais recomendações para avaliação e monitoramento dos pavimentos permeáveis executados:

1. Quanto ao aspecto estrutural é necessário constatar se a saturação dos materiais não irá diminuir substancialmente a capacidade de suporte e conseqüentemente levar o pavimento à ruína.

2. No tocante ao aspecto hidráulico é interessante se analisar o balanço hídrico do sistema, avaliando a partir da precipitação as taxas de escoamento superficial e de infiltração da água pelos dois tipos de revestimentos drenantes testados.

3. Avaliação das condições da superfície para verificação do surgimento de anomalias no pavimento e constatação de indícios de colmatação dos materiais empregados para o revestimento.

4. Avaliação da superfície do pavimento quanto ao surgimento de irregularidade longitudinal e recalques em função de eventual ocorrência do fenômeno de bombeamento e carreamento de finos nas camadas inferiores da estrutura.

5. Desenvolvimento de estudo técnico e econômico visando definir melhor tipo de revestimento não apenas considerando o investimento inicial, como também os custos e serviços de manutenção ao longo do tempo.

6. Execução de sondagem e ensaios geotécnicos para a verificação dos desempenhos mecânicos e hidráulicos dos materiais aplicados.

7. Eventual estudo da qualidade das águas sob o aspecto da poluição difusa. 
8. Que sejam desenvolvidos estudos de desempenho mecânico e hidráulico dos materiais granulares para se definir:

- a melhor relação entre a estabilidade e a permeabilidade. Uma maior quantidade de finos favorece a estabilidade enquanto diminui o índice de vazios, reduzindo significativamente a transmissividade hidráulica do material. Caso se opte pela camada granular com poucos finos é necessário que o material pétreo apresente elevada resistência ao desgaste e à abrasão devido ao contato entre os grãos.

- tendo em vista as condições operacionais do pavimento permeável é interessante conhecer a resistência dos materiais granulares quanto à durabilidade frente aos ciclos sucessivos de molhagem e secagem.

9. Elaboração, adaptação e aperfeiçoamento de especificações de materiais e serviços relativos a execução de pavimentos permeáveis.

10. Verificar a possibilidade de se empregar o CPA com ligante asfáltico convencional para os casos de projetos de pavimentos para estacionamentos e outras áreas onde se predomina volume e magnitudes de cargas de tráfego relativamente baixos 


\section{REFERÊNCIAS BIBLIOGRÁFICAS}

AASHTO - AMERICAN ASSOCIATION OF STATE HIGHWAY AND TRANSPORTATION OFFICIALS, - Guide for Design of Pavement Structure - Vol. 2, Washington 1993.

ABINT - ASSOCIAÇÃO BRASILEIRA DAS INDÚSTRIAS DE NÃO-TECIDOS Tecidos Técnicos, Manual de Não-tecidos, classificação, identificação e aplicações, 1999.

ABNT - ASSOCIAÇÃO BRASILEIRA DE NORMAS TÉCNICAS, Rochas e Solos Terminologia - NBR6502/95

ABNT - ASSOCIAÇÃO BRASILEIRA DE NORMAS TÉCNICAS, Execução de Sondagem a Trado - NBR9603/86

ABNT - ASSOCIAÇÃO BRASILEIRA DE NORMAS TÉCNICAS, Determinação da Resistência à Compressão - NBR9780/87

ABNT - ASSOCIAÇÃO BRASILEIRA DE NORMAS TÉCNICAS, Peças de Concreto para Pavimentação - NBR9781/87

ABNT - ASSOCIAÇÃO BRASILEIRA DE NORMAS TÉCNICAS, Rochas e Solos Simbologia - NBR13441/95

ABRH - ASSOCIAÇÃO BRASILEIRA DE RECURSOS HÍDRICOS, "Drenagem Urbana", Vol. 5, Coleção ABRH, São Paulo - Autorização de reprodução desta fonte bibliográfica aposta em ofício da Secretaria de Vias Públicas $n^{\circ}$. 0029/98/PROJ. de 23/09/98 (1995).

ACIOLI L. A., Estudo Experimental de Pavimentos Permeáveis para Controle do Escoamento Superficial na Fonte, Dissertação de Mestrado, (2005) UFRGS - IPH, 2005. 
ARAÚJO, P.R., TUCCI, C.E.M., GOLDENFUN, J.A. - Avaliação da Eficiência dos Pavimentos Permeáveis na Redução de Escoamento Superficial, RBRH Revista Brasileira de Recursos Hídricos. Volume 5, n.3 Jul/Set 2000. p 21-29.

AZZOUT Y., BARRAUD, S., CRES, F.N., ALFAKIH, E.; Techniques Alternatives en Assainissement Pluvial, Paris: Technique et Documentation 1994- Lavoisier, 372 p.

BAPTISTA, M.: NASCIMENTO, N.: BARRAUD, SYLVIE, Técnicas Compensatórias em Drenagem Urbana, Porto Alegre: ABRH, (2005), 266 p.

BORDEAUX METRÓPOLE, Les Solutions Compensatoires D'assainissement Pluvial - Communaute Urbaine de Bordeaux - (1999), Guide de Realisation.

BURGÉAP, Influence de La Granulométrie de Matériau Filtrant em Épuracion par Infiltration Percolation. França: Agences de l'Eau - Ministère de l'Environnement, (1992), 79p.

CASAGRANDE F. L. Estudo da Influência do Teor de Finos na Condutividade Hidráulica e Deformabilidade Elástica de Britas - Dissertação de Mestrado Escola de Engenharia da Universidade Federal do Rio Grande o Sul, (2003), Porto Alegre.

CAMPANA, N. A., HAERTEL, V., TUCCI, C., Estimativa de Áreas Impermeáveis através de Sensoriamento Remoto, RBE, Caderno de Recursos Hídricos, (1992), vol. 10 n.2 pp 51-59.

CAMPOS, O. S., Análise do Comportamento de Trecho Piloto de Revestimento Poroso com Asfalto Modificado por Polímero. Tese de Doutorado - Escola Politécnica, Universidade de São Paulo, São Paulo, (1998), 178 p.

CAPPIELA K.; BROWN K., Impervious Cover and Land Use in the Chesapeake Bay Watershed, Ellicott City, MD: Center for Watershed Protection (2001). 
CASTRO, L. R., Mezclas Drenantes. In: 13ํㅡㄹ Congreso Ibero-Americano Del Asfalto, São José, Costa Rica 2005.

CEDERGREN, H. R., Drainage of Highway and Airfield Pavements. New York, Wiley, 1974.

CEDERGREN, H. R., Drenagem de Pavimentos de Rodovias e Aeródromos. Rio de Janeiro, LTC, 1980.

CERATTI, J.A., RUWER, P.M., SOMACAL, L., In: CONGRESSO IBERO AMERICANO DEL ASFALTO, Assuncion, 1997. Anais. Assunção, (1997), p.57-64.

CHRISTORY, J. P., PIPIEN, G., SOUDIEU, B., CHAUCHOT, J., The road and the environment - a marriage of convenience: Thick porous pavements, Proceedings of the Fifth International Conference on Concrete Pavement and Rehabilitation, Purdue University, Indiana, (1993), Vol.2, pp. 107-124.

CIRIA, Infiltration drainage - Manual of Good Practice, CIRIA - Construction Industry Research and Information Association - Report 156, (1996).

COLANDINI, VALÉRIE, Effets des Structures Réservoirs à Revêtemen Poreux Sur les Eaux Pluviales - Qualite des Eaux et Devenir des Métux Lourds - LCPC - Central des Ponts et Chaussées_(1999).

DER/SP - DEPARTAMENTO DE ESTRADAS DE RODAGEM DO ESTADO DE SÃO PAULO

Concreto Asfáltico Poroso com Ligante Modificado por Polímero - Camada Porosa de Atrito - DER/SP ET-DE-P00/028, 2006

DER/SP - DEPARTAMENTO DE ESTRADAS DE RODAGEM DO ESTADO DE SÃO PAULO

Pavimento com Peças Pré-Moldadas de Concreto - DER/SP ET-DE-P00/048, 2006 
DNER - DEPARTAMENTO NACIONAL DE ESTRADAS DE RODAGEM, Diretoria de Desenvolvimento Tecnológico - IPR - Divisão de Capacitação Tecnológica, Especificação de Serviços - ES386/99, Rio de Janeiro, 1999.

DNER - DEPARTAMENTO NACIONAL DE ESTRADAS DE RODAGEM Preparação de Amostras para Ensaios de Caracterização, DNER ME 041/94.

DNER - DEPARTAMENTO NACIONAL DE ESTRADAS DE RODAGEM - Análise granulométrica por peneiramento e sedimentação, DNER ME 080/94.

DNER - DEPARTAMENTO NACIONAL DE ESTRADAS DE RODAGEMDeterminação de Limite de Plasticidade, DNER ME 082/94.

DNER - DEPARTAMENTO NACIONAL DE ESTRADAS DE RODAGEMDeterminação do Limite de Liquidez, DNER ME 122/94.

DNER - DEPARTAMENTO NACIONAL DE ESTRADAS DE RODAGEMCompactação Utilizando Amostras não Trabalhadas, DNER ME 129/94.

DNER - DEPARTAMENTO NACIONAL DE ESTRADAS DE RODAGEMDeterminação do Índice de Suporte Califórnia Utilizando Amostras não Trabalhadas, DNER ME 049/94

DONY, A. Liants Bitumes-Polymères. Paris, Laboratoire Central des Ponts et Chaussées_(1991), :

FCTH - FUNDAÇÃO CENTRO TECNOLÓGICO DE HIDRÁULICA, "Diretrizes Básicas para Projetos de Drenagem Urbana no Município de São Paulo", São Paulo (1995).

FCTH - FUNDAÇÃO CENTRO TECNOLÓGICO DE HIDRÁULICA Programa de Capacitação em Drenagem Urbana e manejo Sustentável de Águas Pluviais - 
Gestão de Drenagem Urbana e Inovações Tecnológicas em Micro Drenagem Apostila de Curso Volume II, (2006).

FAURE, B., et. al. Techniques Nouvelles de Couches de Roulement - Lês Enrobés Drainants. Bulletin de Liaison de Laboratoire dês Ponts et Chaussées, n.172, p. 85-99.

FEBESTRAL. Lês Revêtements Drainants. en pavés de béton Disponível em: $<$ http://www. febestral.be >. Acesso em junho de 2009.

FERGUNSON B. K., Porous Pavements - Integrative Studies in Water Management and Land Development, Taylor \& Francis Group CRC Press (2005), $577 p$.

FIELD, RICHARD, MASTERS, H., SINGER, M., Porous Pavement: Research, Development, and Demonstration. Transportation Engineering Journal 108, (1982), 244-258.

GAL, J. C., Evolution de La Perméabilité dês Enrobés Drainants. Revue Générale dês Routes et Aerodromes, n.702, (1992), p. 118-119.

GENZ, F.; TUCCI, C. E. M., Infiltração em Superfícies Urbanas, RBE Caderno de Recursos Hídricos, V.13, n.1 junho (1995), p77-128.

GONÇALVES, F. J. P.; CERATTI, J. E SOMACAL, L., Investigação do desempenho de Misturas Asfálticas Convencionais e Modificadas com Polímeros: Proposição de um Estudo Envolvendo Ensaios Acelerados de Pavimentos com um Simulador Linear de Tráfego In: Simpósio Internacional de Manutenção e Restauração de Pavimentos e Controle Tecnológico, (2000), São Paulo. 
GONÇALVES F. J. P., Estudo do desempenho de misturas asfálticas convencionais e modificadas por polímeros. Exame de qualificação, PPGEC/UFRGS. (2000), 569 p.

HASELBACH, L.M., VALAVALA, S.; MONTES, F., Permeability predictions for sand-clogged Portland cement pervious concrete pavement systems Journal of Environmental Management, Volume 81, n.ำ, pg 42-49 Outubro 2006.

HUBBER, GERALD, Performance Survey on Open-Graded Friction Course Mixes, National Cooperative Highway Research Program Synthesis of Highway Pratice 284, Washington: Transportation Research Board (2000).

HUET, A., DE BOISSOUDY, J., GRAMSAMMER, C., BAUDUIN, A. E SAMANOS, J. - Experiments with Porous Asphalt on the Nantes Fadigue Test Track Transportation Research Record, n0 1265 - pp. 54 - 58 - Transportation Research Board - National Research Council, Washington, 1990.

KUENNEN, T., A New Era for Permeable Pavements, Better Roads in United States (2003), ( www.betterroads.com).

LEFEBVRE, G., Les Enrobes Drainants, Nantes, Association Internationale des Congrés de la Route (1993),.

MALYCZ, R., NUÑEZ, W. P., GEHLING, W. Y. Y., Pavimentos Permeáveis: Uma Alternativa para o Controle do Escoamento Superficial de Águas Pluviais em Vias Urbanas. In: Reunião de pavimentação Urbana, (2003), 12ª . Aracaju.

MERO, F., SALEMI F. A.; MAGNI, N.L.G E PAGNOCCHESHI, B, Análise das Precipitações Intensas na Cidade de São Paulo. Comunicação Técnica. CTH Centro Tecnológico de Hidráulica, São Paulo, n. 7, 98 p., 1979.

MEURER FILHO, E, Estudos de Granulometrias para Concreto Asfálticos Drenantes. Dissertação de Mestrado - Universidade Federal de Santa Catarina, Florianópolis, S.C., (2001). 
MOTTA, J. C. E TUCCI, C. E. M., Simulation of the Urbanization Effect in Flow, Hydrological Sciences Journal, 29, 2, 6/1984. England.

MUSY, A., SOUTTER M., Physique du Sol. Lausanne: Presses Polytechniques et Universitaires Romandes, (1991), 335p.

NEITHALATH, N., WEISS, W.J. AND OLECK, J., Enhanced Porosity Concrete: Electrical Impedance Acoustic Absorption, and Hydraulic Pemeability. Presented at the ACI Fall Convention, (2003), Boston.

NOGAMI, J. S., VILLIBOR, D. F., Pavimentação de Baixo Custo com Solos Lateríticos. Ed. Vilibor. São Paulo (1995), 240 p.

PARIAT, J. C., Permeametre. Bulletin de Liaison de Laboratoire de Ponts et Chauseés, n.179, (1992), p.3-9.

PÉREZ-JIMÉNES, F. E GORDILLO, J., Optimization of Porous Mixes Through the Use of Special Binders - TRR - 1265 - pp. 59-68 (1990).

PMSP - PREFEITURA DO MUNICÍPIO DE SÃO PAULO, Instruções de Projeto de Pavimentação, Portaria 084/2004 - Diário Oficial do Município (2004).

PMSP - PREFEITURA DO MUNICÍPIO DE SÃO PAULO, (1999)- Secretaria de Vias Públicas, Diretrizes de Projeto de Hidráulica e Drenagem Urbana VOL IV Tomo A.

PMSP - PREFEITURA DO MUNICÍPIO DE SÃO PAULO, Especificações de Materiais - Secretaria de Vias Públicas (1992).

PMSP - PREFEITURA DO MUNICÍPIO DE SÃO PAULO, Preparo do Sub-leito do Pavimento PMSP IE-01 - Secretaria de Vias Públicas (1992). 
PMSP - PREFEITURA DO MUNICÍPIO DE SÃO PAULO, Sub-bases e Bases de Macadame Hidráulico PMSP ES-05- Secretaria de Vias Públicas (1992).

PMSP - PREFEITURA DO MUNICÍPIO DE SÃO PAULO, Sub-bases e Bases de Brita Graduada PMSP ES-06-Secretaria de Vias Públicas (1992).

PMSP - PREFEITURA DO MUNICÍPIO DE SÃO PAULO, Camadas de Macadame Betuminoso PMSP ES-07- Secretaria de Vias Públicas (1992).

PMSP - PREFEITURA DO MUNICÍPIO DE SÃO PAULO, Camadas de Prémisturado a Quente PMSP ES-10- Secretaria de Vias Públicas (1992).

PMSP - PREFEITURA DO MUNICÍPIO DE SÃO PAULO, Diretrizes de Projetos de Pavimentação - SIURB - Secretaria de Infraestrutura Urbana e Obras (2002).

PMSP - PREFEITURA DO MUNICÍPIO DE SÃO PAULO, IP-04 - Dimensionamento de pavimentos Flexíveis para tráfego Leve e Médio, SIURB - Secretaria de Infraestrutura Urbana e Obras (2004).

PMSP - PREFEITURA DO MUNICÍPIO DE SÃO PAULO, IP-06 Dimensionamento de Pavimentos Com Blocos Intertravados de Concreto - SIURB - Secretaria de Infraestrutura Urbana e Obras (2004).

PMSP - PREFEITURA DO MUNICÍPIO DE SÃO PAULO, Plano Diretor Estratégico do Município de São Paulo, Artigo 251, Lei n. $13.430 / 02$ - Secretaria do Verde e Meio Ambiente - Projeto de Compensação Ambiental, (2008).

PUGLIERO GONÇALVEZ, F., Estudo do Desempenho de Misturas Asfálticas Convencionais e Modificadas por Polímeros. Exame de qualificação, PPGEC/UFRGS (2000), $569 \mathrm{p}$.

RIMBAULT, G.; ANDRIEU, H.; BERTHIER, E.; JOANNIS, C.; LEGRET, M., Infiltration des Eaux Pluviales à Travers les Surfaces Urbaines - Des 
Revêtements Imperméables aux Structures-Réservoirs In: Bulletin des Laboratoires des Ponts et Chaussées (2002).

RIMBAULT, GEORGES, Bilan de La Chaussée à Structure-Réservoir de la rue de la Classerie à Reze - Dix ans Après as Construction - LCPC - Laboratorie Central dês Points et Chaussés (2000).

SALATHÉ, J. E. et. al., Pesquisa IPR sobre Asfaltos Modificados por Polímeros. In: ENCONTRO DO ASFALTO, 11., Rio de Janeiro, 1990. Anais. Rio de Janeiro, IBP, 1990. p. 155-208..

SCARATI MARTINS, J. R. Programa de Capacitação em Drenagem Urbana e manejo Sustentável de Águas Pluviais - Gestão de Drenagem Urbana e Inovações Tecnológicas em Micro Drenagem - Apostila de Curso Volume II, (2006). FCTH - FUNDAÇÃO CENTRO TECNOLÓGICO DE HIDRÁULICA

SETRA, Service D'études Techiniques Des Routes Etautoroutes. Coldrain e-Avis Technique, Comission Générale dês Avis Techniques Routes, Bagneaux, (1990),.

SHACKEL, B., Design and Construction of Interlocking Concrete Block Pavements. Londres e Nova lorque, Elsiever Science Publishers, (1990).

SCHUELER, T., Controlling Urban Runoff: A pratical Manual for Planning and Designing Urban BMP's. (1987),

SMITH, D. R., A Road to the Future Tracing The History of Concrete Pavers, Landscape design, September (1999), p 19-21.

REVISTA ENGENHARIA, Geomembranas: Impermeabilização e Proteção Ambiental - 2ª parte (instalação e controle) edição 547ª (2001).

ROLLINGS, R.S., ROLLINGS M.P., Aplications for Concrete Paving Block in the United States Market, Palm Beach Gardens, Florida, UNI-GROUP-USA (1992). 
THELEN, E.; HOWE, L.F., Porous Pavement, Philadelphia, Franklin Institute Press (1978).

TUCCI, C. E. M., Hidrologia, Ciência e Aplicação, 2ª Edição - Porto alegre: ED. Universidade/UFRGS: ABRH, (2000).

URBONAS, B.; STAHRE, P., Stormwater Best Management Practices and Detetion, Prentice Hall, Englewood Cliffs, New Jersey, (1993), 450p.

VERHAEGHE, F. C. et. al. Properties of Polimer and Fibre Modfied Porous Asphalt Mixes. In: CONFERENCE ON ASPHALT PAVEMENTS FOR SOUTHERN AFRICA, 6., p. 262-280.

VILLANUEVA, A., TUCCI, C. E. M., Hidrologia Urbana no IPH: Pesquisa e aplicação. Seminário Internacional sobre Manejo del Agua Pluvial Urbana, (1997), p154-162.

WALESH, S. G., Urban Surface Water Management - Edition: illustrated Publicado por Wiley-IEEE, (1989), $518 \mathrm{p}$.

WORLD ONU URBANIZATION PROSPECTS - The 2006 Revision Population Database, 2007.

WORLD ONU URBANIZATION PROSPECTS - The 2005 Revision, 2006. 
8. ANEXOS

8.1. ANEXO A - Termo de Compromisso Ambiental 
TERMO DE COMPROMISSO AMBIENTAL

Processo n. $.^{\circ} 2009-0.080 .683-0$

TCA n. 081/2009

No Departamento de Parques e Áreas Verdes, da Secretaria Municipal do Verde e do Meio Ambiente, SVMA, da Prefeitura do Município de São Paulo, órgão integrante do Sistema Nacional do Meio Ambiente - SISNAMA, de um lado, a Municipalidade de São Paulo, representada pelo SECRETÁRIO MUNICIPAL DO VERDE E DO MEIO AMBIENTE, sito à Rua Paraíso, n. ${ }^{\circ} 387,7^{\circ}$ andar - Paraíso - CNPJ 74.118.514/0004-25, doravante denominado simplesmente SVMA, e de outro, a SECRETARIA MUNICIPAL DE INFRA-ESTRUTURA URBANA E OBRAS, CNPJ n 46.392.171/0006-19, situada à Av. São João, $n^{\circ} 473$, Centro, nesta capital, neste ato representada pelo Secretário Adjunto da Secretaria Municipal de Infra-Estrutura Urbana e Obras, Sr. MARCOS RODRIGUES PENIDO, doravante denominada simplesmente SIURB, à vista dos elementos que instruem o presente, em especial o despacho autorizatório publicado em 07/05/2009, tendo entre si acordado o quanto segue, em decorrência de manejo de vegetação para implantação da Pesquisa para o Desenvolvimento de Pavimentos Permeáveis no Centro Tecnológico de Hidráulica da Universidade de São Paulo - USP, localizada na Av. Prof. Lucio Martins Rodrigues, 120, Cidade Universitária, Săo Paulo, São Paulo, fundamentado no disposto no artigo 251 da Lei $13.430 / 02$ e Decreto $n^{\circ}$ 47.145/06, firmam o presente Termo de Compromisso Ambiental, consoante as cláusulas que seguem:

\section{CLÁUSULA PRIMEIRA - DO COMPROMISSO E DA COMPENSAÇĀO}

1.1. SIURB se compromete a atender os seguintes itens:

- Transplantar 2 (duas) árvores para dentro do terreno.

- Preservar 43 (quarenta e três) árvores no local.

- Plantar 14 (catorze) mudas de espécies nativas do Estado de São Paulo, padrão DEPAVE, com DAP $5,0 \mathrm{~cm}$ e respectivos tutores, no local.

1.2. SIURB deverá assegurar a preservação de todos os exemplares arbóreos existentes no local, indicados e eventualmente não indicados na planta, cuja supressăo não tenha sido expressamente autorizada. 


\section{CLÁUSULA SEGUNDA - DO TRANSPLANTE}

2.1. REMOVER POR TRANSPLANTE 2. (duas) árvores para dentro do terreno.

2.2. Os transplantes deverão ser realizados com o máximo rigor técnico, devendo ser acompanhados por um profissional devidamente habilitado, com o recolhimento da devida Anotação de Responsabilidade Técnica - ART junto ao órgão de fiscalização do exercício profissional competente, podendo ser suspensos a qualquer momento, caso não estejam sendo realizados a contento, conforme normas técnicas para transplante em anexo, que integra o presente.

2.3. A SIURB deverá comunicar por carta protocolada, acompanhada dos documentos comprovantes do técnico responsável especificados acima, o início dos procedimentos indicados para o devido acompanhamento por técnicos do DPAA/DEPAVE, sendo que todos os procedimentos deverão ser documentados fotograficamente.

2.4. Caso o(s) espécime(s) transplantado(s) não resista(m) ao transplantè, deverá(ão) ser compensado(s) com o plantio no mesmo local de muda(s) de espécie a ser definida por DPAA/DEPAVE com DAP (diâmetro a altura do peito) de $0,07 \mathrm{~m}$ e a entrega de mudas de exemplares arbóreos e de protetores, tendo como base o DAP (diâmetro a altura do peito), da espécie a ser definida por DPAA/DEPAVE, no local e nas condiçōes estabelecidas no anexo "Normas e especificações para o recebimento de mudas de árvores", assim correspondentes:

$$
\begin{array}{ll}
\text { DAP de } 05 \text { a } 10 \mathrm{~cm} & 12 \text { (doze) mudas } \\
\text { DAP de } 11 \text { a } 30 \mathrm{~cm} & 32 \text { (trinta e duas) mudas } \\
\text { DAP de } 31 \text { a } 60 \mathrm{~cm} & 72 \text { (setenta e duas) mudas } \\
\text { DAP de } 61 \text { a } 90 \mathrm{~cm} & 120 \text { (cento e vinte) mudas }
\end{array}
$$

2.5. Se ficar constatado que o espécime transplantado não resistiu por descumprimento das normas técnicas para transplante, além do cumprimento do item 2.4 ficará o responsável técnico pelo empreendimento sujeito às penalidades previstas em lei.

2.6. SIURB assumirá integral responsabilidade pela remoção, plantio e preservação previstos neste termo, responsabilizando-se pelos danos decorrentes de sua realizaçăo.

2.7. O prazo poderá ser prorrogado, por iguais periodos, mediante pedido justificado, antes de findo o prazo inicial.

2.8. Todos os procedimentos do item 2.1 deverão ser documentados fotograficamente. 


\section{CLÁUSULA TERCEIRA - DA PRESERVAÇÃO}

3.1. PRESERVAR 43 (quarenta e três) árvores no local.

3.2. A perda de qualquer exemplar preservado deverá ser compensada com o plantio no mesmo local de uma muda da espécie a ser definida por DPAADDEPAVE, com DAP (diâmetro à altura do peito) de $0,07 \mathrm{~m}$ conforme demais especificações previstas no item 2.4 , além da entrega de mudas arbóreas e protetores metálicos em quantidade em dobro das previstas para compensaçăo pelo transplante mal sucedido, nos termos do item 2.4 .

3.3. Se ficar constatado que o espécime a ser preservado sucumbiu por descumprimento das normas técnicas habituais utilizadas na preservação de vegetação arbórea ou por não observar os cuidados descritos no item 3.2 deverá ser compensado com o plantio no mesmo local de uma muda e da entrega de mudas arbóreas e protetores metálicos, nos termos do item 2.4 .

3.4. A manutenção e conservação dos exemplares que vierem a serem substituído(s) deverão ser efetuadas pelo prazo de 12 (doze) meses, a partir da data da constatação da substituição.

\section{CLÁUSULA QUARTA - DO PLANTIO}

4.1. PLANTAR 14 (catorze) mudas de espécies nativas do Estado de São Paulo, padrāo DEPAVE, com DAP $5,0 \mathrm{~cm}$ e respectivos tutores, no local.

4.2. Em caso de motivo de força maior, o prazo para plantio poderá ser prorrogado, mediante pedido justificado e acompanhado das informações que inviabilizaram o cumprimento da obrigação nó prazo acordado.

4.3. SIURB deverá promover a conservação e manutenção dos espécimes plantados, pelo prazo de 6 (seis) meses, efetuando a devida substituiçăo, na hipótese de morte ou ocorrência de qualquer fato que comprometa a sua șobrevivência, mediante orientação do DPAAVDEPAVE e de acordo com as especificações para plantio.

4.4. As mudas nativas para o plantio interno devem ser escolhidas entre as listadas, em anexo, com altura mínima de 2,50 metros, sendo no mínimo 1,80 metros do colo à primeira bifurcação.

4.5. SIURB deverá comunicar por carta protocolada, acompanhada dos documentos 
comprovantes do técnico responsável especificados acima, o início dos procedimentos indicados para o devido acompanhamento por técnicos do DPAA/DEPAVE, sendo que todos os procedimentos deverăo ser documentados fotograficamente.

\section{CLÁUSULA QUINTA - DOS PRAZOS}

5.1. A autorização para o manejo dos exemplares descritos na cláusula primeira terá validade de 06 (seis) meses, a contar da publicação do extrato do TCA no DOC.

5.2. O plantio interno deverá ser realizado até o final das obras e antes dà obtenção do Auto de Conclusăo.

5.3. O prazo previsto no item 5.1 poderá ser prorrogado mediante pedido escrito, protocolado antes do encerramento do prazo inicial, dirigido a Divisão Técnica de Proteção e Avaliação Ambiental, do Departamento de Parques e Áreas Verdes DEPAVE/DPAA, contendo justificativa das razōes que inviabilizaram o cumprimento da obrigação no prazo estabelecido, acompanhada de documentos que comprove o alegado.

5.4. A SIURB ficará responsável pela conservação e manutenção dos exemplares pelo prazo de 06 (seis) meses:

- transplantados, efetuando a devida compensação nos termos do item 2.4 , no caso de morte de qualquer exemplar;

- plantados, efetuando a devida substituição, na hipótese de morte ou ocorrência de qualquer fato que comprometa a sua sobrevivência, mediante orientação do Departamento de Parques e Áreas Verdes - DEPAVE, e de acordo com as especificações para plantio e;

- substituídos, a partir da data da constatação da substituição.

\section{CLÁUSULA SEXTA - DAS COMUNICAÇÕES}

6.1. A SVMA deverá ser cientificada do início de cada uma das atividades descritas na cláusula primeira, mediante protocolo de comunicação escrita, endereçada à Câmara de Compensação Ambiental, acompanhada da comprovação da anotaçăo de responsabilidade técnica:

6.2. A SIURB informará à SVMA o término de cada etapa deste compromisso 
mediante protocolo de comunicação escrita, endereçada à Câmara de Compensaçăo Ambiental, instruida com relatório sucinto e fotografias das atividades efetivadas.

6.3. A SIURB indicará responsável para acompanhamento dos compromissos junto à Câmara de Compensação Ambiental.

\section{CLÁUSULA SÉTIMA - DA FISCALIZAÇÃO DAS OBRIGAÇÕES ASSUMIDAS}

7.1. Caberá à SVMA, através da Câmara de Compensação Ambiental, designar técnico para o acompanhamento e vistoria dos trabalhos autorizados.

7.2. Após a comunicação do término de cada uma das atividades descritas na cláusula primeira, a Câmara de Compensaçăo Ambiental solicitará ao Departamento competente a realização de vistoria e manifestação conclusiva sobre conformidade dos procedimentos com as obrigações assumidas no presente termo.

7.3. A vistoria será documentada por meio de laudo técnico circunstanciado, elaborado por técnico de SVMA, facultando-se à SIURB indicar assistente(s) técnico para acompanhamento dos trabalhos.

7.3.1. Havendo conclusão uniforme entre o técnico designado por SVMA e o(s) assistente(s) da SIURB, poderão lavrar laudo comum, por ambos assinado.

7.3.2. Se houver divergência entre o técnico e o(s) assistente(s), cada qual escreverá laudo em separado, dando as razőes em que se fundam.

7.4. Constatado pela Câmara de Compensação Ambiental o integral cumprimento dos compromissos fixados no presente instrumento, este órgão emitirá Termo de Recebimento das obrigações assumidas.

7.5. Em caso de descumprimento de quaisquer dos compromissos assumidos no presente instrumento e respectivos anexos; SVMA comunicará os fatos ao $\mathrm{Sr}$. SECRETÁRIO de SIURB para conhecimento e deliberação acerca das medidas reparatórias a serem adotadas por SIURB, sem prejuízo da apuração administrativa da responsabilidade pelo descumprimento.

\section{CLÁUSULA OITAVA - DOS ANEXOS}

8.1. Integram o presente instrumento:

- Parecer Técnico DPAA 057/2009.

- Despacho autorizatório. 
E, por estarem assim concordes, firmam o presente instrumento em 4 (quatro) vias de igual teor e forma, na presença de testemunhas, que também o subscrevem.

$$
\text { SãoPaulo, ( de } \mu 1, J \text { de } 2009 .
$$
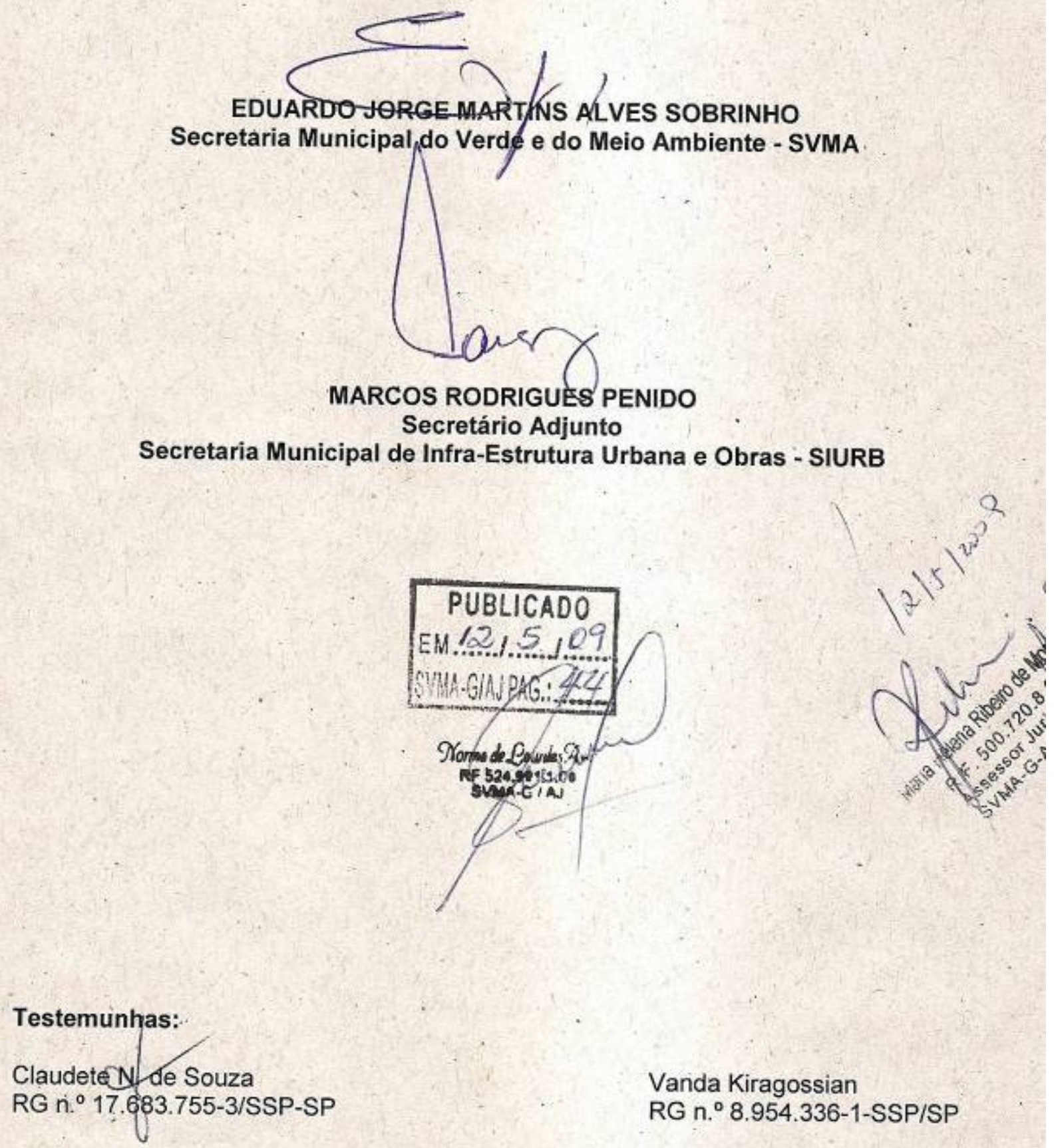
8.2. ANEXO B - Boletins da Sondagem 


\section{DETERMINAÇÃO DE ESPESSURA DE CAMADA - FURO: ST- 01}

\begin{tabular}{|c|c|c|c|c|}
\hline \multicolumn{3}{|c|}{$\begin{array}{l}\text { CTH - USP } \\
\text { Local: Estacionamento } \\
\text { Coordenadas: 23K N } 7394076 \text { E } 0323815\end{array}$} & \multicolumn{2}{|c|}{$\begin{array}{l}\text { Data de início: 06/03/2009 } \\
\text { Data de término: 06/03/2009 }\end{array}$} \\
\hline \multicolumn{2}{|c|}{$\begin{array}{l}\text { Profundidade } \\
\qquad(\mathrm{m})\end{array}$} & \multirow{2}{*}{$\begin{array}{l}\text { Amostra } \\
\left(\mathrm{n}^{\circ}\right)\end{array}$} & \multirow{2}{*}{ Descrição do material } & \multirow{2}{*}{$\begin{array}{l}\text { Motivo da } \\
\text { Paralisação }\end{array}$} \\
\hline Início & Término & & & \\
\hline 0,00 & 0,07 & & Vegetação & \\
\hline 0,07 & 0,32 & & Solo Brita & \\
\hline 0,32 & 0,56 & AM - 03 & $\begin{array}{l}\text { Areia argilo siltosa } \\
\text { Cor: Cinza Escura }\end{array}$ & \\
\hline 0,56 & 0,86 & & $\begin{array}{c}\text { Argila Siltosa Pouca } \\
\text { Arenosa } \\
\text { Cor: Cinza Amarelado }\end{array}$ & \\
\hline 0,86 & 1,50 & & $\begin{array}{c}\text { Silte Argiloso } \\
\text { Cor: Cinza Escura } \\
\text { N.A: Seco }\end{array}$ & $\begin{array}{l}\text { Atingiu a } \\
\text { profundidade } \\
\text { programada }\end{array}$ \\
\hline
\end{tabular}




\begin{tabular}{|c|c|c|c|c|c|}
\hline \multicolumn{6}{|c|}{ DETERMINAÇÃO DE ESPESSURA DE CAMADA - FURO: ST- 02} \\
\hline \multicolumn{4}{|c|}{$\begin{array}{l}\text { CTH - USP } \\
\text { Local: Estacionamento } \\
\text { Coordenadas: } 23 \text { K N } 7394067 \text { E } 0323794\end{array}$} & \multicolumn{2}{|c|}{$\begin{array}{l}\text { Data de início: 06/03/2009 } \\
\text { Data de término: 06/03/2009 }\end{array}$} \\
\hline \multicolumn{2}{|c|}{$\begin{array}{l}\text { Profundidade } \\
\text { (m) }\end{array}$} & \multirow{2}{*}{$\begin{array}{l}\text { Amostra } \\
\quad(n \div)\end{array}$} & \multirow{2}{*}{\multicolumn{2}{|c|}{ Descrição do material }} & \multirow{2}{*}{$\begin{array}{l}\text { Motivo da } \\
\text { Paralisação }\end{array}$} \\
\hline Início & Término & & & & \\
\hline 0,00 & 0,08 & & & Vegetação & \\
\hline 0,08 & 0,24 & & & $\begin{array}{l}\text { gila Siltosa com Entulho } \\
\text { Cor: Marrom }\end{array}$ & \\
\hline 0,24 & 0,40 & & & $\begin{array}{l}\text { Argila Siltosa Pouco } \\
\text { enosaCor: Cinza Escura }\end{array}$ & \\
\hline 0,40 & 0,62 & & & $\begin{array}{l}\text { de Média com Entulho } \\
\text { de Construção } \\
\text { Cor: Cinza Escura }\end{array}$ & \\
\hline 0,62 & 0,87 & & & $\begin{array}{l}\text { Areia Média a Grossa } \\
\text { Cor: Cinza ClaraN.A: } \\
\text { Seco }\end{array}$ & \\
\hline 0,87 & 1,50 & & & $\begin{array}{l}\text { Silte Argiloso } \\
\text { Nor: Marrom Amarelado } \\
\text { N.A: Seco }\end{array}$ & $\begin{array}{l}\text { Atingiu a } \\
\text { profundidade } \\
\text { programada }\end{array}$ \\
\hline
\end{tabular}




\begin{tabular}{|c|c|c|c|c|c|}
\hline \multicolumn{6}{|c|}{ DETERMINAÇÃO DE ESPESSURA DE CAMADA - FURO: ST- 03} \\
\hline \multicolumn{4}{|c|}{$\begin{array}{l}\text { CTH - USP } \\
\text { Local: Estacionamento } \\
\text { Coordenadas: } 23 \text { K N } 7394058 \text { E } 0323818\end{array}$} & \multicolumn{2}{|c|}{$\begin{array}{l}\text { Data de início: 06/03/2009 } \\
\text { Data de término: 06/03/2009 }\end{array}$} \\
\hline \multicolumn{2}{|c|}{$\begin{array}{l}\text { Profundidade } \\
\qquad(\mathrm{m})\end{array}$} & \multirow{2}{*}{$\begin{array}{l}\text { Amostra } \\
\quad(n \div)\end{array}$} & \multirow{2}{*}{\multicolumn{2}{|c|}{ Descrição do material }} & \multirow{2}{*}{$\begin{array}{l}\text { Motivo da } \\
\text { Paralisação }\end{array}$} \\
\hline Início & Término & & & & \\
\hline 0,00 & 0,11 & & & Vegetação & \\
\hline 0,11 & 0,28 & & & $\begin{array}{l}\text { Argila Pouca Siltosa } \\
\text { Pouca Arenosa } \\
\text { Cor: Marrom Escuro }\end{array}$ & \\
\hline 0,28 & 0,40 & AM - 01 & & $\begin{array}{l}\text { Argila areno siltosa } \\
\text { : Marrom Avermelhada }\end{array}$ & \\
\hline 0,40 & 0,77 & AM - 02 & & $\begin{array}{l}\text { eia média com Entulho } \\
\text { de Construção } \\
\text { Cor: Cinza clara }\end{array}$ & \\
\hline 0,77 & 1,50 & & & $\begin{array}{c}\text { Argila Arenosa } \\
\text { Cor: Cinza Escura } \\
\text { N.A: Seco }\end{array}$ & $\begin{array}{l}\text { Atingiu a } \\
\text { profundidade } \\
\text { programada }\end{array}$ \\
\hline
\end{tabular}


8.3. ANEXO C - Perfis Geotécnicos e Classificação MCT 


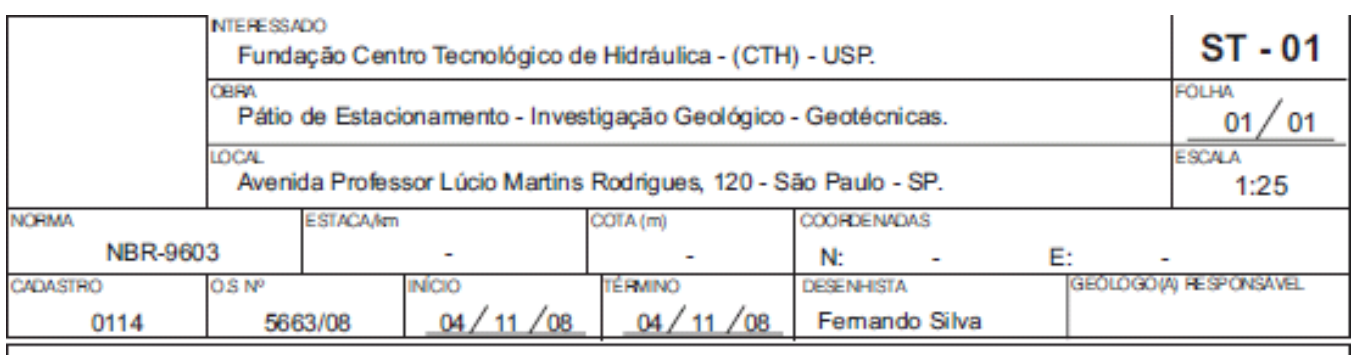

PERFIL GEOTÉCNICO INDIVIDUAL - SONDAGEM A TRADO

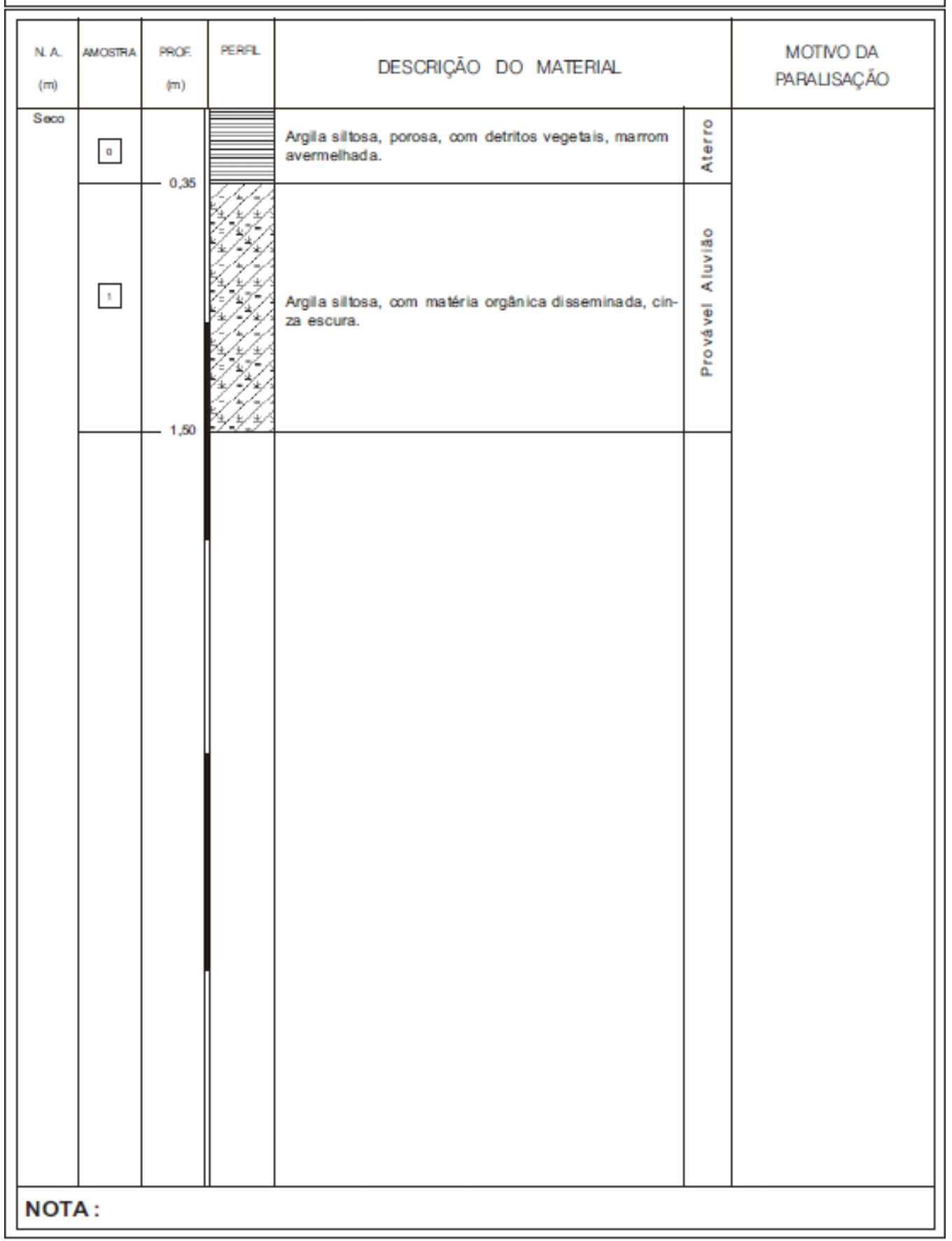




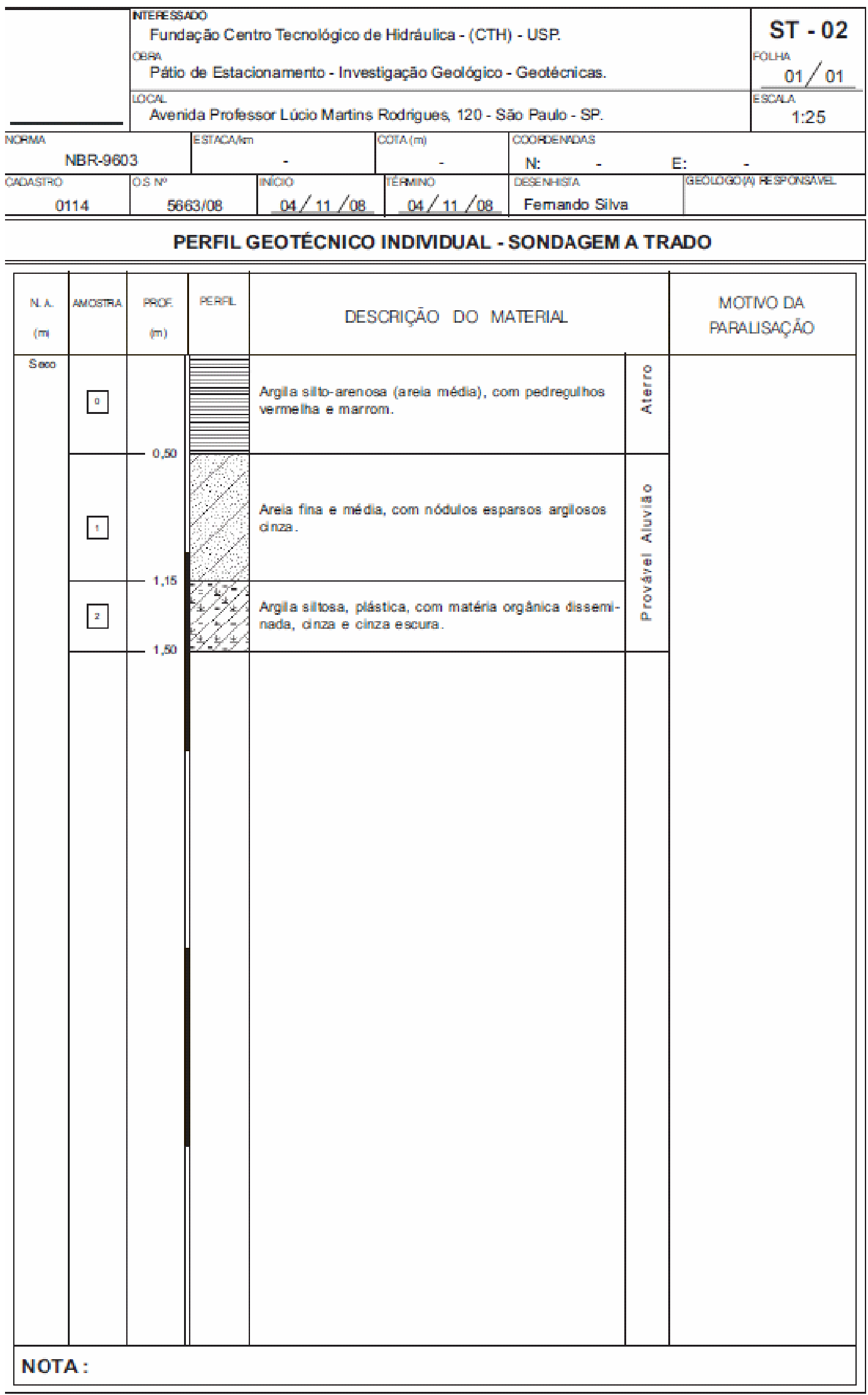




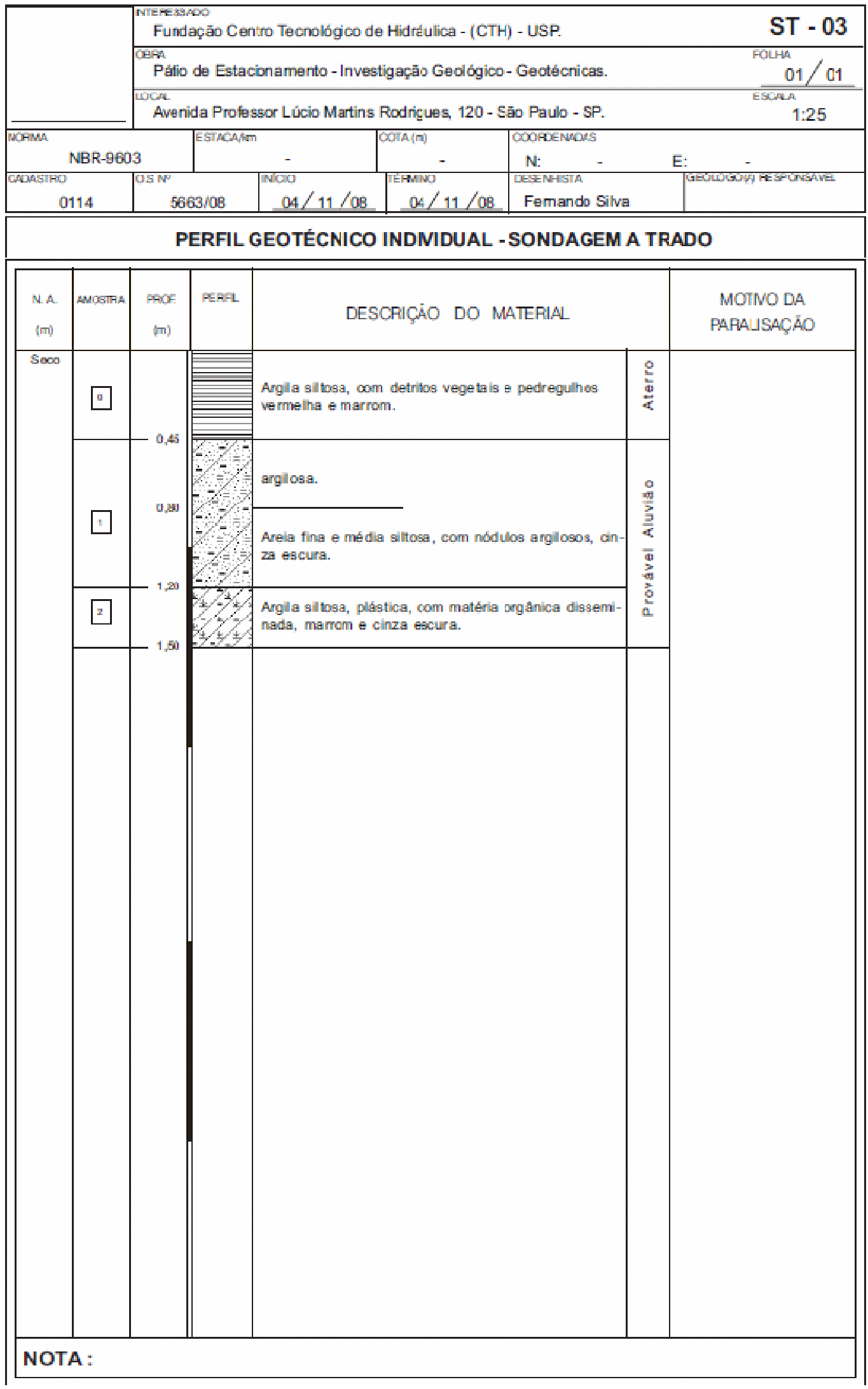




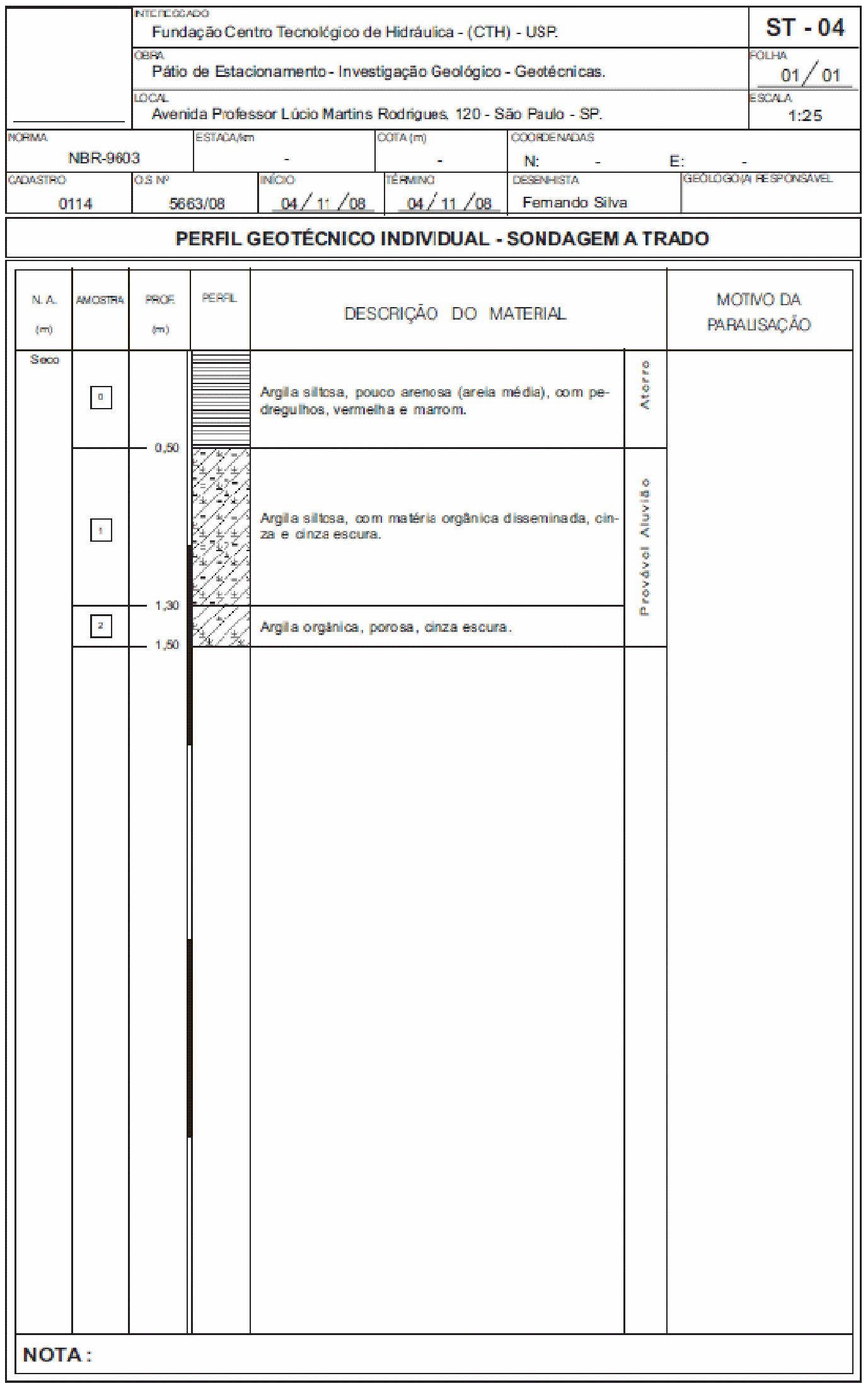




\begin{tabular}{|c|c|c|c|c|c|c|}
\hline & \multicolumn{5}{|c|}{ JTEEESRDO } & \multirow{2}{*}{$\begin{array}{c}\text { ST - } 05 \\
\text { FOLHA } \\
01 / 01 \\
\end{array}$} \\
\hline & \multicolumn{4}{|c|}{ Páfio de Estacionamento - Investigaçăo Geológito - Geotécricas. } & & \\
\hline & \multicolumn{4}{|c|}{$\begin{array}{l}\text { Doch } \\
\text { Avenida Professor Lúcio Martins Rodrigues, } 120 \text { - São Paulo - SP. }\end{array}$} & & $1: 25$ \\
\hline WOMAB & |ESTRC & & GOTA(m) & COOFLENOAS & & \\
\hline \multirow{2}{*}{ NBR-9603 } & & - & - & $\mathrm{N}: \quad-$ & \multirow{2}{*}{\multicolumn{2}{|c|}{ E: $\quad-$}} \\
\hline & IOS $\mathbb{N}^{\circ}$ & NigO & TEEMINOY & LESEMHSTIA & & \\
\hline 0114 & $5663 / 08$ & $04 / 11 / 08$ & $04 / 11 / 08$ & Femando Silva & & \\
\hline
\end{tabular}

PERFIL GEOTÉCNICO INDIVIDUAL - SONDAGEM A TRADO

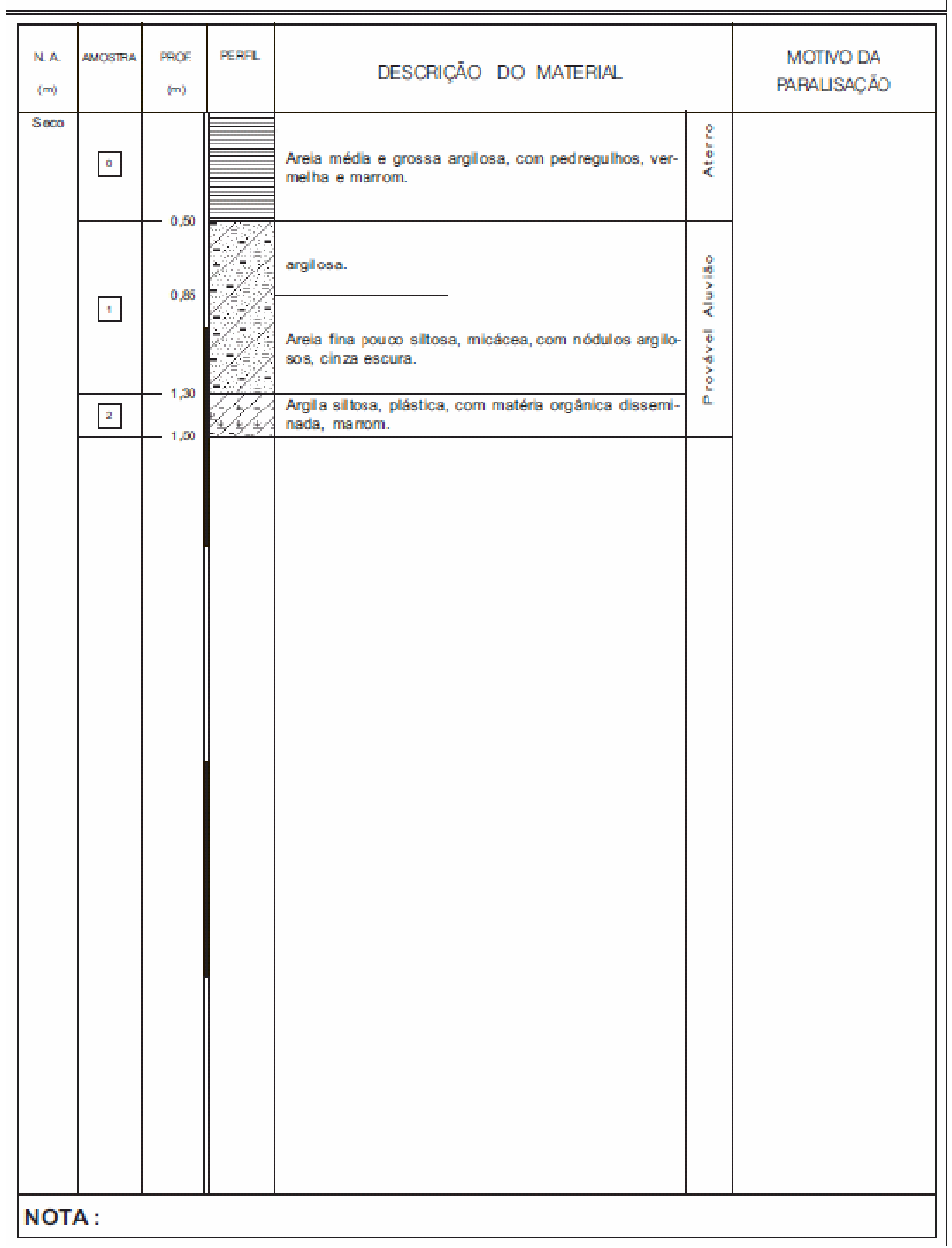


MCT - FURO 1
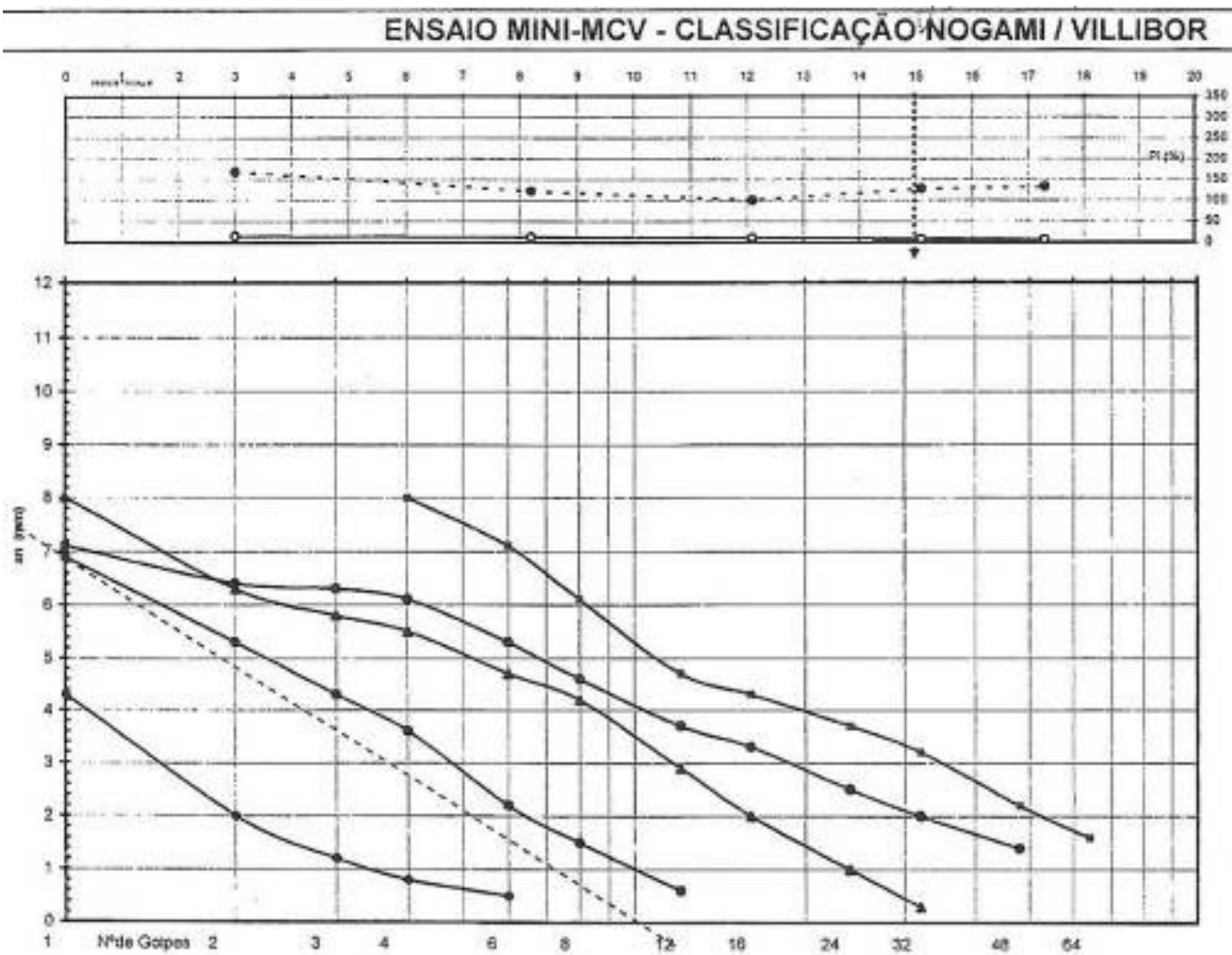

\begin{tabular}{|c|c|c|}
\hline mev & $\mathrm{Pi} \%$ & $h(\%)$ \\
\hline 3.0 & 169,0 & 14,6 \\
\hline 8.2 & 122,0 & 11,9 \\
\hline 12,1 & 99,0 & 10,2 \\
\hline 15,1 & 128,0 & 8.2 \\
\hline 17,3 & 133,0 & 6,3 \\
\hline
\end{tabular}
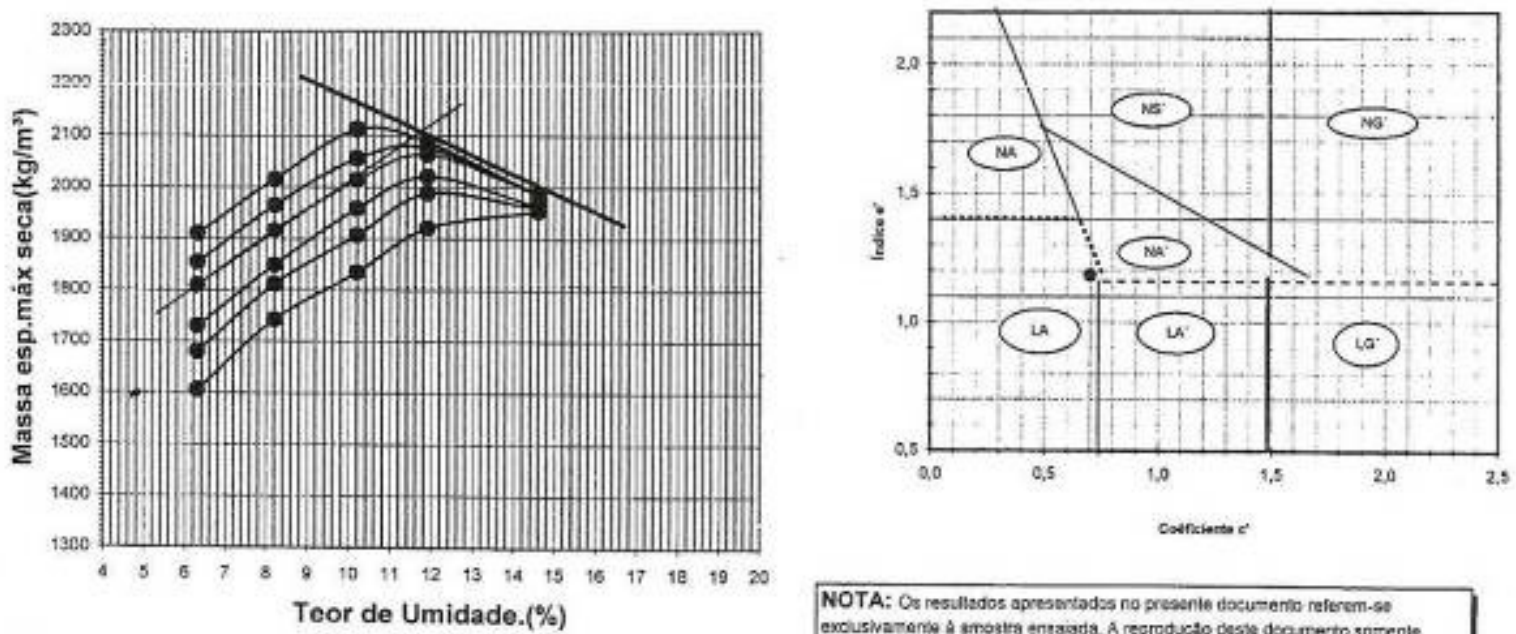

NOTA: Or resultados apresontadas no presenie docusentio reforem-so exolusivamanto A smostra entrada. A reproducto deste dsomerto somente

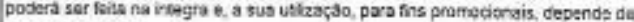
aprovazàa prêvial

\begin{tabular}{|cc}
\hline $\mathrm{Pi}^{\mathrm{i}}$ & $=125,0$ \\
\hline $\mathrm{d}^{*}$ & $=52,8$ \\
\hline $\mathrm{c}^{\prime}$ & $=0,70$ \\
\hline $\mathrm{e}^{\prime}$ & $=1,18$ \\
\hline Classif. $^{\prime}$ & LANA \\
\hline
\end{tabular}




\section{MCT - FURO 2}
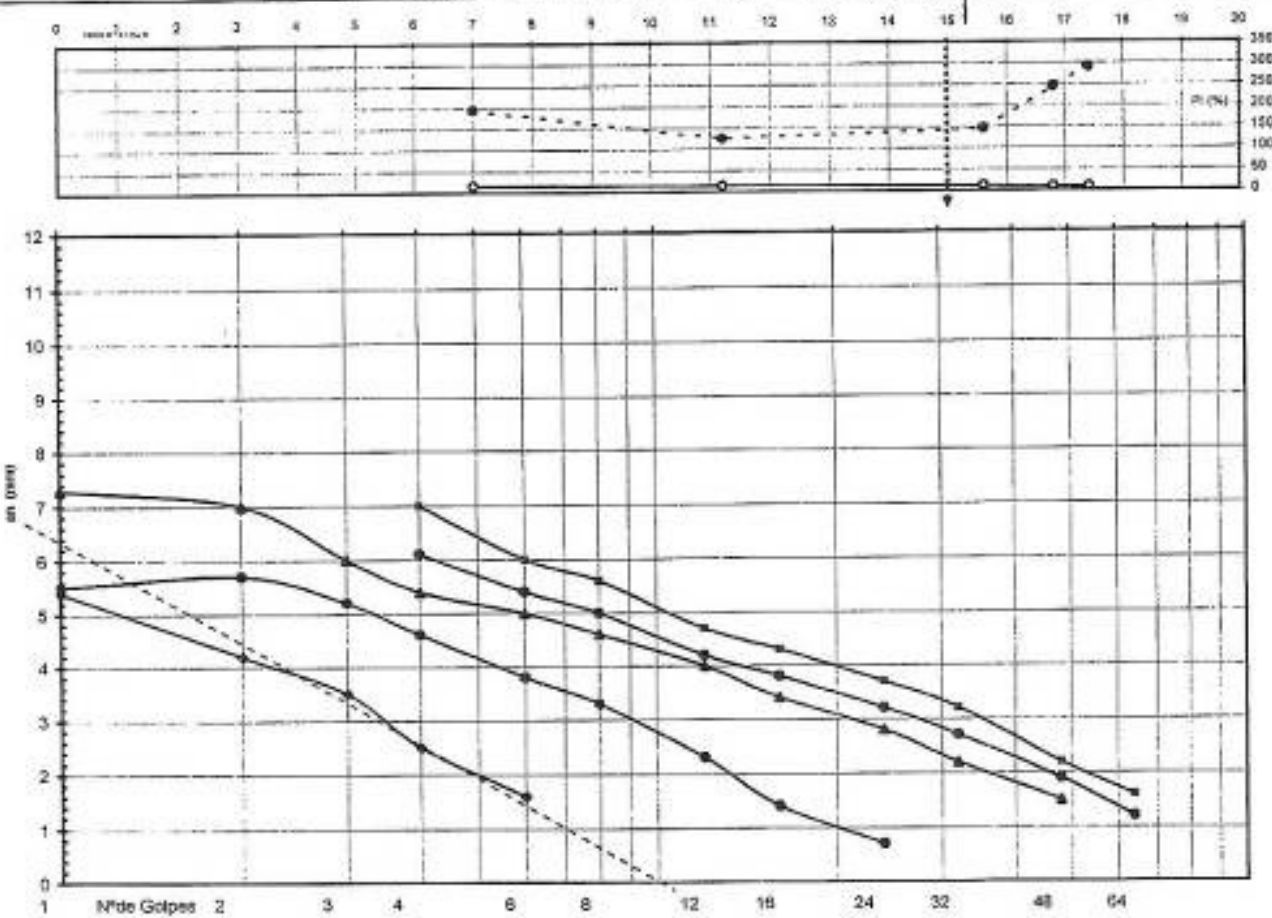

\begin{tabular}{|c|c|c|}
\hline $\mathrm{mcr}$ & $P i \%$ & $\mathrm{~h}<\%$ \\
\hline 7,0 & 194,0 & 15,4 \\
\hline 11,2 & 125,0 & 13,7 \\
\hline 15,6 & 146,0 & 11.4 \\
\hline 16,8 & 244,0 & 9,2 \\
\hline 17,4 & 280,0 & 7,8 \\
\hline
\end{tabular}
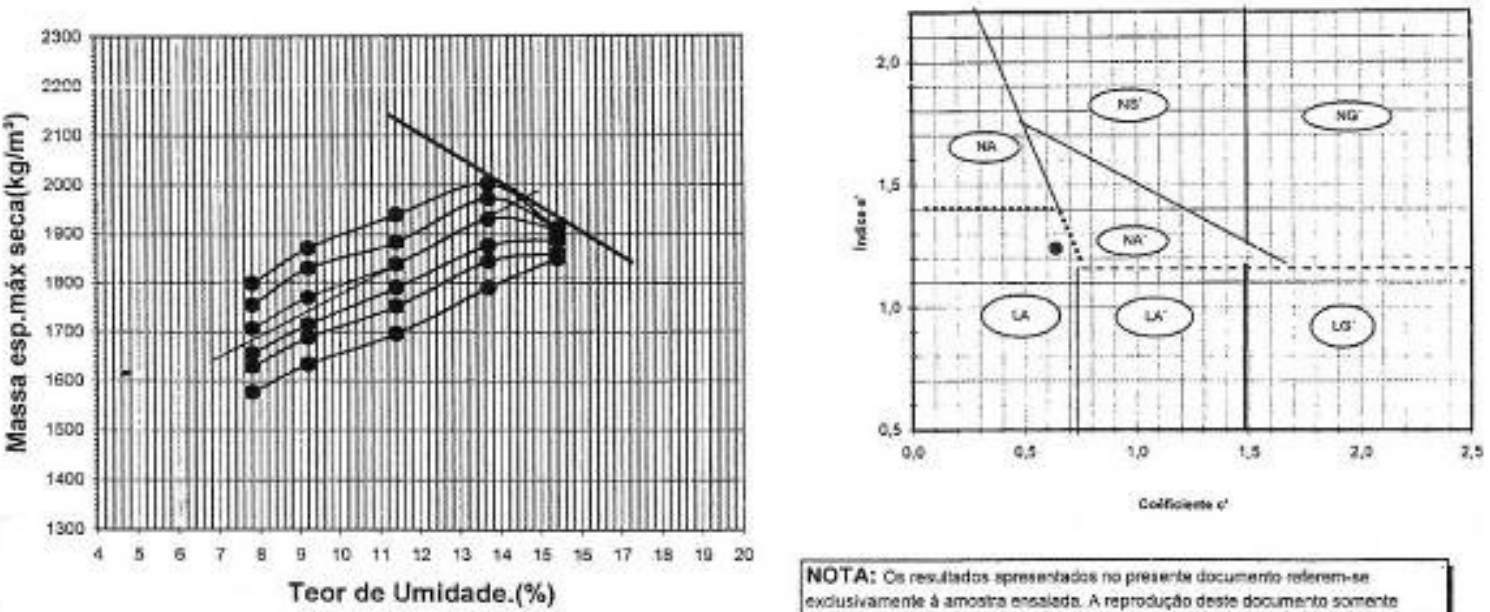

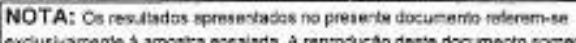

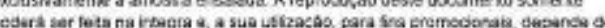
agrovacito grtwia

\begin{tabular}{|cr|}
\hline$P I$ & $=140, C$ \\
\hline$d^{\prime \prime}$ & $=37,6$ \\
\hline$c^{\prime}$ & $=0,64$ \\
\hline$e^{\prime}$ & $=1,24$ \\
\hline Classif, $=$ & $L$ \\
\hline
\end{tabular}


MCT - FURO 3

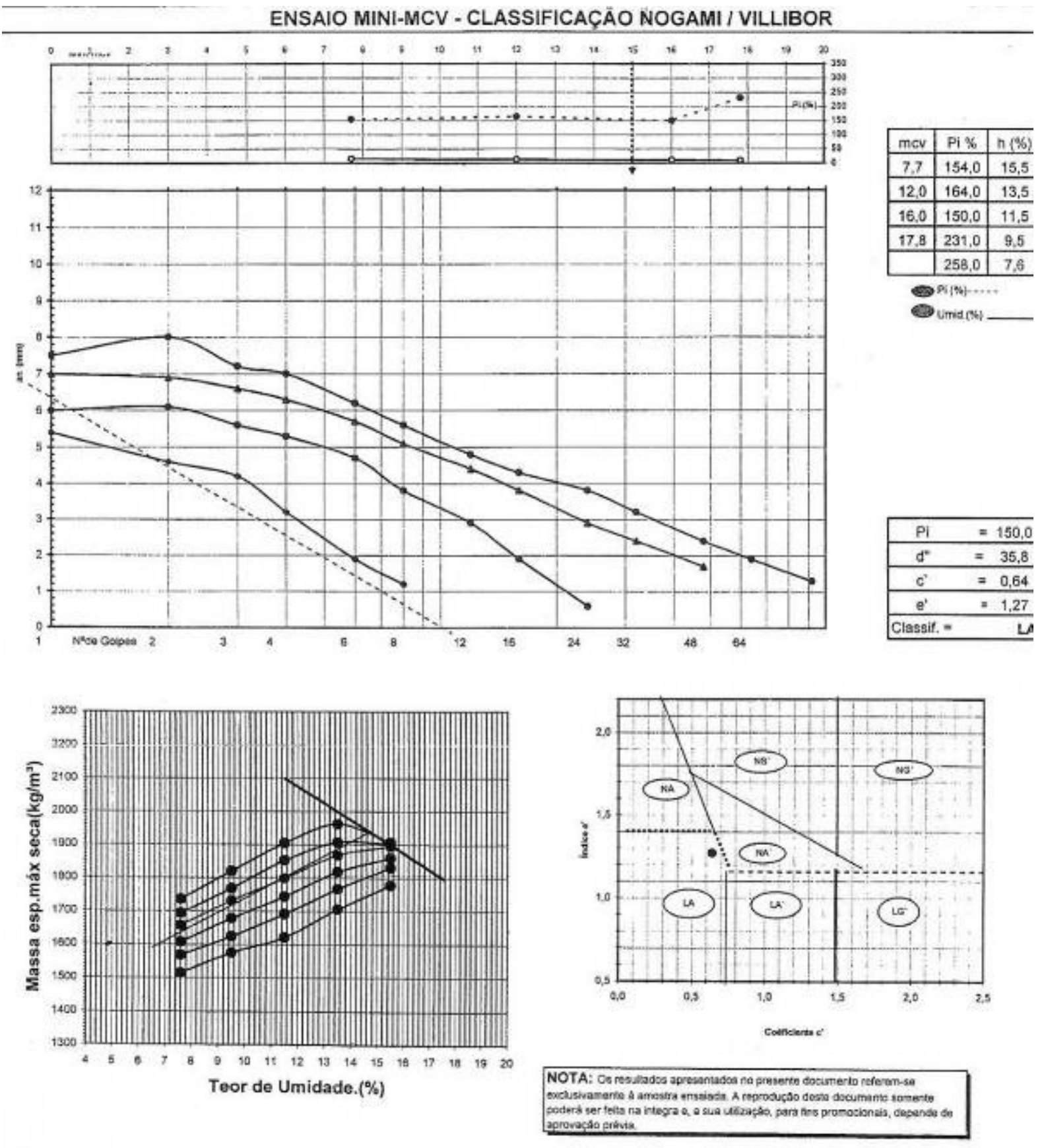




\section{MCT - FURO 4}

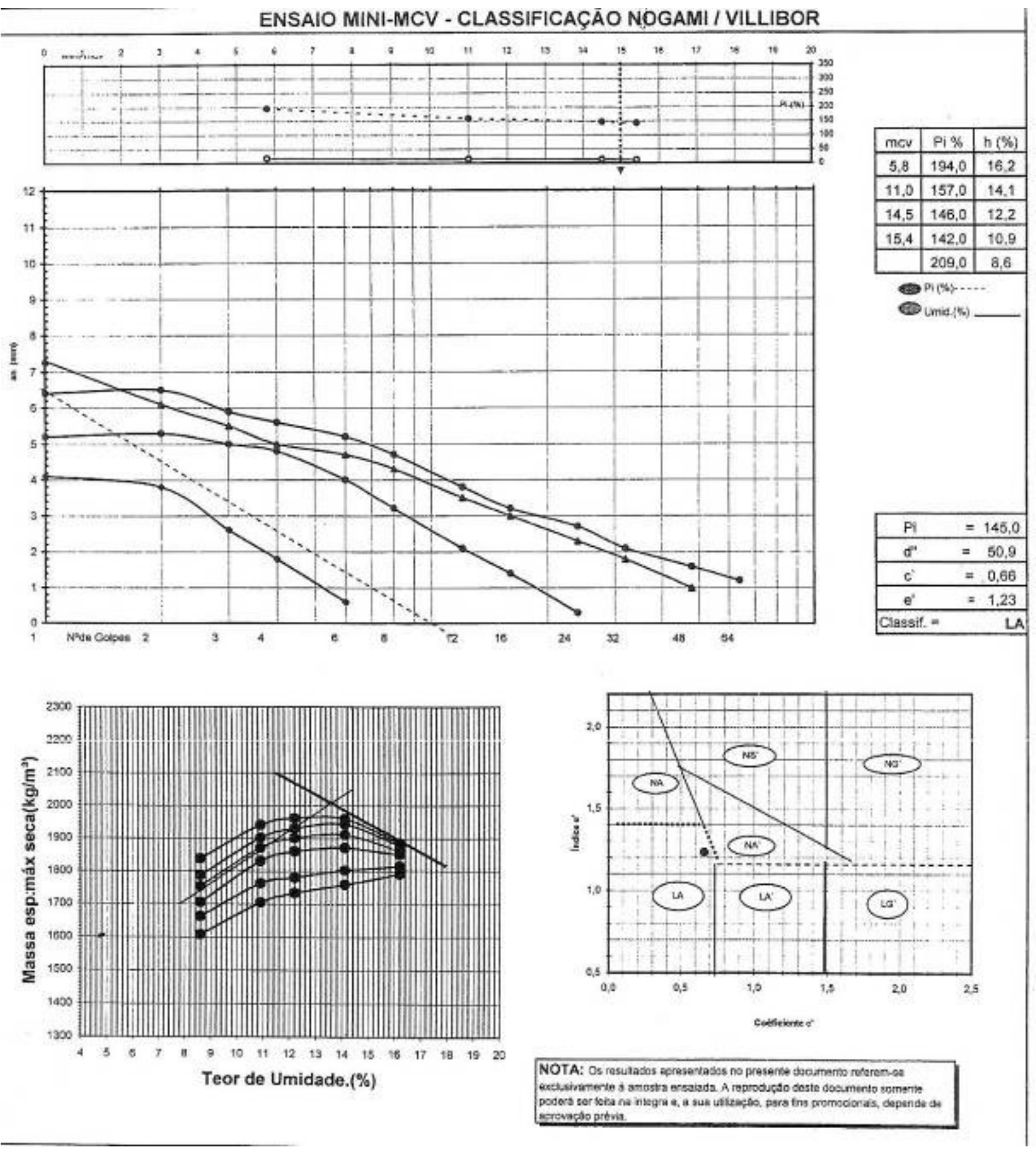




\section{MCT - FURO 5}

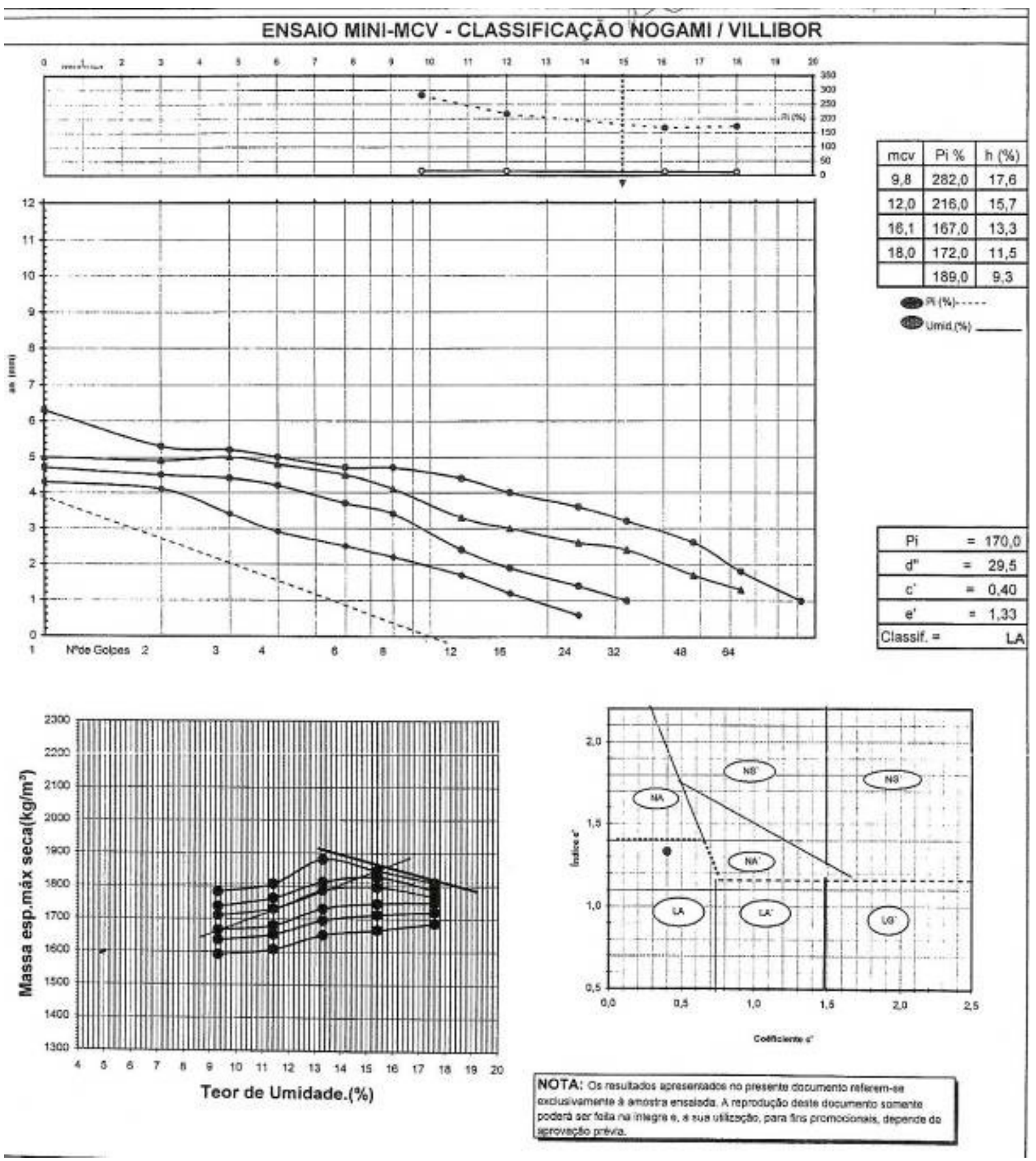


187

8.4. ANEXO D - Dosagem do CPA 


\section{GRUPO CCR - ENGELOG}

\section{USINA: DIVERSAS}

DOSAGEM DE CAMADA POROSA DE ATRITO ( CPA )

CPA - FAIXA ARIZONA

\section{Dosagem: CCR-BRI-CPA AZN-018/2009-M75 de 15/03/2009}

ESPECIFICAÇĂOO TÉCNICA PARA PROJETO DE MISTURAS ASFÁLTICAS A QUENTE EN-000/00-0000.00-GER-A1-PV/ET-E-001-R7

AGREGADOS : PEDREIRA BARUERI

ESPECIFICAÇÃO ARIZONA

A ESPESSURA DA CAMADA COMPACTADA NA PISTA DEVE SER DE 3 A $5 \mathrm{~cm}$. NÃO SERÃO ADMITIDAS ESPESSURAS FORA DESTE INTERVALO.

\begin{tabular}{|c|c|c|c|}
\hline \multicolumn{3}{|c|}{ VALORES ENCONTRADOS PARA TEOR OTIMO EM PESO DE ASFALTO ADICIONADO (AASHTO R-35) } & $4,5 \%$ \\
\hline \multicolumn{3}{|c|}{ COMPOSIÇÃO DA MISTURA SECA } & CAP - FLEXPAVE 65/90 \\
\hline BARUERI & GRANILHA (10mm) & $93,1 \%$ & $88,9 \%$ \\
\hline BARUERI & AREIA ARTIFICIAL & $5,0 \%$ & $4,8 \%$ \\
\hline DIVERSOS & CAL CH I & $1,5 \%$ & $1,4 \%$ \\
\hline DIVERSOS & Fibra Viatop & $0,4 \%$ & $0,4 \%$ \\
\hline \multicolumn{2}{|c|}{$\begin{array}{r}\text { TOTAL } \\
\end{array}$} & $100,0 \%$ & $4,5 \%$ \\
\hline \multicolumn{3}{|c|}{ TOTAL GERAL } & $100,0 \%$ \\
\hline
\end{tabular}

AS PORCENTAGENS DE AGREGADOS INDICADAS SAO VALIDAS PARA AS GRANULOMETRIAS DOS AGREGADOS UTILIZADOS PARA A ELABORAÇAO DA DOSAGEM, E DEVEM SER AJUSTADAS EM FUNÇAO DAS GRANULOMETRIAS DOS AGREGADOS DISPONIVEIS NO ESTOQUE EM CADA DIA DE PRODUÇAO DA USINA, PARA MANTER A GRANULOMETRIA RESULTANTE FIELMENTE NA FAIXA DE TRABALHO DEFINIDA. 


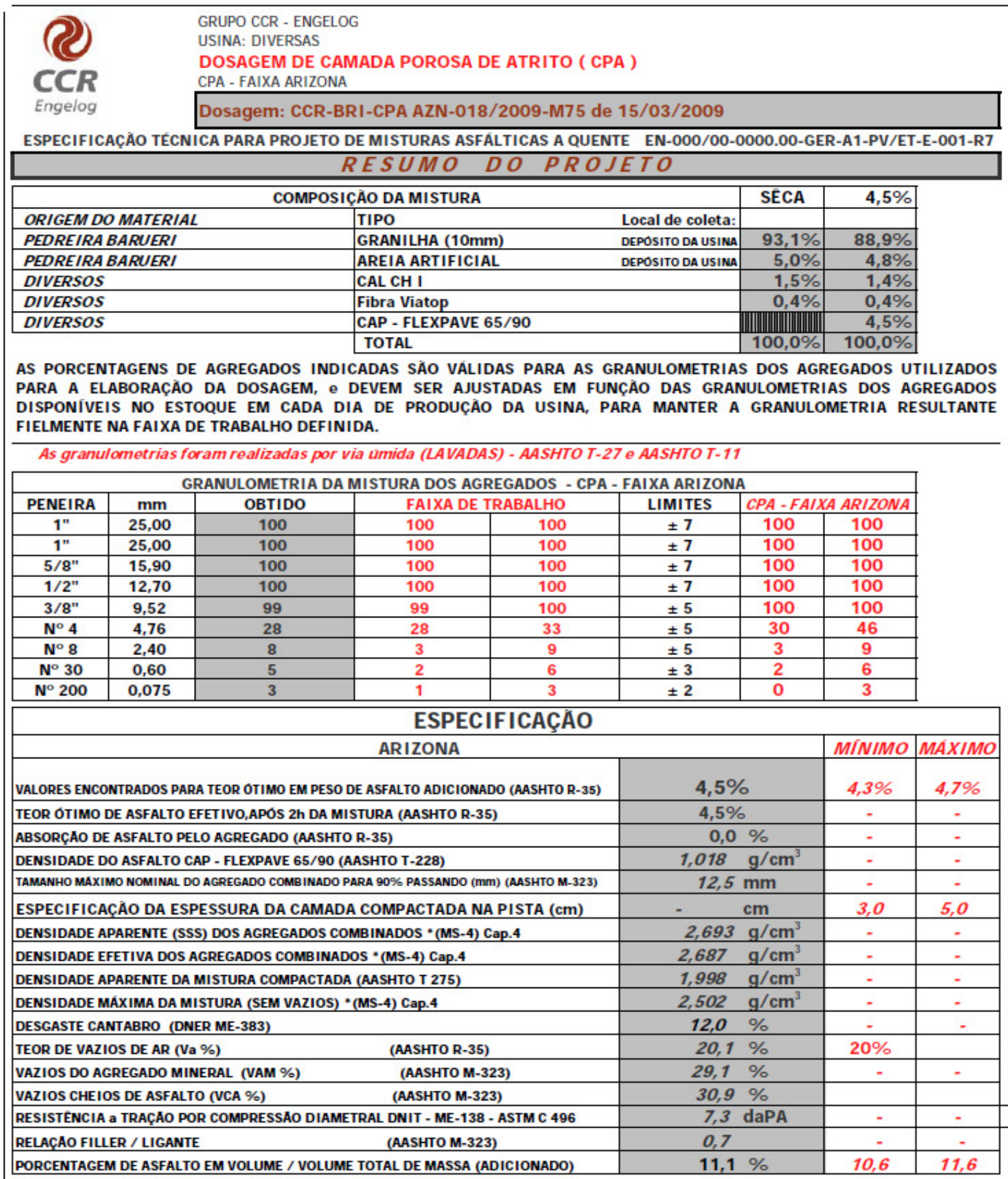

Os agregados foram fracionados ( Segundo as porcentagens definidas), nas peneiras: $-1 / 2^{\prime \prime}-3 / 8^{\prime \prime}-N^{\circ} 4-N^{\circ} 8--$, para a preparaçào individual dos corpos de prova com altura de $6,35 \pm 0,13 \mathrm{~cm}$.

A compactaçào, com 75 golpes por face do Corpo de Prova, bem como a Densidade Maxima da Mistura, foram executadas 2 horas apos a mistura, conforme AASHTO R-30.

AS TEMPERATURAS DE MISTURA Y COMPACTAÇĀO NA PISTA DEVEM SER INFORMADAS PELO FORNECEDOR DO LIGANTE MODIFICADO EM SEU CERTIFICADO QUE ACOMPANHA O PRODUTO.

${ }^{*}($ MS-4) $=$ INSTITUTO DE ASFALTO - MANUAL DE ASFALTO - SÉRIE N 4 - EDIÇAO 1989 ( Versáo em português 2001 - Petrobras ) 
GRUPO CCR - ENGELOG

DOSAGEM DE CAMADA POROSA DE ATRITO ( CPA)

USINA: DIVERSAS

Dosagem: CCR-BRI-CPA AZN-018/2009-M75 de 15/03/2009 CPA - FAIXA ARIZONA

ESPECIFICAÇAO ARIZONA

C O M P O S I Ç A O G R A N U L O MÉ T R I C A

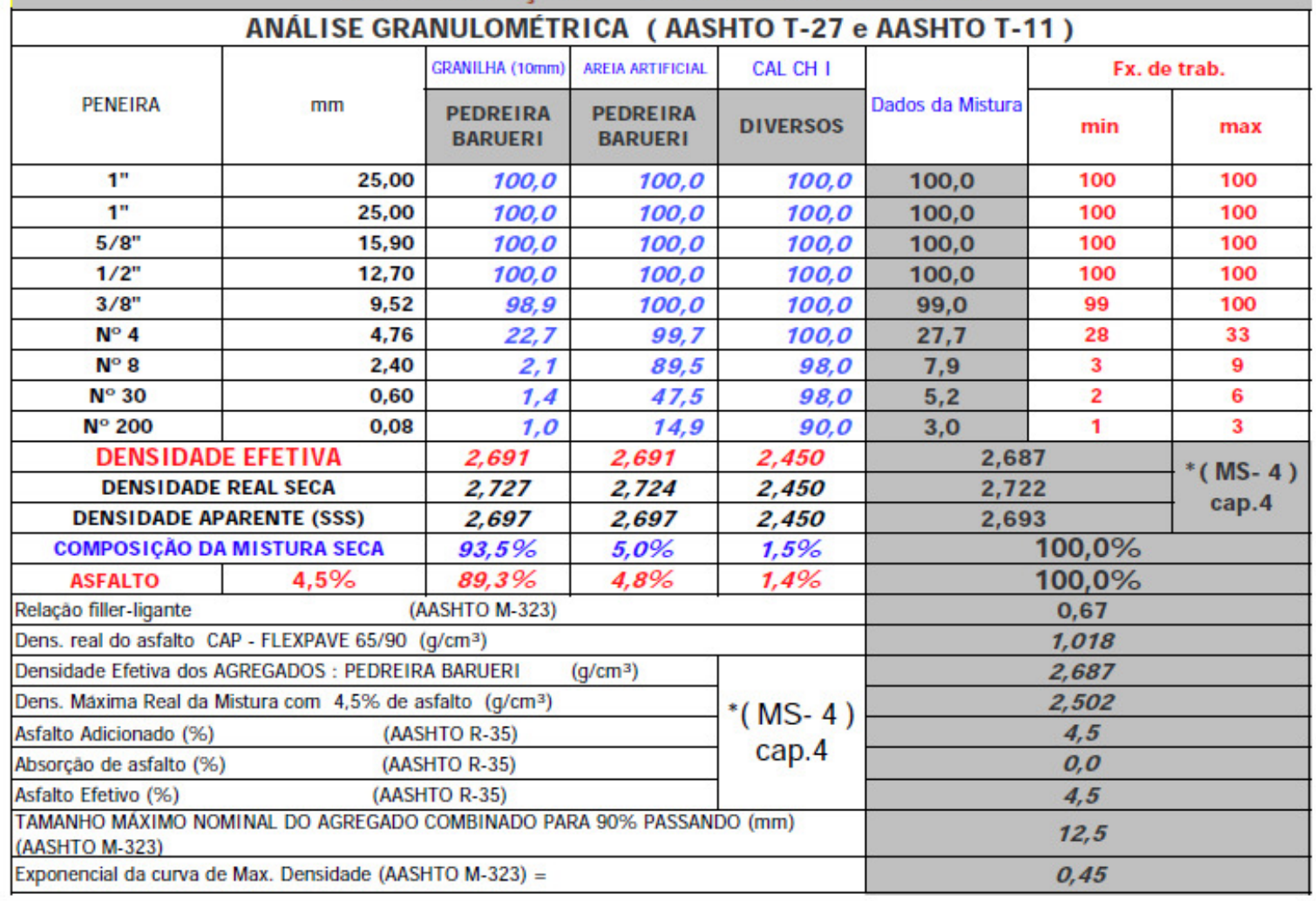

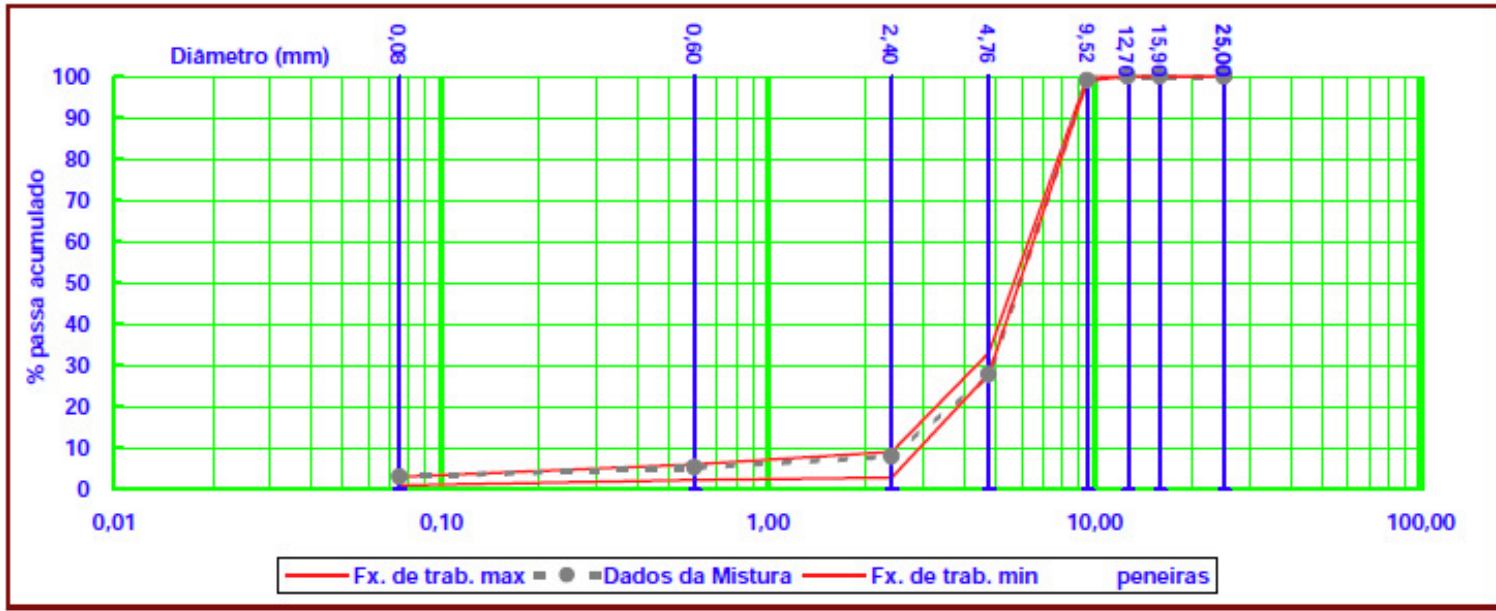

*(MS-4) = INSTITUTO DE ASFALTO - MANUAL DE ASFALTO - SÉRIE Nº 4 - EDIÇÃo 1989 (Versào em portugues 2001 - Petrobras)

As granulometrias foram realizadas por via úmida (LAVADAS)

AS PORCENTAGENS DE AGREGADOS INDICADAS SAOO VÁLIDAS PARA AS GRANULOMETRIAS DOS AGREGADOS UTILIZADOS PARA A ELABORAÇAO DA DOSAGEM, e DEVEM SER AJUSTADAS EM FUNÇĀO DAS GRANULOMETRIAS DOS AGREGADOS DISPONIVEIS NO ESTOQUE EM CADA DIA DE PRODUÇAOO DA USINA, PARA MANTER A GRANULOMETRIA RESULTANTE FIELMENTE NA FAIXA DE TRABALHO DEFINIDA. 


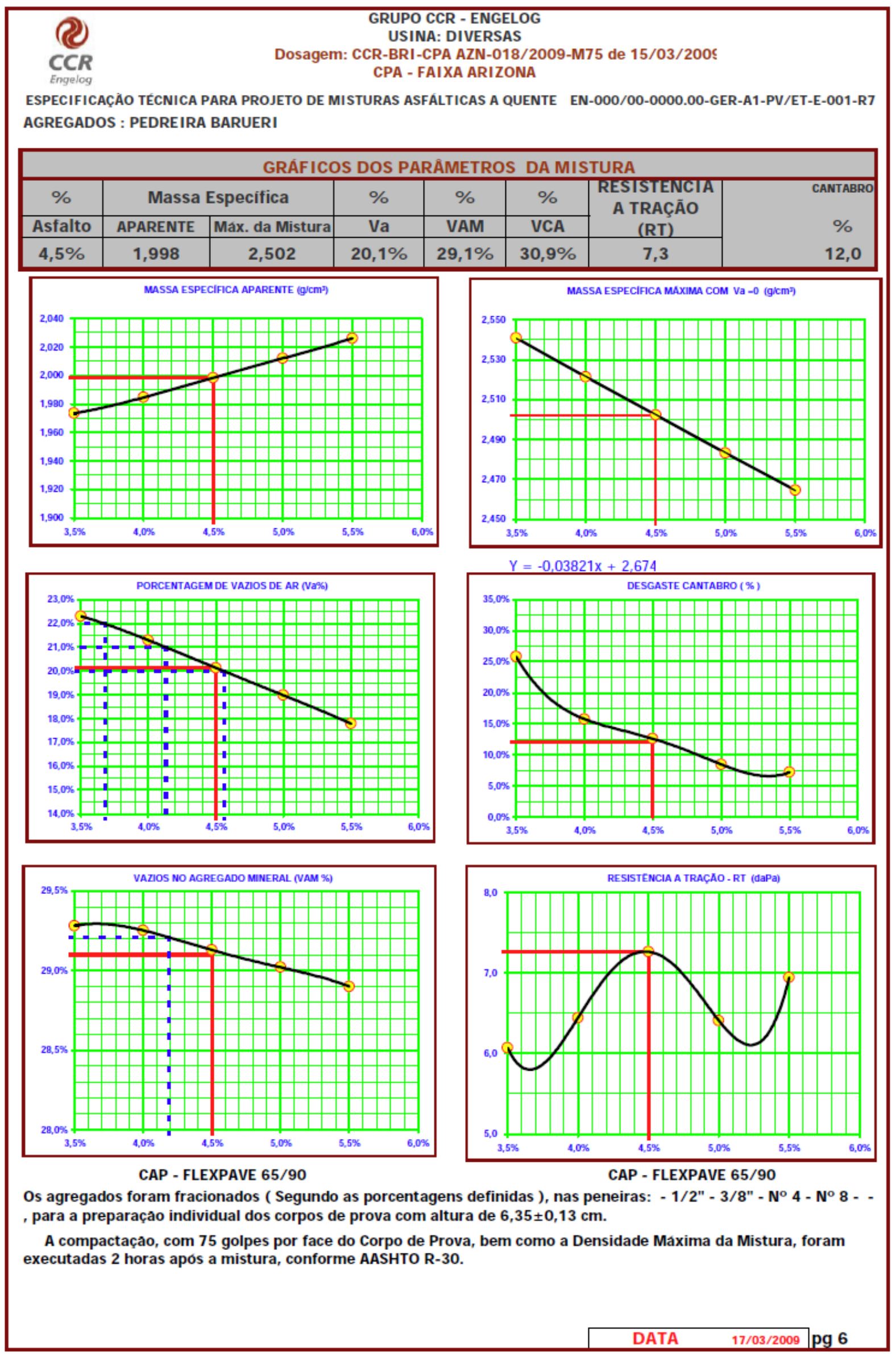

